Portland State University

PDXScholar

\title{
Metropolitan Centers: Evaluating Local Implementation of Regional Plans and Policies
}

\author{
Richard D. Margerum \\ University of Oregon \\ Keith Bartholomew \\ University of Utah \\ Rebecca Lewis \\ University of Oregon \\ Robert Parker \\ University of Oregon \\ Stephen Dobrinich \\ University of Oregon
}

Follow this and additional works at: https://pdxscholar.library.pdx.edu/trec_reports

Part of the Transportation Commons, Urban Studies Commons, and the Urban Studies and Planning Commons

Let us know how access to this document benefits you.

\section{Recommended Citation}

Richard Margerum, Rebecca Lewis, Keith Bartholomew, Robert Parker, and Stephen Dobrinich.

Metropolitan Centers: Evaluating Local Implementation of Regional Plans and Policies. NITC-RR-761. Portland, OR: Transportation Research and Education Center (TREC), 2017. https://doi.org/10.15760/ trec. 164

This Report is brought to you for free and open access. It has been accepted for inclusion in TREC Final Reports by an authorized administrator of PDXScholar. Please contact us if we can make this document more accessible: pdxscholar@pdx.edu. 


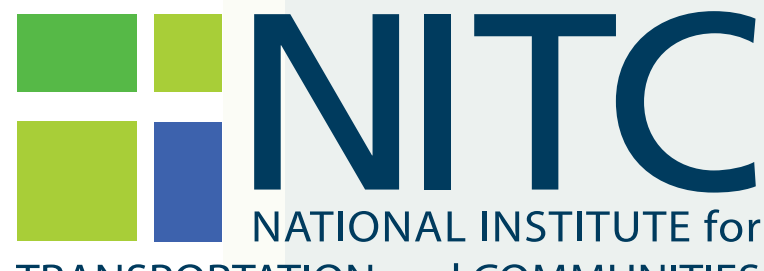

TRANSPORTATION and COMMUNITIES

FINAL REPORT

Metropolitan Centers: Evaluating Local Implementation of Regional Plans and Policies

NITCN-RR-761 — March 2017

NITC is a U.S. Department of Transportation

national university transportation center.

=IIT TREC 



\title{
METROPOLITAN CENTERS: \\ EVALUATING LOCAL IMPLEMENTATION OF REGIONAL PLANS AND POLICIES
}

Final Report

NITCN-RR-761

\author{
by \\ Richard D. Margerum \\ Rebecca Lewis \\ Keith Bartholomew \\ Robert G. Parker \\ Stephen Dobrinich \\ University of Oregon \\ University of Utah
}

for

National Institute for Transportation and Communities (NITC)

P.O. Box 751

Portland, OR 97207

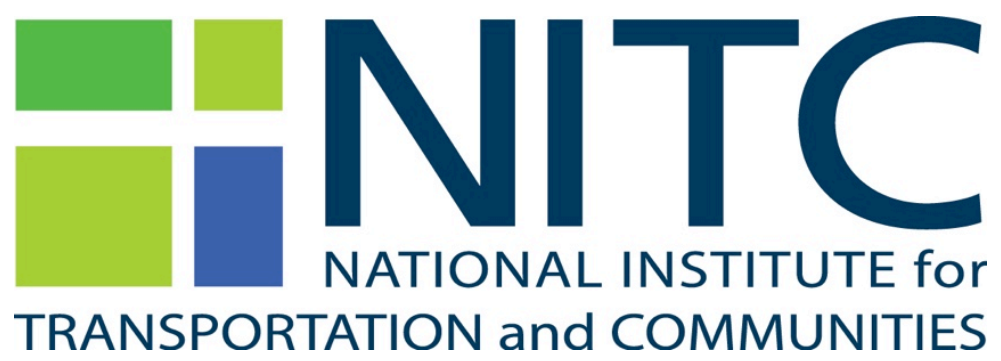

March 2017 




\begin{tabular}{|c|c|c|c|c|}
\hline \multicolumn{5}{|c|}{ Technical Report Documentation Page } \\
\hline $\begin{array}{l}\text { 1. Report No. } \\
\text { NITCN-RR-761 }\end{array}$ & \multicolumn{3}{|l|}{ 2. Government Accession No. } & 3. Recipient’s Catalog No. \\
\hline \multirow{2}{*}{\multicolumn{4}{|c|}{$\begin{array}{l}\text { 4. Title and Subtitle } \\
\text { Metropolitan Centers: } \\
\text { Evaluating local implementation of regional plans and policies }\end{array}$}} & \\
\hline & & & & 6. Performing Organization Code \\
\hline \multicolumn{3}{|l|}{$\begin{array}{l}\text { 7. Author(s) } \\
\text { Richard D. Margerum } \\
\text { Rebecca Lewis } \\
\text { Keith Bartholomew } \\
\text { Robert G. Parker } \\
\text { Stephen Dobrinich }\end{array}$} & \multicolumn{2}{|c|}{ 8. Performing Organization Report No. } \\
\hline \multirow{2}{*}{\multicolumn{3}{|c|}{$\begin{array}{l}\text { 9. Performing Organization Name and Address } \\
\text { Department of PPPM, University of Oregon } \\
\text { Eugene, OR 97403-1209 }\end{array}$}} & \multicolumn{2}{|c|}{ 10. Work Unit No. (TRAIS) } \\
\hline & & & \multicolumn{2}{|c|}{ 11. Contract or Grant No. } \\
\hline \multirow{2}{*}{\multicolumn{3}{|c|}{$\begin{array}{l}\text { 12. Sponsoring Agency Name and Address } \\
\text { National Institute for Transportation and Communities (NITC) } \\
\text { P.O. Box } 751 \\
\text { Portland, Oregon } 97207 \\
\end{array}$}} & \multicolumn{2}{|c|}{ 13. Type of Report and Period Covered } \\
\hline & & & & 14. Sponsoring Agency Code \\
\hline \multicolumn{5}{|c|}{ 15. Supplementary Notes } \\
\hline \multicolumn{5}{|c|}{$\begin{array}{l}\text { 16. Abstract } \\
\text { The Denver and Salt Lake City Metropolitan Planning Organizations (MPOs) have embarked upon regional visioning strategies that promote } \\
\text { development around higher density, mixed use centers with current or future access to transit. This study examines the programs and policies in } \\
\text { the Salt Lake City and Denver regions to examine regional vision influence on local planning and the opportunities and constraints facing } \\
\text { centers. The research team analyzed local plans over the past several decades, interviewed planners, and examined demographic, land use and } \\
\text { transportation characteristics in select centers across the region. We found that the regional vision had a moderate influence on local planning, } \\
\text { due to vague definitions and criteria. However, light rail investment and market forces have had a more substantial influence- resulting in cities } \\
\text { developing supportive transit oriented development policies. While over } 100 \text { centers have been designated, many face significant challenges to } \\
\text { support regional goals, particularly because many light rail lines were located along rail and freeway alignments. A limited number of "tipping } \\
\text { point centers" already contain the necessary elements to be successful with city and private investment. Many "greenfield centers" offer } \\
\text { significant future opportunity for development, but their suburban location and infrastructure needs present significant costs and challenges. } \\
\text { Many other "redevelopment centers" are dominated by industrial, commercial or office development, and the land use and transportation } \\
\text { patterns within these centers present substantial hurdles that may limit their potential to achieve regional goals. }\end{array}$} \\
\hline \multicolumn{2}{|c|}{$\begin{array}{l}\text { 17. Key Words } \\
\text { Regional Planning, Collaborative Growth Management, Metropolitan Centers, } \\
\text { Transit Oriented Development }\end{array}$} & \multicolumn{3}{|c|}{$\begin{array}{l}\text { 18. Distribution Statement } \\
\text { No restrictions. Copies available from NITC: } \\
\text { www.nitc.us }\end{array}$} \\
\hline $\begin{array}{l}\text { 19. Security Classification (of this report) } \\
\text { Unclassified }\end{array}$ & $\begin{array}{l}\text { 20. Security Classification (of } \mathrm{t} \\
\text { Unclassified }\end{array}$ & s page) & 21. No. of Pages & 22. Price \\
\hline
\end{tabular}





\section{ACKNOWLEDGEMENTS}

This project was funded by the National Institute for Transportation and Communities (NITC). The researchers would like to thank the staff with the Denver Regional Council of Governments and the Wasatch Front Regional Council for their assistance with data and information. The researchers would also like to thank the local government staff in both regions who participated in interviews about metropolitan centers. We would like to acknowledge research contributions from Stephen Dobrinich and Kevin Cisney, who contributed to content analysis, interviews, and writing results. We would like to acknowledge GIS assistance from Kendal Black, Taylor Eidt and Mitch Koch.

\section{DISCLAIMER}

The contents of this report reflect the views of the authors, who are solely responsible for the facts and the accuracy of the material and information presented herein. This document is disseminated under the sponsorship of the U.S. Department of Transportation University Transportation Centers Program, the University of Oregon and the University of Utah in the interest of information exchange. The U.S. Government and the University of Oregon and the University of Utah assume no liability for the contents or use thereof. The contents do not necessarily reflect the official views of the U.S. Government nor the Universities of Oregon or Utah. This report does not constitute a standard, specification, or regulation. 



\section{TABLE OF CONTENTS}

Executive Summary ............................................................................................................................ 1

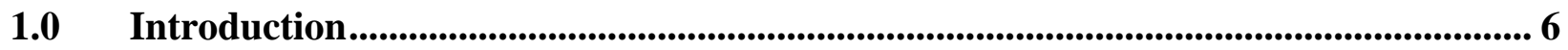

1.1 Study Goals ...................................................................................................................................

1.2 Report Overview.....................................................................................................................

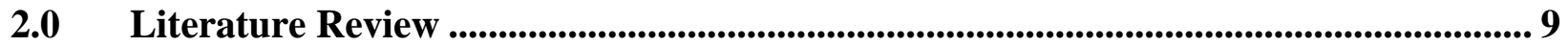

$2.1 \quad$ MPO Roles In Transportation-Land Use Integration.............................................................10

2.2 The Structure of MPOs..................................................................................................................... 12

2.3 Evaluating Metropolitan Collaboration .......................................................................................... 14

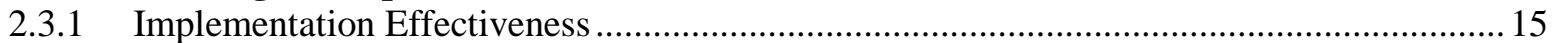

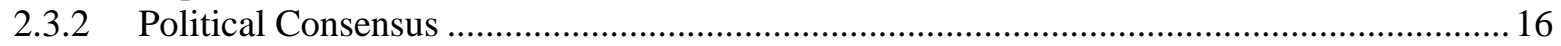

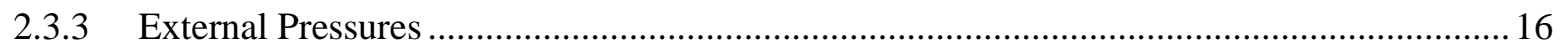

2.3.4 Implementation ...................................................................................................... 17

2.4 Metropolitan Centers And Transit-Oriented Development ................................................... 18

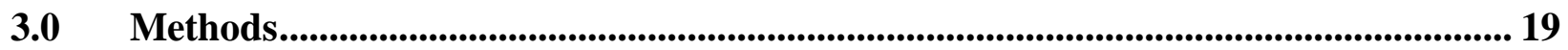

3.1 Metropolitan Cases.......................................................................................................................... 19

3.2 Case Study Analysis ............................................................................................................. 20

3.2.1 Plan Content Analysis .............................................................................................. 20

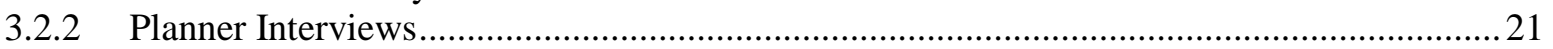

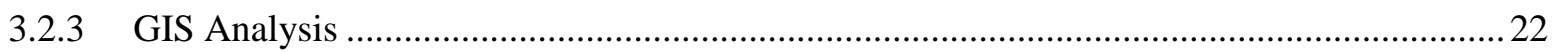

3.2.3.1 Center Selection ………………………………………………………………………22

3.2.3.2 Limitations of GIS Analysis...........................................................................................2

4.0 Denver Region ..................................................................................................................... 27

4.1 Denver Regional Council of Governments.............................................................................. 27

4.2 Metro Vision and Transportation Planning............................................................................. 27

4.2.1 Scenario Planning................................................................................................... 28

4.2.2 Current Centers Policies...................................................................................................... 31

4.3 Denver Area Case Study Cities .................................................................................................... 32

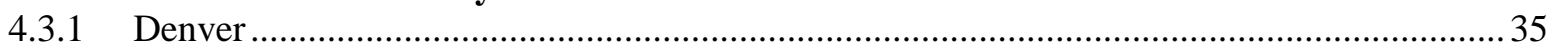

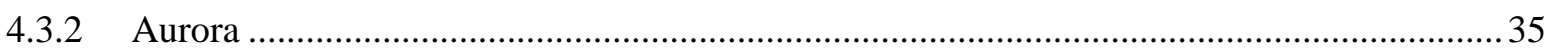

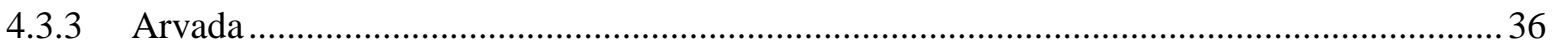

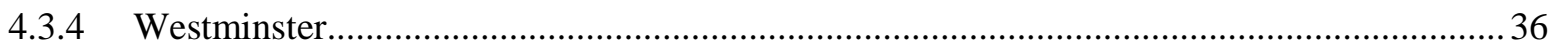

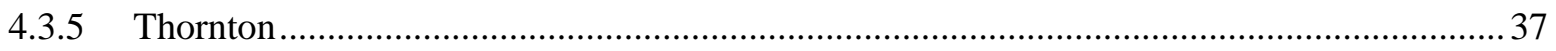

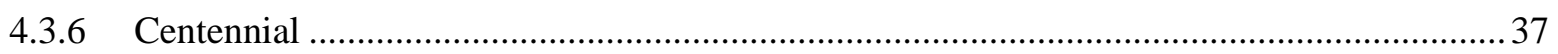

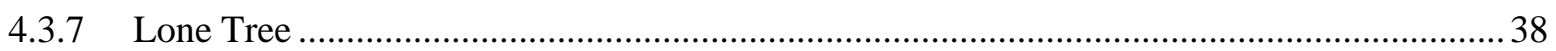

4.3.8 Greenwood Village ............................................................................................. 38

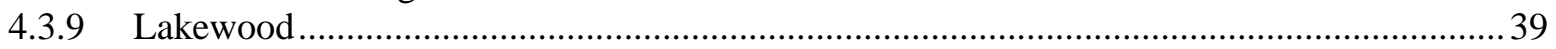

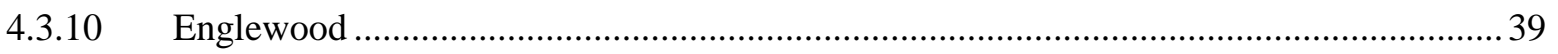

5.0 Salt Lake City Region.............................................................................................................. 40

$5.1 \quad$ Wasatch Front Regional Council ........................................................................................4

5.2 Envision Utah..................................................................................................................................... 41

5.3 Regional Planning In The Salt Lake Region ..............................................................................4 42

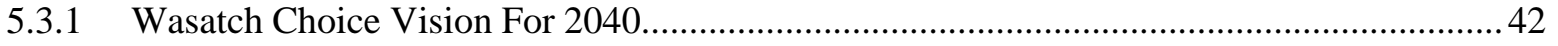

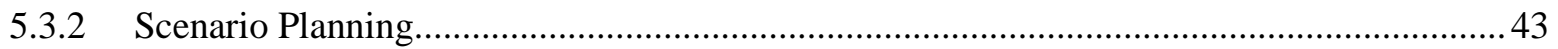

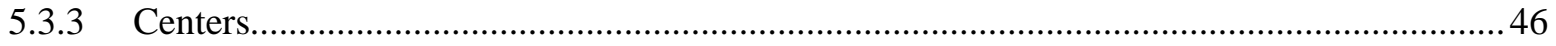

5.4 Case Study Cities ................................................................................................................................4 47 


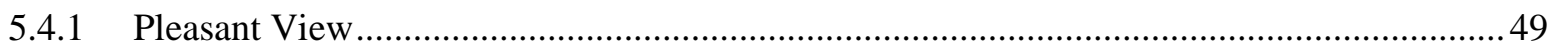

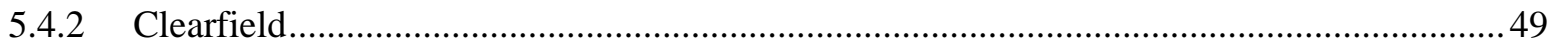

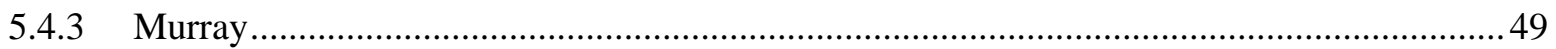

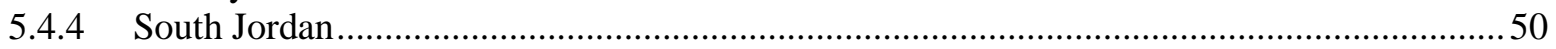

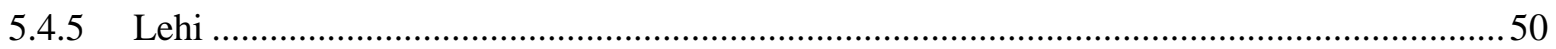

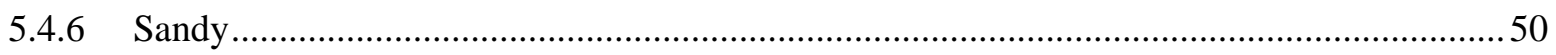

5.4.7 Salt Lake City ……………………………………………………………………. 51

6.0 Findings: CHanges in Planning ................................................................................... 53

6.1 Evolution of Regional Plans: Denver ...................................................................................... 53

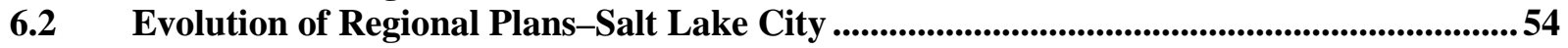

6.3 Local Plan Changes: Denver and Salt Lake City Regions.......................................................56

6.3.1 Regional Vision Adoption in Local Plans.........................................................................5 56

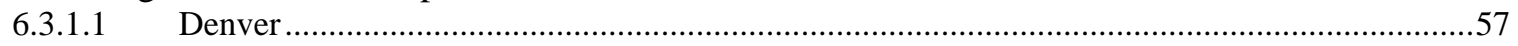

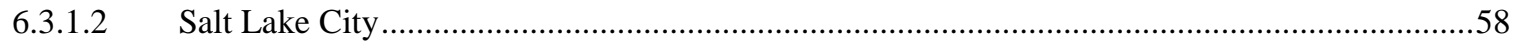

6.4 Goals and Indicators: Policy Crosswalk................................................................................... 58

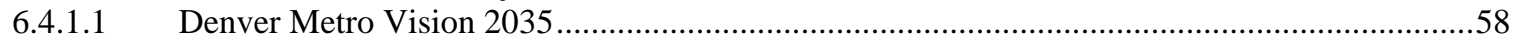

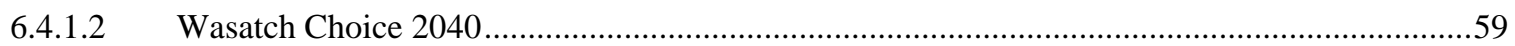

6.5 Metropolitan Centers ..........................................................................................................................60

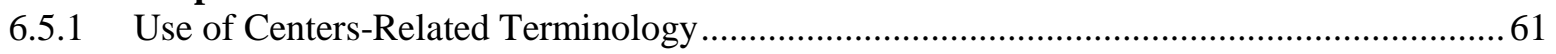

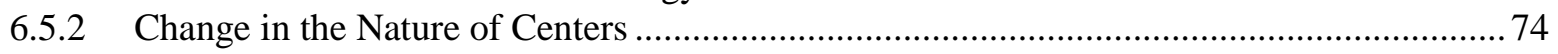

6.5.3 Transit-Oriented Development........................................................................................ 76

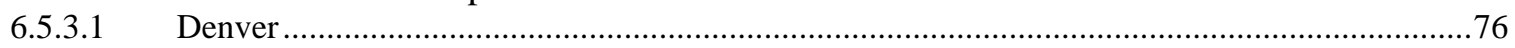

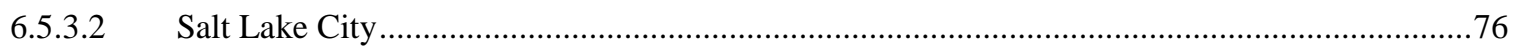

6.6 The Driving Forces Behind Centers............................................................................................. 76

6.6.1 Driving Force: Market Forces ........................................................................................ 78

6.6.2 Driving Force: Transit Investment and Types of Station Areas.............................................. 80

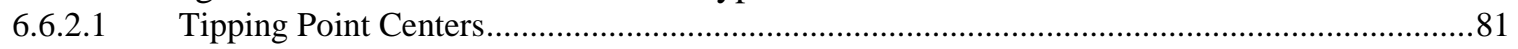

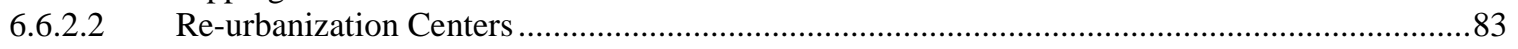

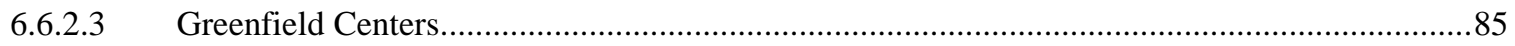

6.6.3 Driving Force: Planning and Local Investment ……………………………………......... 89

6.6.4 Driving Force: Sales Tax............................................................................................. 90

6.6.5 Driving Force: Grants and Funding Incentives ……………………………………............90

6.6.6 Driving Force: Regional Centers Concept and Policies....................................................... 93

6.7 Public and Political Response: Support and Opposition ........................................................94

7.0 Findings: Spatial Analysis....................................................................................................... 96

7.1 Denver Findings.........................................................................................................................97

7.1.1 Demographic: Population, Land Area and Density.................................................................. 97

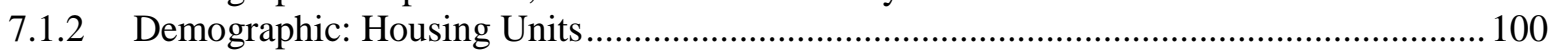

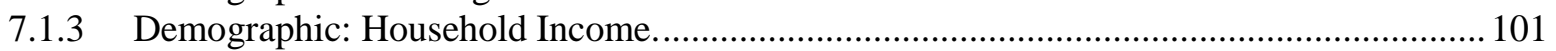

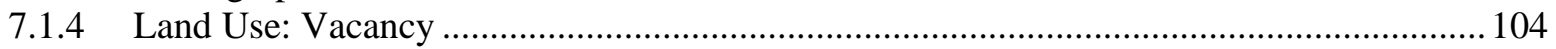

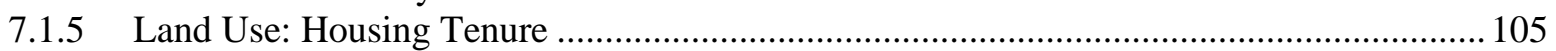

7.1.6 Transportation: Network ................................................................................................ 107

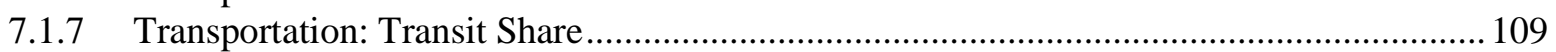

7.1.8 Transportation: Alternative Mode Share ..............................................................................111

7.1.9 Transportation: Car Ownership .................................................................................... 111

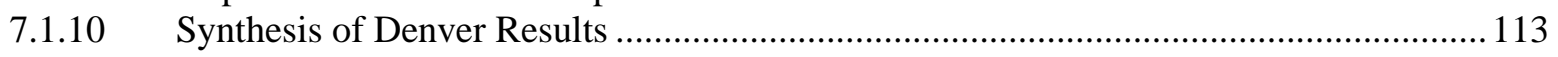

7.2 Salt Lake Findings ............................................................................................................................114

7.2.1 Demographic: Population, Density and Land Area.............................................................114

7.2.2 Demographic: Housing Units....................................................................................... 118

7.2.3 Demographic: Household Income....................................................................................120 


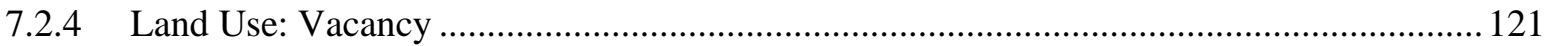

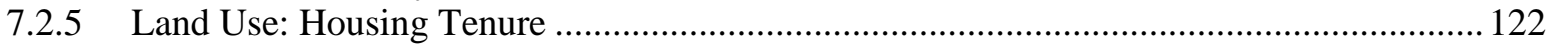

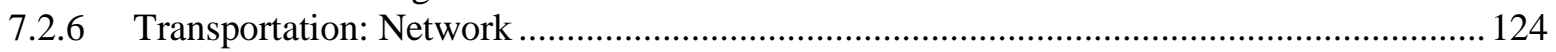

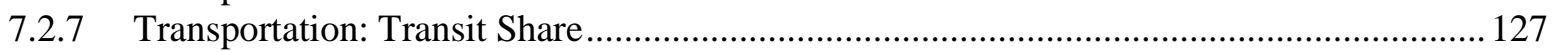

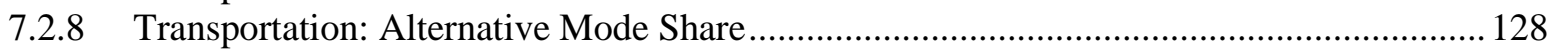

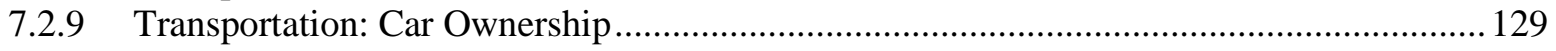

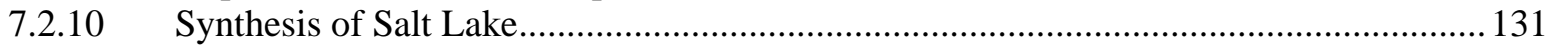

8.0 Implications ......................................................................................................................... 132

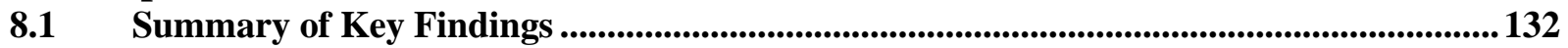

8.1.1 Adoption of the Centers Concept .............................................................................. 132

8.1.2 Center Concepts Have Suffered From Vague Concepts and Criteria ............................... 133

8.1.3 The Adoption of Transit-Oriented Development Concept .................................................. 133

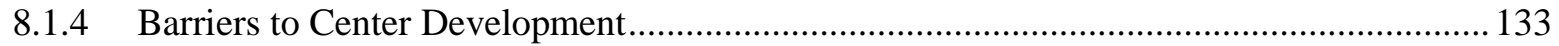

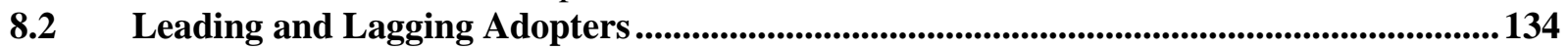

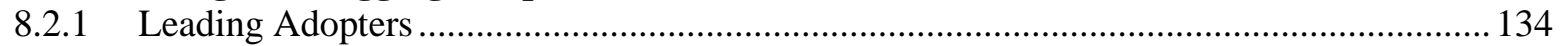

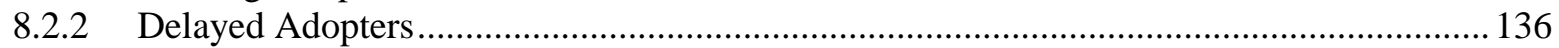

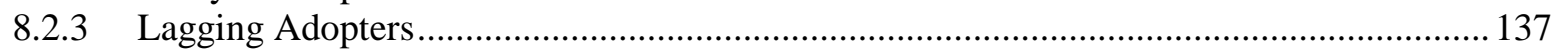

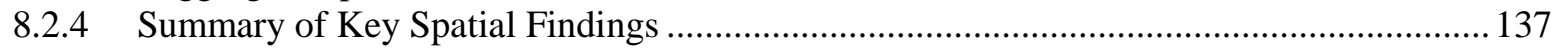

8.3 Recommendations and Transferable Lessons............................................................... 138

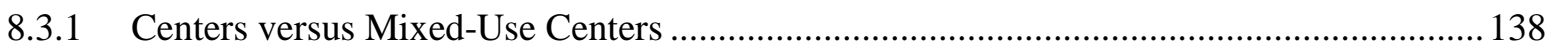

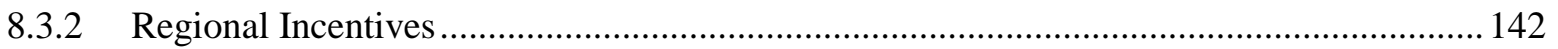

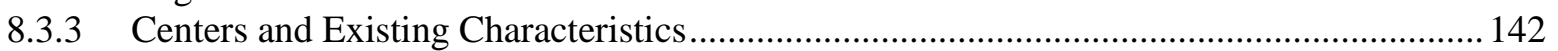

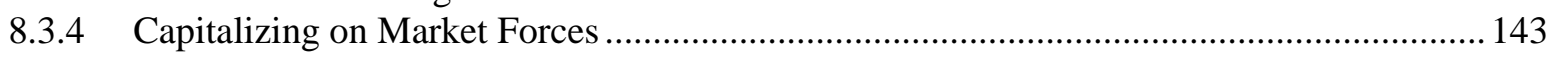

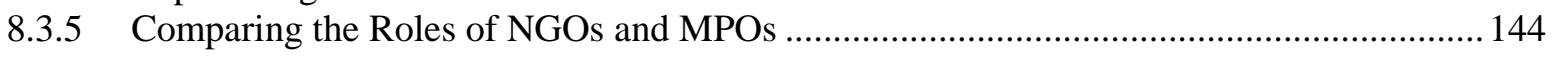

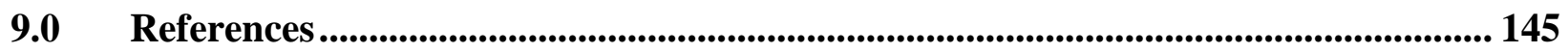

Appendix A: Plan Scoring Methods ............................................................................ 151

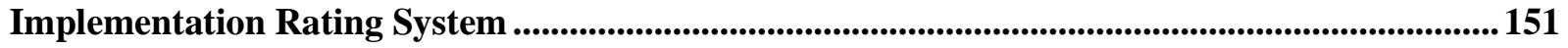

Appendix B: GIS METHODS................................................................................... 154

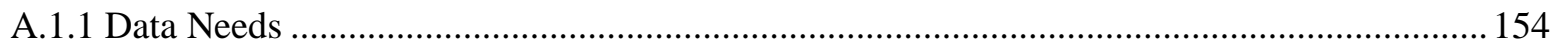

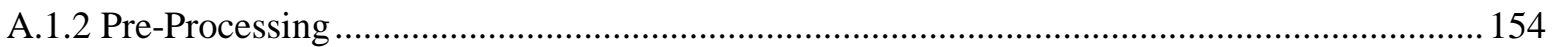

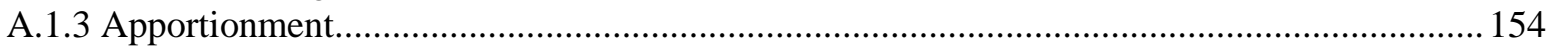

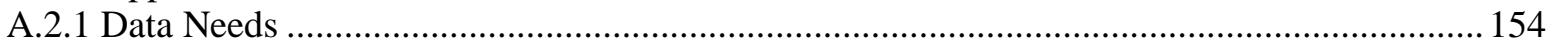

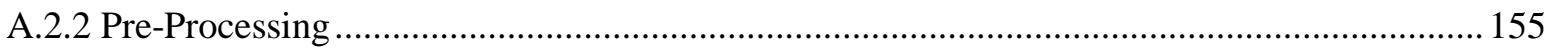

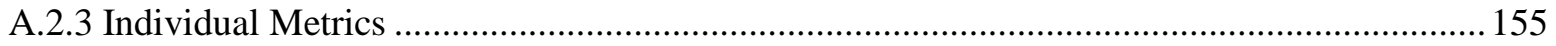

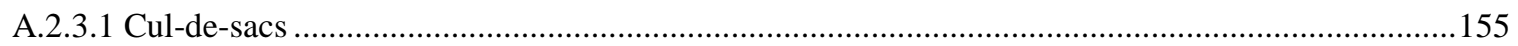

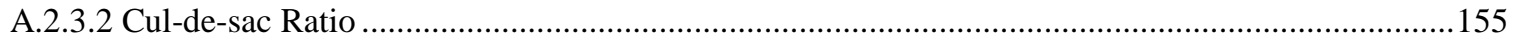

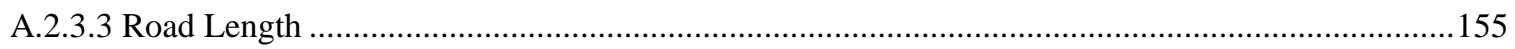

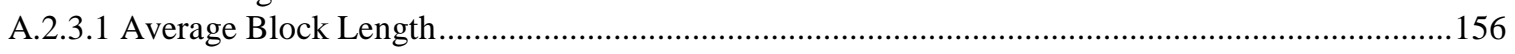




\section{LIST OF FIGURES}

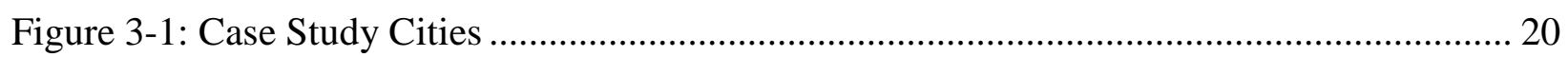

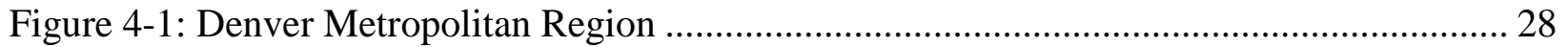

Figure 4-2: Demographic Summary (Denver Region) ......................................................... 33

Figure 4-3: Case Study Community Overview (Denver Region) ............................................ 34

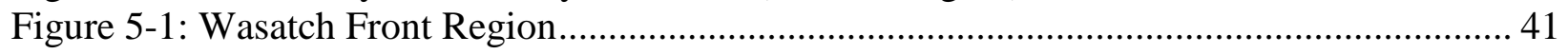

Figure 5-2: Demographic Summary (Salt Lake City Region) ............................................... 47

Figure 5-3: Case Study Community Profile (Salt Lake City Region) ..................................... 48

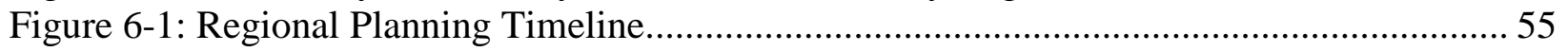

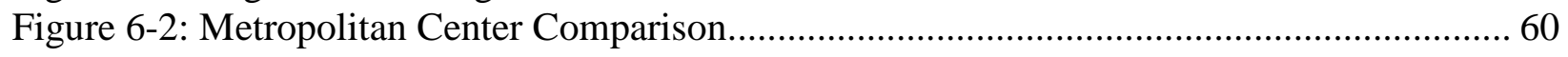

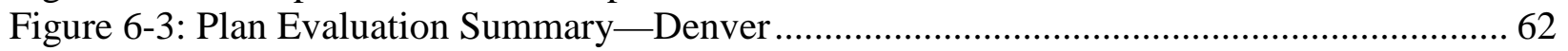

Figure 6-3: Plan Evaluation Summary-Denver (Continued)................................................ 63

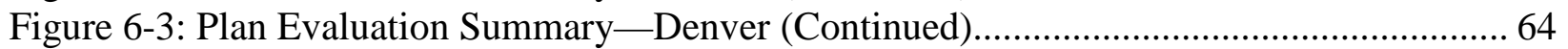

Figure 6-3: Plan Evaluation Summary-Denver (Continued)................................................ 65

Figure 6-3: Plan Evaluation Summary-Denver (Continued)................................................ 66

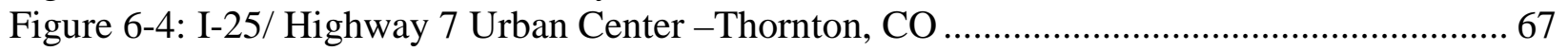

Figure 6-6: Plan Evaluation Summary-Salt Lake City.................................................... 70

Figure 6-6: Plan Evaluation Summary—Salt Lake City (Continued) ...................................... 71

Figure 6-6: Plan Evaluation Summary-Salt Lake City (Continued) ....................................... 72

Figure 6-6: Plan Evaluation Summary—Salt Lake City (Continued) ....................................... 73

Figure 6-7: Examples of Local Plan Evolution Center Concepts (Denver Region) .................... 75

Figure 6-8: Examples of Local Plan Evolution Center Concepts (Salt Lake City Region).......... 75

Figure 6-9: Factors Influencing Local Adoption of Centers (Planners’ Views).......................... 78

Figures 6-10: Housing and Neighborhood Preferences ...................................................... 79

Figure 6-11: Development in Arvada's Olde Town Neighborhood ......................................... 82

Figure 6-12: Development in the Salt Lake City Sugar House Neighborhood ........................... 83

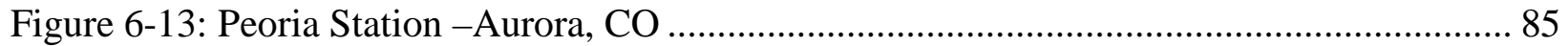

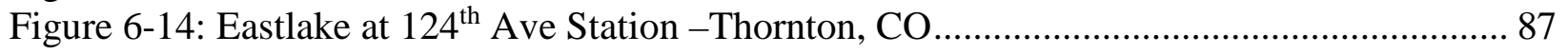

Figure 6-15: RidgeGate City Center -Lone Tree, CO ........................................................ 89

Table 6-16: Denver Area TIP Policy Criteria Related to Centers ........................................... 91

Table 6-17: Denver Area Allocation of Funding in Relation to Urban Center (UC) Criteria ...... 92

Table 6-18: Salt Lake City Area TIP Policy Criteria Related to Centers ................................... 93

Figure 7-1: Indicator Description.................................................................................. 96

Figure 7-2: Denver Land Area, Population and Density for Region, Cities and Select Centers,

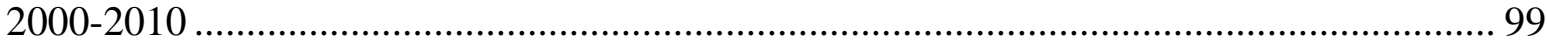

Figure 7-3: Denver Housing Units for Region, Cities and Select Centers, 2000-2010 ............. 101 Figure 7-4: Denver Household Income for Region, Cities and Select Centers, 2000-2008-2012

Figure 7-6: Denver Vacancy Rates for Region, Cities and Select Centers, 2000-2008-2012 .... 104

Figure 7-7: Denver Owner/Renter Share for Region, Cities and Select Centers, 2000-2008-2012

Figure 7-8: Denver Transportation Network Characteristics for Region, Cities and Select

Centers, 2000-2008-2012........................................................................................ 108

Figure 7-9: Denver Transit Share for Region, Cities and Select Centers, 2000-2008-2012 ...... 110 
Figure 7-10: Denver Alternative Mode Share for Region, Cities and Select Centers, 2000-20082012

Figure 7-11: Denver Car Ownership (Share with 0 or 1 Car) for Region, Cities and Select Centers, 2000-2008-2012

Figure 7-12: Salt Lake Population, Density and Land Area by Region, Cities and Select Centers, 2000-2008-2012 116

Figure 7-12: (continued) Salt Lake Population, Density and Land Area by Region, Cities and Select Centers, 2000-2008-2012.

Figure 7-13: Salt Lake Housing Units by Region, Cities and Select Centers, 2000-2008-2012 119 Figure 7-14: Salt Lake Household Income (in 2012\$) by Region, Cities and Select Centers, 2000-2008-2012

Figure 7-15: Salt Lake Vacancy Rate by Region, Cities and Select Centers, 2000-2008-2012. 122 Figure 7-15: Salt Lake Housing Tenure by Region, Cities and Select Centers, 2000-2008-2012

Figure 7-16: Salt Lake Transportation Network for Select Centers, 2014 ............................... 125

Figure 7-16: (continued) Salt Lake Transportation Network for Select Centers, 2014............. 126

Figure 7-17: Salt Lake Transit Share by Region, Cities and Select Centers, 2000-2008-2012.. 127

Figure 7-18: Salt Lake Alternative Mode Share by Region, Cities and Select Centers, 2000-20082012

Figure 7-19: Salt Lake Car Ownership (Share 0 or 1) by Region, Cities and Select Centers, 20002008-2012 130

Figure 8-1: Salt Lake City Transit Station Area District zoning ........................................ 136

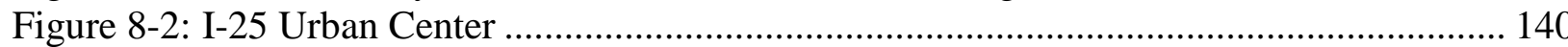

Figure 8-3: Colorado Station Center ............................................................................ 141 



\section{EXECUTIVE SUMMARY}

Across the United States, local governments and state agencies in metropolitan regions make a range of land use and transportation decisions that have cumulative impacts such as: increasing congestion, rising infrastructure costs, decreasing air quality, loss of open space, and increases in greenhouse gas emissions.

Metropolitan Planning Organizations (MPOs) are federally established organizations serving larger metropolitan regions that are required by law and regulation to carry out certain transportation planning and coordination responsibilities. In response to concerns about the lack of transportation and land use integration, many MPOs have developed voluntary regional visioning processes that examine scenarios and regional goals and objectives.

In some regions, MPOs have developed regional strategies for managing growth and focusing on development that promotes metropolitan centers (urban centers, transit-oriented development centers, etc). These centers are concentrations of housing, commercial development and employment. Many are served by transit or have the potential for being served by future transit. They can also reduce the number of vehicle trips by locating higher-density housing in proximity to local jobs and services. The Denver and Salt Lake City MPOs have identified centers as a key regional strategy and developed plans, policies and incentives to support their implementation.

Research question. In this study, a multidisciplinary team from the University of Oregon and the University of Utah examined regional metropolitan center programs and policies in the Salt Lake City and Denver regions. The goal of this study is to examine this topic on two levels. First, we are interested in how and why local governments have adopted the concepts of urban centers over time and the related supporting and constraining factors. Second, we are interested to understand how demographics, land use, and transportation choices have changed over time in the designated centers.

Case study regions. We examine these questions through an analysis of metropolitan and local planning in the Denver and Salt Lake City regions. Both regions have adopted voluntary regional policies for promoting smarter forms of regional growth, and they rely on regional consensus and collaboration rather than a state growth management framework. These regions offer an interesting context for this work, because they typify both some of the current challenges and the future potential opportunities facing metropolitan regions, including rapid growth, air quality concerns, low-density urban form, and a significant investment in mass transit.

Methods. The research team used a range of data sources to analyze this complex issue:

- Analysis of the regional plans and visions produced in both regions

- Analysis of comprehensive plans over time, including pre- and post-regional planning:

o Ten cities near metropolitan Denver

o Seven cities near metropolitan Salt Lake City

- Interviews with a range of individuals:

o Staff from regional agencies 
o Staff from transportation organizations

o Planners from each local jurisdiction

- Spatial analysis of demographics, land use and transportation characteristics in select metropolitan center locations within case study cities

\section{Results}

Our results examine the trends and themes from the plan analysis, planner interviews and spatial analysis. One of the biggest challenges in studying this question is the complexity of evaluating the impact of these policies over time. There are many factors at work in a metropolitan region that make it hard to dissect the relative importance of - for example-market forces, political views and policy impacts. Furthermore, there is a significant lag time between regional plans, local plans, and local development and redevelopment. This is particularly true during the time period of our study, because of the Great Recession and its impacts on employment and housing values. For example, some areas where we have strong evidence of redevelopment underway have not demonstrated changes in housing or property values in the data sets that we are using. Our results are divided into: (1) findings about the Denver and Salt Lake City regions, and (2) recommendations and transferable lessons from this research.

\section{Findings: Metropolitan Centers Concept}

- The concept of metropolitan centers (in its various forms) is appearing increasingly in local government plans, particularly in the Denver metropolitan region.

- The concept of metropolitan centers (in its various forms) has developed and matured over time, particularly in the Denver region. They have evolved from single-use areas (higher-density housing or retail) to more mixed-use areas.

- There is not clear evidence that regional plans and policies have had a significant influence on local adoption of the centers.

o In some jurisdictions, the transportation funding incentives have been cited as an influence on adopting centers.

o In many jurisdictions, market forces and transit investment appear to have far more significant influences on changing local plans and policies.

- The most significant changes in local plans have occurred in relation to transit, and the adoption of new transit-oriented development codes, transit station master plans, and special mixed use zoning districts applied to station areas.

\section{Findings: Policies Supporting Centers}

- The vague nature of centers has diluted some of the impacts of these policies. Both regions lack clarity and consistency about what constitutes a center and criteria for designating a center. As a result, there are large areas designated as centers that are unlikely to fulfill the goals of reducing vehicle miles traveled.

- There are vague criteria for evaluating the performance of centers over time and lack of regular assessment of demographic, land use, and transportation changes related to centers.

- Using transportation improvement program (TIP) incentive criteria has been a factor in some jurisdictions in supporting the centers concept. Yet given the low weighting attributed to these criteria, this has not been a significant influence for many jurisdictions. 
- Grant programs from the regional MPO and the transit agencies have been especially important for helping cities plan for redevelopment around transit stations, but the grants themselves have not been a factor motivating cities to adopt centers.

\section{Findings: Other Factors}

- Market forces have been one of the most significant new drivers of city efforts to create higher-density, mixed-use areas. These market forces are couched in terms of:

o Market and developer demand for multifamily housing

o The desire to develop amenity centers to attract Millennials and other residents more attracted to an urban living experience

o The desire to attract employers who are seeking out locations that are more urban to provide their employees with access to transit

- Transit investment has been a significant catalyst for new development within centers, but not all planners we spoke with were convinced that transit is a necessary condition for developing a mixed-use, higher-density, amenity center.

\section{Findings: Spatial Analysis}

Spatial analysis revealed interesting but inconclusive findings. The Great Recession coupled with rapid expansion of transit that did not match with Census data and muddied the analysis. Data were difficult to aggregate by center boundaries. As noted above, local information about specific centers often revealed a lag period with property development as it went through purchase, demolition and redevelopment phases. Despite limitations, analysis revealed interesting trends.

Key findings are as follows:

- Most centers saw increases in population and housing units. The centers that did not were in central cities near Denver and Salt Lake.

- In Salt Lake, most of the population growth went to suburbs. In Denver, a large share went to the city of Denver and first-ring suburbs.

- In Denver, median income uniformly declined. In Salt Lake, the trends were mixed. While cities saw declines in median income, centers in Lehi, Salt Lake, and South Jordan increased during the recession.

- The share of renters increased at the regional, city, and center level with few exceptions. This could be a result of the recession or a trend toward a mix of housing units.

- Some centers show trends toward gentrification with declining population coupled with increases in housing units, income and homeownership (relative to renters), likely due to condo development.

- Transit seems to guide trends in demographics, land use, and transportation in Denver, but the trends are less clear in Salt Lake.

- Transit lines that have been open longer generally show increases that are more substantial in population, housing units and transit ridership.

- While transit and alternative mode share changed little at the regional scale, several centers showed increases in transit ridership. This trend was more pronounced in Denver than Salt Lake. 
Additional indicators would improve understanding of the trends seen in data collected to date. Data representing 2015 would be more revealing than 2010 Census data or 2008-2012 ACS data.

\section{Implications}

- The concept of centers as implemented in the Denver and Salt Lake City regions is too vague to effectively induce cities to change their plans in response to regional policies and initiatives. The impact and implementation of centers would be more successful if:

o Centers were limited to smaller areas that are currently or could be transformed into areas with higher density that would be more likely to achieve regional housing and transportation goals.

o Narrower and more specific criteria for centers could increase the challenge of meeting the TIP transportation incentives, thus making them more influential.

o Narrower and more specific criteria could induce more change in local government plans and policies.

o Each region has over 100 centers. If fewer centers qualify for designation, grant funding for planning and development work could be increased to create bigger incentives for local government adoption and more rapid change in center redevelopment.

- The most substantial change in planning and land use is occurring in station areas. There is some question about whether transit stations are essential to catalyze this kind of development, but universal agreement that the planning and public investment that have gone into these station areas have resulted in significant transformations. These changes can be supported by:

o Grants and funding for planning and design related to station areas. Many jurisdictions indicated this was critical to accelerate the pace of change to develop these centers, because they did not have the resources to initiate this work.

o Technical assistance related to financing, urban design, parking, bike and pedestrian access, and other aspects of transforming station areas.

- In our analysis of plans and interviews with planners, we found that local governments have responded in varying ways to regional efforts to promote new development patterns. More research would be required to fully understand the range of community, political and other factors that may explain local responses to regional planning goals, but we grouped communities into several categories with common characteristics:

0 Leading adopters: generally the more urbanized cities that have little or no opportunities for urban expansion and which have opportunities for redevelopment or infill; many already had strategies in place to support the centers concepts

o Delayed adopters: generally more suburban communities that are now experiencing market demands, are seeking to create amenity centers to attract Millennials, or that have major redevelopment sites

o Lagging adopters: largely suburban communities with land use dominated by lowdensity residential development where there is little community support (and in some cases opposition) to higher-density development and multifamily residential development

\section{Implications and Transferable Lessons}


- Although centers have had a mixed response in both metropolitan regions, there is a significant increase in the development of mixed-use, amenity centers, most of which are focused around transit. These locations are likely to have the biggest regional benefits to housing, transportation and land use, and should be the highest priority for regional policies and incentives.

- Market forces are playing a significant role in driving new development in both metropolitan regions. The market demand includes desire for a more urban living experience; access to amenities and services; multifamily housing; and access to transit. MPOs may be able to capitalize on this trend by:

0 Providing analysis and evaluation of market demands

0 Working with developers and housing organizations to identify key factors necessary to support investment

o Sharing case studies from other regions that highlight trends and projects

o Offering grants to support planning in locations likely to attract this kind of development

o Providing technical assistance to local communities in relation to plan development, model codes, financing, urban design and active transportation strategies

- The urban form, location and accessibility of transit stations will have a significant effect on the ability of an area to evolve into a higher-density, mixed-use, amenity center. MPOs and transit agencies exploring fixed transit strategies (rail, light rail, and bus rapid transit) need to carefully consider the corridor and station locations in designing these systems. The different types of center areas will have significantly different needs and challenges, including:

0 Tipping point centers: Areas of existing density and amenities where the addition of transit access accelerates change and existing market forces. These are the areas likely to develop most quickly with the least amount of public-sector investment or changes in local plans and codes.

o Redevelopment centers: Areas with existing uses (industrial, commercial, office) that have the potential for future transformation will require a significant change in urban form and infrastructure. These areas will often require substantial public investment to transform the land use and improve bike, pedestrian and transit access. Many of these areas may evolve as either park and rides or development adjacent to transit without public investment.

o Greenfield centers: Areas with large areas of undeveloped land that offer a potential for the emergence of new mixed-use, transit-oriented development centers. These areas also require public investment in infrastructure, and its suburban location may require public investment in facilities such as structured parking to encourage higher-density development. Planning and zoning codes may play an important role in setting development standards, minimum densities and other policies to support these centers. 


\subsection{INTRODUCTION}

Across the United States, metropolitan regions encompass a large number of local jurisdictions making individual land use and infrastructure decisions. Issues of land use and transportation planning are closely interrelated, but as Cervero (2003) notes, the separation of land use and transportation decisions makes coordination difficult. Decisions about land use, transportation, and transit are spread across a range of entities, particularly due to the large number of municipal governments in these regions.

This cumulative set of decisions have contributed to low-density growth patterns that has, in turn, led to a range of increasingly challenging issues, including increasing congestion, rising infrastructure costs, decreasing air quality, loss of open space, and increases in greenhouse gas emissions (Kim, Cho, and Keane, 2015; Pendall, 1999).

Only a handful of states and metropolitan regions employ regulatory controls over regional land use planning. However, every large metropolitan region must undertake regional transportation planning to obtain federal transportation funding. This requires regions to model and predict future transportation needs, which is related to land use and growth patterns. For many regions, these models and scenarios demonstrate that transportation and other infrastructure and service funding cannot accommodate historic patterns of sprawling, low-density development.

In some urban areas, Metropolitan Planning Organizations (MPOs) are working to improve the integration of transportation and land use decision making through regional visioning processes (Bartholomew and Ewing, 2016, 2009). MPOs are federally established organizations serving metropolitan regions with a population in excess of 50,000. They were created to ensure that existing and future expenditures for transportation projects and programs are based on a continuing, cooperative, and comprehensive planning program. The MPOs are required by law and regulation to carry out certain transportation planning and coordination responsibilities. Part of this process is the programming of investments through a regional Transportation Improvement Program (TIP), which MPOs must update regularly.

One of the emerging strategies employed in some metropolitan regions is the promotion of development around higher-density, mixed-use centers (metropolitan centers). Considerable research has focused on the design and performance of centers, particularly those linked to fixed transit (transit-oriented development) (see e.g., Sung et al., 2014). These studies have focused on urban design (Alexander and Hamilton, 2015); the impacts of centers on behavior (Sciara and Handy, 2013); and the changes induced by fixed transit investment (Kay, Nolan and DePetrillo, 2014). However, there has been far less analysis of how regional policies have influenced local adoption of centers, especially "emerging" centers not served by fixed transit. Furthermore, there have been only a few studies at the metropolitan level to examine how regional policies have influenced local planning and development. The goal of this study is to help local governments and MPOs understand the factors supporting and constraining the adoption and performance of metropolitan centers to help improve future implementation. 
In the Denver and Salt Lake City metropolitan regions, MPOs have led collaborative, regional visioning processes to manage growth and transportation investment. A key component of these plans is promoting development around urban or metropolitan centers. These centers are concentrations of housing, commercial development and employment. Many are served by transit or have the potential for future transit. They can also reduce the number of vehicle trips by locating higher-density housing in proximity to local jobs and services. The Denver and Salt Lake City MPOs have identified centers as a regional strategy, and developed policies and incentives to support their implementation.

\subsection{Study Goals}

In this study, a multidisciplinary team from the University of Oregon and the University of Utah examined metropolitan center strategies in the Salt Lake City and Denver regions. The goal of this study is to examine this topic on two levels. First, we are interested in how and why local governments have adopted the concept of metropolitan centers over time and the factors supporting and constraining their implementation. Second, we are interested to understand how demographics, development and transportation decisions have changed over time in the designated centers.

We examine these questions through an analysis of metropolitan and local planning in the Denver and Salt Lake City regions. Both regions have adopted voluntary approaches to promoting smarter forms of regional growth, and they rely on regional consensus and collaboration rather than a state growth management framework. These regions offer an interesting context for this work, because they typify both some of the current challenges and the future potential opportunities facing metropolitan regions. The challenges include high growth rates, existing patterns of low-density development, rising infrastructure costs and complex voluntary regional planning. The potential opportunities include significant investment in transit, changing market conditions, and support for collaborative metropolitan planning.

\subsection{Report Overview}

This report summarizes the findings from the comparative work conducted by our research teams. The following sections describe the context, methods, findings and implications from this research:

- Chapter 2: Literature Related to Metropolitan Land Use and Transportation Planning

- Chapter 3: Research Methods

- Chapter 4: Denver Case Study

- Chapter 5: Sale Like City Case Study

- Chapter 6: Findings-Changes in Planning

- Chapter 7: Findings-Spatial Analysis

- Chapter 8: Implications 



\subsection{LITERATURE REVIEW}

The rise of a multi-nucleated centers approach to metropolitan land use-transportation planning has both precipitated and been facilitated by increased multiagency policy coordination, especially between metropolitan and local levels of government. Multiagency coordination is not, of course, unique to metropolitan transportation and land use. In areas such as natural resources management and social services, government and nongovernment organizations have confronted similar concerns. To address these issues, many organizations and agencies have developed coordinated or collaborative governance approaches. These approaches assume that existing formal governance systems will continue to function, but develop other governance strategies and mechanisms to aligning activities (see e.g., Agranoff and McGuire, 2003; Ansell and Gash, 2008; Margerum, 2002).

Coordinated and collaborative governance also assumes that it is difficult to create new organizations or state frameworks with the authority to encompass these problems. In some states, metropolitan land use is coordinated through state-level programs. A limited number of states (Oregon, Hawaii, Washington, Vermont) have state-level growth management that mandates local plans be consistent with state goals or criteria. In New Jersey, this system is delivered through a state-local negotiation process. Other states rely on incentive-based "smart growth” programs (Maryland, Wisconsin, North Carolina, Pennsylvania) (Gale, 1992; DeGrove, 1984; Bollens, 1992). Many of these state-level programs have experienced ongoing political challenges from a range of interest groups (Lewis and Baldasarre, 2010; Chapin and Connerly, 2004). In Florida, this resulted in the dismantling of its 40 -year-old state growth management program.

As a result, most metropolitan regions addressing land use planning at the regional level rely on what Gale (1992) calls a regional-local cooperative approach. These efforts are led by MPOs that have often "backed into" land use planning via their regional transportation planning role. The constraints of transportation funding and air quality conditions require these regions have to look critically at land use patterns. Furthermore, increasing demands for multifamily housing and growing local government concerns about the infrastructure and service costs of low-density land use patterns have all generated increasing interest in collaborative regional planning efforts. Several studies have identified strategies for coordinating transportation and land use, including North Carolina (Rodriguez and Godschalk, 2003); Virginia (Miller et al., 2004); and Florida (Hendricks and Seggerman, 2005). However, this research focused primarily on topics such as travel demand tools, forecasting, and legislative options. As the North Carolina researchers highlighted, there is a need to identify institutional mechanisms that allow state and regional transportation planners "to reach out to local land use planners to increase collaboration among parties and improve planning outcomes” (Rodriguez and Godschalk, 2003, 40).

In the following section, we review the historical role of metropolitan transportation and land use planning, including the role of MPOs. We also summarize the research related to MPO governance and structures, the role of metropolitan centers, the findings from analysis of growth management efforts, and the research on collaborative metropolitan governance. 


\subsection{MPO Roles In Transportation-Land Use Integration}

Metropolitan-scale, transportation-land use policy integration is a relatively recent phenomenon, arising from the mid-century practice of transportation systems planning. Although project-level transportation planning arguably had been occurring in the United States for decades-the early turnpikes in Virginia and Pennsylvania and the Transcontinental Railroad come to mind-the first significant systematic planning effort was conducted in response to the Federal-Aid Highway Act of 1934 as a series joint highway planning surveys done by the U.S. Bureau of Public Roads and individual state highway departments (Weiner, 1999). These rudimentary initiatives were soon dwarfed by the planning undertaken to construct the Interstate Highway System, first authorized in 1944 and then significantly funded in 1956.

While these efforts were distinct from their project-oriented predecessors in that they focused on entire systems, they completely ignored non-highway transportation systems and gave little attention to transportation-land use influences. The real shift came with the Federal-Aid Highway Act of 1962. Under this act, "urban areas" were required, as a condition for receiving federal funding, to adopt long-range transportation plans for entire metropolitan areas and for multiple modes of transportation through a process that was to be "continuing, comprehensive, and cooperative" (the " $3 \mathrm{Cs")} \mathrm{and} \mathrm{that} \mathrm{incorporated} \mathrm{the} \mathrm{effects} \mathrm{that} \mathrm{land} \mathrm{use} \mathrm{patterns} \mathrm{have} \mathrm{on}$ travel demand. Though unique as a statement of federal law, Weiner $(1999,33)$ notes that the mandate "was not a new congressionally conceived requirement, but rather an endorsement of a process already being proved effective in many areas"-during the 1950s several transportation studies had pioneered "hyphenated" land use-transportation analyses-the 1962 act and subsequent implementing memoranda from the Bureau of Public Roads (1963) mainstreamed the practice. The reverse interaction - that of transportation on land use and development-was largely disregarded by the new planning regime, despite growing concern about the social and environmental impacts that highway construction was having on communities (AASHTO, 1962). The primary purpose of transportation planning remained focused on mobility and on ways to accommodate growing travel, primarily by automobile (Solof, 1997).

Transportation systems planning practice came of age in the decades following passage of the 1962 act, facilitated and quantified by increasingly robust computer models and executed by a new governmental entity: the MPO. The creation of MPOs in the early 1970s was in response to increased environmental awareness, mounting resistance to urban highway construction, and heightened concern over the financial health of transit agencies recently acquired by a variety of governmental entities. Prior to 1973, the regional intergovernmental bodies that facilitated the 3C process were playing, at most, technical and advisory roles, leaving most of the authority with state highway officials.

As part of the Federal-Aid Highway Act of 1973, MPOs were formally recognized, universalized to all metropolitan areas, and empowered to have decision-making authority. Once recognized, a number of federal programs requiring regional planning came within their purview, in addition to transportation (Lewis and Sprague, 1997). This golden era of MPOs, however, was short-lived and with the Reagan administration's concept of "new federalism," the number of planning programs controlled or implemented by MPOs went from 39 to one and that sole remaining subject - transportation — was constrained by new regulations giving states substantial authority 
in determining MPO functions (Lim, 1983; McDowell, 1984). In the eyes of many, this relegated MPOs to the role of merely rubber-stamping decisions already made by state highway departments (Solof, 1997; Wolf and Farquhar, 2005).

After the procedural/structural changes associated with the rise and fall of MPOs, the next major policy innovation signaling a move toward transportation-land use integration came as part of the Clean Air Act Amendments of 1990 (CAAA). The continued failure of many metro areas to meet national ambient air quality standards (NAAQS) for ozone and carbon monoxide- two pollutants significantly tied to mobile sources - the CAAA strengthened the requirements for metro areas classified as "severe" or "extreme" for ozone, or "serious" for carbon monoxide to adopt transportation control measures (TCMs) to offset projected growth in vehicle travel over the course of the planning horizon. Metropolitan areas could select from a long list of TCMs enumerated in the CAAA, including programs to improve public transit and other alternative transportation modes, restrict automobile use in downtown areas, and "generally reduce the need for single-occupant vehicle travel, as part of transportation planning and development efforts of a locality, including programs and ordinances applicable to new shopping centers, special events, and other centers of vehicle activity" (42 U.S.C. §7408(f)(1)(A)). Although this latter option speaks to transportation-land use integration, the literature suggests that few regions opted to employ that choice initially (Knapp et al., 1994). Over time, it has been the metro areas with the most serious air quality violations that have evidenced a greater willingness to engage land useoriented transportation strategies, presumably because other strategies have not been completely successful (U.S. GAO, 2002: Wolf and Farquhar, 2005).

A second and further-reaching change imposed by the CAAA on transportation planning came from alterations in the provisions on "transportation-air quality conformity," requiring that transportation plans conform to "a [state implementation plan's] purpose of eliminating and reducing the severity and number of violations of the NAAQS and achieving expeditious attainment of the standards" (Weiner, 1999, 170). Though not specifically requiring increased coordination of transportation and land use policies, the new conformity provisions at least gave impetus for engaging the issues together.

That engagement was further advanced just one year after the passage of the CAAA with the adoption of the Intermodal Surface Transportation Efficiency Act of 1991 (ISTEA), which revolutionized the rules for transportation systems planning, at least on the surface. In addition to adding significant cross-modal funding flexibility, ISTEA provided MPOs with a significant expansion of factors that had to be considered in long-range transportation planning processes, including " $[\mathrm{t}]$ he likely effect of transportation policy decisions on land use and development and the consistency of transportation plans and programs with the provisions of all applicable shortand long-term land use and development plans” (ISTEA §1024(a), 105 Stat. at 1957-58). According to the Senate Committee on Environment and Public Works, which developed this language, the intent was for MPOs to demonstrate that capacity expansion will not be accompanied by increased development in a manner that will frustrate the goals of expansion. MPO plans should also specify how land use plans may encourage any necessary travel demand reduction or encourage the use and financial viability of mass transportation and non-motorized travel (S. Rep. No. 102-71, at 29 1991). 
As illuminated by the committee's explanation, this requirement went much further than merely requiring recognition that land use patterns influence travel behaviors, as the prior $3 \mathrm{C}$ planning guidelines did. It, in fact, called on MPOs to guard against planning and building facilities that might induce land development that could create excessive travel on the proposed facility. It also sought to have MPOs investigate future land use patterns that might reduce the need to travel.

Transportation bills following ISTEA streamlined the planning factors MPOs were to use in the creation of long-term system plans and, in that, paring down the focus on land use integration was lost. Still, the impetus to move toward greater integration and coordination on transportation and land use policies has been reflected in metropolitan planning practice in the decades since ISTEA, particularly in the rise of land use-transportation scenario analysis. Research by Bartholomew (2007) and Bartholomew and Ewing (2009, 2010, 2016) identified more than 100 examples of regional-scale scenario analyses utilizing some measure of land use-transportation policy integration and coordination. The seeming ubiquity of the approach led Ewing to opine in 2007 that the approach had, in the space of a decade and a half, gone from the fringes of planning practice to being a staple (Ewing, 2007). This conclusion was further cemented by Congress' action in 2012 to include scenario planning as an optional technique for the creation of federally required long-transportation plans (23 U.S.C. sec. 134(i)(4)), thereby ratifying the techniques already being used by dozens of MPOs.

Although the technique has many variations, the modal MPO-led scenario planning project begins with the assessment of a trend scenario where urban devel opment and transportation investment patterns of the recent past are assumed to continue to the planning horizon (typically 20 to 50 years in the future). Analysis of this scenario's impacts on land consumption, air quality, and transportation systems almost al ways indicates results that are dismal, often shocking. The trend scenario, thus, not only creates a baseline for comparing with other, alternative scenarios, but frequently al so provides political motivation for crafting al ternative scenarios. The al ternative scenarios are then assessed for their impacts on the same measures, and the results are compared to help inform the development of new policies on transportation, land use, and related topics. Examples from the Denver and Salt Lake Regions are summarized in the sections discussing regional planning in each region.

\subsection{The Structure of MPOs}

The structure of MPOs post-Reagan has been the subject of significant academic interest. Sanchez $(2006,2)$ notes "MPO boards wield powers to adopt and endorse regional transportation plans, approve budgets, approve agreements, adopt rules, and oversee operating procedures. The plans, budgets, contracts, and agreements approved by MPOs all directly affect the location and extent of transportation investment.” Because of the degree of impact these investments can have on communities, the type of decision-making structure employed by MPOs can have real and substantial impacts on communities. Despite some variation from MPO to MPO, Hamroun (2006) notes in her review of 65 MPOs that virtually all contain the following elements in common: a policy board, an executive committee, a technical advisory committee, a citizen advisory committee, and technical staff. Many MPOs, however, include additional committees for specialized purposes (e.g., ADA, air quality). 
The decision-making chain in most MPOs starts with the technical advisory committee (TAC), which is comprised of technical staff of the MPO's constituent members. Given the level of technical expertise of most TAC members and the regularity with which they typically interact with each other in professional settings, TACs tend to have a dominant influence on final decisions, over and above the other players in the process (Hamroun, 2006; Deyle and Wiedenman, 2014). Policy boards, which have the final say in the decision process, come in a variety of sizes. In Hamroun's (2006) study, the range ran from three (Capitol Region MPO, Connecticut) to 70 (Sacramento Council of Governments), with a plurality between 10 and 19.

Most commentators observe four basic MPO structure-types: a council of governments (COG) in which members represent constituent local governments in the region on a one-government/onevote basis; an appointed body to which members are designated by a variety of state and local government interests; a unitary county government in which the county and the MPO are coterminous; and an entity that is effectively a field office of the state department of transportation. The most common of these types, by significant degree, is the COG version (Lewis, 1998; Lewis and Sprague, 1997; Wolf and Farquhar, 2005; Lovelady, 2009).

Although MPOs are conceptualized as instruments of regional governance, the local interest orientation of the body's members frequently results in decision making that is characterized by a battle of competing local interests, rather than one based on a more regional conceptualization (FHWA, 2002; Hamroun, 2006). In other words, members have difficulty seeing beyond their local interests to a more regional frame. Other commentators see MPOs as continuing to labor under the control of state DOTs, despite policy innovations over recent decades (e.g., through ISTEA and its progeny) intended to give MPOs greater autonomy (Olson, 2000; Edner and McDowell, 2002; Vogel and Nezelkewicz, 2002).

Of course, there are exceptions to these generalizations. Goetz, Dempsey and Larson (2002) report high levels of both regional perspective and positive collaboration with the state DOT in Dallas/Ft. Worth (compared to Phoenix, Denver, and Seattle). Some commentators see in these and similar data the emergence of a broader trend in which the MPO serves as facilitator for metropolitan collaboration (ACIR, 1997; Goldman and Deakin, 2000; Norris, 2001). A consistent element across these observations is the enhanced legitimacy associated with MPOs' increased technical and professional expertise (Wolf and Farquhar, 2005; Wolf and Fenwick, 2003; Goetz, Dempsey and Larson, 2002).

In their analysis of TACs from 88 MPOs, Deyle and Wiedenman (2014) found statistical confirmation of a series of hypotheses founded on collaborative process theory. Basing their work on Ansell and Gash (2008), Innes and Gruber (2005), and Margerum et al. (2011), Deyle and Wiedenman surveyed TAC members on the degree to which the attainment of positive "collaboration space" attributes correlated with process outcomes. The authors grouped the collaboration space variables according to Habermas's DIAD structure in which (1) participants represent the "'full diversity of interests' affected by their actions"; (2) participants are interdependent, in that they are "dependent upon each other for attaining their goals"; and (3) the collaborative process amounts to "'authentic dialogue”" (p. 258). Many of these, plus several "starting condition" variables were significantly associated with "second-order" variables of capacity building and enhanced relationships and the "first-order" variables geared toward 
measuring plan quality_ - "achieving efficient mobility (movement of people and goods) and safe mobility, meeting the real transportation needs of the region, and allocating funds equitably" (p. 267)—although decision making by consensus was not significantly correlated.

Many commentators note that despite some variation in MPO structure and operations, most fall prey to some sort of bias, the most common type relating to the nature of representation on MPO policy boards (Benjamin, Kincaid and McDowell, 1994: Lewis, 1998; Sanchez, 2006; Luna, 2015). Given the predominance of COG-type structures, many MPO boards operate under the rule of one-jurisdiction/one-vote. Because of the large variation in population sizes jurisdiction to jurisdiction, this fact alone can lead to representational imbalances, with small-population jurisdictions getting more proportional influence than large-population jurisdictions. In his analysis of 50 large MPOs, Sanchez (2006) found that only 29\% of MPO policy board members were from urban jurisdictions, even though these jurisdictions collectively contained nearly double that percentage in regional population (p.8). Significantly for this study, Sanchez found the Wasatch Front Regional Council to be one of the most unbalanced on this metric. Compounding these imbalances is the fact that the typically more numerous outer suburban jurisdictions are often observed as having more in common with each other than with central cities or inner-ring suburbs and tend to vote together, thereby increasing their clout (Orfield, 2002).

Because the central jurisdictions tend to have higher concentrations of traditionally disenfranchised populations - racial minorities and low-income households - the proportional imbalances also imply the presence of racial and income biases (Sanchez, 2006). In his analysis of the Boston-area MPO, Luna (2015, p. 291) concluded: "the representation structure of one government, one vote creates a strong and consistent relationship between relative representation and race and ethnicity, such that communities and subregions with higher proportions of nonHispanic white residents are consistently overrepresented and, conversely, communities and subregions with higher proportions of non-whites are underrepresented.” These inequities have led to frequent charges that COG-type MPOs violate the guarantee of one-person/one-vote protected by the Equal Protection Clause of the $14^{\text {th }}$ Amendment (e.g., Lewis, 1998). When faced with such challenges, however, the federal courts have consistently found that MPOs serve administrative, not legislative, functions and as "special purpose", governments are not subject to one-person/one-vote requirements (Yan, 2013). Nevertheless, to help counteract some of these inequities, some MPOs employ population-weighted appointment or voting schemes (Lewis, 1998; Lovelady, 2009).

\subsection{Evaluating Metropolitan Collaboration}

In many metropolitan regions, MPO responsibilities for transportation planning has led to regional visioning processes. These processes are generally voluntary and collaborative processes aimed at aligning long-term, land use decision making with long-term transportation planning. While the MPOs generally have no authority over land use decision-making, their role in transportation planning and allocating transportation funding has served as an indirect policy lever to promote metropolitan collaboration. 
There is considerable research on the principles and best practices related to collaborative governance (Ansell and Gash, 2007; Emerson, Nabatchi and Balogh, 2012; Huxham, Vangen, Huxham and Eden, 2000; McGuir, 2006). This literature identifies a number of key system factors and key drivers such as leadership, incentives and interdependence (Emerson et al., 2012). The literature also highlights key aspects of the collaborative governance approach, such as trust, mutual understanding, principled engagement, and institutional arrangements or networks to support the ongoing governance activities (Emerson et al, 2012; Huxham et al, 2000; Margerum, 2011).

There has been less clarity about linking governance approaches to outcomes, often because of the time frame, complexity and effort required to demonstrate trends in these outcomes. As a result, researchers assert that is important to consider process outcomes (e.g., shared data, increased understanding, shared perspectives), outputs (e.g., plans policies and agreements from collaboration), interim outcomes or performance measures (e.g., development permits located near transit stations, housing density), and outcomes that measure impact (e.g., air quality, congestion, urban density) (J. E. Innes, 1999; Margerum, 2011; Thomas and Koontz, 2011).

Fewer studies have examined collaborative governance in the context of metropolitan regions, but as these efforts become more widespread there is increasing attention being paid to these efforts. Studies have revealed consistent findings with regard to context, drivers and governance structures. The question of implementation results in collaborative metropolitan governance has been more varied, in part due to the more contentious politics, the greater complexity of governance settings and fewer external pressures to enforce compliance. Several studies of collaborative metropolitan governance have evaluated outputs and outcomes in regions such as Denver, Sacramento, and Atlanta (Barbour and Teitz, 2006 2009; Chakraborty, 2010; Goetz, 2013; Helling, 1998; J. Innes and Booher, 1999; Jonas, Goetz and Bhattacharjee, 2014a). These studies reveal several key themes and debates related to implementation.

\subsubsection{Implementation Effectiveness}

One of the ongoing questions in many regions is whether collaborative metropolitan governance is having an effect on growth and development patterns. In Helling's (1998) study of Atlanta's regional efforts, she concluded that the voluntary process did not produce implementable plans and had little impact on development outcomes. Barbour and Teitz (2006) concluded that collaborative planning efforts in California ("Blueprint Planning") have had mixed implementation success, and they tend to reflect a collection of parochial interests. Margerum (2005) found that first-generation regional planning efforts in the Denver region were having mixed success in terms of local government responses. The plans helped establish new regional goals for growth management and focusing development in centers, but many local governments were leery of the regional power. A more recent study by Goetz (2013) concluded that local jurisdictions in the Denver metropolitan region have complied with a regional vision when they saw financial benefits.

Most regions have relied on grants and transportation funding criteria to encourage local governments to support regional objectives. Regions such as Denver, San Diego, and Atlanta have created funding programs that incentivize local governments to focus more development in 
centers (Margerum, Brody, Parker and McEwen, 2011). However, the regional goals for higherdensity, mixed-use development focused in centers has also faced political and public opposition in some areas. In particular, residents in low-density, suburban communities have voiced opposition to higher density (Chakraborty, 2010). Other MPOs have gone further by requiring extension of transit stops in their region to be contingent on adopting supportive land use policies. However, the lack of integration with county transportation agencies and their significant resources has limited the ability to integrate land use and transportation planning (Barbour and Teitz, 2006).

Several studies have found that collaborative metropolitan planning has influenced local jurisdictions in more ways that are indirect. Goetz (2013) argues that while regional efforts in Denver have been "less than a bold new horizon" it has been more effective because of a broader coalition of interests that includes all levels of government, the development community and the public at large. Similarly Innes, et al (1994) argue that regional consensus building has led to long-term secondary changes in greater awareness of regional issues, stronger consensus on goals, and changes in the perceptions of regional planning and growth management. Margerum (2005) found varied responses to Denver's regional planning efforts, but the collective set of implementation tools and awareness of regional issues was increasing elected officials' understanding of the relation between local decisions and plans with regional issues.

\subsubsection{Political Consensus}

A consistent theme in many of these studies is the importance of political consensus in developing a collaborative governance approach and the difficulty of maintaining it over time. Jonas et al's (2014) review of Denver's collaborative efforts cites the importance of regional political consensus driven by the Metro Mayor's caucus. The caucus is a voluntary, consensusbased organization of 40 mayors designed to provide a non-partisan cooperation on issues affecting the metropolitan region (Jonas et al., 2014a; Metro Mayors Caucas, n.d.). Jonas, et al. (2014a) note that the caucus has worked closely with the Denver Regional Council of Governments (DRCOG) to support Metro Vision and the efforts to expand the region's light rail system. Similarly, collaborative efforts in the Sacramento region have induced both a stronger shared vision for the region, but researchers also suggest policies that present more political liability in local jurisdictions are less likely to sustain support (Allred and Chakraborty, 2015).

\subsubsection{External Pressures}

Also important to consider in the context of each region is the external forces that pressure collaborative efforts to achieve implementation results. As noted above, amendments to the federal Clean Air Act have required greater integration of land use and transportation planning. In Atlanta, regional transportation planning has been challenged in court by environmental groups due to the region's deteriorating air quality (Bullard, Johnson and Torres, 2000).

Several studies of metropolitan Denver cite public concerns about growth impacts and support for regional light rail as important motivators for elected officials to support implementation efforts (Jonas, Goetz and Bhattacharjee, 2014b; Margerum, 2005). The FasTracks sales-tax vote funded a significant expansion of the region's light rail system, providing a key component to 
implementing its regional centers strategy. Denver's mayor asserted that suburban mayors were crucial in the success of this initiative. Surveys and interviews with elected officials in Denver also revealed that they felt public pressure to manage growth due to concerns about air quality, infrastructure costs and loss of open space. Even among elected officials that opposed regional planning efforts, they were willing to "give a little" as a way to "pacify anti-growth constituencies” (Margerum, 2005, 383). Several authors also note growing public concern in many regions about the impacts of sprawl, which has created a general sense of the need to respond (Goetz, 2013; Margerum, 2005). Jonas (2014a) asserts that direct democracy has also played an important role in Denver, with voters approving a regional sales tax to support FasTracks, the largest urban rail transit construction program in the U.S.

\subsubsection{Implementation}

Much of the literature on collaborative regional planning is skeptical of its ability to induce change in local planning systems or development patterns. Helling (1998) concluded that voluntary processes in metropolitan Atlanta did not produce implementable plans and they would have little impact on development outcomes. Barbour and Teitz (2009) suggested that California's regional blueprint planning process was generating plans that merely reflected a collection of parochial interests (Barbour and Teitz, 2006). Margerum's (2005) survey of elected officials revealed mixed support among the region's elected officials. Some described Metro Vision as a "valiant effort" that was better than no regional plan at all; others felt it was a "sham" to cover up business as usual; and others viewed it as small limits to "pacify anti-growth constituencies” but retain flexibility. Goetz’ (2013) study of the Denver region's efforts concluded that local jurisdictions have complied with the regional vision when they saw financial benefits.

The primary implementation results cited in various studies have been the new vision and awareness of regional issues and concerns. Innes et al (1994) suggested that evaluations of implementation success should also consider long-term secondary change induced by consensusbased efforts. Innes and DiVittorio (2010) suggested that the value of collaborative processes be in social learning and building the capacity of regional stakeholders over time, including building ongoing forums for debate and discussion. Margerum (2005) also cited the increased regional understanding as a significant factor, but noted that maintaining this regional view is challenging among numerous elected officials who are constantly changing and vary in their communication effectiveness with their elected colleagues. Finally, Goetz (2013) contends that regional planning efforts like that occurring in metropolitan Denver are building a stronger regional identity, less jurisdictional infighting, and greater consensus on the issues of regional importance.

It is also important to note that functional challenges of plan implementation are not unique to regional planning. The issue of plan implementation is nearly as old as planning itself and has as its frame the question of how well implementation actions align with the aspirations contained in relevant plans. Ultimately, the question has to do with vertical consistency. While the issue here is the degree to which local plans match with the contents of regional plans, the question of whether actual development on the ground follows any plan, local or regional, is the more basic issue (Curtin and Talbert, 2005). Except in a handful of states, referred to by some as "topdown” planning states (Dawkins and Nelson, 2004), local government land use plans are not 
required to be consistent with state planning objectives. Moreover, zoning ordinances in the vast majority of the states are not required to be consistent with land use plans (Eschweiler, 1993).

\subsection{Metropolitan Centers And Transit-Oriented Development}

In a number of metropolitan regions undertaking collaborative growth management, a key principle has been to promote the development of metropolitan centers. These centers of higherdensity, mixed-use development are hypothesized to have a number of benefits. First, centers located near rail or bus transit can help encourage transit utilization and reduce vehicle miles in the region. Second, higher-density metropolitan centers can offer a wider range of housing options. Multifamily housing located near transit can be particularly beneficial to lower-income individuals. Third, when centers contain higher-density housing and services, it can reduce trips and travel because people are able to access retail and services locally rather than traveling long distances.

In addition to broader city and regional benefits, centers are also responding to changing market forces and market demand. There is increasing demand for multifamily housing located near amenities, with people favoring walkable places that offer shopping and dining. Millennials and Empty Nesters (adults whose children have left home) are also seeking a more urban living experience and are less interested in single-family suburban housing. Finally, many employees and employers prefer to be located in areas that offer a mix of activities and amenities.

There is extensive literature on the factors essential to successful transit-oriented development (TOD) centers. First promoted by New Urbanist designers (Calthorpe, 1993; 1000 Friends of Oregon, 1992), TOD seeks to locate higher-density, mixed-use, pedestrian-designed development proximate to high-capacity transit for the purpose of increasing transit ridership (Boarnet and Compin, 2007; Ewing and Bartholomew, 2013). In identifying the fundamental elements of TOD, a taxonomy of factors — alliteratively all beginning with " $D$ ”- - have been articulated, beginning with the " 3 Ds" of density, diversity, and design (Cervero and Kockelman, 1993). The list has now been expanded to include distance to transit, destination accessibility, demographics, and demand management (Ewing, 2010; TransLink, 2010). 


\subsection{METHODS}

This study uses a mixed-method approach to examining the policy, planning and spatial change related to collaborative metropolitan governance. Our broader goal is to increase the understanding about the strengths and weaknesses of these collaborative efforts, and identify key lessons from practice. We approach this by conducting a study of regional planning efforts in the metropolitan areas of Salt Lake City and Denver.

Our key question is whether collaborative approaches to metropolitan governance are effective in achieving results. In particular, we have focused on the concept of metropolitan centers, which is a key policy in both regions for achieving growth management goals. Ideally, this study would measure long-term outcomes or impacts, such as air quality, traffic congestion, and urban density. However, these kinds of measures require long-term monitoring to assess trends, because of compounding factors (weather variability, real estate trends, gasoline prices, economic trends) that create considerable variability. Instead, we focus on two interim outcomes. First, we are interested to see how local government land use plans and policies have changed over time and whether there is evidence to suggest that changes in local planning have been induced by regional policies, plans, investment and incentives. Second, we are interested to see how development, transportation choices and demographics have changed over time within the areas designated as metropolitan centers.

\subsection{Metropolitan Cases}

We chose the Denver and Salt Lake City metropolitan regions for several reasons. First, both regions have undertaken extensive collaborative regional growth management efforts that have been in place long enough to examine local planning responses over time. Second, both regions have promoted the concept of metropolitan centers in plans and policies. Third, both regions have invested in transit as a key policy to encourage and support development of metropolitan centers. There are also clear differences between the regions, including different definitions of centers, varying degrees of regional policy support, different rates of transit investment, and different regional governance strategies. However, comparing the experiences in two jurisdictions helps identify similarities and differences that can improve the transferability of the findings to other regions.

To understand the regional context in Denver and Salt Lake City, we analyzed plans, documents and policies at the regional level. The purpose of this review was to summarize the metropolitan centers concept in each region and document its emergence and evolution over time. As part of this review, we also examined supporting policies of the MPOs and the regional transit agencies, such as incentive programs, grants, technical support and other programs. In addition to document analysis, we interviewed staff with the regional MPOs and transit agencies in both regions. The interviews focused on clarifying the urban center policy goals and the regional efforts to support these policies. 


\subsection{Case Study Analysis}

We chose to analyze 10 case study cities near Denver and seven case study cities near Salt Lake City based on several criteria (see Table 3-1):

- Suburban cities in varying geographic positions (outer ring, inner ring, etc.)

- Cities that have designated metropolitan centers other than just a traditional downtown

- Cities with varying light rail services (established, in development, future)

- Cities of sufficient size to have a robust planning system

- Cities that have prepared plans pre- and post- the initiation of regional metropolitan planning efforts

Figure 3-1: Case Study Cities

\begin{tabular}{|l|l|l|}
\hline Denver Region & Population (2012 Census) & Location: Type \\
\hline Denver & 604,356 & Central: Central City \\
\hline Aurora & 326,249 & Southeast: Inner-ring suburb \\
\hline Arvada & 106,965 & Northwest: Outer-ring suburb \\
\hline Westminster & 106,750 & Northwest: Outer-ring suburb \\
\hline Thornton & 118,747 & North: Outer-ring suburb \\
\hline Centennial & 106,114 & Southeast: Outer-ring suburb \\
\hline Lone Tree & 10,941 & South: Outer-ring suburb \\
\hline Greenwood Village & 13,932 & South Central: Inner-ring suburb \\
\hline Lakewood & 143,496 & West: Inner-ring suburb \\
\hline Englewood & 30,565 & South: Inner-ring suburb \\
\hline Salt Lake City Region & Population (2014 Census) & Location: Type \\
\hline Salt Lake City & 189,267 & Central: Central City \\
\hline Clearfield & 30,484 & Northwest: Outer-ring suburb \\
\hline Lehi & 56,275 & South: Outer-ring suburb \\
\hline Murray & 48,822 & South: Inner-ring urban \\
\hline Pleasant View & 8,948 & Northwest: Standalone rural \\
\hline Sandy & 91,148 & South: Outer-ring urban \\
\hline South Jordan & 62,781 & Southwest: Outer-ring suburban \\
\hline
\end{tabular}

For each case, we undertook a content analysis of local plans prepared over time to identify the influence of metropolitan plans on local plans. We also interviewed planners within each jurisdiction to understand the current factors influencing local planning and development around each metropolitan region.

\subsubsection{Plan Content Analysis}

As a part of this study, the research team conducted a content analysis of the comprehensive planning documents of each case study community. The purpose of this review was to identify the extent to which concepts related to urban centers pre-dated regional plans and the extent to which local plans evolved in response to regional plans over time. The content analysis involved three steps. 
First, we identified key search terms, which fit into three distinct categories - (1) metropolitan center-related terms, (2) plan and program terms, and (3) agency terms. Example terms from each category include:

- Metropolitan Center-Related Terms: “urban center," “neighborhood center," "transit-oriented development," etc.

- Plan and Program Terms: "Metro Vision," "Wasatch Choice," "FasTracks," etc.

- Agency Terms: "DRCOG," “RTD,” “Envision Utah,” "Wasatch Choice Regional Council”

Next, the research team collected and reviewed current local government comprehensive plans and those published prior to the adoption of current regional planning efforts (Metro Vision in Denver; Envision Utah and Wasatch Choice in Salt Lake City). After scanning plans using optical recognition software, we utilized the document search tool to record "action-oriented" instances where key terms were used and investigated their context.

Third, we assigned a score to each search term using a 0-3 scale where 3 is the strongest level of use. Scoring of "metropolitan center-related terms" and "plan and program terms" focused on the extent to which a plan called for their implementation. "Agency terms" were scored based on the extent to which a plan called for cooperation and partnership on centers-related concepts.

Scoring utilized the following criteria:

- Urban Center-Related Terms/ Plan and Program Terms: -no implementation (0); weak implementation (1); medium implementation (2); strong implementation (3)

- Agency Terms: -no cooperation/ partnership (0); low cooperation/ partnership (1); medium cooperation/ partnership (2); strong cooperation/ partnership (3)

Two graduate researchers, one from the University of Oregon and one from the University of Utah, collaborated to complete the content analysis of comprehensive planning documents. The graduate researcher from the University of Oregon reviewed plans from the Denver metro region while the graduate researcher from the University of Utah focused on the Salt Lake City metropolitan region. Throughout the process, the researchers coordinated activity and reviewed one another's work in order to ensure they followed a consistent approach. Once scoring was completed, the research team began analyzing the results from both Denver and Salt Lake City.

\subsubsection{Planner Interviews}

To help with the interpretation and analysis of the local plans, we interviewed at least one planner or city official in each jurisdiction. In total, we interviewed 13 planners in the Denver region and eight planners in the Salt Lake City region. The interviews were carried out in person or by phone by members of the research team, and most interviews were recorded to ensure accuracy. The semi-structured interviews were confidential to assure participants they could speak freely about their local jurisdiction. The interviews covered:

0 The influence of regional planning on local planning

o Local implementation of the metropolitan centers concept

o Challenges or tensions with implementation 
o Perceptions about the extent to which the adoption of metropolitan center policies were influenced by regional planning, public opinion, financial incentives, market trends, transit investment or other factors

\subsubsection{GIS Analysis}

In addition to examining the changes in local government plans and policies, we also sought to assess the extent to which these changes are inducing land use change on the ground. To answer this question, we used a wide range of spatial data sets, including:

- Jurisdiction location of center

- Transit line locations

- Area in square miles

- Density (population per square mile)

- Population

- Household income (2012 \$)

- Housing units

- Vacancy rate

- Percent owner and renter

- Percent transit, bike or walk

- Percent commuting by 0 or 1 car

- Number and density of light rail and bus stations

- Number and density of cul-de-sacs

- Average block length

In order to examine the change in demographics, land use and transportation network, we rely on U.S. Census Decennial data from 2000 and 2010, and American Community Survey Data from 2008-2012. We obtained tabular data at the block-group, city and MSA level from Social Explorer and obtained GIS files from US TIGER/line. Transportation network, bus stop, and light rail data were acquired from RTD in Denver and the State of Utah in Salt Lake City. DRCOG provided Urban Center shapefiles and WFRC provided center shapefiles for all center types. Replicating methods used by the Center for Neighborhood Technology TOD Database, we also obtained center-level estimates by apportioning Census block-group data to metropolitan. (See: http://toddata.cnt.org/user-guide.php). A step-by-step summary of this analysis process is provided in Appendix B.

\subsubsection{Center Selection}

In selecting centers for analysis, we chose to focus on those served by rail that have been established long enough to potentially experience land use change. In particular, the Denver region has a number of stations that have opened within the past year or two. We also attempted to include centers falling in different types of settings: greenfield, mixed and existing.

In the Denver region, as of 2014, there were 104 centers. Of these 104 centers, 71 are in our case study cities. For GIS analysis, we selected 12 centers within our case study centers. Table 3-1 and Table 3-2 convey basic information about all centers within our case study cities and 
highlight the centers chosen for GIS analysis. We selected several centers from the Central line and Southwest line, which opened in 1994 and 2006, respectively. We were limited to considering centers in certain cities because of the lack of transit stations open by 2014 as well as the lack of easily obtainable GIS data for Jefferson County.

Table 3-1: Case Study Centers in DRCOG region

\begin{tabular}{|c|c|c|c|c|}
\hline City & Name & $\begin{array}{l}\text { Area (Square } \\
\text { Miles) }\end{array}$ & $\begin{array}{l}\text { DRCOG } \\
\text { Typology }\end{array}$ & $\begin{array}{c}\text { Existing and } \\
\text { Planned Light Rail } \\
\text { Stations }\end{array}$ \\
\hline \multirow{3}{*}{ Arvada } & Candelas & 0.99 & Emerging & 0 \\
\hline & Olde Town/New Town & 0.25 & Existing & 1 \\
\hline & Ralston Fields & 0.40 & Existing & 1 \\
\hline \multirow{17}{*}{ Aurora } & 13th Avenue & 0.28 & Emerging & 1 \\
\hline & 1st Avenue Center & 0.53 & Existing & 0 \\
\hline & 56th Avenue & 0.32 & Planned & 0 \\
\hline & Airport Gateway & 0.06 & Planned & 1 \\
\hline & Aurora City Center & 1.36 & Emerging & 2 \\
\hline & Buckingham Center & 0.65 & Existing & 0 \\
\hline & Colfax Avenue & 0.52 & Existing & 0 \\
\hline & E-470 / I-70 & 1.63 & Emerging & 0 \\
\hline & Fitzsimons & 1.28 & Emerging & 2 \\
\hline & Florida & 0.39 & Existing & 1 \\
\hline & Hampden Town Center & 0.16 & Emerging & 1 \\
\hline & I-225/Parker Road & 0.33 & Emerging & 1 \\
\hline & liff & 0.29 & Existing & 1 \\
\hline & Iliff Avenue Center & 0.49 & Emerging & 0 \\
\hline & Jewell Avenue & 0.46 & Emerging & 0 \\
\hline & Peoria - Smith & 0.42 & Emerging & 0 \\
\hline & Smoky Hill & 0.59 & Emerging & 0 \\
\hline Centennial & Southglenn & 0.23 & Existing & 0 \\
\hline Englewood & Englewood City Center & 0.10 & Emerging & 1 \\
\hline \multirow{5}{*}{ Lakewood } & Denver West/CO Mills Center & 0.85 & Existing & 0 \\
\hline & Lakewood Center & 0.45 & Emerging & 0 \\
\hline & Oak Street & 0.45 & Existing & 1 \\
\hline & Union Center & 1.00 & Emerging & 1 \\
\hline & Wadsworth Boulevard & 0.46 & Existing & 1 \\
\hline \multirow{3}{*}{ Lone Tree } & Lincoln Station TOD & 0.10 & Emerging & 1 \\
\hline & Ridge Gate West Village & 0.59 & Emerging & 1 \\
\hline & RidgeGate City Center & 0.30 & Emerging & 1 \\
\hline $\begin{array}{c}\text { Centennial, Greenwood } \\
\text { Village, Denver, Lone } \\
\text { Tree }\end{array}$ & I-25 Corridor & 9.27 & Emerging & 4 \\
\hline \multirow{4}{*}{ Thornton } & Eastlake & 0.16 & Emerging & 1 \\
\hline & I-25 / Hwy 7 Activity Center & 0.78 & Emerging & 0 \\
\hline & North End Station & 0.20 & Emerging & 1 \\
\hline & Thornton City Center & 0.77 & Existing & 0 \\
\hline
\end{tabular}


Table 3-2: Centers in Case Study Centers in DRCOG region (Continued)

\begin{tabular}{|c|c|c|c|c|}
\hline City & NAME & $\begin{array}{l}\text { Area (Square } \\
\text { Miles) }\end{array}$ & $\begin{array}{l}\text { DRCOG } \\
\text { Typology }\end{array}$ & $\begin{array}{l}\text { Number of Existing } \\
\text { and Planned Light } \\
\text { Rail Stations }\end{array}$ \\
\hline \multirow{31}{*}{ Denver } & 10th \& Osage Station & 0.27 & Existing & 1 \\
\hline & 29th Ave. Town Center & 0.14 & Emerging & 0 \\
\hline & 38th and Blake TOD & 0.37 & Emerging & 2 \\
\hline & 41st and Fox TOD & 0.49 & Existing & 1 \\
\hline & 62nd and Pena TOD & 0.25 & Emerging & 0 \\
\hline & Alameda Station & 0.31 & Emerging & 1 \\
\hline & Bear Valley & 0.13 & Existing & 0 \\
\hline & Belleview Station & 0.12 & Emerging & 1 \\
\hline & Broadway & 0.22 & Existing & 0 \\
\hline & Broadway Station TOD & 0.23 & Emerging & 1 \\
\hline & Central Business District & 2.66 & Emerging & 11 \\
\hline & Central Park TOD & 0.10 & Emerging & 1 \\
\hline & Cherry Creek & 0.94 & Existing & 0 \\
\hline & Colorado Blvd and Smith Road & 0.12 & Emerging & 1 \\
\hline & Colorado Blvd Health Care Dist & 0.21 & Emerging & 0 \\
\hline & Colorado Station & 0.27 & Existing & 1 \\
\hline & Decatur - Federal TOD & 0.44 & Existing & 1 \\
\hline & Denargo Market & 0.18 & Emerging & 0 \\
\hline & Denver Technology Center & 0.45 & Emerging & 0 \\
\hline & DU Campus Urban Center & 0.32 & Existing & 1 \\
\hline & East Colfax Main Street & 0.87 & Existing & 0 \\
\hline & Evans Station TOD & 0.18 & Existing & 1 \\
\hline & Federal and Evans & 0.24 & Existing & 0 \\
\hline & Lowry Town Center & 0.19 & Existing & 0 \\
\hline & MLK Town Center & 0.04 & Planned & 0 \\
\hline & Pena \& 40th & 0.08 & Planned & 0 \\
\hline & Sheridan Station & 0.26 & Emerging & 1 \\
\hline & Southmoor Park TOD & 0.08 & Emerging & 1 \\
\hline & St. Anthony's Urban Center & 0.05 & Emerging & 0 \\
\hline & Stapleton North Regional Cen & 0.52 & Emerging & 0 \\
\hline & Tamarac \& Hampden & 0.12 & Existing & 0 \\
\hline \multirow{5}{*}{ Westminster } & North I-25 Activity Center & 0.88 & Emerging & 0 \\
\hline & S Westminster Activity Center & 0.36 & Emerging & 1 \\
\hline & West 120th Ave Activity Ctr & 0.92 & Existing & 0 \\
\hline & Westminster Ctr Activity Ctr & 0.97 & Emerging & 1 \\
\hline & Westminster Promenade Act Ctr & 0.84 & Emerging & 2 \\
\hline
\end{tabular}

As of 2016, there were 109 centers in the Salt Lake Region, 24 of which are in our case study centers. For GIS analysis, we selected 16 centers (shaded in tan.) Table 3-3 conveys basic information about all centers within our case study cities and highlights the centers chosen for GIS analysis. In the Salt Lake region, we selected several cases from the Blue, Green and Red lines, which opened between 2000 and 2013. We selected centers with transit from the case studies identified below in addition to three centers planned for transit. 
Table 3-3: Centers in Case Study Centers in WFRC region

\begin{tabular}{|c|c|c|c|c|}
\hline City & Name & $\begin{array}{c}\text { Area in } \\
\text { Square } \\
\text { Miles }\end{array}$ & WFRC Typology & Number of Stations \\
\hline \multirow{2}{*}{ Clearfield } & Layton & 3.76 & Urban Center & 1 \\
\hline & CRT 1400 S 800 E Clearfield & 0.20 & Station Community & 1 \\
\hline \multirow{3}{*}{ Lehi } & Cabellas Core & 1.46 & Urban Center & 0 \\
\hline & No Name 7151 & 0.20 & Station Community & 0 \\
\hline & No Name 7353 & 0.20 & Station Community & 0 \\
\hline \multirow{5}{*}{ Murray } & Murray & 2.16 & Urban Center & 2 \\
\hline & LRT 72 w Fireclay Ave & 0.20 & Station Community & 1 \\
\hline & 700 West Midvale & 0.35 & Main Street Community & 0 \\
\hline & State, 33rd to 45 th & 0.43 & Boulevard Community & 0 \\
\hline & State, Murray & 0.39 & Boulevard Community & 0 \\
\hline Pleasant View & CRT Pleasant View & 0.47 & Town Center & 1 \\
\hline \multirow{7}{*}{ Salt Lake City } & Foothill Blvd & 0.64 & Boulevard Community & 0 \\
\hline & LRT 825 W North Temple & 0.20 & Station Community & 1 \\
\hline & LRT 1100 W North Temple & 0.20 & Station Community & 1 \\
\hline & LRT 1500 W North Temple & 0.20 & Station Community & 1 \\
\hline & LRT 1900 W North Temple & 0.20 & Station Community & 1 \\
\hline & Salt Lake Core & 5.11 & Metropolitan Center & 15 \\
\hline & Sugar House & 0.53 & Town Center & 0 \\
\hline \multirow{2}{*}{ Sandy } & Sandy CBD & 2.35 & Urban Center & 3 \\
\hline & State, Sandy & 0.70 & Boulevard Community & 0 \\
\hline \multirow{4}{*}{ South Jordan } & 106th S, SJ & 0.46 & Boulevard Community & 0 \\
\hline & Daybreak & 1.50 & Urban Center & 2 \\
\hline & Daybreak U-111 & 0.55 & Town Center & 0 \\
\hline & No Name 9875 & 0.20 & Station Community & 0 \\
\hline
\end{tabular}

\subsubsection{Limitations of GIS Analysis}

It is important to note several limitations of the GIS analysis. First, because we attempted to use consistent data sources across metropolitan areas, we were limited to using Census data. Because Census data represented 2000 and 2010, we face recession-era impacts as 2000 was the height of the tech bubble and 2010 was the bottom of the recession. Including data from 2010-2015 would likely yield different results.

Second, we face spatial aggregation issues. Because Census block groups do not match center boundaries, we had to clip and aggregate data to center boundaries. Additionally, Census geographies sometimes change over time. To ensure that noise in the data was not affecting results, we used visual inspection of Census boundaries and noticed that boundaries changed little in most places. Further, we asked planners at DRCOG and WFRC to verify results for accuracy.

Finally, while we intended to include additional analysis based on employment data and parcel data, data acquisition and aggregation efforts proved infeasible. We intend to explore these aspects in future work. 



\subsection{DENVER REGION}

\subsection{Denver Regional Council of Governments}

Situated along the Front Range of Colorado, the Denver Regional Council of Government's (DRCOG) planning area encompasses nine counties and 48 cities, including Denver, Boulder, Aurora, and Lakewood. The regional population is approximately 2.8 million people, with over 600,000 living in the city of Denver (DRCOG, 2009, 2).

DRCOG is a nonprofit, voluntary association of local governments created in the 1950s to address concerns about regional growth, transportation planning and development. DRCOG is a public agency, but does not have statutory authority to require local governments or members to follow its plans; nor can it tax, issues bonds or legislate (DRCOG, 2016a). DRCOG created its first Metro Growth Plan in 1961, followed by a Regional Growth and Development Plan in 1978 and a Regional Development Framework in 1985. Since 1997, regional plans developed by DRCOG have been known as Metro Vision (DRCOG, 2016b).

DRCOG is overseen by a Board of Directors consists of representatives from the 56 participating local governments (nine counties and 48 cities). The governor also appoints three non-voting representatives to the Board of Directors. DRCOG utilizes a committee structure to support its work, including a Regional Transportation Committee and a Metro Vision Issues Committee. The majority of DCROG's revenue comes from federal sources (65\% in 2015), with the remainder coming from state sources, local funds, member dues, and service income (DRCOG, 2015).

\subsection{Metro Vision and Transportation Planning}

The DRCOG Board of Directors adopted the first Metro Vision plan (Metro Vision 2020) in 1997. Metro Vision was described as a "Shared vision of the future of the metro area to make life better for residents” (DRCOG, 2000, 2), and it emerged out of concerns about rapid growth, quality of life and increasing infrastructure costs. A 2005 update extended the planning horizon to 2030 and the most recent plan extends the planning time frame to 2035 (DRCOG, 2007). The plan is founded on six key principles:

- Protecting and enhancing the region's quality of life

- Providing a regional direction for helping local governments to coordinate

- Respecting local plans

- Encouraging communities to work together

- Offering Metro Vision as a dynamic and flexible plan

The plan addresses development, transportation needs, and environmental quality in the region by providing a foundation for regional planning and local decision-making. It includes components related to urban development, metropolitan, community design, and parks and open space (DRCOG, 2011). 
Figure 4-1: Denver Metropolitan Region

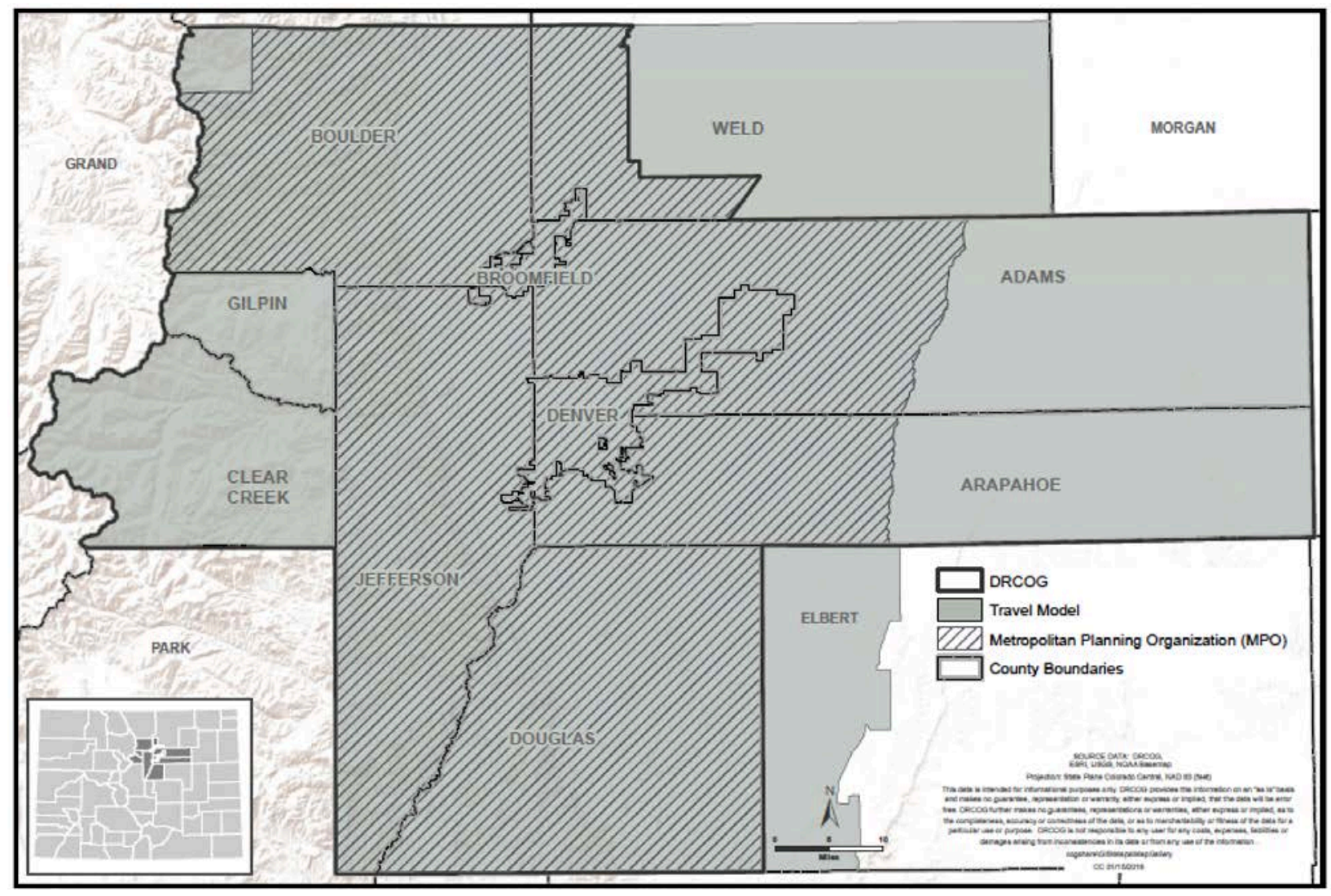

Metro Vision is also supported by regional transportation planning, which is carried out by DRCOG under its authority as the federal MPO. These components are also integrated into regional transportation planning and transportation investment decision making (DRCOG, 2011).

As a federal MPO, DRCOG is responsible for regional transportation planning through its 2035 Metro Vision Regional Transportation Plan and regional Transportation Improvement Program (TIP) (2035 Metro Vision RTP). The Regional Transportation Plan is a multimodal plan for the region necessary to respond to future growth and to influence how the growth occurs. It specifies strategies, policies, and major capital improvements that advance the objectives of the Metro Vision 2035 Plan (DRCOG, 2010). Before a regionally significant transportation project can be included in the TIP, it must first be recognized in the Regional Transportation Plan. That plan conforms with the State Implementation Plan for air quality and must meet certain criteria of the Metro Vision Policies (DRCOG, 2007, p. 86)

\subsubsection{Scenario Planning}

The current version of the Metro Vision 2035 plan was built on an extensive scenario planning carried out for the 2020 plan. The process examined a range of planning and development scenarios, which were examined against impacts such as open space, habitat and vehicle miles traveled. The scenario plans were influential in highlighting some of the significant problems with the existing development trends and patterns (see inset below). 


\section{Metro Vision 2020 Scenario Planning (Bartholomew, 2005)}

The Metro Vision 2020 process began with a statement of vision and principles aimed at better accommodating the 900,000 new residents expected by 2020 through the development of an integrated long-range regional development and transportation plan. The project used four archetypical scenarios to assess the impacts of thematically different development patterns:

Current Trends: the expected land use pattern that would result from implementing current development policy and existing market conditions.

Compact Development: most growth would locate on infill development sites within the central city and existing suburbs.

Satellite Cities: growth would be channeled to existing satellite communities or new planned communities, physically separated from the central urban area by open space or undeveloped land.

Corridor Development: growth would be located along major transportation routes, especially transit lines. After these four scenarios were analyzed, a compromise Metro Vision option was crafted and adopted. This "scenario" was not presented as a detailed potential allocation of households and jobs-as the other scenarios were-but as a statement of six primary principles. The only geographically specific element in the plan was the regional urban growth boundary (which was set at 747 square miles). Subsequently, an open spaces plan was prepared that gave a general geographic focus to the Metro Vision open spaces element. Transportation investments were altered to reflect the land use patterns of each scenario.

\section{The Evaluation Process}

The scenarios were analyzed according to 25 criteria, classified into five major categories: land use, transportation, environment, open space, and implementation. These measures were derived from the statement of policies and principles made by the sponsor in an earlier phase of the project.

The project initially analyzed 11 urban form scenarios using qualitative evaluation criteria. Based on this analysis, four scenarios were crafted for more in-depth analysis. The analysis used GIS for many of the land use assessments and the regional transportation modeling system to assess transportation and air quality impacts. In addition, a number of other ad hoc measurement tools were used.

Of particular interest was the project's measurement of the implementability of each scenario, as influenced by the degree of acceptance by local officials. To do this, the staff measured the degree to which each scenario was consistent with a regional composite of the existing local plans, and asked local government planners to select the scenario they estimated was closest to local plans. 


\section{Evaluation Results}

\begin{tabular}{|l|l|l|l|l|}
\hline & Dcenarios & $\begin{array}{l}\text { \% of } \\
\text { Congested } \\
\text { VMT }\end{array}$ & $\begin{array}{l}\text { Wildlife Habitat } \\
\text { Consumed } \\
\text { (sq. mi.) }\end{array}$ & $\begin{array}{l}\text { Annual Additional } \\
\text { Water Needed } \\
\text { (ac-ft/yr) }\end{array}$ \\
\hline \hline Dispersed (Current Trends) & $73,900,000$ & $41 \%$ & 181.8 & 127,010 \\
\hline Compact Development & $64,700,000$ & $59 \%$ & 71.8 & 110,789 \\
\hline Satellite Cities & $66,600,000$ & $54 \%$ & 97.4 & 94,728 \\
\hline Corridor Development & $68,600,000$ & $55 \%$ & 109.7 & 117,806 \\
\hline
\end{tabular}

The analysis showed the Dispersed Scenario to be the most automobile oriented, land consumptive, and air polluting of the four scenarios. It also, however, had the lowest levels of traffic congestion and was deemed the easiest to implement. The Compact scenario was the best at promoting alternative mode use and was the most land efficient, but it had the highest level of traffic congestion and the lowest ranking for providing housing close to jobs. According to the region's 2002 long-range transportation plan, three broad themes were evident from the analysis:

- The Dispersed Alternative was undesirable for a number of reasons, including cost, land consumption, increased VMT and environmental impacts.

- The Compact Alternative was judged to have the lowest cost and minimized the environmental impacts of future growth, but could encounter public resistance to strategies that increased density and mixed-use development to the extent assumed in this alternative.

- Any strategy to reduce VMT, increase transit use and improve air quality needs to be a combination of land use, transportation and other measures."

\section{Elected Official Participation/Public Involvement}

After the initial eleven alternatives were developed, a public opinion survey, open house meetings, and 2 workshop events were held in which "several hundred citizens and government, business, and environmental leaders" (p.vii) were involved. The Vision 2020 Task Force then selected the 4 scenarios. DRCOG adopted the Metro Vision Framework in 1997. Given the agency's council of government structure, local elected official participation is assumed.

\section{Resulting Actions}

The Metro Vision process led to the development of a regional open spaces plan and the creation of the Mile High Compact, through which a majority of the local governments in the region committed to adopt policies and amendments to planning and zoning documents consistent with the Metro Vision Framework. Projects included in the 2002 long-range transportation plan were designed to be consistent with the Metro Vision Framework. However, the land use forecast for the region does not appear to have been affected by Metro Vision.

DRCOG is presently working to update Metro Vision, and, among other things, extend its range to 2035. In the meantime, the city of Denver has taken the lead in implementing Metro Vision by adopting its Blueprint Denver integrated land use and transportation plan. Through this plan, the city has brought geographic specificity to the policy elements of Metro Vision, and has established a list of specific implementing actions designed to make Metro Vision a reality. 


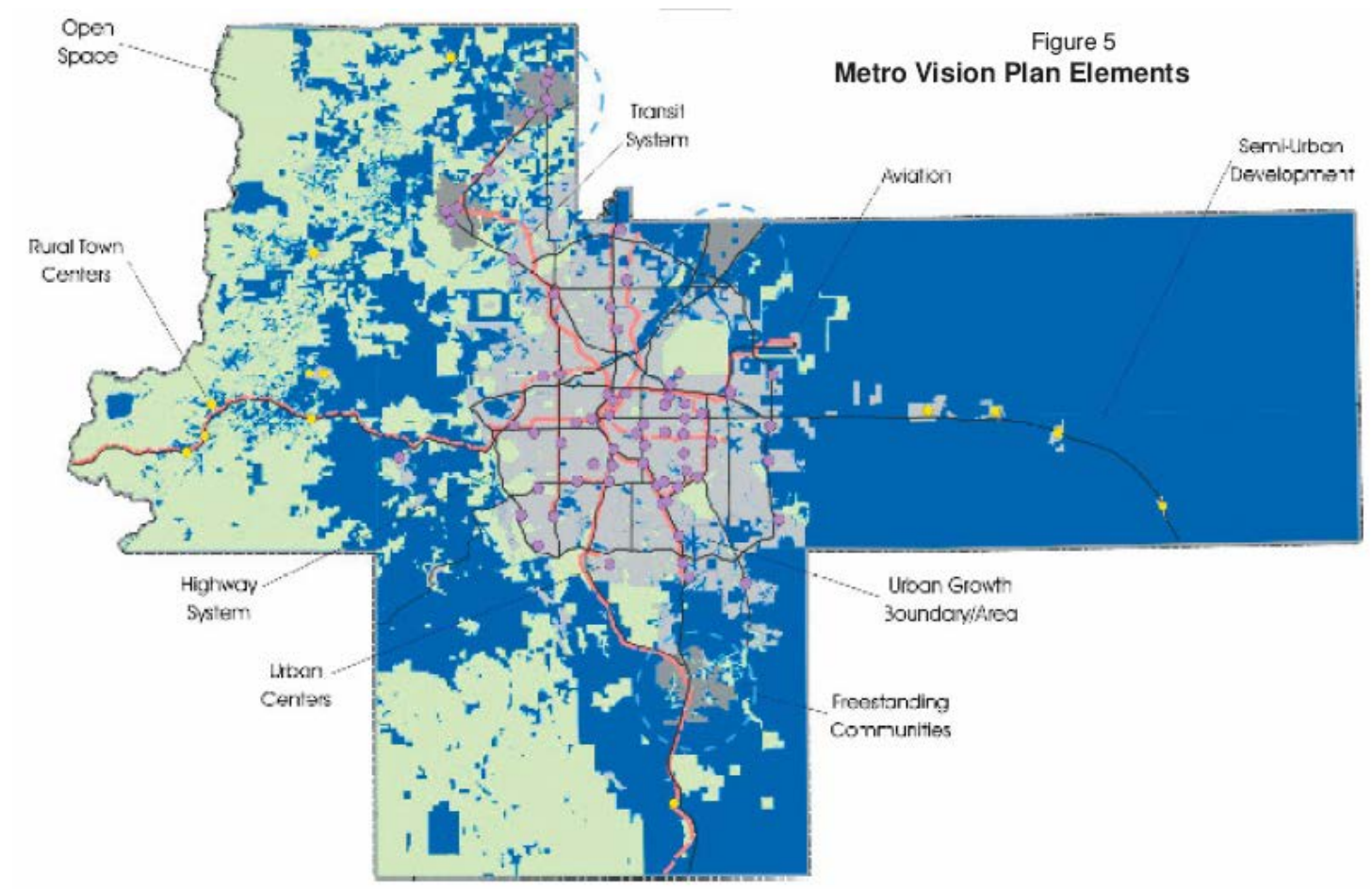

\subsubsection{Current Centers Policies}

Since its inception, a key implementation strategy of Metro Vision has been the promotion of centers of higher density that help support transit and help reduce transportation demand by providing local retail and services. DRCOG's Metro Vision 2035 outlines the formation of urban centers, rural town centers, and freestanding communities for the purpose of decreasing urban sprawl and increasing infill. The goals of urban centers are:

- Create areas that are more dense and mixed in use than surrounding areas and supportive of active, pedestrian-, bicycle- and transit-friendly design;

- Allow people of all ages, incomes and abilities to access a range of housing, employment and services;

- Promote regional sustainability by reducing per capita vehicle miles traveled, air pollution, greenhouse gas emissions and water consumption; and

- Respect and support existing neighborhoods (DRCOG, 2011, p. 17)

The DRCOG board has established a goal of locating 50\% of all new housing units and 75\% of all new jobs in regionally designated urban centers between 2005 and 2035. To support this goal, DRCOG has allocated TIP funding to assist local governments in developing smaller area plans for station areas and urban centers. (Source: https://www.drcog.org/planning-greatregion/implementing-metro-vision/station-area-and-urban-center-planning-funds). Projects seeking approval through the TIP program are evaluated and ranked across a range of criteria. Over the years, DRCOG has allocated a percentage of criteria to supporting Metro Vision, signing the Mile High Compact and proposing projects that support designated centers (Margerum et al., 2011). 
DRCOG also works collaboratively with local governments and the Regional Transit District (RTD) in developing transit-oriented developments (TODs). The development of TODs goes hand-in-hand with the implementation of FasTracks throughout the region, which is a taxpayerfunded RTD program to rapidly increase the amount of transit services (light rail and bus rapid transit, or BRT) in the region (DRCOG, 2009, p. 6). DRCOG has assembled resources, held workshops for developers and planners, and developed online forums to assist local governments and their communities consider how they might develop centers locally. DRCOG was also awarded a \$4.5 million Sustainable Communities Initiative grant from the federal government to help support investment around rail lines being built as part of FasTracks. (Source:

https://www.drcog.org/planning-great-region/implementing-metro-vision/transit-orienteddevelopment)

\subsection{Denver Area Case Study Cities}

To examine how the regional plans and policies related to metropolitan centers have translated to the local level, we selected 10 cities for detailed analysis. As noted in the methods section, the goal in selecting these cities was to choose cases that:

- Represented a cross section of jurisdictions

- Had prepared several generations of plans so we could assess plan changes over time

- Contained designated centers in the regional plan

In the sections below, we summarize some of the key characteristics of each case study city, including its history related to planning and expansion of the region's light rail system. 
Figure 4-2: Demographic Summary (Denver Region)

\begin{tabular}{|c|c|c|c|c|c|c|}
\hline City & $\begin{array}{c}\text { Per } \\
\text { Capita } \\
\text { Income }^{1}\end{array}$ & $\begin{array}{c}\text { Median Home } \\
\text { Value (Owner } \\
\text { Occupied units) }\end{array}$ & $\begin{array}{c}\text { Below } \\
\text { Poverty Line } \\
\text { (Families) }^{3}\end{array}$ & $\begin{array}{c}\text { White } \\
\text { Alone }^{4}\end{array}$ & $\begin{array}{l}\text { Black or African } \\
\text { American Alone }\end{array}$ & $\begin{array}{l}\text { Hispanic or } \\
\text { Latino }^{5}\end{array}$ \\
\hline Denver & $\$ 34,423$ & $\$ 257,500$ & $13.7 \%$ & $68.9 \%$ & $10.2 \%$ & $31.8 \%$ \\
\hline Aurora & $\$ 24,732$ & $\$ 179,300$ & $12.3 \%$ & $61.1 \%$ & $15.8 \%$ & $28.7 \%$ \\
\hline Arvada & $\$ 34,312$ & $\$ 245,300$ & $6.0 \%$ & $89.8 \%$ & $0.9 \%$ & $13.7 \%$ \\
\hline Westminster & $\$ 31,694$ & $\$ 225,300$ & $7.8 \%$ & $82.0 \%$ & $1.4 \%$ & $20.7 \%$ \\
\hline Thornton & $\$ 26,782$ & $\$ 210,600$ & $7.1 \%$ & $77.4 \%$ & $1.8 \%$ & $31.7 \%$ \\
\hline Centennial & $\$ 41,356$ & $\$ 296,800$ & $3.5 \%$ & $87.3 \%$ & $3.3 \%$ & $7.4 \%$ \\
\hline Lone Tree & $\$ 58,941$ & $\$ 471,400$ & $4.5 \%$ & $87.2 \%$ & $1.6 \%$ & $6.2 \%$ \\
\hline Greenwood Village & $\$ 81,771$ & $\$ 769,400$ & $3.2 \%$ & $87.7 \%$ & $1.6 \%$ & $4.5 \%$ \\
\hline Lakewood & $\$ 31,689$ & $\$ 242,200$ & $9.0 \%$ & $82.9 \%$ & $1.6 \%$ & $22.0 \%$ \\
\hline Englewood & $\$ 28,814$ & $\$ 216,800$ & $13.5 \%$ & $84.4 \%$ & $2.2 \%$ & $18.1 \%$ \\
\hline
\end{tabular}

\footnotetext{
${ }^{1}$ Social Explorer Tables: ACS 2010 to 2014 (5-Year Estimates)(SE), ACS 2010 -- 2014 (5-Year Estimates), Social Explorer; U.S. Census Bureau (SE:T83. Per Capita Income (In 2014 Inflation Adjusted Dollars)

2 Social Explorer Tables: ACS 2010 to 2014 (5-Year Estimates)(SE), ACS 2010 -- 2014 (5-Year Estimates), Social Explorer; U.S. Census Bureau (SE:T101. Median House Value For All Owner-Occupied Housing Units)

3 Social Explorer Tables: ACS 2010 to 2014 (5-Year Estimates)(SE), ACS 2010 -- 2014 (5-Year Estimates), Social Explorer; U.S. Census Bureau (SE:T113. Poverty Status In 2012 Of Families By Family Type By Presence Of Children Under 18 Years)

${ }^{4}$ Social Explorer Tables (SE), Census 2010, Census Bureau; Social Explorer (SE:T54 Race)

${ }^{5}$ Social Explorer Tables (SE), Census 2010, Census Bureau; Social Explorer (SE:T55 Hispanic Or Latino Origin By Race)
} 
Figure 4-3: Case Study Community Overview (Denver Region)

\begin{tabular}{|c|c|c|c|c|}
\hline $\begin{array}{l}\text { Population } \\
(2014)^{6}\end{array}$ & $\begin{array}{c}\text { Growth Rate } \\
\text { by Decade } 6,7,8,9\end{array}$ & Location & Transit & $\begin{array}{c}\text { Comp. Plan } \\
\text { Updates }\end{array}$ \\
\hline $\begin{array}{l}\text { Denver } \\
633,777\end{array}$ & $\begin{array}{lll}1990 & 467,610 & \\
2000 & 554,636 & 18.6 \% \\
2010 & 600,158 & 8.2 \% \\
2014 & 633,777 & 4.4 \%\end{array}$ & $\begin{array}{l}\text { Central } \\
\text { Central City }\end{array}$ & \begin{tabular}{|l|}
$-3,120$ bus stops \\
-94 bus routes \\
-14 park and rides \\
-37 current and future rail stations
\end{tabular} & $\begin{array}{l}1989 \\
2000 \\
\text { Neighborhood plans }\end{array}$ \\
\hline $\begin{array}{l}\text { Aurora } \\
339,480\end{array}$ & $\begin{array}{lll}1990 & 222,103 & \\
2000 & 276,393 & 24.4 \% \\
2010 & 325,078 & 17.6 \% \\
2014 & 339,480 & 5.6 \% \\
\end{array}$ & $\begin{array}{l}\text { Southeast } \\
\text { Outer-ring } \\
\text { suburb }\end{array}$ & $\begin{array}{l}-1,037 \text { bus stops } \\
-34 \text { bus routes } \\
-4 \text { park and rides } \\
-1 \text { current }+1 \text { future light rail line } \\
-10 \text { current and future rail stations }\end{array}$ & $\begin{array}{l}1998 \\
2003 \\
2009\end{array}$ \\
\hline $\begin{array}{l}\text { Arvada } \\
109,800\end{array}$ & $\begin{array}{lll}1990 & 89,235 & \\
2000 & 102,153 & 14.5 \% \\
2010 & 106,433 & 4.2 \% \\
2014 & 109,800 & 3.2 \% \\
\end{array}$ & $\begin{array}{l}\text { Northwest } \\
\text { Outer-ring } \\
\text { suburb }\end{array}$ & \begin{tabular}{|l|}
-13 bus routes \\
-303 bus stops \\
-2 park and rides \\
-1 future light rail line +2 stations
\end{tabular} & $\begin{array}{l}1985 \\
1995 \\
2005 \\
2014\end{array}$ \\
\hline $\begin{array}{l}\text { Westminster } \\
109,296\end{array}$ & 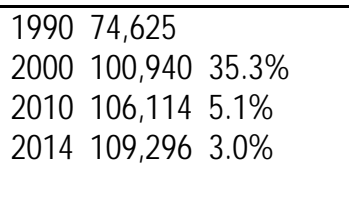 & $\begin{array}{l}\text { Northwest } \\
\text { Outer-ring } \\
\text { suburb }\end{array}$ & $\begin{array}{l}\text { - } 27 \text { bus routes } \\
-362 \text { bus stops } \\
-3 \text { park and rides } \\
-1 \text { future rail line }+4 \text { stations } \\
\text { - } 1 \text { future BRT line }\end{array}$ & $\begin{array}{l}1997 \\
2004 \text { (2008 update) } \\
2014\end{array}$ \\
\hline $\begin{array}{l}\text { Thornton } \\
124,707\end{array}$ & $\begin{array}{lll}1990 & 55,031 & \\
2000 & 82,384 & 49.7 \% \\
2010 & 118,772 & 44.2 \% \\
2014 & 124,707 & 5.0 \% \\
\end{array}$ & $\begin{array}{l}\text { North } \\
\text { Outer-ring } \\
\text { suburb }\end{array}$ & $\begin{array}{l}-17 \text { bus routes } \\
-218 \text { bus stops } \\
-1 \text { park and ride } \\
-1 \text { future light rail line }+5 \text { stations }\end{array}$ & $\begin{array}{l}1985 \\
1997 \text { (2003 update) } \\
2007 \\
2012\end{array}$ \\
\hline $\begin{array}{l}\text { Centennial } \\
104,213\end{array}$ & $\begin{array}{ll}1990 & N A \\
2000 & N A \\
2010 & 100,377 \\
2014 & 104,213 \quad 3.8 \%\end{array}$ & $\begin{array}{l}\text { Southeast } \\
\text { Outer-ring } \\
\text { suburb }\end{array}$ & $\begin{array}{l}\text { - } 13 \text { bus routes } \\
-185 \text { bus stops } \\
-1 \text { park and ride } \\
-1 \text { light rail line }+0 \text { stations }\end{array}$ & 2004 \\
\hline $\begin{array}{l}\text { Lone Tree } \\
12,328\end{array}$ & $\begin{array}{lll}1990 & N A & \\
2000 & 4,873 & \\
2010 & 10,218 & 109.7 \% \\
2014 & 12,328 & 20.6 \% \\
\end{array}$ & $\begin{array}{l}\text { South } \\
\text { Outer-ring } \\
\text { suburb }\end{array}$ & $\begin{array}{l}-6 \text { bus routes } \\
-30 \text { bus stops } \\
-1 \text { light rail line } \\
-1 \text { current }+3 \text { future rail stations }\end{array}$ & $\begin{array}{l}1996 \\
2008\end{array}$ \\
\hline $\begin{array}{l}\text { Greenwood } \\
\text { Village } \\
14,456\end{array}$ & $\begin{array}{lll}1990 & 7,589 & \\
2000 & 11,035 & 45.4 \% \\
2010 & 13,925 & 26.2 \% \\
2014 & 14,456 & 3.8 \%\end{array}$ & $\begin{array}{l}\text { South Central } \\
\text { Inner-ring } \\
\text { suburb }\end{array}$ & \begin{tabular}{|l|} 
- 11 bus routes \\
-96 bus stops \\
-3 park and rides \\
-3 light rail lines +2 stations
\end{tabular} & $\begin{array}{l}2004 \text { (updated in } \\
\text { 2012) }\end{array}$ \\
\hline $\begin{array}{l}\text { Lakewood } \\
145,880\end{array}$ & $\begin{array}{lll}1990 & 126,481 & \\
2000 & 144,126 & 14.0 \% \\
2010 & 142,980 & -0.8 \% \\
2014 & 145,880 & 2.0 \%\end{array}$ & $\begin{array}{l}\text { West } \\
\text { Inner-ring } \\
\text { suburb }\end{array}$ & $\begin{array}{l}-692 \text { bus stops } \\
-32 \text { bus routes } \\
-3 \text { park and rides } \\
-1 \text { light rail line }+7 \text { stations }\end{array}$ & $\begin{array}{l}1987 \\
1997 \\
2003 \\
2015\end{array}$ \\
\hline $\begin{array}{l}\text { Englewood } \\
31,298\end{array}$ & $\begin{array}{lll}1990 & 29,387 & \\
2000 & 31,727 & 8.0 \% \\
2010 & 30,255 & -4.6 \% \\
2014 & 31,298 & 3.4 \%\end{array}$ & $\begin{array}{l}\text { South } \\
\text { Inner-ring } \\
\text { suburb }\end{array}$ & $\begin{array}{l}-13 \text { bus routes } \\
-114 \text { bus stops } \\
-1 \text { park and ride } \\
-1 \text { light rail line }+1 \text { station }\end{array}$ & $\begin{array}{l}1979 \\
2003 \\
2015\end{array}$ \\
\hline
\end{tabular}

\footnotetext{
${ }^{6}$ Social Explorer Tables: ACS 2014 (5-Year Estimates)(SE), ACS 2014 (5-Year Estimates), Social Explorer; U.S. Census Bureau (SE:T1 Total Population)

${ }^{7}$ Social Explorer Tables(SE), Census 1990, Census Bureau; Social Explorer (SE:T1 Total Population)

${ }^{8}$ Social Explorer Tables(SE), Census 2000, Census Bureau; Social Explorer (SE:T1 Total Population)

${ }^{9}$ Social Explorer Tables(SE), Census 2010, Census Bureau; Social Explorer (토:T1 Total Population)
} 


\subsubsection{Denver}

Denver is the largest city in and the capital of Colorado. The city was founded in 1858 as a mining town known as Denver City. The city and county of Denver occupy the same geographic space, covering 155 square miles. As of 2014, the population was estimated to be 633,777 (Social Explorer, 2014).

Denver is built on a grid pattern with narrow blocks. As its west it expanded along its extensive streetcar system, which reached its height in 1893. Over the past 60 years, development moved from the urban areas of the central business district to the inner-ring suburbs south along I-25 and east along Colfax Avenue. Denver uses a number of different types of plans depending on the geography specified. These plans range from citywide plans and initiatives to small area plans and general development plans. The city is currently guided by the 2000 Comprehensive Plan and an integrated land use and transportation plan entitled Blueprint Denver.

Denver is currently experiencing an increased rate of infill development following years of lowdensity, auto-oriented development. Much of the infill and redevelopment in Denver is occurring on the northeast side of the city in areas such as Lowry, Stapleton, and the Denver International Airport. Surrounded by incorporated suburbs on all sides, Denver is entirely landlocked. This has led the city to place a strong focus on infill development. The majority of infill development is taking place around newly developed commuter rail stations and along the I-70 corridor.

\subsubsection{Aurora}

The city of Aurora incorporated in 1891 as the town of Fletcher. Originally just four square miles, Aurora is now the third-largest city in Colorado. Today, Aurora is approximately 154 square miles and home to 339,480 residents (Social Explorer, 2014).

Older sections of Aurora feature traditional town planning - narrow lots with streets based on a grid pattern. As the city grew to the south and east, the development pattern became increasingly suburban. Post-war subdivisions have curvilinear residential streets, cul-de-sacs and strip commercial development along arterial roads. Due to rapid growth during this period, the majority of Aurora's housing stock was built during the 1970s and 1980s.

Aurora's first comprehensive plan was adopted in 1973. More recent plans include the 1998, 2003, and 2009 comprehensive plans. The 1998 Aurora Comprehensive Plan established "a framework for neighborhood design” calling for localized activity centers (City of Aurora Comprehensive Plan, 2009). The 2003 Comprehensive Plan expanded on the concept by calling for urban centers across the city, especially where transit access is available. Light rail reached Aurora when the Southeast Rail Line opened two stations in 2006 - the Dayton Street Station and Nine Mile Station. Since 2007, the city has been preparing a series of station area plans for Aurora's existing and planned light rail passenger stations.

A considerable amount of redevelopment and infill is currently taking place in Aurora. The majority of this new growth is taking place along the E-470 corridor - often in the form of master-planned communities. Future development is expected around the 10 planned light rail stations opening along the I-225 Rail Line in 2016. Station areas are envisioned as dense, mixeduse, pedestrian-oriented centers, which support a diverse mix of people and activities. 
Community leaders hope to see the development of a mixture of housing types in station areas. This stems from Aurora’s desire to build housing suitable for high-income earners.

\subsubsection{Arvada}

Arvada is located in the northwest quadrant of the metropolitan region. Neighboring communities include Boulder, Westminster, and Broomfield to the north; Denver to the southeast; and Wheat Ridge and Golden to the south and southwest. Founded as a mining town in the 1860s, Arvada remained largely agricultural until midway through the $20^{\text {th }}$ century. Rapid growth following World War II pushed Arvada to grow from about 3,000 residents in 1950 to 109,800 residents by 2014 (Social Explorer, 2014). Incorporated Arvada covers over 30 square miles in land area.

Olde Town, and the rest of southeast Arvada, are built on a loose grid pattern interspersed with curvilinear streets common to suburban communities. This area will be directly served by RTD's Gold Line, which is scheduled for completion in 2016. The street network in the north and western sections of Arvada are more suburban with a larger numbers of curvilinear streets, loops, and cul-de-sacs.

Arvada adopted comprehensive plans in 1985, 1995 and then again in 2005. Most recently, Arvada adopted a 2014 comprehensive plan, which emphasizes bringing new commercial and industrial development to key locations and shifting the city into becoming a regional economic center. With construction on the Gold Line currently underway, Arvada is expected to play an increasing role as a regional economic center.

\subsubsection{Westminster}

Westminster is centrally located between the cities of Boulder and Denver, in the northwest quadrant of the Denver metropolitan area. The city is bordered by the city and county of Broomfield to the north and west; unincorporated Jefferson County to the west; the cities of Thornton, Northglenn and Federal Heights to the east; unincorporated Adams County to the southeast; and the city of Arvada to the southwest.

Incorporated in 1911, Westminster began as a small community centered on the commercial district in the vicinity of 73rd Avenue and Bradburn Boulevard. In 1950, the population of Westminster was approximately 1,686 residents (Westminster Comprehensive Land Use Plan, 2008). This number grew to 109,296 residents by 2014 (Social Explorer, 2014). During that time, Westminster's land area increased from 4.5 square miles to almost 34 square miles, through the annexation of large tracts of vacant lands to the north and west.

Westminster's development pattern runs the spectrum in terms of both street network and density. Southeast Westminster, the area closest to Denver, has a strong grid network and a higher density of residential development. This area reflects its historic context as the oldest part of the city. Meanwhile, the outer reaches of northern Westminster are characteristic of more recent suburban development -low-density, looping street network - and the advent of branded subdivisions. The northwest rail line will begin operation from Denver's city center to Westminster in 2016, with plans to extend to Boulder and Longmont when future funding becomes available (Northwest Rail Line Factsheet, 2015). 


\subsubsection{Thornton}

Thornton is located due north of Denver and borders the communities of Northglenn, Westminster, Broomfield and Commerce City, to name a few. I-25 runs through parts of Thornton and forms a portion of its western border. Incorporated in 1956, Thornton has historically been a bedroom community with large numbers of residents commuting to downtown Denver for work.

Thornton experienced rapid growth from the mid-1970s to the economic downturn during the mid-2000s. The pace of growth is characterized by the fact that in 1990 the city's population was estimated to be 55,031 (Social Explorer, 1990). By 2014, Thornton had grown to a city of 124,707 residents (Social Explorer, 2014).

Thornton is suburban in nature and dominated by low-density, residential development. The community's urban form consists of curvilinear neighborhood streets framed by built arterial roads built on a grid. The incorporated areas of the city are expansive with a boundary, which is fragmented and jumpy. Large sections of either unincorporated areas or neighboring communities intermingle with much of the Thornton community. The city is well served by freeway access including I-25 and the toll road E-470.

Thornton's first comprehensive plan was adopted in 1974. This plan was updated in 1985 and then again in 1997. Since the turn of the new millennium, Thornton adopted a 2007 comprehensive plan and, more recently, its 2012 comprehensive plan.

In 2018, a 12.5-mile segment of the North Metro Rail Line will begin service to Thornton. The initial build out is scheduled to have six stations, three of which will be located in Thornton. These include the $88^{\text {th }}$ Avenue Station, $104^{\text {th }}$ Avenue Station and $124^{\text {th }}$ Avenue/ Eastlake Station. The $112^{\text {th }}$ Avenue Station is immediately adjacent to the city of Thornton and requires attention from local planning officials as well (North Metro Rail Line Factsheet, 2015). The North Metro Rail Line is located east of the I-25 corridor and runs roughly parallel to the interstate route.

While no timeline has been identified, RTD plans to extend the North Metro Rail Line an additional six miles in the future. When this expansion takes place, two additional stations will be built in Thornton - the $144^{\text {th }}$ Avenue Station and the $162^{\text {nd }}$ Street Station (North Metro Rail Line Factsheet, 2015).

\subsubsection{Centennial}

Centennial is located on the southeast fringe of the Denver metropolitan region. Its neighbors include Aurora, Englewood, Littleton, and Greenwood Village. The area which is now Centennial developed under the jurisdiction of Arapahoe County prior to Centennial's incorporation in 2001. With a population of over 100,000 residents, the establishment of the city of Centennial was the largest single incorporation in Colorado history. Today, Centennial is the seventh-largest city in Colorado.

Centennial's residential development is mostly suburban, with curvilinear streets and cul-de-sacs that contribute to a low level of connectivity. A series of arterial and collector streets are built on a grid pattern, and act as the primary framework for transportation throughout Centennial and to 
the wider metro region. Centennial adopted its first comprehensive plan in 2004. Completed in 2006, RTD’s Southeast Line has one station in Centennial - Dry Creek Station.

\subsubsection{Lone Tree}

Lone Tree is located on the southeast edge of the Denver metropolitan region. Incorporated in 1995, Lone Tree is a young city, which formed in response to growing concerns about development along the C-470 corridor. In 2000, 4,873 residents lived in Lone Tree (City of Lone Tree Comprehensive Plan, 2008). By 2014, the city's population had grown to 12,328 residents (Social Explorer, 2014).

Lone Tree is defined by curvilinear streets built in a suburban style. The city annexed the 3,500acre, master-planned community of RidgeGate in 2000 and the Park Meadows Mall in 2006 (City of Lone Tree Comprehensive Plan, 2008). The Sky Ridge Medical Center was built in Lone Tree in 2003.

In 2006, the Southeast Rail Line arrived in Lone Tree with the dedication of two transit stations Lincoln Station and County Line Station, the latter of which provides access to the Park Meadows Mall and is located just outside the city boundaries. Three additional stations - Sky Ridge, Lone Tree City Center, and RidgeGate Parkway - are scheduled to be built in Lone Tree as a part of the Southeast Rail Extension set for completion in 2019 (Southeast Rail Extension Factsheet, 2015).

Lone Tree's first comprehensive plan was adopted in 1996. This was followed by the 2008 comprehensive plan. The vision statement in Lone Tree's 2008 Comprehensive Plan focuses on creating a vibrant city, with a "full spectrum of community amenities and services, based upon high quality design, environmental sensitivity, sustainability, and careful decision making” (City of Lone Tree Comprehensive Plan, 2008).

\subsubsection{Greenwood Village}

Greenwood Village is located along the southern border of Denver and neighbors Centennial, Englewood, Littleton, and the Cherry Creek Reservoir. Originally settled by gold seekers during the 1860s, Greenwood Village maintained much of its rural character through the first half of the last century. By 1950, the push of development from Denver convinced 138 residents to cast their vote in favor of incorporation, thus creating the Town of Greenwood Village (Greenwood Village Comprehensive Plan, 2012). In 2014, 14,456 people called Greenwood Village home (Social Explorer, 2014).

The Denver Tech Center (DTC), an economic and business center established in 1970, is located along the I-25 corridor in both Greenwood Village and Denver. A major job center for the Denver region, the DTC defines much of eastern Greenwood Village. Western Greenwood Village can be characterized as suburban with large lots and a predominance of large singlefamily homes.

Greenwood Village's current plan was adopted in 2004 and updated in 2012. Completed in 2006, RTD's Southeast Line serves Greenwood Village with two stations - Orchard Road Station and Arapahoe Road Station. Both the Dayton Street (located at I-225) Station and the Belleview 
Avenue Station are located just outside of Greenwood Village. Goals outlined in Greenwood Village's Comprehensive Plan include promoting the village center as a focal point for public transportation and high-density development.

\subsubsection{Lakewood}

Lakewood is located west of Denver in Jefferson County. Originally settled by gold seekers, Lakewood grew into an agricultural community of small dairies and orchards during the late 1800s. Like suburban communities across the United States, Lakewood saw rapid growth during the 1950s. In 1969, Lakewood incorporated with a population of 70,000 residents (Lakewood Comprehensive Plan, 2003).

Lakewood is defined by a number of arterials, which stretch across the city. These key arterials are surrounded by residential neighborhoods with a curvilinear, suburban road network. As a part of this study, Lakewood comprehensive plans from 1987, 1997, 2003, and 2015 were all examined. Lakewood is showing an increased emphasis on TOD in those documents, a trend which corresponds with the completion of the West Rail Line and the advent of light rail service to Lakewood.

\subsubsection{Englewood}

Englewood is located south of Denver in Arapahoe County, and it neighbors Cherry Hills Village, Greenwood Village, Littleton, and Sheridan. Prospectors descended on the area that is now Englewood in 1858 after gold was discovered in the Little Dry Creek. Permanent settlers soon followed, and in 1904 Englewood incorporated as a city (Roadmap Englewood, 2003).

Englewood saw substantial growth in the years following World War II. The majority of the city's housing stock was built during this time. By the 1960s, the majority of Englewood's available land was already in use and the city began annexing unincorporated areas outside the city. Seeking to articulate a more complete vision for Englewood's future, the city adopted its first comprehensive plan in 1969. This document was updated in 1979 and then again in 2003. Currently, Englewood has a draft 2015 comprehensive plan, which is in the review process and is awaiting formal adoption.

Englewood saw 8\% growth during the 1990s, growing from 29,387 residents in 1990 to 31,727 residents in 2000 (Social Explorer, 1990 and 2000). Englewood saw a negative growth rate (4.6\%) from 2000 to 2010 (Social Explorer, 2010). Between 2010 and 2014, Englewood grew by $3.4 \%$ to a population of 31,298 residents (Social Explorer, 2014).

Englewood's street network boasts a consistent grid with short blocks running east to west and longer ones running north to south. Englewood's major auto corridors include US 85 (Santa Fe Drive) which runs north-to-south and US 285 (Hampden Avenue) which runs east to west.

RTD's Southwest Rail Line, which was completed in 1994, runs through Englewood parallel to US 85. There are two stations along the rail line, which provide service to Englewood Englewood Station, which is located inside the city's boundary, and Oxford Station, which is located just over the border in Sheridan. 


\subsection{SALT LAKE CITY REGION}

Planning in the Salt Lake City region has occurred through voluntary and collaborative processes. Planning efforts in the region have occurred through two complimentary processes: regional transportation and land use planning led by the Wasatch Front Regional Council and the Envision Utah process guided by the area's political and business leaders.

\subsection{Wasatch Front Regional Council}

The Wasatch Mountain Range is the western-most chain of the Rocky Mountains. It is situated at the border of three biomes: the Rockies, the Great Basin, and the Colorado Plateau (see Figure 51). To the west is the Great Salt Lake, the remnant of the ancient and much larger Lake Bonneville whose bed now comprises the desolate area known as the Bonneville Salt Flats. This marks the beginning of the Basin \& Range landform that extends across western Utah and Nevada to the Sierra Nevada Mountains west of Reno.

The urbanized area along the west slope of the Wasatch Mountains is comprised of three metropolitan statistical areas, linked together along in a linear north-south development pattern: Ogden-Clearfield, Salt Lake City, and Provo-Orem. With a combined population of nearly 2.4 million (over $80 \%$ of Utah's total), these areas are often referred to collectively as the Wasatch Front. With desert to the west and mountains to the north, south and east, the Wasatch Front is the most significant habitable area for hundreds of miles in all directions. It is - to borrow a phrase attributed to the Mormon pioneer Brigham Young — "the place."

The Wasatch Front is served by two MPOs - the Wasatch Front Regional Council (WFRC) and the Mountainland's Association of Governments (MAG). Covering a substantial majority of the region's geography and population, WFRC is the dominant MPO of the two and takes more policy leadership on transportation and land use issues than MAG. With fewer people, geography and resources, MAG's role is secondary and takes many of its investment and policy cues from its bigger sibling. Hence, we will focus on WFRC in this report.

WFRC is structured after a council of governments model and includes local government representatives from the region's three most populous counties-Salt Lake, Davis, and Weberplus the exurban counties of Tooele, Box Elder, and Morgan.

Nineteen local government representatives from these counties serve as the MPO's decisionmaking body, the WFRC Council. Also on the council are a representative each from the Utah Department of Transportation and the Utah Transit Authority. Six additional, non-voting members serve on the council from the two houses of the Utah Legislature, the Governor's Office of Management and Budget, the Utah League of Cities, the Association of Utah Counties, and Envision Utah (the state's leading planning nonprofit organization).

WFRC began in 1969 as a voluntary collaborative effort of local government leaders in the region's three central counties, with representatives from the exurban counties joining in subsequent years. The Utah governor designated WFRC the MPO for the Salt Lake Urbanized 
Area in 1973 — one of the nation's first designated under the Federal-Aid Highway Act of 1973. The council adopted its first Regional Transportation Plan in 1977.

\section{Figure 5-1: Wasatch Front Region}

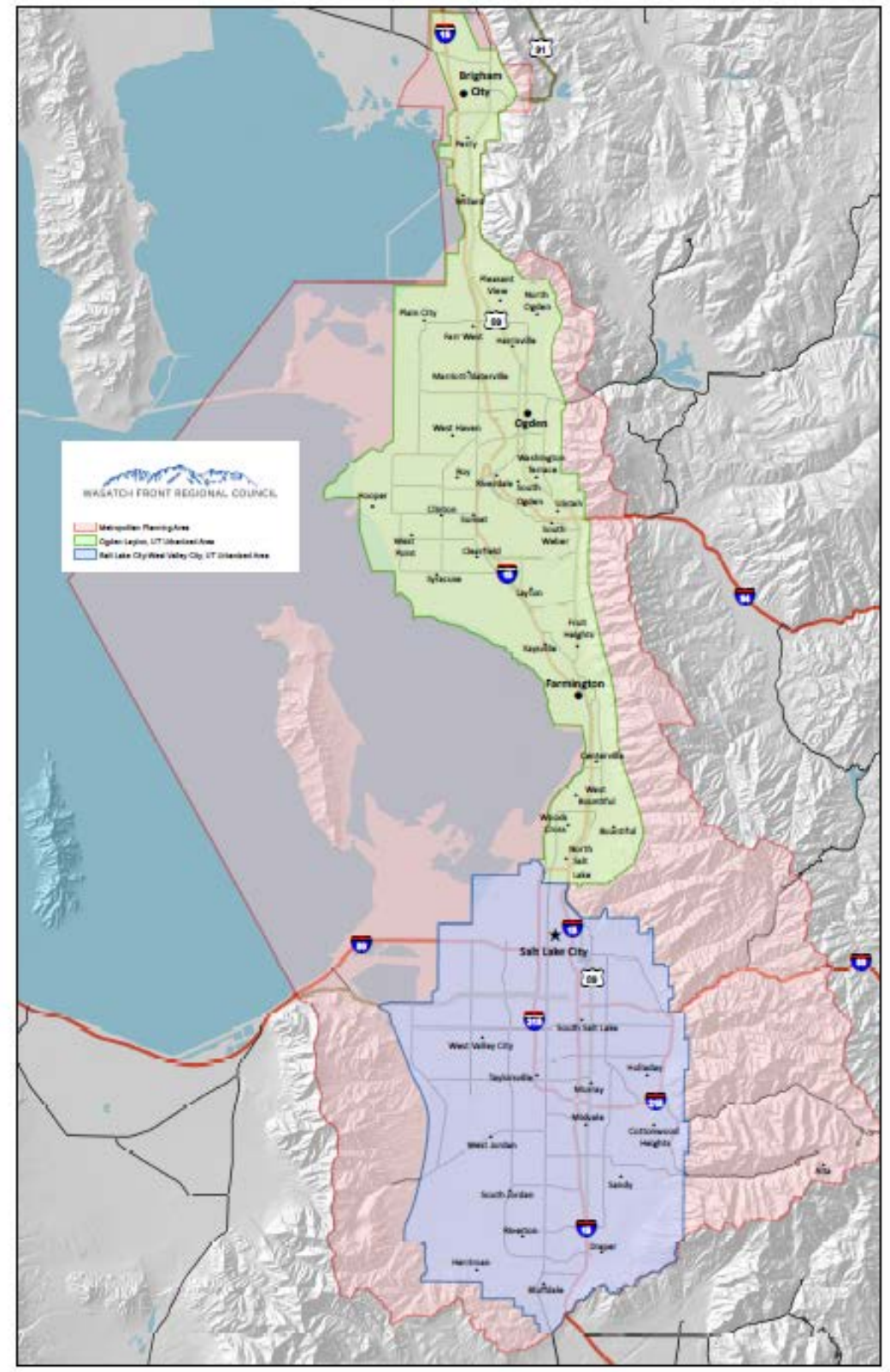

\subsection{Envision Utah}

Envision Utah is a nonprofit planning organization that has deep roots in Utah's recent political history. The name, which is now the official corporate name for the organization, began as the name of a project of the Coalition for Utah's Future (CUF). CUF began, principally, to form a consensus about the use and protection of the state's (mainly federal) wild lands. For decades 
after Congress' passage of the Wilderness Act in 1964, political controversy surrounded the issue of designating wilderness areas in the state. Approximately 740,000 acres of wilderness were designated by Congress in 1984, but there remained between 2 million and 5.7 million additional acres that were worthy of being designated as wilderness, depending on who was counting (Wolf, 1995).

In the mid-1990s, the organization's leadership began to orient toward environmental issues in urban areas. Since the 1950s, Utah's metropolitan along the Wasatch Front had been growing at least double (and during the 1980s, triple) the national average in population, and at least at those levels for jobs (Bartholomew, 2006). Inspired in part by the work being done in Portland, OR, on the LUTRAQ project by 1000 Friends of Oregon (1997), CUF initiated a scenario planning project that would ultimately develop a Quality Growth Strategy to guide development along the Wasatch Front through the year 2020. Although CUF was entirely nongovernmental, it succeeded in accumulating the credibility necessary to gain the attention of significant economic and political leaders - the governor and the owner of the NBA franchise became honorary cochairs - and the organization was able to convince the state legislature to pass "quality growth" legislation (Utah Code sec. 11 38-201 et seq.). Although the act started out with only moderate political authority, which has eroded in the years since its adoption, the intent was to create a local planning mechanism similar to Maryland’s Smart Growth Act (Evensen, 1999).

CUF's success with its initial visioning efforts led to similar projects in southern Utah (Vision Dixie), northern Utah (Envision Cache Valley), southwestern Montana (Envision Missoula), southeastern Idaho (Envision Madison), a series of transit station area plans (e.g., Provo Intermodal Hub), and the mid-Wasatch Mountains (Wasatch Canyons Tomorrow). The organization, now formally renamed Envision Utah, partnered with WFRC and MAG for the Wasatch Choices project, described below. It is now finishing work on Your Utah, Your Future, a statewide scenario planning process setting a vision for the future of the state.

\subsection{Regional Planning In The Salt Lake Region}

\subsubsection{Wasatch Choice Vision For 2040}

WFRC adopted its first version of the Wasatch Choice 2040 Vision in 2005 and adopted the current version in 2010. That version continues to serve as the foundation of the region's Regional Transportation Plan. The Vision is comprised of a map and a set of growth principles, both of which were derived from a scenario planning process (see below) co-sponsored with Envision Utah (a local nonprofit). The principles set "a common sense foundation for actions that can be implemented both locally and regionally to foster high quality of life and help our region compete with other regions” (WFRC n.d.). The growth principles are arranged around the themes of public investment, community resiliency, and collaborative process:

- Provide Public Infrastructure that is Efficient and Adequately Maintained

- Provide Regional Mobility through a Variety of Interconnected Transportation Choices

- Integrate Local Land-Use with Regional Transportation Systems

- Provide Housing for People in all Life Stages and Incomes 
- Ensure Public Health and Safety

- Enhance the Regional Economy

- Promote Regional Collaboration

- Strengthen Sense of Community

- Protect and Enhance the Environment

For each principle, the Vision lists five to 10 objectives designed to provide further definition of the principle and a bridge toward implementation. For example, the principle on land usetransportation integration contains the following objectives:

- Land-use planning and decisions remain a function of local communities.

- Preserve corridors for future infrastructure needs.

- Coordinate regional transportation with centers of development.

- Coordinate transportation decisions with schools and educational centers.

- Make land-use and transportation decisions based on comprehensive understanding of their impact on each other.

\subsubsection{Scenario Planning}

The map portion of the Wasatch Choice Vision is, for many, the most comprehensible and defining element. Built on the earlier work of Envision Utah on the Quality Growth Strategy in the late 1990s, the Vision map is the consensus output from the result of a multiyear-scenario planning process, completed in 2006 and then updated in 2010. This process was influential in setting the development scenarios for the region (see inset below).

\section{Wasatch Choices 2040 Scenario Planning (Bartholomew, 2005)}

The Wasatch Front region of northern Utah, which centers on the urban areas surrounding Salt Lake City, has experienced high rates of population and employment growth for decades. Since 1960, the region has seen at least double the national average in population growth, with comparable increases in employment. These high growth rates are anticipated to continue through the first half of the $21^{\text {st }}$ Century, increasing concerns among regional leaders and citizens about possible impacts on open space, air pollution, water availability, traffic congestion, housing affordability, and fiscal expenditures for public infrastructure and services. Envision Utah, a regional nonprofit organization, sponsored a scenario-based visioning process in the mid-1990s that successfully engaged a wide spectrum of local leaders in articulating a Quality Growth Strategy. While the region's two MPOs-the Wasatch Front Regional Council (WFRC) and the Mountainland Association of Governments (MAG) - participated in this process, they did not incorporate the resulting Strategy into their respective long-range transportation plans. To remedy this disconnection, the MPOs collaborated with Envision Utah to undertake another study-titled Wasatch Choices 2040 - with the specific intention of using a land use-transportation vision generated by the study as the basis for the region's next set of transportation plans. To create that vision, the three agencies-WFRC, MAG, and Envision Utah-instigated a region-wide scenario planning process.

\section{The Nature of the Scenarios}

The scenarios developed for the study were crafted using input from a series of public workshops (described below). Staff analyzed the workshop results using three primary questions: Where in the region did workshop participants prefer for the location of new growth? What type of development did they prefer in those locations (residential, 
commercial, or mixed use)? How dense did they prefer that development to be? A series of "hot spots" emerged from this analysis, indicating some degree of consensus about the appropriate location and intensity of new growth. The assessment also identified four themes that were common among workshop participants: an emphasis on growth centers, a desire for "land recycling," a preference for a variety of housing types, and strong support for pedestrian and bicycle facilities. Utilizing the hot spots and common themes, agency staff crafted four contrasting scenarios.

Scenario A - Business as Usual: Scenario A is based on existing city, county and multi-county plans to guide future growth and transportation.

Scenario B - Transit Station Villages: Scenario B emphasizes urban development in transit station villages. In this scenario, more development centers are clustered near transit stops. The suburbs generally remain at the same densities as found in Scenario A, with some occasional neighborhood villages that mix apartments, condos and neighborhood shopping. Scenario B significantly increases the amount of rail transit by emphasizing rail extensions and bringing light rail and commuter rail to more communities than currently planned.

Scenario C - Interconnected Network of Complete Streets: Rather than encouraging development around transit nodes (like Scenario B), Scenario C intensifies mixed-use development along boulevards that support a complete set of transportation choices: walking, biking, transit and auto use. These boulevards are lined with townhouses, shopping, and employment. New suburban neighborhoods in Scenario C remain largely residential and lower density in character.

Scenario D - Centers of Employment: Scenario D envisions stronger suburban centers of employment in closer proximity to housing areas. Suburban neighborhoods in the scenarios have a greater mix of lot sizes. Scenario $D$ emphasizes construction of new interstates and major roads to serve the region's growing areas.

\section{$\underline{\text { The Evaluation Process }}$}

The scenarios were tested for their impacts on customary transportation indices using the region's travel demand modeling system, which, at the time of this study, contained the following Smart Growth components:
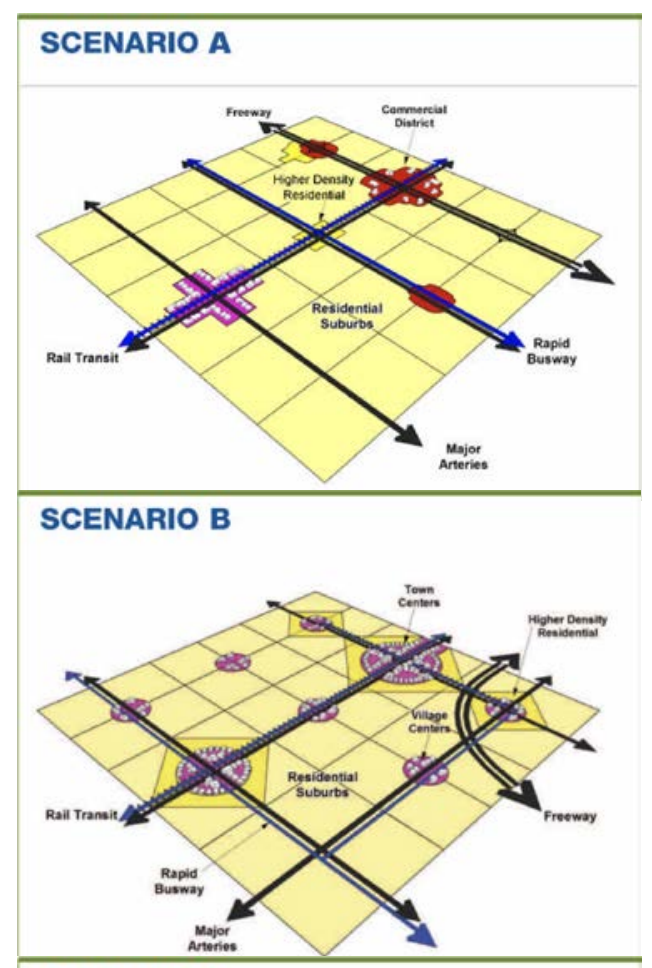

SCENARIO C

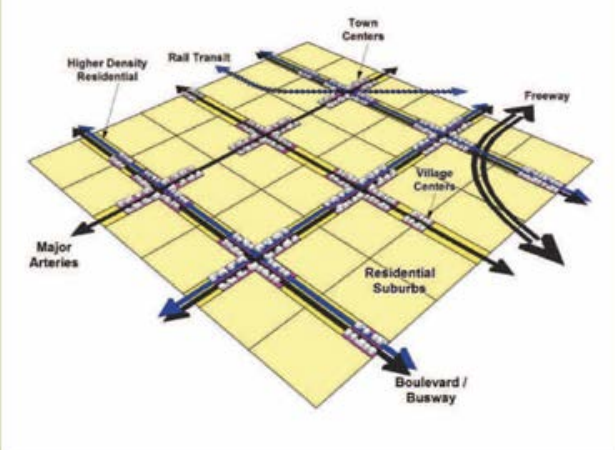

SCENARIO D

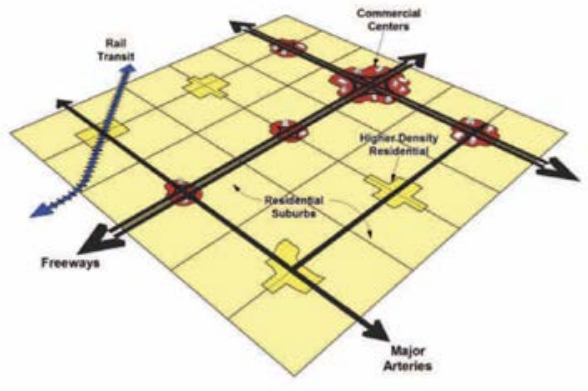




\begin{tabular}{ll}
\hline Smart Growth Model Feature & \\
\hline Daily vehicle trip model & $\mathrm{X}$ \\
Modeling peak period as well as daily travel & $\mathrm{X}$ \\
Simple mode choice model (that separates transit and highway trips) & $\mathrm{X}$ \\
Transit network \& assignment of daily trips to that network & $\mathrm{X}$ \\
Supply \& demand model equilibration & $\mathrm{X}$ \\
Income stratification in distribution and mode choice models & $\mathrm{X}$ \\
Auto ownership modeling sensitive to land use characteristics & $\mathrm{X}$ \\
Travel time feedback loops between model components & $\mathrm{X}$ \\
Non-motorized modes (ped/bike) estimated in mode choice model & $\mathrm{X}$ \\
Modeling multiple modes of access to transit (e.g., ped. vs. park and & $\mathrm{X}$ \\
ride) & \\
\hline
\end{tabular}

In addition, the scenarios were also evaluated for their impacts on water consumption, land consumption, proximity to transit, and public infrastructure costs.

\section{Evaluation Results}

The evaluation of the scenarios demonstrated several key themes. First, mixed-use development can be effective in reducing travel. Scenario C mixed more homes with destinations (accounting for more than $20 \%$ of future growth); this significantly reduced average driving distances, which in turn reduced congestion and emissions of air pollutants. Second, locating growth near transit—as in Scenario B-encourages people to ride transit. Third, people will walk and bicycle if the trip is short and the street design is right. Fourth, transportation choices help determine where growth will occur and how much land will be developed. Fifth, interconnected streets help to keep short trips off of highways and regional arterials. Last, relatively small changes in development locations and densities, if well chosen and implemented, can have surprisingly significant impacts on travel patterns and transportation consumption; for example, Scenario $\mathrm{C}$ contains only $6 \%$ more multi-family housing units than Scenario A, but has $10 \%$ less congestion and $3 \%$ fewer vehicle miles travelled.

\begin{tabular}{lllll}
\hline & Scenario A & Scenario B & Scenario C & Scenario D \\
\hline Lane miles of highways, ramps, arterials \& & 8,757 & 8,147 & 9,099 & 9,067 \\
collectors & 175,349 & 191,849 & 181,849 & 181,349 \\
Annual transit revenue hours* & 854 & 798 & 845 & 905 \\
Total developed land (sq. mi.) & $0.6 \%$ & $13.5 \%$ & $17.6 \%$ & $5.8 \%$ \\
\% dwellings in mixed use areas & $24 \%$ & $27 \%$ & $26 \%$ & $23 \%$ \\
$\%$ growth through redevelopment & $22 \%$ & $46 \%$ & $40 \%$ & $9 \%$ \\
\% dwellings walking distance to transit & 81.2 & 79 & 80.9 & 85.4 \\
Average daily VMT (millions) & 450,000 & 530,000 & 350,000 & 400,000 \\
Average daily hours of delay & 193,865 & 111,363 & 162,765 & 240,281 \\
Acre feet of water consumed per year & $\$ 31.5$ & $\$ 23.2$ & $\$ 18.6$ & $\$ 37.4$ \\
\hline Public infrastructure costs (billions) & & & & \\
\hline
\end{tabular}

* estimated

\section{Elected Official Participation/Public Involvement}

The Wasatch Choices process employed multiple techniques to engage citizens and local leaders. The study was directed by a steering committee composed of mayors, city council members, county commissioners, environmental advocates, representatives of other regional agencies, and business executives. Members of the steering committee 
and agency staff sponsored 13 public workshops around the region that attracted more than 1000 citizens. Workshop participants engaged in the "growth chip game," allocating expected future growth on large scale maps using chips that represent more than two dozen different development archetypes and quantities. They also used different colored tapes to represent their preferred transportation improvements. A total of 119 maps were created through this process. Workshop participants also completed surveys about key environmental, growth, and transportation issues in the region. These workshop results provided the structure for creating the four scenarios outlined above. Once the impacts of the scenarios had been assessed, the agencies hosted an additional 13 public workshops to receive reaction and input on the analysis.

\section{$\underline{\text { Resulting Actions }}$}

From the feedback received in the final set of workshops, the staffs of the three agencies crafted a preferred Vision Scenario, which borrowed elements primarily from scenarios B and C. The workshops also provided the basis for a draft set of regional Growth Principles and Objectives that were further refined by a new Regional Growth Committee created by the two MPOs. The final set of principles and objectives were formally adopted by the boards of the two MPOs and, eventually, by all but four of the local governments in the region. The MPOs are currently working with elected officials, stakeholders, and the public to further refine the Vision Scenario in preparation for new updates to the regional transportation plans, which are expected to be completed late in 2010.

\subsubsection{Centers}

The most prominent feature of the Vision Map are the centers that are scattered across the region. These centers, comprising only a small percentage of the region's land mass, are slated to receive a substantial majority of future growth. Interviews with WFRC staff indicate that the centers-based approach appealed to a number of constituencies: business interests favored it because it promised the possibility of higher-intensity growth; local officials liked the higher tax revenue that might come from that growth; neighborhood activists liked it (mostly) because it meant that most established neighborhoods would be shielded from development pressures; and planners and environmentalists liked it because it facilitated the creation of more pedestrian- and transit-oriented development.

According to the current WFRC Regional Transportation Plan (WFRC, 2015, 16), the centers can:

- Help ensure all people have a selection of homes to meet their needs;

- Reduce the time, distance and money it takes for people to reach many of their destinations;

- Enable people to reach more of those destinations by foot, bike and transit in addition to car;

- Help businesses reach more consumers and employees to have a greater selection of jobs;

- Help improve the air quality;

- Create walkable communities;

- Reduce growth pressure on the "Wasatch Back"; and

- Reduce demand for scarce water.

The Vision's taxonomy of centers includes (WFRC, 2015, 15):

- Metropolitan Center: The region’s primary business district - downtown Salt Lake City; 
- Urban Center: Urban centers are the focus of commerce and local government services benefiting a market area of a few hundred thousand people;

- Town Center: Town centers provide localized services to tens of thousands of people within a two- to three-mile radius;

- Station Community: Station communities are geographically small, high-intensity centers surrounding high-capacity transit stations;

- Main-street Community: Main streets are linear town centers, with a traditional commercial identity, but on a community scale;

- Boulevard Community: Boulevard communities are linear centers coupled with a transit route, but not necessarily associated with commercial activity.

According to WFRC staff, the selection/designation of centers was the result of both technical information and political negotiation. The technical analyses included assessments of population/market catchment areas and a series of incremental interactive land use-transportation simulations using the agency's version of UrbanSim (Waddell, 2002). Together, the Wasatch Choices map and principles served as the vision for the 2015 Regional Transportation Plan and informed the plan's travel demand model forecasts and resulting need assessments and project selection lists.

\subsection{Case Study Cities}

To examine how the regional plans and policies related to metropolitan centers have translated to the local level, we selected seven cities in Salt Lake City Region for detailed analysis. As noted in the methods section, the goal in selecting these cities was to choose cases that:

- Represented a cross section of jurisdictions

- Had prepared several generations of plans so we could assess plan changes over time

- Contained designated centers in the regional plan

In the sections below, we summarize some of the key characteristics of each case study city, including its history related to planning and expansion of the region’s light rail system.

Figure 5-2: Demographic Summary (Salt Lake City Region)

\begin{tabular}{|l|l|l|l|l|l|l|}
\hline City & $\begin{array}{l}\text { Per Capita } \\
\text { Income }\end{array}$ & $\begin{array}{l}\text { Median Home } \\
\text { Value (Owner } \\
\text { Occupied } \\
\text { units) }\end{array}$ & $\begin{array}{l}\text { Below } \\
\text { Poverty Line } \\
\text { (Families) }\end{array}$ & White Alone & $\begin{array}{l}\text { Black or } \\
\text { African } \\
\text { American } \\
\text { Alone }\end{array}$ & $\begin{array}{l}\text { Hispanic or } \\
\text { Latino }\end{array}$ \\
\hline Pleasant View & $\$ 33,380$ & $\$ 273,500$ & $4.0 \%$ & $96.6 \%$ & $0.0 \%$ & $6.5 \%$ \\
\hline Clearfield & $\$ 19,043$ & $\$ 152,600$ & $12.1 \%$ & $87.3 \%$ & $3.4 \%$ & $16.1 \%$ \\
\hline Murray & $\$ 29,013$ & $\$ 225,300$ & $9.3 \%$ & $89.8 \%$ & $2.0 \%$ & $10.8 \%$ \\
\hline Sandy & $\$ 31,552$ & $\$ 272,300$ & $6.0 \%$ & $90.7 \%$ & $0.6 \%$ & $8.2 \%$ \\
\hline South Jordan & $\$ 29,964$ & $\$ 324,100$ & $2.9 \%$ & $92.2 \%$ & $0.4 \%$ & $5.1 \%$ \\
\hline Lehi & $\$ 22,510$ & $\$ 242,900$ & $5.6 \%$ & $93.8 \%$ & $0.2 \%$ & $7.8 \%$ \\
\hline Salt Lake City & $\$ 28,428$ & $\$ 235,200$ & $14.5 \%$ & $74.6 \%$ & $2.9 \%$ & $20.9 \%$ \\
\hline
\end{tabular}


Figure 5-3: Case Study Community Profile (Salt Lake City Region)

\begin{tabular}{|c|c|c|c|c|c|}
\hline City & $\begin{array}{l}\text { Population } \\
\text { (DATE) }\end{array}$ & Growth Rate by Decade & Location & Transit & General Plan Updates \\
\hline $\begin{array}{l}\text { Pleasant } \\
\text { View }\end{array}$ & $\begin{array}{l}8,948 \\
(2014)\end{array}$ & $\begin{array}{lll}1990 & 3,603 & \\
2000 & 5,632 & 56.3 \% \\
2010 & 7,979 & 41.7 \% \\
2014 & 8,948 & 12.1 \%\end{array}$ & $\begin{array}{l}\text { Newer standalone } \\
\text { rural }\end{array}$ & $\begin{array}{l}\text { FrontRunner (1 stop } \\
\text { with limited access in } \\
\text { the morning and } \\
\text { evening). Opened Sept. } \\
\text { 2008. Suspended } \\
\text { service from Sept. } 2011 \\
\text { - Dec. } 2012 \text {. Reopened } \\
\text { Dec. } 2012 \text {. }\end{array}$ & $\begin{array}{l}\text { 2009, updating plan this } \\
\text { year (2014). }\end{array}$ \\
\hline Clearfield & $\begin{array}{l}30,484 \\
(2014)\end{array}$ & 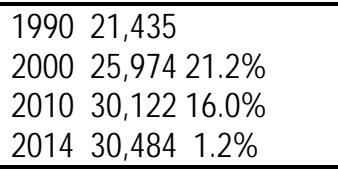 & $\begin{array}{l}\text { Newer outer-ring } \\
\text { suburban }\end{array}$ & $\begin{array}{l}\text { FrontRunner (1 stop). } \\
2 \text { local bus routes. } \\
\text { FrontRunner began } \\
\text { service in April } 2008 .\end{array}$ & $\begin{array}{l}\text { 2010. Zoning map } \\
\text { updated in } 2012 \text {. Not } \\
\text { currently in the process of } \\
\text { updating General Plan. }\end{array}$ \\
\hline Murray & $\begin{array}{l}48,822 \\
(2014)\end{array}$ & 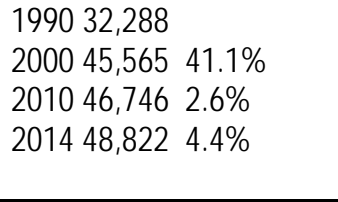 & $\begin{array}{l}\text { Older inner-ring } \\
\text { urban }\end{array}$ & $\begin{array}{l}\text { FrontRunner (1 stop), } \\
\text { TRAX ( } 3 \text { stops) } \\
\text { Bus routes. } \\
\text { FrontRunner began } \\
\text { service Dec. } 2012 .\end{array}$ & $\begin{array}{l}\text { 2003, will update plan } \\
\text { over next few months } \\
\text { (March 2016). }\end{array}$ \\
\hline Sandy & $\begin{array}{l}91,148 \\
(2014)\end{array}$ & $\begin{array}{ll}199075,058 & \\
200088,418 & 17.8 \% \\
201087,418 & -1.1 \% \\
201491,148 & 4.2 \% \\
\end{array}$ & $\begin{array}{l}\text { Older outer-ring } \\
\text { urban }\end{array}$ & $\begin{array}{l}\text { TRAX (4 stops), } \\
\text { Bus routes. }\end{array}$ & $\begin{array}{l}2003, \text { no } \\
\text { revisions/updates } \\
\text { planned. }\end{array}$ \\
\hline $\begin{array}{l}\text { South } \\
\text { Jordan }\end{array}$ & $\begin{array}{l}62,781 \\
(2014)\end{array}$ & $\begin{array}{l}199012,220 \\
200029,437140.9 \% \\
201050,41871.3 \% \\
201462,781 \quad 24.5 \%\end{array}$ & $\begin{array}{l}\text { Newer outer-ring } \\
\text { suburban }\end{array}$ & $\begin{array}{l}\text { FrontRunner (1 stop), } \\
\text { TRAX (2 stops), } \\
\text { Bus routes. } \\
\text { FrontRunner began } \\
\text { service Dec. } 2012 \text {. }\end{array}$ & $\begin{array}{l}\text { 2010, no } \\
\text { revisions/updates } \\
\text { planned. }\end{array}$ \\
\hline Lehi & $\begin{array}{l}56,275 \\
(2014)\end{array}$ & $\begin{array}{l}19908,475 \\
200019,028124.5 \% \\
201047,407149.1 \% \\
201456,27518.7 \%\end{array}$ & $\begin{array}{l}\text { Older outer-ring } \\
\text { suburban }\end{array}$ & $\begin{array}{l}\text { FrontRunner (1 stop), } \\
\text { Bus routes. } \\
\text { FrontRunner began } \\
\text { service Dec. } 2012 .\end{array}$ & $\begin{array}{l}2011, \text { no } \\
\text { revisions/updates } \\
\text { planned. Previous update } \\
\text { was in } 2001 .\end{array}$ \\
\hline $\begin{array}{l}\text { Salt Lake } \\
\text { City }\end{array}$ & $\begin{array}{c}190,884 \\
(2014)\end{array}$ & $\begin{array}{l}1990159,936 \\
2000181,74313.6 \% \\
2010186,4402.6 \% \\
2014190,8842.4 \%\end{array}$ & Central City & $\begin{array}{l}\text { FrontRunner ( } 2 \text { stops), } \\
\text { Extensive bus routes. } \\
\text { TRAX (33 stops). } \\
\text { FrontRunner began } \\
\text { service April } 2008 .\end{array}$ & $\begin{array}{l}\text { "Plan Salt Lake" adopted } \\
2015 . \text { Neighborhood plans } \\
\text { vary in adoption year by } \\
\text { neighborhood. }\end{array}$ \\
\hline
\end{tabular}




\subsubsection{Pleasant View}

Pleasant View is a residential city just north of Ogden. Pleasant View was first settled in 1850, and was incorporated as a town in 1945. The city was originally composed of mostly farmland and rural developments until the mid-20 ${ }^{\text {th }}$ century. As of 2014, approximately half of the land in the city is occupied by residential properties. Undeveloped open space accounts for a quarter of the land, and the remaining quarter is made up of agriculture, roads, retail, and industry. The Pleasant View Planning Commission has expressed a desire for the city to continue as a lowerdensity residential suburb.

Pleasant View currently has a FrontRunner station with limited service. The FrontRunner makes two trips from Pleasant View in the morning and returns twice in the evening, leaving little room for travel other than for a structured southbound work commute. Pleasant View plans to work with the UTA to expand service, though when that will happen is still uncertain. Pleasant View is currently updating its General Plan, which should be completed in summer or fall of 2016. The new general plan anticipates that the city will approximately double in population and housing units between 2010 and 2040 (to 8,340 housing units and 16,258 people, respectively). Pleasant View's General Plan anticipates that the population will reach its maximum "build out" threshold by 2040. As it currently stands, Pleasant View more than doubled in population from 1990 to 2010.

\subsubsection{Clearfield}

Clearfield was one of the final communities to be settled in Davis County in the late $19^{\text {th }}$ century, and was incorporated as a city in March of 1946. Clearfield lies approximately 30 miles to the north of Salt Lake City and borders Hill Air Force Base (HAFB). HAFB is the sixth-largest employer in the state and currently employs nearly 15,000 people (Utah Department of Workforce Services, 2014). Additionally, HAFB's direct operations divvy out a payroll of nearly \$1 billion each year (Utah Governor's Office of Economic Development, 2015). Since it was incorporated, the city has seen steady, continued growth, and now claims over 30,000 residents.

Clearfield has one FrontRunner station, which opened in 2008. Clearfield's FrontRunner station has 561 park and ride spaces (Utah Transit Authority, 2015). Clearfield has two local bus routes and does not currently have plans for any TRAX stations. Clearfield is primarily a suburban city, and lies on the outer ring of urban development centered around Salt Lake City. The city updated its General Plan in 2012, and has no immediate plans to update it again.

\subsubsection{Murray}

Murray is home to the Intermountain Medical Center, which is the largest employer in the city. The city of Murray has existed since 1903, when it was incorporated. It is located about eight miles south of downtown Salt Lake City, and is a continuation of the inner ring of urban development surrounding Salt Lake City. Murray was once known for its high presence of heavy industry, but has largely shifted from heavy industry to commercial retail. Murray has a strong bus system in place, as well as three TRAX stations (Red and Blue lines). FrontRunner has one stop at Murray Central Station, which is a central location for FrontRunner, TRAX, and buses. Two major roads run through Murray_eight lanes on I-215 and 10 lanes on I-15. 
Murray is currently working with CRSA (a private architectural firm) to update its General Plan, and expects to release it by the fall of 2016.

\subsubsection{South Jordan}

South Jordan is located approximately 17 miles south of Salt Lake City, and was incorporated in November, 1935. South Jordan is a rapidly developing residential community, with large amounts of retail and employment centers having emerged over the past decade or so. South Jordan revised its General Plan in 2010 and has no current plans to update it again.

Daybreak, a new urbanist community that began in 2004, may help to double the population of South Jordan over the next 25 years. South Jordan anticipates a 90\% build out rate and 95,000 residents by 2030.

Two TRAX stations are located in Daybreak. FrontRunner stops along the east side of South Jordan. Additional residential development is being planned around the FrontRunner stop. Two large highways will eventually service South Jordan. Bangerter highway is currently in use and has six lanes, and Mountain View Corridor is expected to have 10 lanes once fully built out. Currently, the Mountain View Corridor has two lanes in each direction that run through Daybreak and the west side of South Jordan. Full build out on the road is expected by 2030 .

\subsubsection{Lehi}

Lehi is a rapidly growing city that lies approximately halfway between Salt Lake City and Provo. Although Lehi was incorporated in 1852, it did not surpass 10,000 residents until the 2000 Census. As of 2014, the city has approximately 56,000 residents, making it one of the fastest growing cities of its size in the nation.

Lehi has attracted a plethora of tech companies to the area, the largest of which is an Adobe office that employs over 1,100 people. Other firms to come into the area include Oracle, IM Flash Technologies, Intel Corporation, Microsoft and Workfront, to name a few. Lehi last updated its General Plan in 2011, and does not have any pending plans to revise it. Lehi is expected to grow faster than any city its size (in Utah) over the next three decades. Lehi projects its population to be around 147,000 by 2040 , which would be $100 \%$ built out. In 1990 , Lehi had just over 8,000 residents.

Lehi has identified and set aside two areas as TOD hubs that run parallel to I-15. Lehi wants to work with UTA to bring light rail into the city. Currently, Lehi has one FrontRunner stop and several bus routes.

\subsubsection{Sandy}

Sandy is one of the older cities in the study, as it was founded in 1871 and incorporated as a city in 1893. Sandy is notable in the region due to being the home of Real Salt Lake (Major League Soccer) and the Utah Jazz (NBA). As of 2010, Sandy was the sixth-largest city in the state (U.S. Census, 2010). Sandy is also in close proximity to Little Cottonwood Canyon and several prominent ski resorts. 
Sandy runs on the traditional "grid system" put into place in the early years of Utah's settlement by non-indigenous peoples. Sandy has no FrontRunner stations but does have four TRAX stations, all of which are serviced by the Blue Line. The Blue Line connects Sandy to Draper on the south to downtown Salt Lake City and its Central Station on the north. Sandy's TRAX stations opened between 1999 and 2013. From Historic Sandy Station and Sandy Civic Center Station's opening in 1999, the city saw two additional TRAX stations opened in 2006 and 2013, respectively (Utah Transit Authority, 2015).

Sandy is an older outer-ring suburb of Salt Lake City. The city revised its General Plan back in 2003, but has not been involved with an update since that time.

\subsubsection{Salt Lake City}

Salt Lake City is the capital city of Utah, and the state's largest city. Salt Lake City was founded in 1847 by Brigham Young, the president of the LDS faith at the time. Salt Lake City hosted the 2002 Winter Olympics, and is located within 50 miles of over a half-dozen world famous ski resorts. The city is also home to other major cultural, historical, and artistic places and venues, as well as the second-largest state university in terms of enrollment, the University of Utah.

Salt Lake City is home to the first light rail line in the state (the Blue Line, which runs from downtown Salt Lake City to Sandy), and also houses stations for the other two light rail lines and the commuter train, the FrontRunner. Salt Lake City adopted a citywide master plan in 2015, and also has master plans for several neighborhoods within the city. 



\subsection{FINDINGS: CHANGES IN PLANNING}

This chapter reviews the findings related to changes in regional and local planning. We review changes in regional plans and then compare the trends among changes in local plans in both regions. Based on our plan analysis and planner interviews, we review the major driving forces behind these plan changes.

\subsection{Evolution of Regional Plans: Denver}

First adopted in 1997, the Denver Regional Council of Government's (DRCOG) Metro Vision documents have promoted the idea of urban or metropolitan centers and voluntary management of regional growth. The Metro Vision plan grew out of a multiyear planning process that originated in its regional transportation planning process. While the definition of centers has evolved slightly over time, the basic concept is to steer future growth into centers of highdensity, mixed-use development. DRCOG's scenario planning has found that this would allow the region to consume less land, increase access to transit, and reduce the number of vehicle trips.

Metro Vision 2020 defines centers as "a range of activity centers in the region that serve as transit destinations; support a range of retail, civic, cultural, employment and residential uses; contain higher densities than the regional average; and encourage pedestrian-oriented travel” (DRCOG, 1997).

In Metro Vision 2020, the identification and implementation of various types of urban centers was referred to as “a continuing effort.” Metro Vision 2030, adopted in 2005, includes a short list of urban center policies, which cover location, future regional growth, infrastructure investment, and design of urban centers. These policies are broad in scope but their inclusion marks DRCOG's growing emphasis on the implementation of centers policy. The plan also includes specific center implementation actions. These actions call for DRCOG to work with local governments to identify future centers, monitor the performance of centers, and coordinate transportation planning and funding to support their development.

Metro Vision 2030 defines centers as "areas of concentrated development that are mixed-use, pedestrian friendly, and accessible to a wide variety of transportation modes." It goes on to note that urban centers "will be served by transit, either rapid transit or bus, and also will support transit by providing riders and pedestrian-oriented environments” (DRCOG, 2005).

Metro Vision 2035, adopted in 2011, marked a continued shift towards a direct focus on centers' development. The biggest evolution to emerge in Metro Vision 2035 was the goal that "urban centers will accommodate 50 percent of new housing and 75 percent of new employment between 2005 and 2035.” The specificity of this language is clear and measurable, something that was absent in both of the previous Metro Vision plans. Metro Vision 2035 also includes a list of center policies with a higher level of specificity. 
In addition to the regional plans, DRCOG has supported centers through incentives. As noted above, transportation projects serving designated centers receive additional points in the competitive Transportation Improvement Program (TIP) funding process. Furthermore, DRCOG has also provided grants for planning studies - though these have mostly been allocated to station area planning efforts. Transportation funding incentives seek to encourage local governments to designate centers. In practice, the identification and designation of centers has been a negotiated process between local governments and DRCOG. This has created vague criteria for what constitutes a center, how the boundaries of centers are defined, and whether centers will ever achieve their transit and development goals.

\subsection{Evolution of Regional Plans-Salt Lake City}

Regional planning in the Salt Lake metro area originated in the work conducted by Envision Utah in the mid-1990s. As outlined above, Envision Utah undertook a regional visioning exercise that was inspired to a considerable degree by 1000 Friends of Oregon's LUTRAQ project and Portland Metro’s Region 2040 project. The primary similarity with those two exemplars was the use of scenario creation and analysis to foster dialogue about policy development on land use and transportation investments. Different from those two examples, however, was the use of values research as a primary tool to prioritize scenario elements and frame issues for public discussion. This research, conducted before the public meetings to develop the project's scenarios, used surveys and focus groups to identify characteristics about the region that respondents valued and issues they saw as threatening the region's future livability. Using a "laddering” technique borrowed from market research disciplines, the research team connected these concrete characteristics about regional livability to higher-order values (Wirthlin Worldwide,1997). Envision Utah used these "value ladders" to frame issues and communicate themes for the subsequent scenario exercise.

To build the scenarios, Envision Utah employed the "chip game” of having public meeting participants allocate expected future growth increments on a large-scale map of the region using chips representing varying development amounts and types. Participants also used colored tape on the maps to indicate desired transportation improvements. Over the course of dozens of workshops, Envision Utah staff were able to coalesce results into four divergent scenarios for regional growth. The scenarios included a "business as usual" scenario, a "follow current plans" scenario, and then two centers-based scenarios at two levels of density/intensity (Bartholomew, 2005).

A public consensus favoring the two centers scenarios (about equally) led to the creation of a Quality Growth Strategy containing features of both scenarios (Envision Utah, 2000). This work inspired the Utah governor and members of the state legislature to create a Quality Growth Commission to help implement policy recommendations consistent with the Strategy (Utah Code 11-38-2). Little changed with respect to local government policy in response to these initiatives, however, and the authority and effectiveness of the Quality Growth Commission has been questioned (Evensen, 1999). 
Figure 6-1: Regional Planning Timeline

\begin{tabular}{|c|c|c|}
\hline Year & Denver Region & Salt Lake City Region \\
\hline 1992 & $\begin{array}{l}\text { DRCOG Board adopts vision statement for Metro } \\
\text { Vision }\end{array}$ & \\
\hline 1994 & $\begin{array}{l}\text { Central Corridor (now D Line) opens (Auraria } \\
\text { Campus-Denver-30th) }\end{array}$ & \\
\hline 1995 & & $\begin{array}{l}\text { Growth Summit conference sponsored by } \\
\text { legislative leadership and the Governor }\end{array}$ \\
\hline 1997 & $\begin{array}{l}\text { March: DRCOG Board adopts Metro Vision } 2020 \\
\text { November: Guide to Ride vote fails to pass }\end{array}$ & $\begin{array}{l}\text { Working with the Governor's office, Envision Utah } \\
\text { creates Baseline Scenario and sponsors values } \\
\text { research }\end{array}$ \\
\hline 1998 & & $\begin{array}{l}\text { Envision Utah creates and analyzes alternative } \\
\text { scenarios }\end{array}$ \\
\hline 1999 & $\begin{array}{l}\text { Voters approve two bond measures to fund } \\
\text { construction of the Southeast corridor project (later } \\
\text { named Transportation Expansion Project or T-REX }\end{array}$ & $\begin{array}{l}\text { Envision Utah finalizes Quality Growth Strategy; } \\
\text { legislature creates the Quality Growth Commission } \\
\text { TRAX Blue Line Opens (Salt Lake City - Draper) }\end{array}$ \\
\hline 2000 & $\begin{array}{l}\text { July: Southwest extension opens (Denver- } \\
\text { Littleton) } \\
\text { August: } 25 \text { municipalities sign Mile High Compact }\end{array}$ & \\
\hline 2001 & $\begin{array}{l}\text { Construction begins on Southeast corridor (T-REX } \\
\text { project) }\end{array}$ & $\begin{array}{l}\text { TRAX Red Line Opens (U. Utah-Salt Lake City- } \\
\text { Daybreak) }\end{array}$ \\
\hline 2002 & $\begin{array}{l}\text { Central Platte extension opens ( } 10^{\text {th }} / \text { Osage to } \\
\text { Union Station) }\end{array}$ & \\
\hline 2004 & Voters approve of FasTracks program & \\
\hline 2005 & DRCOG Board adopts Metro Vision 2030 & $\begin{array}{l}\text { Envision Utah \& MPOs develop Wasatch Choice } \\
\text { Growth Principles and Objectives }\end{array}$ \\
\hline 2006 & $\begin{array}{l}\text { Southeast corridor opens. T-REX project } \\
\text { completed being ahead of schedule and under } \\
\text { budget }\end{array}$ & $\begin{array}{l}\text { Frontrunner commuter rail opens (Ogden-Salt } \\
\text { Lake City-Provo) }\end{array}$ \\
\hline 2007 & & Envision Utah sponsors additional values research \\
\hline 2009 & & $\begin{array}{l}\text { Envision Utah \& MPOs develop and analyze } \\
\text { alternative scenarios }\end{array}$ \\
\hline 2010 & & $\begin{array}{l}\text { MPOs adopt Wasatch Choice Vision Map and } \\
\text { Regional Growth Principles }\end{array}$ \\
\hline 2011 & DRCOG Board adopts Metro Vision 2035 updates & TRAX Green Line Opens (Airport-West Valley) \\
\hline 2013 & West Line Opens (Denver-Golden) & S Line Streetcar opens (Central Point-Fairmount) \\
\hline 2016 & $\begin{array}{l}\text { Gold Line Opens (Denver-Arvada-Wheat Ridge) } \\
\text { East Line Opens (Denver-Aurora-Airport) } \\
\text { R Line Opens (Denver-Aurora-Lone Tree) } \\
\text { US } 36 \text { Express Bus Line (Denver-Boulder) }\end{array}$ & \\
\hline 2018 & N Line commuter rail (Denver-Thornton) & \\
\hline
\end{tabular}

The Quality Growth Strategy, however, became the basis for the 2010 update to the region's Regional Transportation Plans. The first step in the process was the MPO's adoption of a set of Growth Principles and Objectives (Envision Utah, 2005). This led to additional values research. The Utah Values \& Future Growth report (Harris Interactive, 2007) repeated and refined the laddering research conducted a decade earlier, showing similar associations between community attributes and personal values, but a greater level of concern about the possible negative impacts 
of future growth. The final step was the creation of the Wasatch Choice Vision Map, which was then incorporated as part of the region's RTPs in 2010.

The resulting Wasatch Choices 2040 document is a broad vision that provides a set of regional principles and a set of implementation strategies available to local governments in the region. The principles listed in the document are vague and the objectives largely unmeasurable. For example, one relevant principle is to "Integrate Local Land-Use with Regional Transportation Systems” (Wasatch Choice, 2040, 16) and the objectives under this principle include:

- Land use planning and decisions remain a function of local communities.

- Preserve corridors for future infrastructure needs.

- Coordinate regional transportation with centers of development.

- Coordinate transportation decisions with schools and educational centers.

- Make land use and transportation decisions based on comprehensive understanding of their impact on each other.

The centers listed in the Wasatch Choice 2040 document are not named or defined, but simply listed on a regional map as "Mixed-Use Centers."

\subsection{Local Plan Changes: Denver and Salt Lake City Regions}

In our review of local government planning in the Denver and Salt Lake City regions, we analyzed local comprehensive plans over time to assess two specific issues: (1) The extent to which they referenced regional visioning, regional planning and the regional planning organizations in their plans; and (2) The extent to which they incorporated the concept of centers into their plans and how they defined and interpreted those centers.

In Denver communities, we examined three generations of plans: before 1996, between 1997 and 2004, and after 2005. The first time period was selected based on the DRCOG Board's adoption of Metro Vision 2020 in 1997. The second time period (those prepared between 1997 and 2004) was chosen based on the 2005 adoption of Metro Vision 2030. The third time period (2005present) allowed the research team to review local plans adopted after the completion of Metro Vision 2030.

In the Salt Lake City region, we analyzed plans over three time periods: before 1998, between 1999 and 2009, and after 2010. The first time period (before 1998) was chosen because the first Envision Utah finalized its Quality Growth Strategy. The second time period (1999-2009) was chosen because the Wasatch Choice for 2040 (originally created in 2005) was officially adopted in 2010. The last time period (2010-present) was chosen to analyze developments and changes within local plans since the official adoption of the regional plan in 2010.

\subsubsection{Regional Vision Adoption in Local Plans}

With regards to referencing of the regional vision, plans and planning organizations, we found that these concepts have appeared sparingly in local comprehensive plans in both the Denver and Salt Lake City regions. 


\subsubsection{Denver}

In the Denver region, many of the first generation of plans were prepared prior to or during the development of Metro Vision 2020, and do not make any reference to Metro Vision or the Mile High Compact. DRCOG is referenced in many of these documents, but in most cases only in general terms. Second-generation plans see more references to Metro Vision and DRCOG and an increase in collaboration on centers' implementation; however, in many cases, findings are mixed. For example, second-generation comprehensive plans for Thornton and Westminster note that they are consistent with DRCOG's Metro Vision Plan, but do not refer to specific policies or actions at the local level. Generally, third-generation plans did not show a significant increase in discussion of Metro Vision as compared to second-generation plans. Key exceptions include Aurora (2009 Comprehensive Plan) and Arvada (2005 Comprehensive Plan), which place significant emphasis on the consistency of local plans and policies with regional policies.

While findings on Metro Vision and DRCOG were mixed, discussion of the Regional Transportation District (RTD) and FasTracks program were increasingly included in local plans. Most notable is the extensive discussion of RTD and FasTracks in third-generation plans including Aurora, Lakewood, Lone Tree, Arvada, and Westminster. This trend is clearly illustrated in Arvada where the FasTracks program is first discussed in the 2005 Comprehensive Plan without any specific actions identified. The Aurora 2014 Comprehensive Plan outlines specific policies related to FasTracks construction including:

- $\quad$ Policy T-1.4: Gold Line and Other FasTracks Integration "The City will actively participate in the planning of the RTD Gold Line and its integration with the surrounding transportation system" (Aurora, 2014)

- $\quad$ Policy T-2.5: Travel Demand Management "The City will work to increase the use of alternative travel modes for commuting trips through travel demand management strategies including integration with FasTracks corridors, shuttles, and on-call transit services" (Aurora, 2014)

Discussion of RTD follows a similar pattern with an emphasis found in the 2005 Aurora Comprehensive Plan. Specific policies call for the City of Aurora to "actively participate in the planning of the RTD Gold Line and other transit opportunities" and to "coordinate regional transportation efforts of the City, RTD, surrounding cities, and CDOT to help reduce traffic congestion" (Aurora, 2005). Aurora's 2005 plan also references continued coordination with RTD to ensure that proposed transit stations are fully implemented. The sharp increase in discussion of both RTD and FasTracks is directly tied to the regional investment in the build out of light rail and bus rapid stations extending from the city center to suburban communities.

Interviews support the notion that case study communities work closely with RTD in the implementation of FasTracks development, especially on station area planning efforts. Staff with the City of Thornton cited RTD's contribution to the Eastlake at $124^{\text {th }}$ Station Area Master Plan as an example of their work with RTD. Similarly, planning staff at the City of Aurora indicated that they meet with RTD on a weekly basis to discuss the design-build process of the I-225 Rail Line (R Line) and impact on surrounding neighborhoods. 


\subsubsection{Salt Lake City}

Regional visioning in Salt Lake City began at about the same time as the efforts in Denver. However, early activities were led by the nonprofit organization Envision Utah. The primary focus of these efforts was to raise awareness of regional growth trends, examine scenarios for development, and encourage local governments to consider different urban forms to better accommodate future growth.

The Wasatch Front Regional Council did not begin developing a regional strategy until it launched the Wasatch Choice process in 2005 with a set of goals and principles. The final draft of the Wasatch Choice Vision Map and Regional Growth Principles was not adopted until 2010. By comparison, DRCOG had already released its second version of Metro Vision by 2005, and was one year away from releasing the Metro Vision 2035 update.

Not surprisingly, the analysis of local plans in the Salt Lake City region has shown far less reference to the either Envision Utah or Wasatch Choice. Some of this relates to the voluntary nature of these regional plans and the relatively vague regional objectives. Furthermore, the Regional Transportation Plan has not included the same types of incentives for projects serving centers until the 2015-2040 Transportation Improvement Program cycle (Wasatch Front Regional Council, 2016).

For example, Salt Lake City the Northwest Master Plan (1992) references the Wasatch Front Regional Council six times, but it is limited to discussions of transportation planning and rightsof-way. The Sugar House Master Plan (2005) provides more specific references to the WFRC, but the context is transportation and transit planning. By 2015, the city's comprehensive plan includes new guiding principles related to growing responsibility, providing access to a range of housing types and improving mobility. More importantly, the plan develops a more specific initiative related to transit-oriented development along with supporting policies, but there is little reference to the regional council or Wasatch Choice.

\subsection{Goals and Indicators: Policy Crosswalk}

As noted above, the Denver and Salt Lake City regions have both used voluntary approaches based on scenario analysis and a goal of directing more development into metropolitan centers. However, the regions have developed quite different goals, policies and indicators. In the following sections, we summarize and compare the goals and indicators in both regions.

\subsubsection{Denver Metro Vision 2035}

The Denver MetroVision plan includes goals, visions and policies specific to urban centers. Denver is explicit in the role urban centers play in the vision for the region, and DRCOG establishes explicit quantitative targets for the amount of new housing and jobs that should occur in urban centers during the plan horizon (2005-2035.)

\section{Urban Centers Vision}

The Denver metro region will become an international model for healthy, livable communities by developing vibrant urban centers connected by a robust multimodal network throughout the metro area. While each urban center will be unique, all urban centers will: 
- Be active, pedestrian-, bicycle-, and transit-friendly places that are more dense and mixed in use than surrounding areas;

- Allow people of all ages, incomes and abilities to access a range of housing, employment, and service opportunities without sole reliance on having to drive; and

- Promote regional sustainability by reducing per capita vehicle miles traveled.

Urban Centers Goal: $\mathbf{5 0 \%}$ new housing units and $75 \%$ of new jobs within urban centers

- Policy 3: Metro Vision encourages the development of urban centers at infill and redevelopment sites within the UGB/A throughout the metro area.

- Policy 3: Metro Vision prioritizes urban centers around existing or proposed transit stations or with high-frequency bus service.

- Policy 4: Urban centers will have high levels of internal connectivity and will be well connected to the region at large.

- Policy 5: Urban centers will support housing suitable for a wide range of incomes and the full spectrum of life stages and physical abilities, providing good links to jobs, services and other opportunities and reducing the combined cost of housing and transportation.

- Policy 6: Modes such as walking, bicycling and transit will be equally competitive with driving within urban centers (DRCOG, 2007, 17).

\subsubsection{Wasatch Choice 2040}

In Wasatch Choice 2040, centers play a much different role. Six different types of centers are designated on the 2040 vision map, and are defined as "historical and emerging regional destinations of economic activity." As noted on the map, "The vision suggests that these centers should expand to provide ever-broadening choices for residents to live, work, shop and play; a mix of all of these activities is welcome” (Wasatch Choice for 2040 Vision Map).

However, WFRC does not establish quantitative targets or center-specific visions. The plan includes nine broad principles and designates objectives for each principle. Five of the objectives under four different principles mention centers. As noted, the policies are much broader and less direct than Denver's policies.

\section{Principle 2: Relevant Principle: Provide Regional Mobility through a Variety of} Interconnected Transportation Choices.

- Objective b: Coordinate transportation with regional employment, housing, educational and activity centers.

Principle 3: Integrate Local Land-Use with Regional Transportation Systems

- Objective c: Coordinate regional transportation with centers of development.

- Objective d: Coordinate transportation decisions with schools and educational centers.

Principle 4: Provide Housing for People in all Life Stages and Incomes

- Objective a: Encourage an adequate supply of moderately priced housing near regional job centers.

Principle 8: Strengthen Sense of Community

- Objective 8d: Use transportation to bolster town centers (Wasatch Choices 2040: Principles of the Vision). 
To help evaluate implementation related to these goals, principles and objectives, we numbered each principle and objective to create the policy crosswalk. Figure 6-2 integrates the principles from Wasatch Choices, the goals, visions and policies from DRCOG's Metro Vision and links them to metrics identified by the research team for evaluating the performance of urban centers in both regions over time. Data sources for each metric are described in Appendix B.

Figure 6-2: Metropolitan Center Comparison

\begin{tabular}{|c|c|c|}
\hline $\begin{array}{l}\text { Wasatch Choices for } 2040 \\
\text { Principles and Objectives }\end{array}$ & Indicators Identified by Researchers & $\begin{array}{l}\text { DRCOG Metro Vision } \\
\text { 2035: Urban Centers }\end{array}$ \\
\hline \multicolumn{3}{|l|}{ DEMOGRAPHICS } \\
\hline & Population & G1 \\
\hline & Jobs & G1, V2 \\
\hline & Household income & V2, P5 \\
\hline $4 \mathrm{a}$ & Number of Housing Units & V2, P5 \\
\hline \multicolumn{3}{|l|}{ LAND USE } \\
\hline & Land Use Mix & V1 \\
\hline & Vacancy & P3A \\
\hline $4 a$ & Housing Tenure & P5 \\
\hline \multirow[t]{2}{*}{$4 \mathrm{a}$} & Housing Value & V2, P5 \\
\hline & Year built & P3A \\
\hline \multicolumn{3}{|l|}{ TRANSPORTATION } \\
\hline $2 b, 3 c, 3 d, 8 d$ & Bus stops & V1, V2, V3, P3B, P4, P6 \\
\hline $2 b, 3 c, 3 d, 8 d$ & Bus Routes & $\mathrm{V} 1, \mathrm{~V} 2, \mathrm{~V} 3, \mathrm{P} 3 \mathrm{~B}, \mathrm{P} 4, \mathrm{P} 6$ \\
\hline $2 b, 3 c, 3 d, 8 d$ & Percent who take public transit & $\mathrm{V} 1, \mathrm{~V} 2, \mathrm{~V} 3, \mathrm{P} 6$ \\
\hline $2 b, 3 c, 3 d, 8 d$ & $\begin{array}{l}\text { Average number of vehicles available } \\
\text { per household }\end{array}$ & V1,V2,V3,P6 \\
\hline $2 b, 3 c, 3 d, 8 d$ & Number Public Transit/Walk/Bike & V1,V2,V3,P6 \\
\hline $2 b, 3 c, 3 d, 8 d$ & Commute Time & V3 \\
\hline $2 b, 3 c, 3 d, 8 d$ & Cul-de-sacs & $\mathrm{V} 1, \mathrm{~V} 2, \mathrm{P} 4, \mathrm{P} 6$ \\
\hline $2 b, 3 c, 3 d, 8 d$ & Cul-de-sac ratio & $\mathrm{V} 1, \mathrm{~V} 2, \mathrm{P} 4, \mathrm{P} 6$ \\
\hline $2 b, 3 c, 3 d, 8 d$ & Street length & $\mathrm{V} 1, \mathrm{~V} 2, \mathrm{P} 4, \mathrm{P} 6$ \\
\hline $2 b, 3 c, 3 d, 8 d$ & Average block length & $\mathrm{V} 1, \mathrm{~V} 2, \mathrm{P} 4, \mathrm{P} 6$ \\
\hline
\end{tabular}

*Note - researchers were not able to acquire data for italicized indicators and plan to study these measures in future work.

\subsection{Metropolitan Centers}

The concept of metropolitan centers has also demonstrated an evolution over time. In both regions, we noted two changes in local plans over different phases of regional planning efforts. Since there are no requirements in either state for comprehensive plans, not all jurisdictions had plans in each period to examine. In several cases, the city or town was not incorporated, and we examined county plans. We also reviewed neighborhood plans in several cities where this constituted a key part of their planning framework. 


\subsubsection{Use of Centers-Related Terminology}

In Denver, we examined the evolution of local plans over three time periods (when available). We began with plans created in what we have called Generation 1, which is the time period prior to the start of regional planning efforts (Metro Vision 2020). We also analyzed plans during Generation 2, which was after the first regional planning effort. Finally, we examined plans during Generation 3, which were plans prepared after subsequent regional planning efforts (Metro Vision 2030 and Metro Vision 2035).

In Salt Lake City, we examined the evolution of local plans over three time periods when possible. Plans adopted prior to Envision Utah (1999), plans created after Envision Utah (20002009) and plans created after the creation of Wasatch Choice 2040 Vision (2010). Overall, there have been relatively fewer comprehensive plans prepared in the Salt Lake City region and only a handful of plans have been created after 2010.

In both regions, we found increased use of centers-related terminology over time. In Denver, there has been a significant increase in the use of centers and related terminology over time. Early use of centers terminology often referred to a concentration of activity (employment or retail) while later references aligned more closely with the Metro Vision image of concentrated mixed-use development. Transit-oriented development (TOD) terminology and planning districts also emerged strongly in third-generation plans. This trend can be found across case study communities and is clearly illustrated by scores recorded in Figure 6-3. 
Figure 6-3: Plan Evaluation Summary-Denver

\begin{tabular}{|c|c|c|c|c|c|c|}
\hline \multirow[t]{2}{*}{ Jurisdiction } & \multirow[t]{2}{*}{ Category } & \multirow[t]{2}{*}{ Search Term } & $\begin{array}{c}\text { Generation 1: } \\
\text { Approx 1985-1996 } \\
\end{array}$ & $\begin{array}{c}\text { Generation 2: Approx } \\
\text { 1997-2004 } \\
\end{array}$ & \multicolumn{2}{|c|}{$\begin{array}{c}\text { Generation 1: Approx } \\
\text { 2005-2015 }\end{array}$} \\
\hline & & & 1989 Comp Plan & 1998 Comp Plan & $2009 \mathrm{Co}$ & Plan \\
\hline \multirow{15}{*}{ Aurora } & \multirow{11}{*}{\begin{tabular}{|l|} 
\\
Urban Center \\
Related Terms
\end{tabular}} & Regional Center & 0 & 1 & & \\
\hline & & \begin{tabular}{|l|} 
Community Center \\
\end{tabular} & 0 & 2 & & \\
\hline & & Neighorhood Center & 0 & 1 & & \\
\hline & & \begin{tabular}{|l|l} 
Urban Center \\
\end{tabular} & 0 & 1 & & \\
\hline & & \begin{tabular}{|l|} 
Employment Center \\
\end{tabular} & 1 & 1 & & \\
\hline & & Regional Activity Center & 0 & 0 & & \\
\hline & & \begin{tabular}{|l} 
Community Activity Center \\
\end{tabular} & 0 & 0 & & \\
\hline & & Neighborhood Activity Center & 0 & 0 & & \\
\hline & & \begin{tabular}{|l|} 
Urban Activity Center \\
\end{tabular} & 0 & 0 & & \\
\hline & & \begin{tabular}{|l|} 
Multi-Purpose Center \\
\end{tabular} & 0 & 0 & & \\
\hline & & $\begin{array}{l}\text { Transit Oriented Development } \\
\text { (TOD) }\end{array}$ & 0 & 0 & & \\
\hline & \multirow{2}{*}{\begin{tabular}{|l|} 
Plan \& \\
Program Terms \\
\end{tabular}} & FasTracks & 0 & 0 & & \\
\hline & & \begin{tabular}{|l|} 
MetroVision \\
\end{tabular} & 0 & 3 & & \\
\hline & \multirow{2}{*}{ Agency Terms } & \begin{tabular}{|l|} 
Denver Regional Council of \\
Governments (DRCOG) \\
\end{tabular} & 1 & 1 & & \\
\hline & & \begin{tabular}{|l|} 
Regional Transportation District \\
(RTD)
\end{tabular} & 1 & 1 & & \\
\hline & & & 1985 Comp Plan & $\begin{array}{l}1997 \text { Comp Plan (Amended in } \\
\text { 2003) }\end{array}$ & 2007 Comp Plan & $\begin{array}{l}2012 \text { Comp } \\
\text { Plan }\end{array}$ \\
\hline \multirow{15}{*}{ Thornton } & \multirow{11}{*}{\begin{tabular}{|l} 
\\
Urban Center \\
Related Terms
\end{tabular}} & Regional Center & 0 & 0 & 0 & 0 \\
\hline & & \begin{tabular}{|l|} 
Community Center \\
\end{tabular} & $0^{*}$ & $0^{*}$ & $0^{*}$ & $0^{*}$ \\
\hline & & Neighorhood Center & 1 & 0 & 0 & 0 \\
\hline & & \begin{tabular}{|l|} 
Urban Center \\
\end{tabular} & 0 & 1 & 0 & 1 \\
\hline & & Employment Center & 0 & 1 & 2 & 2 \\
\hline & & Regional Activity Center & 0 & 0 & 0 & 0 \\
\hline & & \begin{tabular}{|l|} 
Community Activity Center \\
\end{tabular} & 0 & 0 & 0 & 0 \\
\hline & & \begin{tabular}{|l} 
Neighborhood Activity Center \\
\end{tabular} & 0 & 0 & 0 & 0 \\
\hline & & \begin{tabular}{|l|l|} 
Urban Activity Center \\
\end{tabular} & 0 & 0 & 0 & 0 \\
\hline & & Multi-Purpose Center & 1 & 0 & 0 & 0 \\
\hline & & $\begin{array}{l}\begin{array}{l}\text { Transit Oriented Development } \\
\text { (TOD) }\end{array} \\
\end{array}$ & 0 & 0 & 2 & 3 \\
\hline & \multirow{2}{*}{\begin{tabular}{|l|} 
Plan \& \\
Program Terms \\
\end{tabular}} & FasTracks & 0 & 0 & 2 & 2 \\
\hline & & \begin{tabular}{|l|} 
MetroVision \\
\end{tabular} & 0 & 0 & \multirow[t]{2}{*}{1} & \multirow[t]{2}{*}{1} \\
\hline & \multirow{2}{*}{ Agency Terms } & \begin{tabular}{|l|}
$\begin{array}{l}\text { Denver Regional Council of } \\
\text { Governments (DRCOG) }\end{array}$ \\
\end{tabular} & 1 & 2 & & \\
\hline & & $\begin{array}{l}\begin{array}{l}\text { Regional Transportation District } \\
\text { (RTD) }\end{array} \\
\end{array}$ & 1 & 1 & 2 & 1 \\
\hline
\end{tabular}


Figure 6-3: Plan Evaluation Summary-Denver (Continued)

\begin{tabular}{|c|c|c|c|c|c|}
\hline Jurisdiction | & Category & Search Term & $\begin{array}{c}\text { Generation 1: } \\
\text { Approx 1985-1996 }\end{array}$ & $\begin{array}{c}\text { Generation 2: Approx } \\
\text { 1997-2004 }\end{array}$ & $\begin{array}{l}\text { Generation 1: Approx } \\
\text { 2005-2015 }\end{array}$ \\
\hline & & & 1989 Comp Plan & No Plan & $\begin{array}{l}2004 \text { Comp Plan (Amended in } \\
\text { 2012) }\end{array}$ \\
\hline \multirow{15}{*}{$\begin{array}{c}\text { Greenwood } \\
\text { Village }\end{array}$} & \multirow{11}{*}{$\begin{array}{l}\text { Urban Center } \\
\text { Related Terms }\end{array}$} & Regional Center & 0 & & 0 \\
\hline & & Community Center & 0 & & 0 \\
\hline & & Neighorhood Center & 0 & & 1 \\
\hline & & Urban Center & 0 & & 1 \\
\hline & & Employment Center & 0 & & 1 \\
\hline & & Regional Activity Center & 0 & & 0 \\
\hline & & Community Activity Center & 0 & & 0 \\
\hline & & Neighborhood Activity Center & 0 & & 0 \\
\hline & & Urban Activity Center & 0 & & 0 \\
\hline & & Multi-Purpose Center & 0 & & 0 \\
\hline & & $\begin{array}{l}\text { Transit Oriented Development } \\
\text { (TOD) }\end{array}$ & 0 & & 1 \\
\hline & \multirow{2}{*}{\begin{tabular}{|l|} 
Plan \& \\
Program Terms
\end{tabular}} & FasTracks & 0 & & 0 \\
\hline & & MetroVision & 0 & & 2 \\
\hline & \multirow{2}{*}{ Agency Terms } & \begin{tabular}{|l|} 
Denver Regional Council of \\
Governments (DRCOG)
\end{tabular} & 1 & & 1 \\
\hline & & $\begin{array}{l}\text { Regional Transportation District } \\
\text { (RTD) }\end{array}$ & 1 & & 1 \\
\hline & & & 1996 Comp Plan & No Plan & 2008 Comp Plan \\
\hline \multirow{15}{*}{ Lone Tree } & \multirow{11}{*}{$\begin{array}{l}\text { Urban Center } \\
\text { Related Terms }\end{array}$} & Regional Center & 0 & & 0 \\
\hline & & Community Center & 0 & & 0 \\
\hline & & Neighorhood Center & 1 & & 0 \\
\hline & & Urban Center & 0 & & 0 \\
\hline & & Employment Center & 0 & & 0 \\
\hline & & Regional Activity Center & 0 & & 0 \\
\hline & & Community Activity Center & 0 & & 0 \\
\hline & & Neighborhood Activity Center & 0 & & 0 \\
\hline & & Urban Activity Center & 0 & & 0 \\
\hline & & Multi-Purpose Center & 0 & & 0 \\
\hline & & $\begin{array}{l}\text { Transit Oriented Development } \\
\text { (TOD) }\end{array}$ & 0 & & 3 \\
\hline & \multirow{2}{*}{\begin{tabular}{|l|} 
Plan \& \\
Program Terms \\
\end{tabular}} & FasTracks & 0 & & 3 \\
\hline & & MetroVision & 0 & & 1 \\
\hline & \multirow{2}{*}{ Agency Terms } & \begin{tabular}{|l} 
Denver Regional Council of \\
Governments (DRCOG) \\
\end{tabular} & 0 & & 1 \\
\hline & & $\begin{array}{l}\text { Regional Transportation District } \\
\text { (RTD) }\end{array}$ & 1 & & 1 \\
\hline
\end{tabular}


Figure 6-3: Plan Evaluation Summary-Denver (Continued)

\begin{tabular}{|c|c|c|c|c|c|c|}
\hline Jurisdiction & Category & Search Term & $\begin{array}{c}\text { Generation 1: } \\
\text { Approx 1985-1996 }\end{array}$ & $\begin{array}{r}\text { Generatior } \\
1997 .\end{array}$ & $\begin{array}{l}\text { 2: Approx } \\
\text {-2004 }\end{array}$ & $\begin{array}{l}\text { Generation 1: Approx } \\
\text { 2005-2015 }\end{array}$ \\
\hline & & & 1989 Comp Plan & 2000 Comp Plan & $\begin{array}{c}2003 \text { Baker } \\
\text { Neighborhood } \\
\text { Plan } \\
\end{array}$ & $\begin{array}{l}2008 \text { University Park } \\
\text { Neighborhood Plan }\end{array}$ \\
\hline \multirow{16}{*}{ Denver } & \multirow{11}{*}{$\begin{array}{l}\text { Urban Center } \\
\text { Related Terms }\end{array}$} & Regional Center & 1 & 0 & 0 & 0 \\
\hline & & Community Center & 0 & $0^{*}$ & $0^{*}$ & 0 \\
\hline & & Neighorhood Center & 1 & 0 & 1 & 0 \\
\hline & & Urban Center & 0 & 3 & 0 & 1 \\
\hline & & Employment Center & 2 & 1 & 1 & 0 \\
\hline & & Regional Activity Center & 0 & 0 & 0 & 0 \\
\hline & & \begin{tabular}{|l} 
Community Activity Center \\
\end{tabular} & 0 & 0 & 0 & 0 \\
\hline & & Neighborhood Activity Center & 0 & 0 & 0 & 0 \\
\hline & & Urban Activity Center & 0 & 0 & 0 & 0 \\
\hline & & Multi-Purpose Center & 0 & 0 & 0 & 0 \\
\hline & & $\begin{array}{l}\begin{array}{l}\text { Transit Oriented Development } \\
\text { (TOD) }\end{array} \\
\end{array}$ & 0 & 2 & 3 & 3 \\
\hline & \multirow{2}{*}{\begin{tabular}{|l|} 
Plan \& \\
Program Terms \\
\end{tabular}} & FasTracks & 0 & 0 & 0 & 0 \\
\hline & & MetroVision & 0 & 3 & 0 & 0 \\
\hline & \multirow{2}{*}{ Agency Terms } & $\begin{array}{l}\text { Denver Regional Council of } \\
\text { Governments (DRCOG) }\end{array}$ & 2 & 2 & 0 & 1 \\
\hline & & $\begin{array}{l}\text { Regional Transportation District } \\
\text { (RTD) }\end{array}$ & 1 & 1 & 2 & 2 \\
\hline & & & 1987 Comp Plan & \multicolumn{2}{|c|}{2003 Comp Plan } & 2015 Comp Plan \\
\hline \multirow{15}{*}{ Lakewood } & \multirow{11}{*}{$\begin{array}{l}\text { Urban Center } \\
\text { Related Terms }\end{array}$} & Regional Center & 0 & 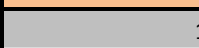 & 1 & 0 \\
\hline & & \begin{tabular}{|l} 
Community Center \\
\end{tabular} & 0 & ( & 0 & $0^{*}$ \\
\hline & & \begin{tabular}{|l|} 
Neighorhood Center \\
\end{tabular} & 0 & 2 & 2 & 2 \\
\hline & & \begin{tabular}{|l} 
Urban Center \\
\end{tabular} & 0 & 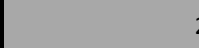 & 2 & 1 \\
\hline & & \begin{tabular}{|l} 
Employment Center \\
\end{tabular} & 1 & 2 & 2 & 1 \\
\hline & & Regional Activity Center & 0 & ( & 0 & 0 \\
\hline & & \begin{tabular}{|l|} 
Community Activity Center \\
\end{tabular} & 0 & ( & 0 & 0 \\
\hline & & Neighborhood Activity Center & 0 & rat & 0 & 0 \\
\hline & & \begin{tabular}{|l} 
Urban Activity Center \\
\end{tabular} & 0 & rat & 0 & 0 \\
\hline & & \begin{tabular}{|l|} 
Multi-Purpose Center \\
\end{tabular} & 0 & ( & 0 & 0 \\
\hline & & $\begin{array}{l}\begin{array}{l}\text { Transit Oriented Development } \\
\text { (TOD) }\end{array} \\
\end{array}$ & 0 & 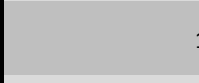 & 1 & 3 \\
\hline & \multirow{2}{*}{\begin{tabular}{|l|} 
Plan \& \\
Program Terms
\end{tabular}} & FasTracks & 0 & ( & 0 & 0 \\
\hline & & MetroVision & 0 & ( & 0 & 1 \\
\hline & \multirow{2}{*}{ Agency Terms } & $\begin{array}{l}\text { Denver Regional Council of } \\
\text { Governments (DRCOG) }\end{array}$ & 1 & 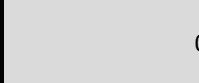 & 0 & 1 \\
\hline & & \begin{tabular}{|l|} 
Regional Transportation District \\
(RTD)
\end{tabular} & 1 & 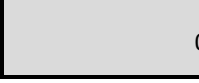 & 0 & 3 \\
\hline
\end{tabular}


Figure 6-3: Plan Evaluation Summary-Denver (Continued)

\begin{tabular}{|c|c|c|c|c|c|c|c|}
\hline \multirow[t]{2}{*}{ Jurisdiction } & \multirow[t]{2}{*}{ Category } & \multirow[t]{2}{*}{ Search Term } & \multicolumn{2}{|c|}{$\begin{array}{c}\text { Generation 1: } \\
\text { Approx 1985-1996 }\end{array}$} & $\begin{array}{c}\text { Generation 2: Approx } \\
\text { 1997-2004 }\end{array}$ & \multicolumn{2}{|c|}{$\begin{array}{l}\text { Generation 1: Approx } \\
\text { 2005-2015 }\end{array}$} \\
\hline & & & $\begin{array}{l}1985 \text { Comp } \\
\text { Plan }\end{array}$ & $\begin{array}{l}1995 \text { Comp } \\
\text { Plan }\end{array}$ & No Plan & 2005 Comp Plan & $\begin{array}{l}2014 \text { Comp } \\
\text { Plan }\end{array}$ \\
\hline \multirow{15}{*}{ Arvada } & \multirow{11}{*}{$\begin{array}{l}\text { Urban Center } \\
\text { Related Terms }\end{array}$} & Regional Center & 0 & 0 & & 0 & 0 \\
\hline & & Community Center & $0^{*}$ & 0 & & $0^{*}$ & 0* \\
\hline & & Neighorhood Center & $0^{*}$ & 0 & & 0 & 0 \\
\hline & & Urban Center & 0 & 2 & & 1 & 2 \\
\hline & & Employment Center & 0 & 0 & & 1 & 1 \\
\hline & & Regional Activity Center & 0 & 1 & & 0 & 0 \\
\hline & & Community Activity Center & 0 & 0 & & 0 & 0 \\
\hline & & Neighborhood Activity Center & 0 & 0 & & 0 & 0 \\
\hline & & Urban Activity Center & 0 & 1 & & 1 & 0 \\
\hline & & Multi-Purpose Center & $0^{*}$ & 0 & & 0 & 0 \\
\hline & & $\begin{array}{l}\text { Transit Oriented Development } \\
\text { (TOD) }\end{array}$ & 0 & 1 & & 2 & 3 \\
\hline & \multirow{2}{*}{\begin{tabular}{|l|} 
Plan \& \\
Program Terms \\
\end{tabular}} & FasTracks & 0 & 0 & & 1 & 2 \\
\hline & & MetroVision & 0 & 1 & & 2 & 1 \\
\hline & \multirow{2}{*}{ Agency Terms } & \begin{tabular}{|l} 
Denver Regional Council of \\
Governments (DRCOG)
\end{tabular} & 1 & 1 & & 3 & 2 \\
\hline & & $\begin{array}{l}\text { Regional Transportation District } \\
\text { (RTD) }\end{array}$ & 2 & 2 & & 3 & 2 \\
\hline & & & & & 1997 Comp Plan & \begin{tabular}{|c|}
2004 Comp Plan \\
(updated in 2008)
\end{tabular} & $\begin{array}{l}2014 \text { Comp } \\
\text { Plan }\end{array}$ \\
\hline \multirow{15}{*}{ Westminster } & \multirow{11}{*}{$\begin{array}{l}\text { Urban Center } \\
\text { Related Terms }\end{array}$} & Regional Center & & & 0 & 0 & 0 \\
\hline & & Community Center & & & $0^{*}$ & $0^{*}$ & $0^{*}$ \\
\hline & & Neighorhood Center & & & 1 & 2 & 1 \\
\hline & & Urban Center & & & 0 & 0 & 1 \\
\hline & & Employment Center & & & 2 & 2 & 1 \\
\hline & & Regional Activity Center & & & 0 & 0 & 0 \\
\hline & & Community Activity Center & & & 0 & 1 & 1 \\
\hline & & Neighborhood Activity Center & & & 0 & 0 & 1 \\
\hline & & Urban Activity Center & & & 0 & 1 & 0 \\
\hline & & \begin{tabular}{|l} 
Multi-Purpose Center \\
\end{tabular} & & & 0 & 0 & 0 \\
\hline & & $\begin{array}{l}\text { Transit Oriented Development } \\
\text { (TOD) }\end{array}$ & & & 0 & 3 & 1 \\
\hline & \multirow{2}{*}{\begin{tabular}{|l} 
Plan \& \\
Program Terms \\
\end{tabular}} & FasTracks & & & 0 & 1 & 2 \\
\hline & & MetroVision & & & 1 & 1 & 1 \\
\hline & \multirow{2}{*}{ Agency Terms } & $\begin{array}{l}\text { Denver Regional Council of } \\
\text { Governments (DRCOG) }\end{array}$ & & & 1 & 1 & 1 \\
\hline & & $\begin{array}{l}\text { Regional Transportation District } \\
\text { (RTD) }\end{array}$ & & & 1 & 2 & 3 \\
\hline
\end{tabular}


Figure 6-3: Plan Evaluation Summary-Denver (Continued)

\begin{tabular}{|c|c|c|c|c|c|}
\hline Jurisdiction & Category & Search Term & $\begin{array}{c}\text { Generation 1: } \\
\text { Approx 1985-1996 }\end{array}$ & $\begin{array}{c}\text { Generation 2: Approx } \\
\text { 1997-2004 } \\
\end{array}$ & $\begin{array}{c}\text { Generation 1: Approx } \\
\text { 2005-2015 }\end{array}$ \\
\hline & & & 1979 Comp Plan & 2003 Comp Plan & 2015 Draft Comp Plan \\
\hline \multirow{15}{*}{ Englewood } & \multirow{11}{*}{$\begin{array}{l}\text { Urban Center } \\
\text { Related Terms }\end{array}$} & Regional Center & 0 & 0 & 0 \\
\hline & & Community Center & 0* & 0 & 1 \\
\hline & & Neighorhood Center & 0 & 0 & 0 \\
\hline & & \begin{tabular}{|l|} 
Urban Center \\
\end{tabular} & 0 & 2 & 1 \\
\hline & & Employment Center & 1 & 0 & 2 \\
\hline & & Regional Activity Center & 1 & 0 & 0 \\
\hline & & Community Activity Center & 0 & 0 & 0 \\
\hline & & Neighborhood Activity Center & 0 & 0 & 0 \\
\hline & & Urban Activity Center & 0 & 0 & 0 \\
\hline & & Multi-Purpose Center & 1 & 0 & 0 \\
\hline & & $\begin{array}{l}\text { Transit Oriented Development } \\
\text { (TOD) }\end{array}$ & 0 & 1 & 1 \\
\hline & \multirow{2}{*}{\begin{tabular}{|l|} 
Plan \& \\
Program Terms \\
\end{tabular}} & FasTracks & 0 & 0 & 0 \\
\hline & & MetroVision & 0 & 2 & 1 \\
\hline & \multirow{2}{*}{ Agency Terms } & $\begin{array}{l}\text { Denver Regional Council of } \\
\text { Governments (DRCOG) }\end{array}$ & 0 & 2 & 1 \\
\hline & & $\begin{array}{l}\begin{array}{l}\text { Regional Transportation District } \\
\text { (RTD) }\end{array} \\
\end{array}$ & 2 & 1 & 1 \\
\hline & & & $\begin{array}{c}1985 \text { Arapahoe County Comp } \\
\text { Plan }\end{array}$ & 2004 Centential Comp Plan & No Plan \\
\hline \multirow{15}{*}{ Centennial } & \multirow{11}{*}{$\begin{array}{l}\text { Urban Center } \\
\text { Related Terms }\end{array}$} & Regional Center & $\overline{0}$ & 0 & \\
\hline & & Community Center & 0 & 0 & \\
\hline & & Neighorhood Center & 0 & 0 & \\
\hline & & Urban Center & 0 & 1 & \\
\hline & & Employment Center & 1 & 0 & \\
\hline & & Regional Activity Center & 1 & 0 & \\
\hline & & Community Activity Center & 0 & 0 & \\
\hline & & Neighborhood Activity Center & 1 & 0 & \\
\hline & & $\begin{array}{l}\text { Urban Activity Center } \\
\end{array}$ & 0 & 0 & \\
\hline & & \begin{tabular}{|l} 
Multi-Purpose Center \\
\end{tabular} & 0 & 0 & \\
\hline & & $\begin{array}{l}\text { Transit Oriented Development } \\
\text { (TOD) }\end{array}$ & 0 & 1 & \\
\hline & \multirow{2}{*}{\begin{tabular}{|l|} 
Plan \& \\
Program Terms
\end{tabular}} & FasTracks & 0 & 0 & \\
\hline & & MetroVision & 0 & 1 & \\
\hline & \multirow{2}{*}{ Agency Terms } & $\begin{array}{l}\text { Denver Regional Council of } \\
\text { Governments (DRCOG) }\end{array}$ & 1 & 1 & \\
\hline & & $\begin{array}{l}\text { Regional Transportation District } \\
\text { (RTD) }\end{array}$ & 1 & 1 & \\
\hline
\end{tabular}


In Denver, the definition of centers varied over time at the regional level as well. In Metro Vision 2030 (2005), categories included activity centers, corridors and mixed-use centers. In Metro Vision 2035 (2011), centers are designated as planned, existing or emerging. Some of the existing centers offer little more than a rail station. Many emerging centers are essentially greenfield sites. Furthermore, centers are not required to contain a fixed transit station. For example, the Candelas urban center (located in Arvada) is designated as a center by Metro Vision 2035 but is not served by RTD light rail. Interviews with Thornton planning staff revealed that Thornton City Center and I-25/ Highway 7 (two of the city's four designated urban centers) have low potential of developing as true mixed-use centers. In both instances, the incentive for designating these centers was access to TIP funding.

\section{Figure 6-4: I-25/ Highway 7 Urban Center -Thornton, CO}

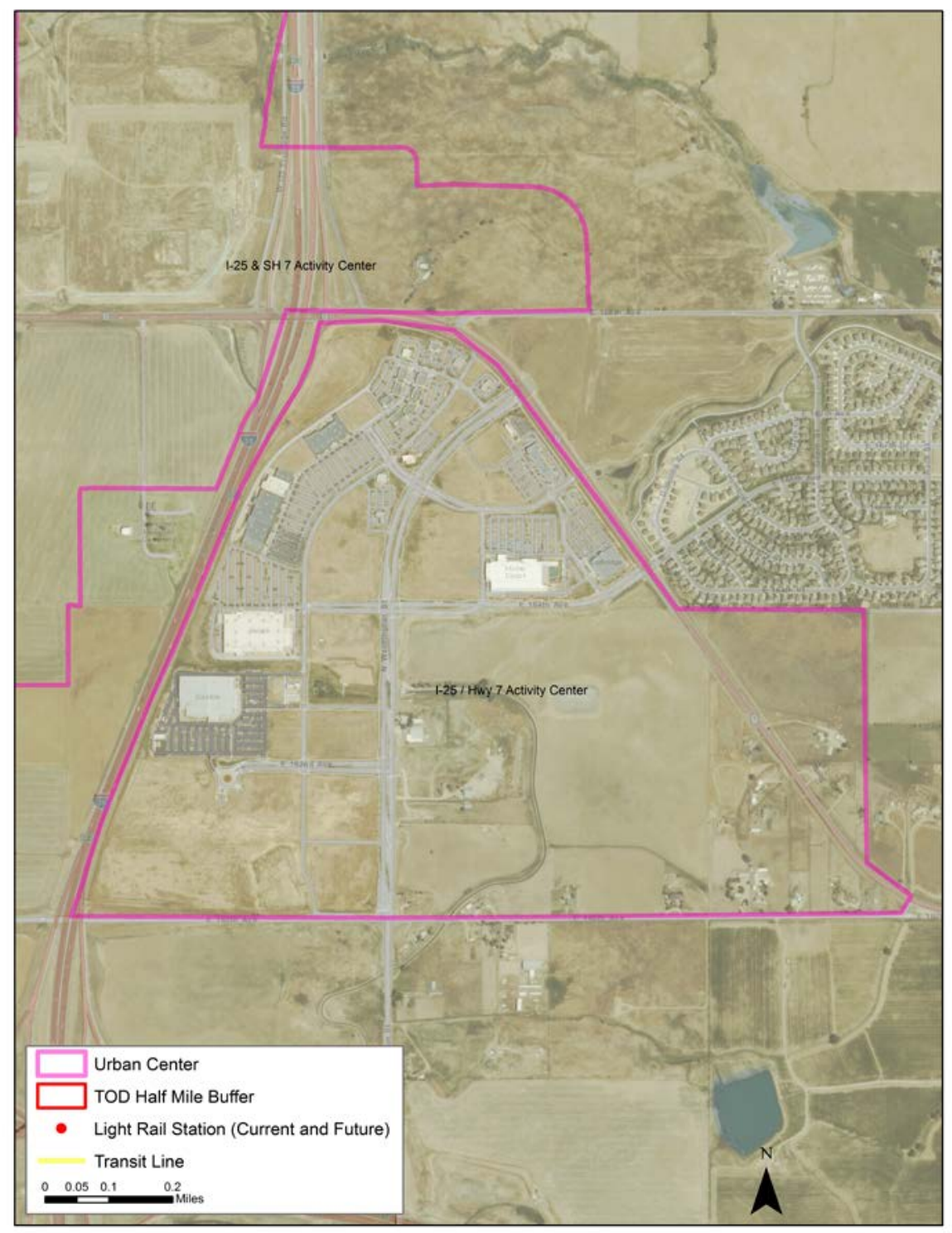


Figure 6-5: Candelas Master-Planned Community -Arvada, CO

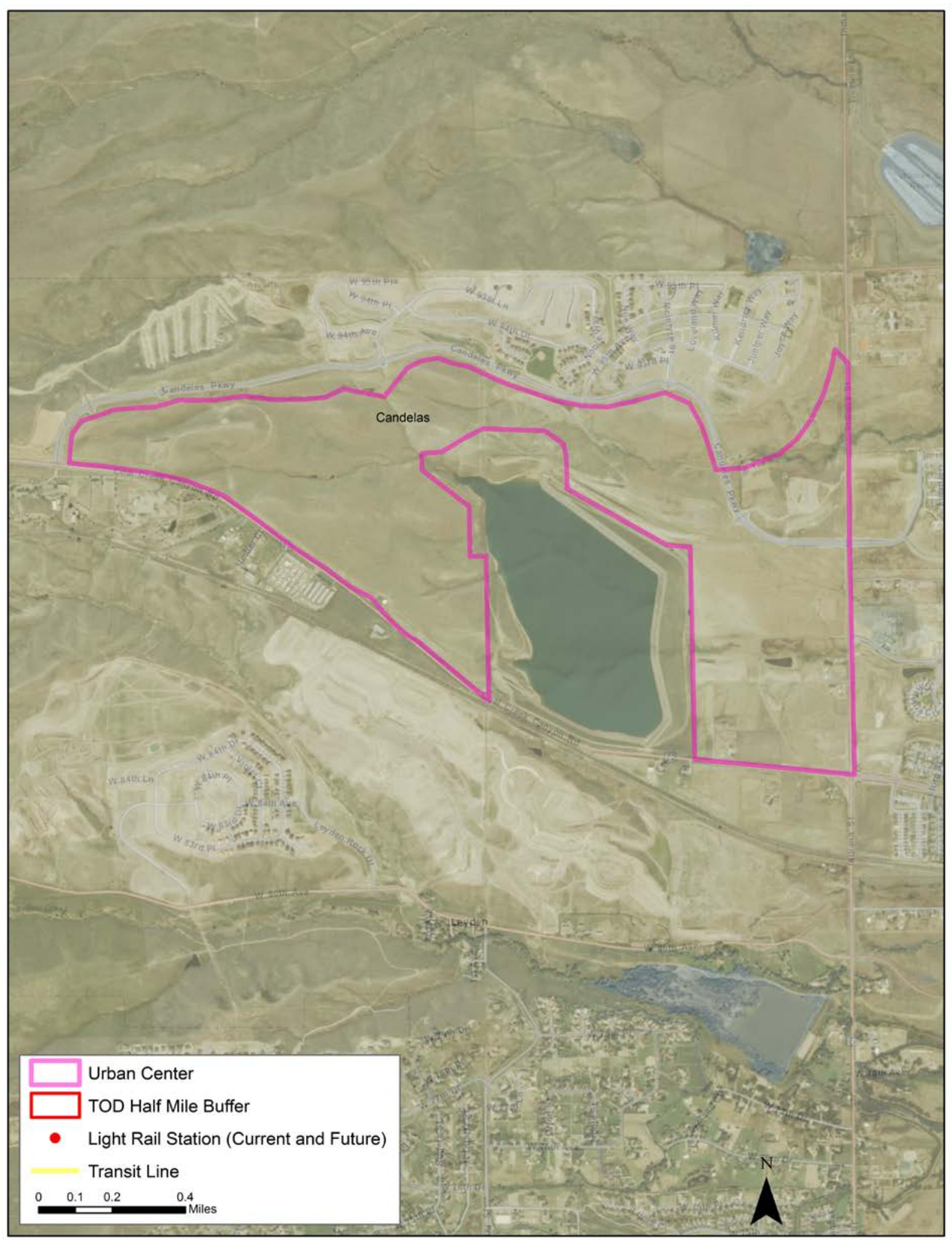


In Salt Lake City, the number of instances of the word "center" appearing in general plans has increased in several jurisdictions. In the first two periods of General Plan analysis (before 2000, and between 2000 and 2010), the majority of the mentions of centers dealt loosely with the concept of centers of employment or commercial development. However, overall the depth and extent to which they have developed supporting policies has varied considerably. A number of jurisdictions that have undergone a third phase of planning have built on the concept of centers as a key urban planning strategy. 
Figure 6-6: Plan Evaluation Summary-Salt Lake City

\begin{tabular}{|c|c|c|c|c|c|c|}
\hline \multirow[t]{2}{*}{ Jurisdiction } & \multirow[t]{2}{*}{ Category } & \multirow[t]{2}{*}{ Search Term } & \multicolumn{2}{|c|}{$\begin{array}{c}\text { Generation 1: } \\
\text { Approx 1985-1998 }\end{array}$} & \multirow{2}{*}{$\begin{array}{c}\text { Generation 2: Approx } \\
1999-2009 \\
\begin{array}{c}2001 \text { Sugar House Master Plan } \\
\text { (updated in 2005) }\end{array}\end{array}$} & \multirow{2}{*}{$\begin{array}{c}\text { Generation 3: Approx } \\
\text { 2010-2015 } \\
2015 \text { Citywide Vision }\end{array}$} \\
\hline & & & $\begin{array}{c}1992 \\
\text { Northwest } \\
\text { Master Plan } \\
\end{array}$ & $\begin{array}{l}1993 \text { Strategic } \\
\text { Plan }\end{array}$ & & \\
\hline \multirow{17}{*}{$\begin{array}{l}\text { Salt Lake } \\
\text { City }\end{array}$} & \multirow{10}{*}{$\begin{array}{l}\text { Urban Center } \\
\text { Related Terms }\end{array}$} & Metropolitan Center & 0 & 0 & 0 & 0 \\
\hline & & Urban Center & 0 & 0 & 1 & 0 \\
\hline & & Town Center & 0 & 0 & 3 & 0 \\
\hline & & \begin{tabular}{|l} 
Station Community \\
\end{tabular} & 0 & 0 & 0 & 0 \\
\hline & & Main Street Community & 0 & 0 & 0 & 0 \\
\hline & & Boulevard Community & 0 & 0 & 0 & 0 \\
\hline & & Employment/ Job Center & 1 & 0 & 0 & 0 \\
\hline & & Transit Station Village & 0 & 0 & 0 & 0 \\
\hline & & \begin{tabular}{|l|} 
Growth Center \\
\end{tabular} & 1 & 0 & 0 & 0 \\
\hline & & $\begin{array}{l}\text { Transit Oriented Development } \\
\text { (TOD) }\end{array}$ & 0 & 0 & 2 & 1 \\
\hline & \multirow{4}{*}{\begin{tabular}{|c|} 
Plan \& \\
Program Terms \\
\end{tabular}} & Wasatch Choice for 2040 & 0 & 0 & 0 & 0 \\
\hline & & \begin{tabular}{|l|} 
Envision Utah \\
\end{tabular} & 0 & 0 & 0 & 0 \\
\hline & & TRAX & 0 & 0 & 2 & 0 \\
\hline & & FrontRunner & 0 & 0 & 0 & 0 \\
\hline & \multirow{2}{*}{ Agency Terms } & $\begin{array}{l}\begin{array}{l}\text { Wasatch Front Regional Council } \\
\text { (WFRC) }\end{array} \\
\end{array}$ & 1 & 0 & 1 & 0 \\
\hline & & \begin{tabular}{|l|} 
Mountainland Association of \\
Governments \\
\end{tabular} & 0 & 0 & 0 & 0 \\
\hline & & & $1996 \mathrm{Ge}$ & ieral Plan & 2001 General Plan & 2011 General Plan \\
\hline \multirow{16}{*}{ Lehi } & \multirow{10}{*}{$\begin{array}{c} \\
\text { Urban Center } \\
\text { Related Terms }\end{array}$} & Metropolitan Center & \multicolumn{2}{|c|}{0} & 0 & 0 \\
\hline & & \begin{tabular}{|l|} 
Urban Center \\
\end{tabular} & \multicolumn{2}{|c|}{0} & 0 & 0 \\
\hline & & Town Center & \multicolumn{2}{|c|}{0} & 0 & 1 \\
\hline & & Station Community & \multicolumn{2}{|c|}{0} & 0 & 0 \\
\hline & & Main Street Community & \multicolumn{2}{|c|}{$\begin{array}{l}0 \\
0\end{array}$} & 0 & 0 \\
\hline & & Boulevard Community & \multirow{2}{*}{\multicolumn{2}{|c|}{$\begin{array}{l}0 \\
1\end{array}$}} & 0 & 0 \\
\hline & & \begin{tabular}{|l|} 
Employment/ Job Center \\
\end{tabular} & & & 1 & 1 \\
\hline & & \begin{tabular}{|l|} 
Transit Station Village \\
\end{tabular} & \multicolumn{2}{|c|}{0} & 0 & 0 \\
\hline & & Growth Center & \multicolumn{2}{|c|}{0} & 0 & 0 \\
\hline & & $\begin{array}{l}\text { Transit Oriented Development } \\
\text { (TOD) }\end{array}$ & \multicolumn{2}{|c|}{0} & 0 & 3 \\
\hline & \multirow{4}{*}{$\begin{array}{c}\text { Plan \& } \\
\text { Program Terms } \\
\end{array}$} & Wasatch Choice for 2040 & \multicolumn{2}{|c|}{0} & 0 & 0 \\
\hline & & \begin{tabular}{|l|} 
Envision Utah \\
\end{tabular} & \multicolumn{2}{|c|}{0} & 0 & 1 \\
\hline & & TRAX & \multicolumn{2}{|c|}{0} & 0 & 2 \\
\hline & & FrontRunner & \multicolumn{2}{|c|}{0} & 0 & 2 \\
\hline & \multirow{2}{*}{ Agency Terms } & $\begin{array}{l}\text { Wasatch Front Regional Council } \\
\text { (WFRC) }\end{array}$ & \multicolumn{2}{|c|}{0} & 0 & 0 \\
\hline & & $\begin{array}{l}\text { Mountainland Association of } \\
\text { Governments }\end{array}$ & & 0 & 0 & 1 \\
\hline
\end{tabular}


Figure 6-6: Plan Evaluation Summary-Salt Lake City (Continued)

\begin{tabular}{|c|c|c|c|c|c|}
\hline Jurisdiction & Category & Search Term & $\begin{array}{c}\text { Generation 1: } \\
\text { Approx 1985-1998 }\end{array}$ & $\begin{array}{c}\text { Generation 2: Approx } \\
\text { 1999-2009 } \\
\end{array}$ & $\begin{array}{c}\text { Generation 3: Approx } \\
\text { 2010-2015 } \\
\end{array}$ \\
\hline & & & 1993 General Plan & 2003 General Plan & No Plan \\
\hline \multirow{16}{*}{ Murray } & \multirow{10}{*}{$\begin{array}{l}\text { Urban Center } \\
\text { Related Terms }\end{array}$} & Metropolitan Center & 0 & 0 & \\
\hline & & Urban Center & 0 & 0 & \\
\hline & & Town Center & 0 & 1 & \\
\hline & & Station Community & 0 & 0 & \\
\hline & & Main Street Community & 0 & 0 & \\
\hline & & Boulevard Community & 0 & 0 & \\
\hline & & \begin{tabular}{|l} 
Employment/ Job Center \\
\end{tabular} & 1 & 0 & \\
\hline & & Transit Station Village & 0 & 0 & \\
\hline & & Growth Center & 0 & 0 & \\
\hline & & $\begin{array}{l}\text { Transit Oriented Development } \\
\text { (TOD) }\end{array}$ & 1 & 2 & \\
\hline & \multirow{4}{*}{$\begin{array}{c}\text { Plan \& } \\
\text { Program Terms }\end{array}$} & Wasatch Choice for 2040 & 0 & 0 & \\
\hline & & \begin{tabular}{|l|} 
Envision Utah \\
\end{tabular} & 0 & 0 & \\
\hline & & TRAX & 0 & 2 & \\
\hline & & FrontRunner & 0 & 0 & \\
\hline & \multirow{2}{*}{ Agency Terms } & $\begin{array}{l}\text { Wasatch Front Regional Council } \\
\text { (WFRC) }\end{array}$ & 0 & 1 & \\
\hline & & $\begin{array}{l}\text { Mountainland Association of } \\
\text { Governments }\end{array}$ & 0 & 0 & \\
\hline & & & 1997 General Plan & 2009 General Plan & 2014 General Plan \\
\hline \multirow{16}{*}{$\begin{array}{c}\text { Pleasant } \\
\text { View }\end{array}$} & \multirow{10}{*}{$\begin{array}{l}\text { Urban Center } \\
\text { Related Terms }\end{array}$} & Metropolitan Center & 0 & 0 & 0 \\
\hline & & Urban Center & 0 & 0 & 0 \\
\hline & & Town Center & 0 & 0 & 0 \\
\hline & & Station Community & 0 & 0 & 0 \\
\hline & & Main Street Community & 0 & 0 & 0 \\
\hline & & Boulevard Community & 0 & 0 & 0 \\
\hline & & Employment/ Job Center & 0 & 0 & 1 \\
\hline & & \begin{tabular}{|l} 
Transit Station Village \\
\end{tabular} & 0 & 0 & 0 \\
\hline & & Growth Center & 0 & 0 & 0 \\
\hline & & $\begin{array}{l}\text { Transit Oriented Development } \\
\text { (TOD) }\end{array}$ & 0 & 1 & 1 \\
\hline & \multirow{4}{*}{$\begin{array}{c}\text { Plan \& } \\
\text { Program Terms }\end{array}$} & Wasatch Choice for 2040 & 0 & 0 & 0 \\
\hline & & Envision Utah & 0 & 0 & 0 \\
\hline & & \begin{tabular}{|l} 
TRAX \\
\end{tabular} & 0 & 0 & 0 \\
\hline & & FrontRunner & 0 & 1 & 2 \\
\hline & \multirow{2}{*}{ Agency Terms } & $\begin{array}{l}\text { Wasatch Front Regional Council } \\
\text { (WFRC) }\end{array}$ & 1 & 0 & 1 \\
\hline & & $\begin{array}{l}\text { Mountainland Association of } \\
\text { Governments }\end{array}$ & 0 & 0 & 0 \\
\hline
\end{tabular}


Figure 6-6: Plan Evaluation Summary-Salt Lake City (Continued)

\begin{tabular}{|c|c|c|c|c|c|}
\hline Jurisdiction & Category & Search Term & $\begin{array}{c}\text { Generation 1: } \\
\text { Approx 1985-1998 }\end{array}$ & $\begin{array}{c}\text { Generation 2: Approx } \\
\text { 1999-2009 } \\
\end{array}$ & $\begin{array}{c}\text { Generation 3: Approx } \\
\text { 2010-2015 }\end{array}$ \\
\hline & & & 1998 General Plan & 2003 General Plan & 2010 General Plan \\
\hline \multirow{17}{*}{$\begin{array}{l}\text { South } \\
\text { Jordan }\end{array}$} & \multirow{10}{*}{$\begin{array}{l}\text { Urban Center } \\
\text { Related Terms }\end{array}$} & Metropolitan Center & 0 & 0 & 0 \\
\hline & & Urban Center & 0 & 0 & 0 \\
\hline & & Town Center & 0 & 1 & 2 \\
\hline & & \begin{tabular}{|l} 
Station Community \\
\end{tabular} & 0 & 0 & 0 \\
\hline & & Main Street Community & 0 & 0 & 0 \\
\hline & & Boulevard Community & 0 & 0 & 0 \\
\hline & & Employment/ Job Center & 1 & 1 & 1 \\
\hline & & \begin{tabular}{|l} 
Transit Station Village \\
\end{tabular} & 0 & 0 & 0 \\
\hline & & \begin{tabular}{|l|} 
Growth Center \\
\end{tabular} & 0 & 0 & 0 \\
\hline & & $\begin{array}{l}\text { Transit Oriented Development } \\
\text { (TOD) }\end{array}$ & 0 & 1 & 2 \\
\hline & \multirow{4}{*}{$\begin{array}{c}\text { Plan \& } \\
\text { Program Terms }\end{array}$} & Wasatch Choice for 2040 & 0 & 0 & 0 \\
\hline & & Envision Utah & 0 & 0 & 0 \\
\hline & & TRAX & 0 & 0 & 1 \\
\hline & & FrontRunner & 0 & 0 & 1 \\
\hline & \multirow{2}{*}{ Agency Terms } & $\begin{array}{l}\text { Wasatch Front Regional Council } \\
\text { (WFRC) }\end{array}$ & 0 & 0 & 0 \\
\hline & & $\begin{array}{l}\text { Mountainland Association of } \\
\text { Governments }\end{array}$ & 0 & 0 & 0 \\
\hline & & & No Plan & 2003 General Plan & No Plan \\
\hline \multirow{16}{*}{ Sandy } & \multirow{10}{*}{$\begin{array}{c}\text { Urban Center } \\
\text { Related Terms }\end{array}$} & Metropolitan Center & & \multirow{6}{*}{$\begin{array}{l}0 \\
0 \\
0 \\
0 \\
0 \\
0\end{array}$} & \\
\hline & & \begin{tabular}{|l} 
Urban Center \\
\end{tabular} & & & \\
\hline & & \begin{tabular}{|l} 
Town Center \\
\end{tabular} & & & \\
\hline & & Station Community & & & \\
\hline & & Main Street Community & & & \\
\hline & & Boulevard Community & & & \\
\hline & & Employment/ Job Center & & 1 & \\
\hline & & Transit Station Village & & \multirow{2}{*}{$\begin{array}{l}0 \\
0\end{array}$} & \\
\hline & & \begin{tabular}{|l|} 
Growth Center \\
\end{tabular} & & & \\
\hline & & \begin{tabular}{|l|}
$\begin{array}{l}\text { Transit Oriented Development } \\
\text { (TOD) }\end{array}$ \\
\end{tabular} & & 0 & \\
\hline & \multirow{4}{*}{$\begin{array}{c}\text { Plan \& } \\
\text { Program Terms }\end{array}$} & Wasatch Choice for 2040 & & 0 & \\
\hline & & Envision Utah & & 0 & \\
\hline & & TRAX & & 0 & \\
\hline & & FrontRunner & & 0 & \\
\hline & \multirow{2}{*}{ Agency Terms } & $\begin{array}{l}\text { Wasatch Front Regional Council } \\
\text { (WFRC) }\end{array}$ & & 0 & \\
\hline & & $\begin{array}{l}\text { Mountainland Association of } \\
\text { Governments }\end{array}$ & & 0 & \\
\hline
\end{tabular}


Figure 6-6: Plan Evaluation Summary-Salt Lake City (Continued)

\begin{tabular}{|c|c|c|c|c|c|}
\hline Jurisdiction & Category & Search Term & $\begin{array}{c}\text { Generation 1: } \\
\text { Approx 1985-1998 }\end{array}$ & $\begin{array}{c}\text { Generation 2: Approx } \\
\text { 1999-2009 }\end{array}$ & $\begin{array}{c}\text { Generation 3: Approx } \\
\text { 2010-2015 }\end{array}$ \\
\hline & & & No Plan & 2005 General Plan & 2010 General Plan \\
\hline \multirow{16}{*}{ Clearfield } & \multirow{10}{*}{$\begin{array}{c}\text { Urban Center } \\
\text { Related Terms }\end{array}$} & Metropolitan Center & & 0 & 0 \\
\hline & & Urban Center & & 0 & 0 \\
\hline & & Town Center & & 0 & 0 \\
\hline & & Station Community & & 0 & 0 \\
\hline & & Main Street Community & & 0 & 0 \\
\hline & & Boulevard Community & & 0 & 0 \\
\hline & & Employment/ Job Center & & 0 & 0 \\
\hline & & Transit Station Village & & 0 & 0 \\
\hline & & Growth Center & & 0 & 0 \\
\hline & & $\begin{array}{l}\begin{array}{l}\text { Transit Oriented Development } \\
\text { (TOD) }\end{array} \\
\end{array}$ & & 0 & 1 \\
\hline & \multirow{4}{*}{$\begin{array}{c}\text { Plan \& } \\
\text { Program Terms }\end{array}$} & Wasatch Choice for 2040 & & 0 & 0 \\
\hline & & Envision Utah & & 0 & 0 \\
\hline & & TRAX & & 0 & 0 \\
\hline & & \begin{tabular}{|l|} 
FrontRunner \\
\end{tabular} & & 0 & 1 \\
\hline & \multirow{2}{*}{ Agency Terms } & $\begin{array}{l}\text { Wasatch Front Regional Council } \\
\text { (WFRC) }\end{array}$ & & 0 & 0 \\
\hline & & $\begin{array}{l}\text { Mountainland Association of } \\
\text { Governments }\end{array}$ & & 0 & 0 \\
\hline
\end{tabular}




\subsubsection{Change in the Nature of Centers}

Another trend in both regions has been a distinct change in the concept of centers over time. In the early generations of local comprehensive plans, centers were often a site of concentrated activity. Shopping centers, office parks, and medical complexes often appeared in plans as centers, and the comprehensive plan language tended to reflect a more simplistic view of centers.

In many of Denver's first-generation plans (1979-1996), these areas were often referred to as “employment centers” (offices) or were existing or anticipated retail centers. In plans from subsequent generations, many centers shifted from single use to multiple use, increased the emphasis on transportation accessibility and began to capture elements of well-rounded amenity centers (see Figure 6-7). Thus, areas of employment began to be mixed with multifamily housing, commercial and retail uses located near transit stations. In a few jurisdictions, this transformation has been dramatic — not just as a regional planning idea, but as a strategy for attracting new investment and capturing new market demands.

The Salt Lake City region also demonstrated a similar evolution in the center concept. In the first two periods of General Plan analysis (before 2000, and between 2000 and 2010), the majority of the mentions of "centers" dealt loosely with the concept of centers of employment. Some of the more recent General Plan updates, however, are much more nuanced in how they interpret the concept of centers. Expanded definitions of centers that arise in the most recent iteration of General Plan updates include the following terms: Urban Center, Town Center, Station Community, and Main Street Community.

The interviews with city planners from each of the case study cities also sheds additional light about how the concept of centers has developed (at least partially) as a result of the creation and adoption of the Wasatch Choice for 2040 Vision. 
Figure 6-7: Examples of Local Plan Evolution Center Concepts (Denver Region)

\begin{tabular}{|c|c|c|}
\hline Generation 1: Pre-Metro Vision & Generation 2: Post-Metro Vision & Generation 3: Latest Plan \\
\hline $\begin{array}{l}\text { Aurora (1989): } \\
\text { - No reference to metropolitan } \\
\text { centers or use of similar concepts } \\
\text { - References employment centers } \\
\text { and calls for them to be located } \\
\text { close to transportation corridors } \\
\text { and transit }\end{array}$ & $\begin{array}{l}\text { Aurora (1998): } \\
\text { - Center types identified; } \\
\text { - Policies refer to regional centers, } \\
\text { with retail a focus; recommends } \\
\text { zoning for centers; employment } \\
\text { centers still focused on office use }\end{array}$ & $\begin{array}{l}\text { Aurora (2009): } \\
\text { - More prominent use of centers } \\
\text { concepts and supporting policies; } \\
\text { - Seven policies to support location } \\
\text { and development of centers; } \\
\text { - Shift to a more multi-functional view } \\
\text { of centers (mix of uses) }\end{array}$ \\
\hline $\begin{array}{l}\text { Thornton (1985): } \\
\text { - No reference to centers } \\
\text { - Regional and neighborhood retail } \\
\text { centers identified; } \\
\text { - Multi-purpose center refers to city } \\
\text { center (government + retail) }\end{array}$ & $\begin{array}{l}\text { Thornton (1997): } \\
\text { - Identifies centers and calls for a } \\
\text { major focus on city center; } \\
\text { - Other centers focuses more on } \\
\text { single uses (shopping, } \\
\text { employment) }\end{array}$ & $\begin{array}{l}\text { Thornton (2007): } \\
\text { - Plan calls for mixed use centers at } \\
\text { RTD station areas; } \\
\text { - Several policies support mixed use, } \\
\text { including a new TOD zoning district }\end{array}$ \\
\hline $\begin{array}{l}\text { Lakewood (1987): } \\
\text { - No reference to metropolitan } \\
\text { centers or use of similar concepts } \\
\text { - Refers to employment centers, but } \\
\text { does not define them }\end{array}$ & $\begin{array}{l}\text { Lakewood (2003): } \\
\text { - Identifies TOD with two supporting } \\
\text { policies } \\
\text { - Identifies four types of centers } \\
\text { with seven supporting policies: (1) } \\
\text { Major Urban, (2) Employment, (3) } \\
\text { Community Mixed-Use, and (4) } \\
\text { Neighborhood }\end{array}$ & $\begin{array}{l}\text { Lakewood (2015): } \\
\text { - TODs become a major focus of plan } \\
\text { with many supporting policies } \\
\text { - Urban center and mixed use center } \\
\text { concepts folded into TOD terms and } \\
\text { approaches } \\
\text { - Neighborhood and Employment } \\
\text { centers largely unchanged }\end{array}$ \\
\hline $\begin{array}{l}\text { Arvada (1985) } \\
\text { - No reference to urban centers or } \\
\text { similar concepts } \\
\text { - Employment centers mentioned } \\
\text { briefly but with no implementation } \\
\text { Arvada (1995) } \\
\text { - Recommends four areas for urban } \\
\text { center designation } \\
\text { - TOD emerges; referenced once } \\
\text { - One reference to Metro Vision }\end{array}$ & & $\begin{array}{l}\text { Arvada (2005) } \\
\text { - TODs } 1 \text { goal; } 1 \text { of } 6 \text { community } \\
\text { development principles. } \\
\text { - Consistent with Metro Vision } 2020 \\
\text { - Extensive discussion of DRCOG and } \\
\text { RTD partnership/ coordination } \\
\text { Arvada (2014) } \\
\text { - Focus on TODs goal and policies } \\
\text { - Specific polices on FasTracks } \\
\text { implementation and centers } \\
\end{array}$ \\
\hline
\end{tabular}

Figure 6-8: Examples of Local Plan Evolution Center Concepts (Salt Lake City Region)

\begin{tabular}{|c|c|c|}
\hline Generation 1: 1985 - 1999 & Generation 2: $2000-2009$ & Generation 3: 2010 - 2015 \\
\hline $\begin{array}{l}\text { Salt Lake City Northwest Plan } \\
\text { (1992): } \\
\text { - Limited mention of Wasatch Front } \\
\text { Regional Council: mostly in } \\
\text { reference to light rail development } \\
\text { and transportation coordination } \\
\text { - Some discussion of "growth } \\
\text { centers" and directly high density } \\
\text { residential development to these } \\
\text { locations }\end{array}$ & $\begin{array}{l}\text { Salt Lake City - Sugar House } \\
\text { Master Plan (2001, 2005): } \\
\text { - Reference to WFRC regional } \\
\text { transportation planning and long } \\
\text { term transit planning, but not } \\
\text { mention of Wasatch Choice } \\
\text { - Extensive discussion of Town } \\
\text { Center mixed use development } \\
\text { - Notes potential for future transit } \\
\text { alignment and preferred station } \\
\text { areas }\end{array}$ & $\begin{array}{l}\text { Salt Lake City Plan (2015): } \\
\text { - No mention of Wasatch Choice } \\
\text { - Guiding principles highlight: } \\
\text { variety of housing, transportation } \\
\text { choices, access to neighborhood } \\
\text { services, and responsible growth } \\
\text { - Core set of center policies are } \\
\text { focused on Transit Oriented } \\
\text { Development (TOD) including a } \\
\text { significant TOD Initiative }\end{array}$ \\
\hline
\end{tabular}




\subsubsection{Transit-Oriented Development}

In discussing centers and related terminology, it is important to give separate treatment to the term transit-oriented development (TOD). In both regions, TOD emerged in local planning documents with increasing frequency since the late 1990s. During this same period, the Salt Lake City and Denver regions were in the midst of planning and building light rail lines.

In both regions, it is important to note that centers and TODs are not necessarily the same concept. There are centers that encompass transit stations and therefore align with the TOD concept. There are also centers without transit and are unlikely to get fixed transit stations in the future. Finally, there are areas with fixed transit stations that are not designated as centers.

\subsubsection{Denver}

In the Denver region, the most dramatic increase in the use of the term transit-oriented development took place in Denver, Lakewood, and Arvada. In Denver, the term first appeared in the 2000 comprehensive plan, and was more prominent as the city began to prepare neighborhood plans in areas where new stations were being built. The city also prepared a TOD Strategic Plan in 2006 and 2014 that included a typology, strategies, and supporting policies. Similarly, in Lakewood TOD was used lightly in its 2003 comprehensive plan, but was a major focus in the 2015 version. The 2015 plan strongly emphasized the TOD concept, included six TOD specific goals, and each goal provided a set of associated action steps. Even Thornton, which otherwise lags in the adoption of centers policy, shows increased integration of TOD discussion. For example, TOD is not mentioned in the 1997 Thornton Comprehensive Plan but emerges in the city's 2007 Comprehensive Plan along with a short list of policies, strategies and catalyst actions. In the 2012 Thornton Comprehensive Plan there are more frequent references to TODs and the language used is targeted and specific. The 2012 plan even lays out a detailed set of criteria for evaluating TOD implementation.

\subsubsection{Salt Lake City}

In the Salt Lake City region, TOD has been a focus of general plans for longer than most of the other key terms that were identified. As far back as the 1990s, several general plans incorporated the concept of TOD. The incorporation of TOD as a term and as a practical means of development has increased at a high rate over the past couple of decades. Usage of the term "transit-oriented development" increased in nearly every city between the 1990s and today (see Figure 6-8). The scores also reflect greater clarity of language, frequency of use, and visibility within the plan.

\subsection{The Driving Forces Behind Centers}

It is clear from our analysis of local plans in both the Denver and Salt Lake City regions that there is increasing adoption and support for centers within local plans. Some cities have embraced them more fully than others, some cities have invested in them more substantially than others, and some cities face more barriers to developing centers than others. 
An earlier study of the metropolitan planning in Denver found a more mixed response to the concept of Metro Vision and urban centers. Many jurisdictions did not support centers, only abided by them because of the transportation funding incentives, or supported them out of fear that stronger mandatory policies might emerge (Margerum, 2005a). Based on our interviews with planners for this study, local planners indicate that city responses have changed significantly as have the forces encouraging the adoption of centers.

Though each city planner in the Salt Lake City region provided different information about how and why each activity center developed and evolved as it did, there were a few common themes found in all (or most) of the case study cities. The primary driving factors behind "center" developments in the case study cities were: 1) private investments in areas surrounding TOD centers; 2) completion of light rail stations; 3) a desire to increase sales tax revenue by developing economic centers; and 4) city government support around the concept of center development, which is often directly opposed by public sentiment from within the community.

Table 6-9 (below) summarizes how planners in each jurisdiction rated the various driving forces behind centers. In both regions, market forces and the completion of light rail stations were rated most highly. Other factors, such as funding incentives, local planning and investment, and sale tax revenue had varied impact. Funding incentives scored highly in Likert scale questions but interviews revealed this to be a more complex question. There was a fairly consistent agreement that regional plans, regional plan concepts and a desire for multifamily housing have had the least impact. 
Figure 6-9: Factors Influencing Local Adoption of Centers (Planners' Views)

\begin{tabular}{|l|l|l|l|l|l|l|}
\hline City & $\begin{array}{l}\text { Light rail } \\
\text { investment }\end{array}$ & Sales tax & $\begin{array}{l}\text { Funding } \\
\text { Incentives }\end{array}$ & $\begin{array}{l}\text { Regional } \\
\text { Vision }\end{array}$ & $\begin{array}{l}\text { Multi-fam. } \\
\text { Housing }\end{array}$ & $\begin{array}{l}\text { Market } \\
\text { Forces }\end{array}$ \\
\hline Denver Region & & & & & & \\
\hline Arvada & 5 & 3 & 4 & 3 & 3 & 5 \\
\hline Aurora & 5 & 5 & 5 & 5 & 5 & 5 \\
\hline Centennial & 5 & 4 & 3 & 1 & 3 & 5 \\
\hline Denver & 5 & 1 & 5 & 2 & 2 & 5 \\
\hline Englewood & 5 & 5 & 5 & 4 & 4 & 5 \\
\hline $\begin{array}{l}\text { Greenwood } \\
\text { Village }\end{array}$ & 5 & 5 & 4 & 3 & 1 & \\
\hline Lakewood & $*$ & $*$ & $*$ & $*$ & $*$ & $*$ \\
\hline Lone Tree & 4 & 4 & 3 & 2 & 2 & 4 \\
\hline Thornton & 2 & 1 & 5 & 2 & 2 & 4 \\
\hline Westminster & 5 & 3 & 5 & 3 & 2 & 4 \\
\hline $\begin{array}{l}\text { Salt Lake City } \\
\text { Region }\end{array}$ & & & & & & \\
\hline Pleasant View & $*$ & $*$ & $*$ & $*$ & $*$ & $*$ \\
\hline Clearfield & $*$ & $*$ & $*$ & $*$ & $*$ & $*$ \\
\hline Murray & $*$ & $*$ & $*$ & $*$ & $*$ & $*$ \\
\hline Sandy & $*$ & $*$ & $*$ & $*$ & $*$ & $*$ \\
\hline South Jordan & $*$ & $*$ & $*$ & $*$ & $*$ & $*$ \\
\hline Lehi & $*$ & $*$ & $*$ & $*$ & $*$ & $*$ \\
\hline Salt Lake City & $*$ & $*$ & $*$ & $*$ & $*$ & $*$ \\
\hline
\end{tabular}

Scale: 1 (none); 2 (limited) 3 (moderate); 4 (strong) to 5 (very strong)

Note: * indicates response was not available

\subsubsection{Driving Force: Market Forces}

The consistent theme heard from planners in almost all jurisdictions is that market forces have been a significant factor supporting the adoption of centers. These market forces include increased demand for multifamily housing (Nelson, 2006; HUD, 2016) and an increased desire to live in locations with a mix of urban-like amenities.

Many planners noted that Millennials and Empty Nesters (parents with kids who have left home) are increasingly seeking these more urban settings. This perception is supported by recent studies. The TransitCenter commissioned an online survey of 11,842 respondents across 46 metropolitan statistical areas (MSAs) in the United States. The study found that many respondents wish they lived in mixed-use neighborhoods, towns and suburbs, rather than the residential areas they currently occupy (see Figure 6-10). In addition to this, employment instability, increasing housing prices and the experience with the last recession have all helped decrease the interest in homeownership. The result is increased demand for multifamily housing and developers are investing heavily in this market segment. 
Figures 6-10: Housing and Neighborhood Preferences

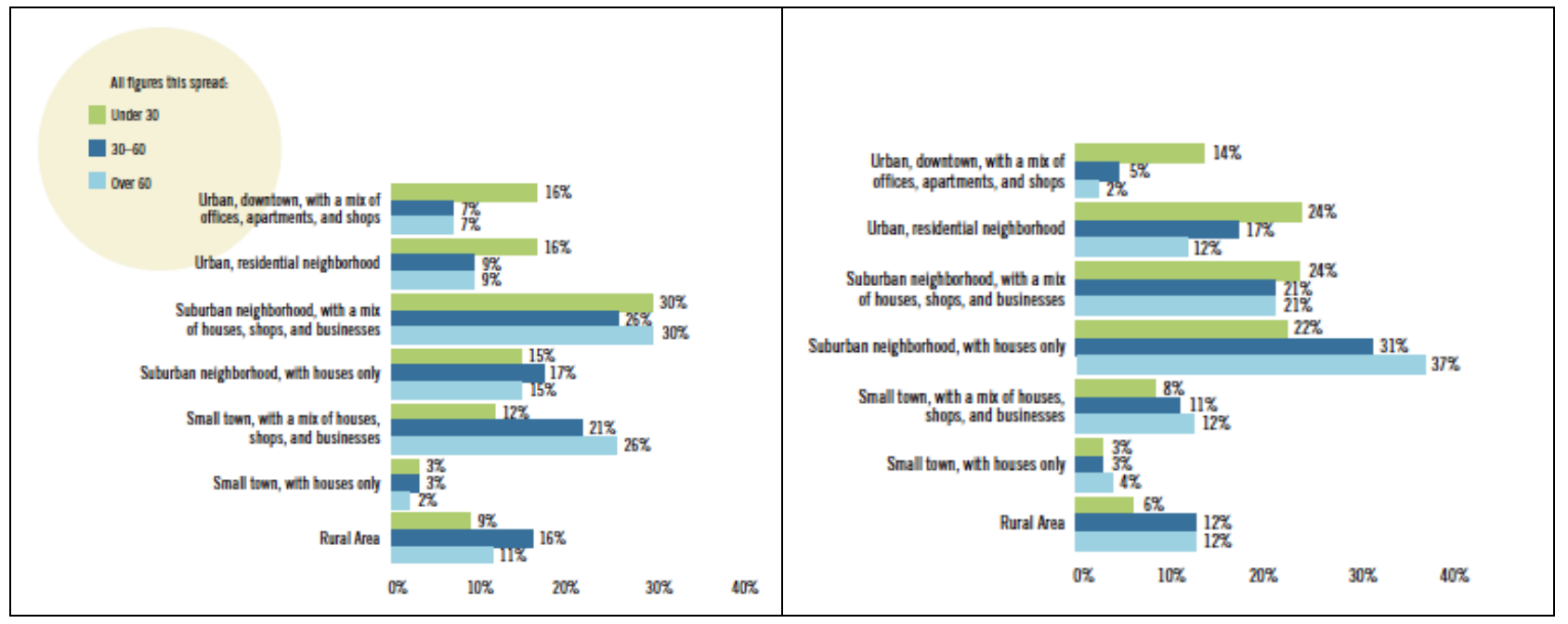

In addition to the shifting housing demand, many of these same individuals are seeking a different living environment. They would like to reduce commute times, have access to a walkable urban environment, and be located near restaurants, coffee shops and retail areas. When combined with the demand for multifamily housing, this creates the market ingredients for mixed-use urban centers. This changing demand was highlighted in media coverage in the Denver region:

"Dan Cohen is a developer for D4 Urban, which built the 275-unit complex with apartments and two-story townhomes. He said the project caters to younger professionals and others out of college who don't need to spend a lot of time at home; instead they want to take advantage of area amenities and quick access to light rail downtown at a relatively affordable price” (Illescas, 2016).

Momentum developer Jamie Temple commenting about a Lakewood development: "We see this as a great opportunity being next to a light-rail station, being adjacent to the Rocky Mountain College of Art and Design along with the revitalization of the Lamar Station Plaza and West Colfax” (Briggs, 2016).

Perhaps nowhere has this shift and shifting attitude been more evident than in Aurora, CO, and Lehi, UT. Aurora sits on the eastern edge of the Denver metropolitan area and for the past several decades development has been dominated by some of the lowest-cost, single-family detached housing. However, city officials feared that this would make the city less competitive in a changing housing market and more likely to lose future investment to other cities. As a result, they worked closely with RTD, landowners and other stakeholders to encourage alignment of the $\mathrm{R}$ line along a corridor that would increase the potential to link new stations with urban development. As a result, the stations near Civic Center and the University of Colorado hospital were located to try to capitalize on existing amenities and employment centers. To support these centers the city has made substantial investments, including new infrastructure, structured parking and last-mile bicycle and pedestrian connections. In a Denver Post article about station development, it was noted that the city was placing ads in magazines and on the radio to attract 
younger, working professionals. City spokesperson Kim Stuart noted, "The important thing is talking to people beyond Aurora, which is a new endeavor for us” (Illescas, 2016).

In the Salt Lake City region, planners indicated that the biggest driving force has been investment by private firms and organizations around designated activity centers adjacent to TRAX and FrontRunner stations. In several cities, planners were aware of large companies that decided to build offices because of their proximity to planned stations. For example, in the "point of the mountain" area that borders the city of Lehi and its TRAX transit station, Adobe, Workfront, Microsoft, MX Technologies, and Xactware have all invested in new facilities. They have collectively helped make the Wasatch Front known as "Silicon Slopes." Due to the insurgence of technology companies in the area, there have been significant amount of investments in the "center” around the Lehi FrontRunner station.

\subsubsection{Driving Force: Transit Investment and Types of Station Areas}

A second consistent theme from our interviews with planners was that transit investment has been a substantial catalyst for supporting and developing centers. Both the Salt Lake City and Denver regions have invested in light rail. In particular, the tax measure passed by voters in the Denver region is leading to over 100 stations being opened along light rail, commuter rail and bus rapid transit lines.

As with the market forces, media coverage (especially in the Denver region) has highlighted the role that transit and station has played in stimulating private investment.

"Light Rail is a game changer, creating lots of opportunities for jobs and housing," says John Cheney, vice president of land development at Oakwood Homes, Green Valley Ranch's developer. "We've seen consistent demand even with price increases" (Samuelson, 2016).

LCP Development Jonathan Bush of LCP Development commented on an Englewood site: "All of the embedded amenities are there," Bush said. "We are literally across the street from the Oxford light rail platform. Englewood Rec Center is a block away and Broken Tee Golf Course is half a mile to the west" (Rubino, 2016).

"As we look to hire lots of employees, my dream is that most of my employees will be living within walking distance. For those who do live somewhere else, I want them to be on the train," said Jim Doyle, president of Panasonic Enterprise Solutions, which is moving its headquarters to Denver this summer. "We really, really want this to be a true transit-oriented development. And if everyone is getting in a car and driving, that's a huge failure" (Chuang, 2016).

However, there are some important nuances about the role that transit investment has played. First, in some locations planners indicated that light rail access is triggering private investment. In particular, tech firms are responding to employee desires to have transportation alternatives. 
As noted above, planners in cities such as Lehi and Sandy noted that high-tech businesses were explicit in choosing to build new offices in location near TRAX stations. These stations were also typically accompanied by substantial local government investment in infrastructure, pedestrian and bike access, and other amenities. In a 2015 study of the relationship between economic development and transit in the Salt Lake region, researchers asked local planners and staff at state and local economic development agencies to identify companies that had made recent location decisions based on proximity to rail transit stations. Interviewees identified 17 such companies, including notable high-tech firms such as eBay, Adobe, Overstock.com, and Workday that had all recently located in the Lehi and Draper areas of south Salt Lake County/north Utah County (Economic Development Research Group, 2015).

Second, in some locations new stations are the trigger for a range of public investments to create mixed-use amenity centers that will, in turn, attract private investment. In particular, these amenity centers are desired by those that want more urban living or who want offices located next to walkable urban-like environments. For example, planners from the cities of Aurora and Centennial, CO, both noted that their councils were concerned that their cities were only providing suburban and auto-oriented community environments, and they would be missing out on future investment that was focusing more on amenity centers.

Not all planners we interviewed were convinced that the stations themselves were the key catalyst. They speculated that public investment in items such as infrastructure, improved pedestrian and bike access, structured parking and other amenities could-by itself-induce some of the same private investment. The new transit stations were the initial action that triggered other substantial public commitments. In other words, some speculated that the same kind of substantial public investment without a transit station might also attract private investment.

Finally, not all centers are created equal and based on our review of plans, interviews with planners, and analysis of spatial data, we have identified a typology of three different center types: tipping point centers, re-urbanization centers and greenfield centers.

\subsubsection{Tipping Point Centers}

Tipping point centers already contain several critical elements necessary to create an active, multiuse center. These may include historic town centers or existing concentrations of higherdensity employment or housing. The light rail, station and public investment could be viewed as a tipping point that leads to a transformation of these centers into a mixed-use, amenity center. As noted above, it is not always clear whether it is the station itself or the intensity of public and private investment that provides this tipping point.

In Colorado, Arvada's historic Olde Town struggled for many years as a largely suburban and car-oriented development pattern that dominated the city's landscape. Community leaders, however, have long sought to take advantage of the area's strong urban form and historic buildings to reinvigorate the area as an amenity-rich, traditional downtown. The approval of FasTracks and decision to locate a station adjacent to Olde Town has triggered a new wave of development, including several significant higher-density housing projects on vacant or industrial land located near the station (see Figure 6-11). 
Figure 6-11: Development in Arvada’s Olde Town Neighborhood

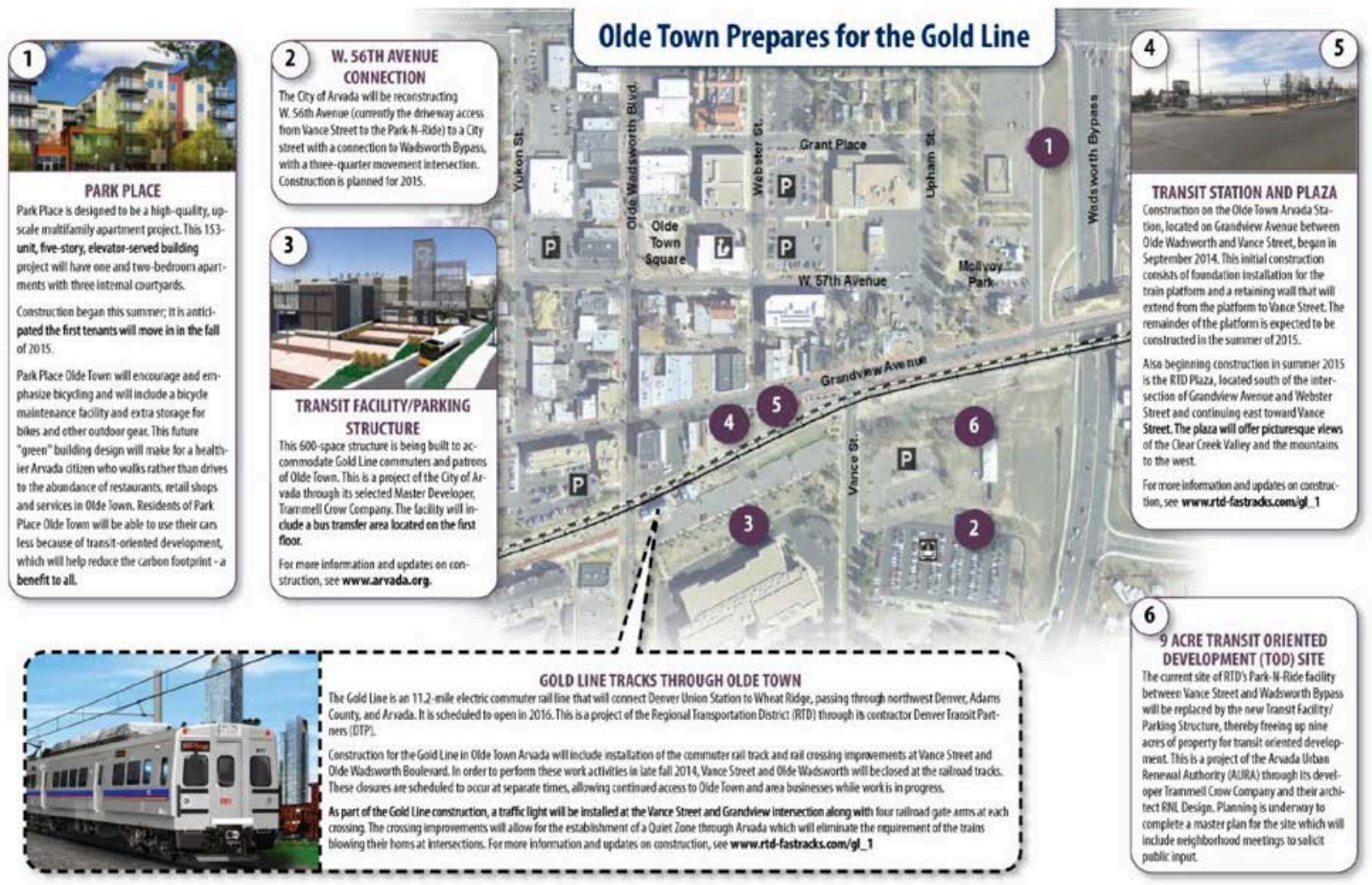

Source: City of Arvada, CO

In Salt Lake's Sugar House neighborhood (a "Town Center” in the Wasatch Choice Vision), the re-introduction of streetcar service after a 70-year hiatus, has helped to catalyze an economic development boom that has resulted in private development investments totaling more than $\$ 400$ million. This reinvestment in the neighborhood has netted a total of more than 390,000 square feet of new retail space, 300,000 square feet of new office space, and 1,058 new housing units (see Figure 6-12). 
Figure 6-12: Development in the Salt Lake City Sugar House Neighborhood
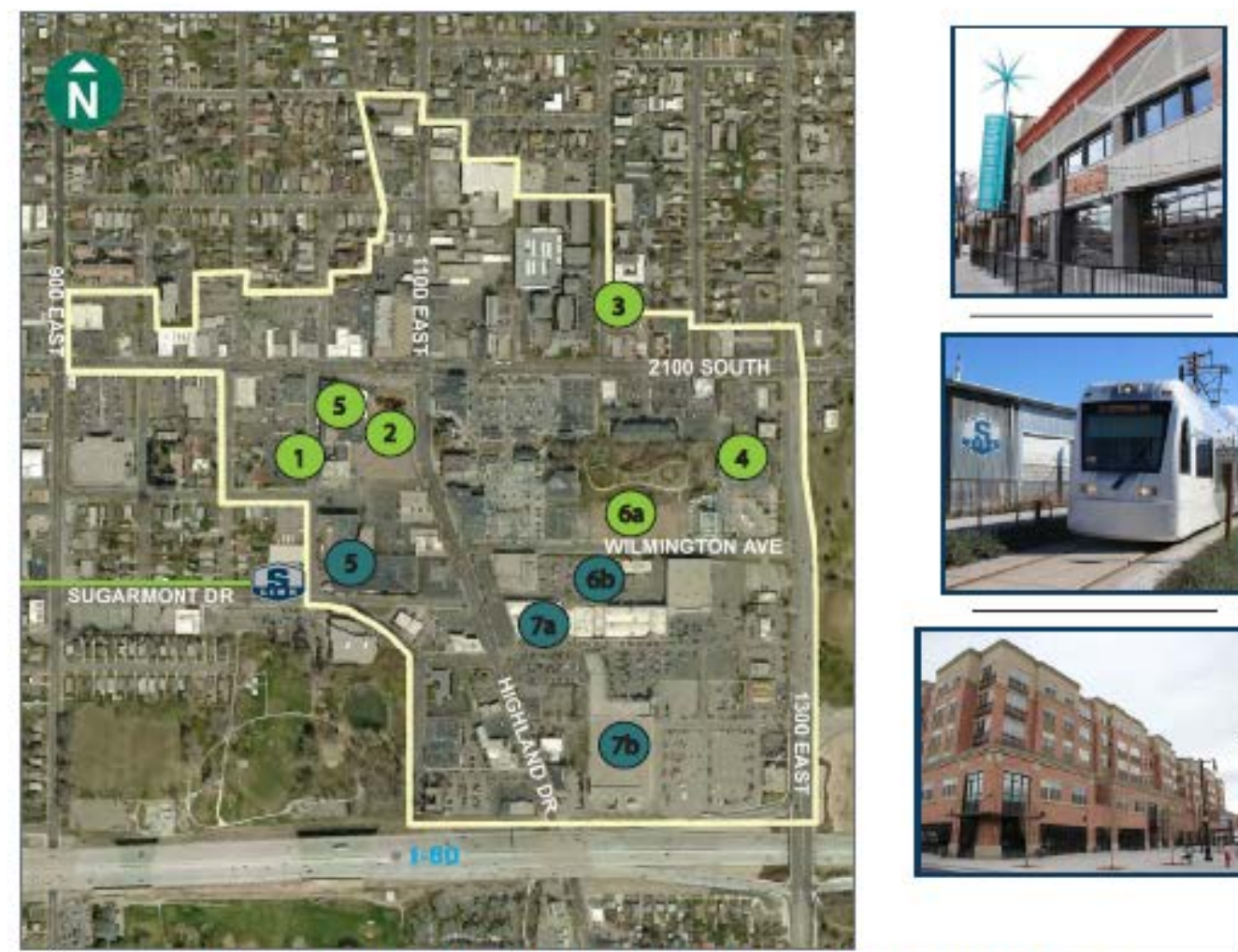

\begin{tabular}{|c|c|c|c|c|c|c|c|}
\hline \multicolumn{8}{|c|}{ TOD Complete, Underway, or Planned within 0.5 Miles of the S-Line } \\
\hline \multirow{2}{*}{ Project } & \multirow{2}{*}{ Address } & \multirow{2}{*}{\begin{tabular}{|l|} 
Res. \\
Units \\
\end{tabular}} & \multicolumn{4}{|c|}{\begin{tabular}{|l|} 
Square Footage \\
\end{tabular}} & \multirow{2}{*}{$\begin{array}{c}\text { Private } \\
\text { Investment }\end{array}$} \\
\hline & & & Res. & Retail & Office & TOTAL & \\
\hline Liberty Village & 2150 S. McClelland & 171 & 134,000 & 1.200 & - & 135,200 & $\$ 23$ million \\
\hline SHCrossing & 2130 S. 1100 East & 211 & 207,000 & 56,000 & - & 263,000 & $\$ 53$ million \\
\hline Sugar House Apts. & 1985 S. 1200 East & 70 & 70,000 & - & - & 70,000 & $\$ 11$ million \\
\hline Westminster & 2162 S. 1300 East & 44 & 67,000 & 8.500 & 15,000 & 90,500 & $\$ 28$ million \\
\hline Granite Furniture & 1050 E. 2100 South & - & - & 20,000 & 30,000 & 50,000 & $\$ 50$ million \\
\hline Wilmington I North & 1201 E. Wilmington & 112 & 100,000 & 50,000 & 30,000 & 180,000 & $\$ 35$ million \\
\hline \multicolumn{2}{|c|}{ COMPLETE OR UNDERWAY TOTAL } & 608 & 578,000 & 135,700 & 75,000 & 788,700 & $\$ 200$ million \\
\hline Wilmington I South & $1201 \mathrm{E}$. Wilmington & 100 & 100,000 & 10,000 & - & 110,000 & $\$ 35$ million \\
\hline SH Center West & Simpson \& Highland & 250 & 200,000 & 95,000 & 80,000 & 375,000 & $\$ 85$ million \\
\hline SH Center East & Simpson \& Highland & 100 & 300,000 & 150,000 & 150,000 & 600,000 & $\$ 85$ million \\
\hline \multicolumn{2}{|l|}{ PLANNED TOTAL } & 450 & 600,000 & 255,000 & 230,000 & $1,085,000$ & $\$ 205$ million \\
\hline
\end{tabular}

Source: Salt Lake City

\subsubsection{Re-urbanization Centers}

Re-urbanization centers are those with an existing suburban or industrial development pattern located in largely auto-oriented areas. As a result, of this land use pattern, these areas will require substantial public and private investment for a station site to transition to a mixed-use, amenity center. These centers have the highest likelihood of never developing beyond simply stations or a park and ride. 
There are several significant constraints on redeveloping these centers. First, many of the light rail lines in Denver and Salt Lake City were aligned along existing rail lines. Land use along many of these lines is often designated for industrial development. The transformation from industrial to mixed use or even higher-density housing or office space is a significant challenge, and many of these centers may never be developed beyond its station functions. For example, Aurora's planners noted that the Peoria station area faced significant land use challenges that would make it a difficult area to redevelop (see Figure 6-13).

Several light rail lines in the Denver area extend through low-density suburbs with centers located near shopping centers and strip retail. These areas have potential for redevelopment because they are already commercially oriented, but large tracts of land can be difficult for developers to assemble and there is considerable risk in investing in higher-density development in a low-density area. These centers are further complicated when major freeways or roadways restrict mobility and access to transit stops or station.

In some locations, the city has been a catalyst for this re-urbanization. For example, the city of Westminster purchased a 100-acre site that was formerly a regional shopping mall. They lobbied RTD to include a bus rapid transit station adjacent to the site and are spending more than $\$ 70$ million to prepare the infrastructure, open space and amenities to create a new downtown district. Other government and non-government organizations have also played a role. In Aurora, the city worked with RTD to move the light rail line off its freeway alignment and into the center of a new downtown district. Newspaper coverage highlights the efforts the city put into supporting redevelopment around the station. Aurora transportation planner Mac Callison noted, "We wanted to integrate it into the fabric of the city - employment, service centers and residential areas of the city." Aurora Mayor Hogan commented, "It's going to make this part of Aurora really an urban center, part of the overall transition of Aurora from a suburb to a city" (Illescas, 2015).

In the Salt Lake region, the same streetcar line that is catalyzing reinvestment in Sugar House is, at the other end of the line, providing an armature for the re-urbanization of an area once dominated by small-scale industrial and warehouse uses and more recently the location of vacated buildings, empty lots where buildings once stood, and a lot of chain-link fences. This is “downtown” South Salt Lake City (a "Station Community” in the Wasatch Choice Vision), and it is now the location of a rapid re-urbanization process, but with different types and forms than once occupied the area. The city has adopted new master plans and form-based zoning for two areas along the streetcar. The first, a 50-acre residential neighborhood called the East Streetcar District, anticipates up to 1,500 new housing units, plus neighborhood retail, services and offices along the streetcar line. The second, 280-acre Downtown South Salt Lake area anticipates 2,500 housing units, 1 million square feet of retail, and 3 million square feet of office space in the next 25 years. This translates to 20,000 new jobs and 7,000 new residents (in a city with 25,000 residents currently). Pursuant to these planning initiatives, construction is currently underway for two large residential projects in the East Streetcar district with 600 housing units. 
Figure 6-13: Peoria Station-Aurora, CO

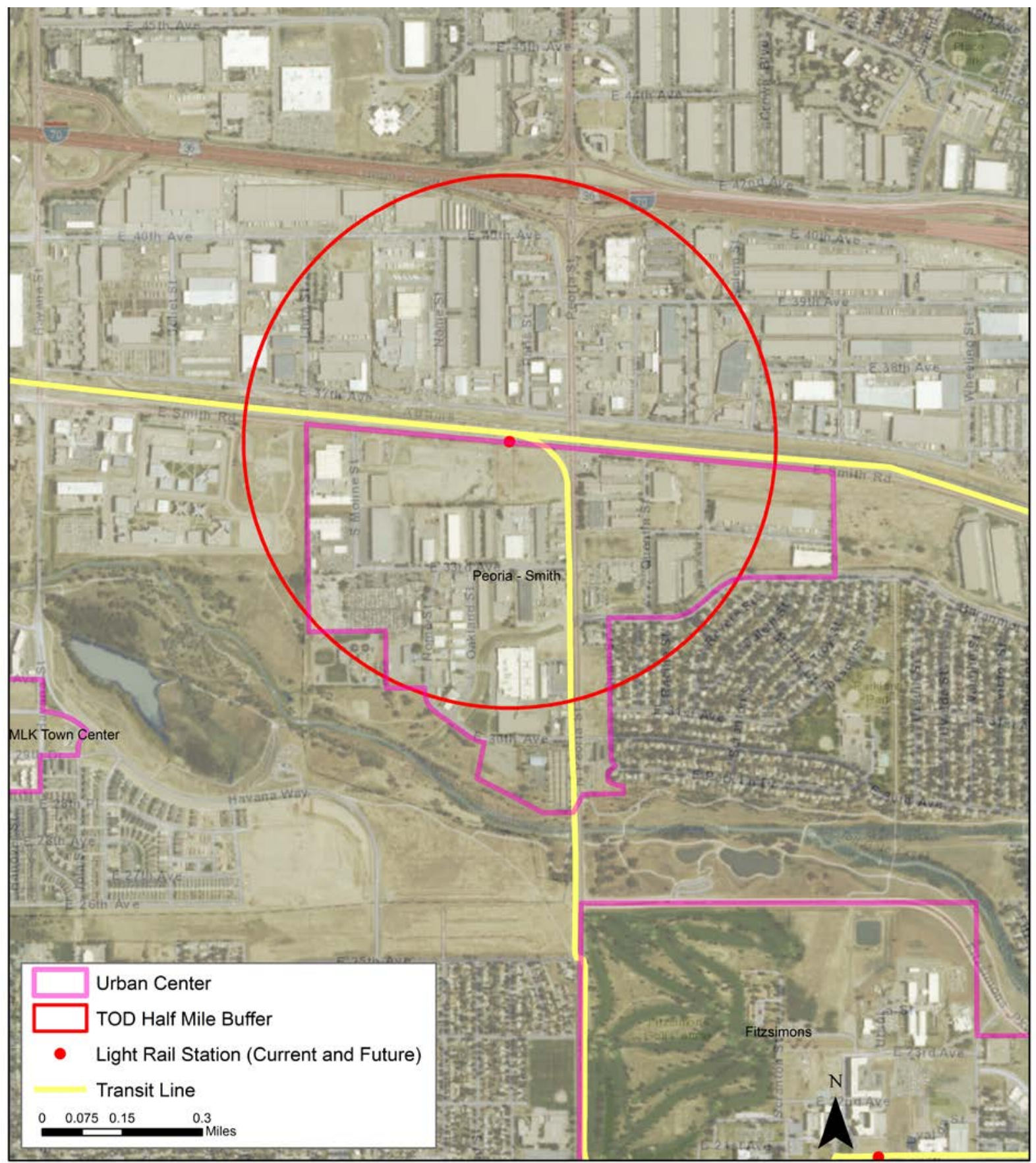

\subsubsection{Greenfield Centers}

Centers in some outlying communities are designated in sites that contain significant "greenfield" areas within the designated center, meaning that it contains large undeveloped acreage. While these also require substantial public and private investment, they do not face the same kind of challenges of transformation faced by re-urbanization centers. However, many of these sites are located at the urban fringe, where many planners indicated there is less 
development interest. Furthermore, because these sites are largely vacant, developers are reluctant to undertake small projects unless there is already momentum to develop. Greenfield sites also require significant public investment, and for communities with several stations this may be a lower priority unless there is significant development interest.

For example, the land near the proposed Eastlake rail station in the Thornton, CO, contains a considerable amount of undeveloped land. The city engaged in a master-planning process to redevelop the vacant areas, and is proposing a new urban center of moderate-density housing and some retail surrounded by new single-family residential. The plan is not a dramatic change from the low-density development that currently exists within the city, but proposes a higher-density and mix of uses to attract young professionals. The plan also proposes significant investment in infrastructure, bike, pedestrian and open space amenities, and efforts to create community assets around an historic grain elevator (City of Thornton, 2015). 
Figure 6-14: Eastlake at $124^{\text {th }}$ Ave Station -Thornton, CO

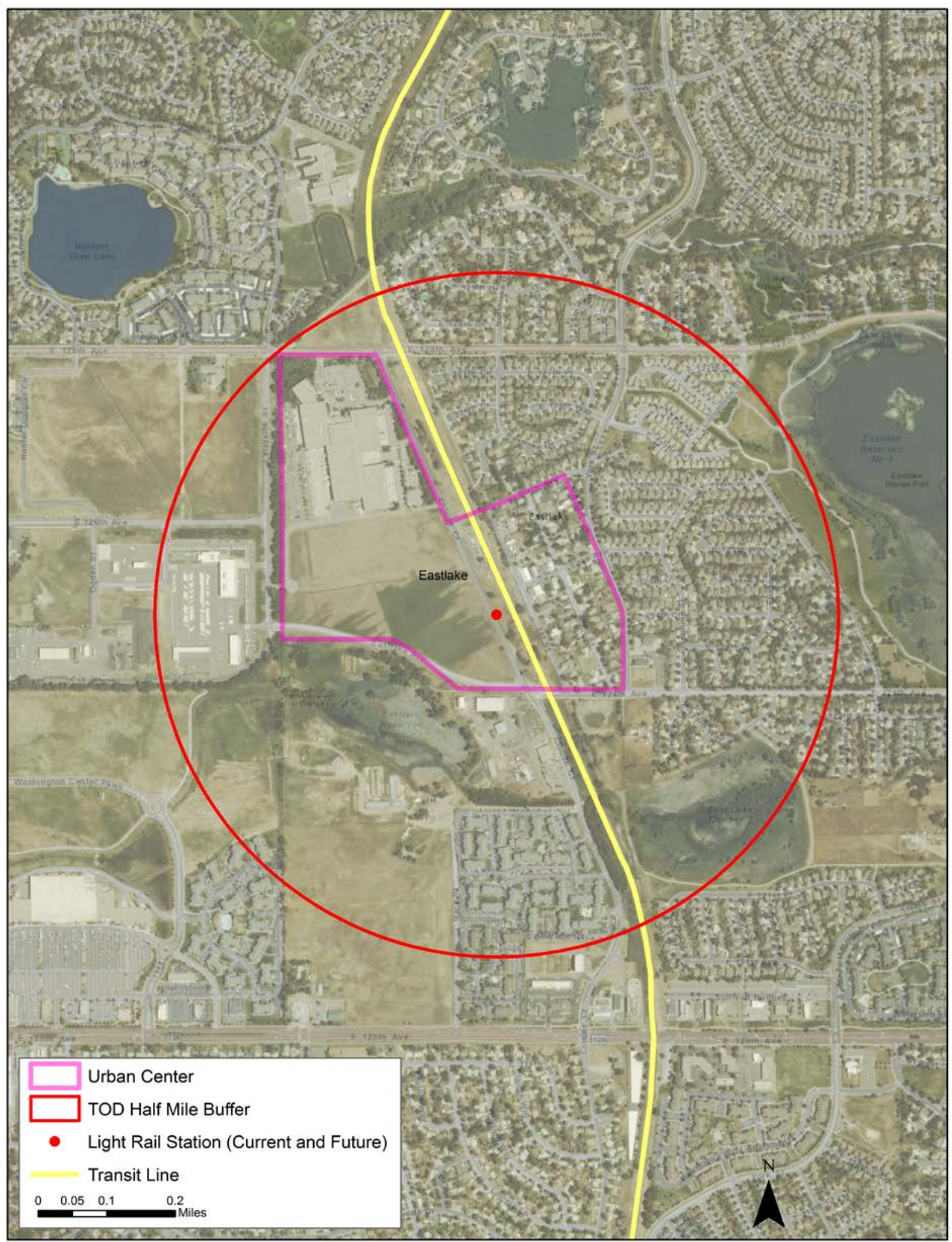


A more ambitious greenfield center is RidgeGate City Center - a designated urban center located in Lone Tree, $\mathrm{CO}$ - which includes two future light rail stations on the Southeast Rail Line extension (Lone Tree City Center and RidgeGate Parkway). Largely undeveloped, RidgeGate City Center is located in close proximity to another DRCOG designated urban center RidgeGate West Village. RidgeGate West Village is anchored by the Sky Ridge Medical Center which be served by light rail service beginning in 2019. The aptly named Lone Tree City Center station will serve as the focal point for Lone Tree's future with plans to include high-density development and an active mixture of uses. The 2008 Lone Tree Comprehensive Plan designates the area around the station for transit-oriented development (Lone Tree, 2008). 
Figure 6-15: RidgeGate City Center -Lone Tree, CO

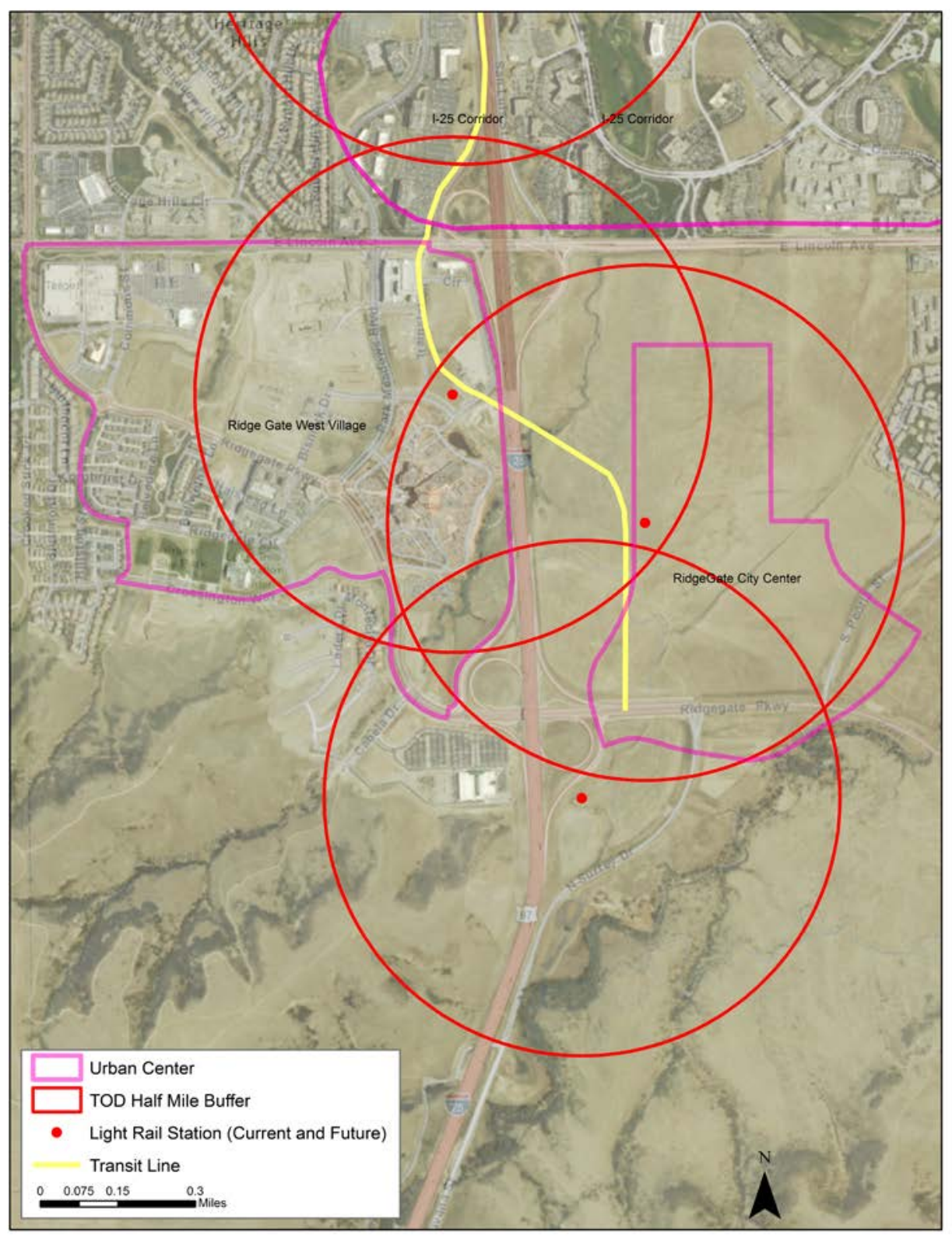

\subsubsection{Driving Force: Planning and Local Investment}

In a few jurisdictions, local planners have asserted that planning has been the driving force behind centers. In these jurisdictions, the development of centers has faced significant barriers, including lack of supporting infrastructure, existing development and market forces that make higher-density development more difficult to develop.

Several case study communities are making substantial local-level investments by creating urban renewal districts in transit station and urban center areas. By doing this, local government can utilize tax increment financing to invest in infrastructure improvements further. In some cases, cities have taken the lead in the redevelopment process. Westminster purchased a 100-acre site 
that was formerly a regional shopping center, demolished the center and is now taking the lead in a new high-density, mixed-use development.

Several cities have also amended their planning codes to support different development patterns. The city of Aurora has established transit-oriented development (TOD) zoning to incentivize vertical mixed-use development in designated centers. Areas with TOD zoning allow for increased density, loosening of height restrictions, and reductions in minimum parking requirements. Aurora is also investing last-mile connections around RTD stations using an \$8 million budget for betterments including pedestrian bridges, sidewalks, and bicycle infrastructure.

However, in most jurisdictions planners placed this factor farther down the list, and indicted that planning was reacting more to factors such as market demand and transit investment-rather than being a leading factor.

\subsubsection{Driving Force: Sales Tax}

Another factor noted in some studies of metropolitan development was that local option sales tax revenue created an incentive for developing centers, because it would attract more commercial development. Due to property tax limitations and other fiscal pressures, many cities have been increasingly relying on sales tax for local government infrastructure and services.

In the Denver region, planners provided mixed responses when asked about the role sales tax revenue plays in the development or designation of centers, indicating that the importance of this factor varies considerably by jurisdiction. In the case of Englewood, the Cinderella Mall (once the largest shopping center west of the Mississippi) closed in 1997 and the loss of sales tax revenue had a significant impact on the city budget. For Greenwood Village, the city's low property tax rate means that sales tax revenue is the main driver of the city's budget. For both communities, attracting new retail is therefore an important strategy.

In contrast, cities such as Denver, Thornton, Arvada and Westminster have a significant amount of existing high-volume retail centers. Therefore, the additional revenue gained through center redevelopment is not as significant a factor. The goal of retail in many of these areas is to create an amenity center to support multifamily housing or employment centers.

In the Salt Lake City region, most of the planners indicated that there was pressure from constituents, city officials, or tight budgets to increase the number of sources and amount of revenue collected from commercial establishments, especially those around more densely developed centers.

\subsubsection{Driving Force: Grants and Funding Incentives}

In the U.S., Metropolitan Planning Organizations (MPOs) are responsible for preparing regional transportation plans and allocating federal funding through a Transportation Improvement 
Program (TIP). In both metropolitan regions, the MPOs have utilized the criteria for selecting transportation projects as an incentive for adopting principles in the regional vision plans.

In the Denver metropolitan area, implementation of the regional Metro Vision plan has been supported by incentives built into the TIP funding allocation process. Under Metro Vision 2020, up to $20 \%$ of the TIP funding criteria were designated to local government compliance with Metro Vision plan and its urban growth boundaries (Margerum, 2005b). This process has been amended several times, and the TIP allocation under the Metro Vision 2035 plan included both qualitative assessment and scoring bonuses for projects that met conditions such as: developing an urban center or town center, increasing population density, and jurisdiction is a signatory to the Mile High Compact. The changes in the regional TIP policy related specifically to centers is summarized below in Table 6-17. Data from DRCOG also highlights that many of the funded TIP projects received points under the urban center funding criteria (see Table 6-18).

Table 6-16: Denver Area TIP Policy Criteria Related to Centers

\begin{tabular}{|c|c|c|}
\hline $\begin{array}{l}\text { TIP } \\
\text { Cycle }\end{array}$ & Project Criteria Points Related to Centers & Definitions and Characteristics \\
\hline $\begin{array}{l}2008- \\
2013\end{array}$ & $\begin{array}{l}\text { - } 6 \text { points: serving Denver Central Business District (CBD) } \\
\text { - } 5 \text { points: serving fixed guideway transit station } \\
\text { - } 3 \text { points: serving other urban center } \\
\text { - } 0 \text { points: not serving an urban center } \\
14 \text { Points Total ( } 14 \% \text { of total possible points) }\end{array}$ & $\begin{array}{l}\text { - Project directly serving (touching) } \\
\text { or indirectly linked } \\
\text { - Proximity varies by mode type } \\
\text { (ped, bike, bus, roadway) }\end{array}$ \\
\hline $\begin{array}{l}2012- \\
2017\end{array}$ & $\begin{array}{l}\text { - } 6 \text { points: urban center within } 1 / 4 \text { mile of a rapid transit station } \\
\text { - } 5 \text { points: urban center served by transit with } \leq 15 \text { min headways } \\
\text { - } 4 \text { points: urban center served by transit with } \leq 30 \text { min headways } \\
\text { - } 2 \text { points: All other urban centers or rapid transit station that is } \\
\text { not an urban center } \\
\text { - } 0 \text { points: not in proximity to urban center or rapid transit station } \\
17 \text { Points Total ( } 17 \% \text { of total possible points) }\end{array}$ & $\begin{array}{l}\text { - Rapid transit station= stations } \\
\text { identified in constrainted Metro } \\
\text { Vision RTP } \\
\text { - Serving=physically touching } \\
\text { - Proximity varies by mode type } \\
\text { (ped, bike, bus, roadway) }\end{array}$ \\
\hline $\begin{array}{l}2016- \\
2021\end{array}$ & $\begin{array}{l}\text { - } 5 \text { points: within .25 miles of an urban center or rural town center } \\
\text { - } 5 \text { points: if project demonstrates three of the following- } \\
\text { o Located within an urban center or rural town center served } \\
\text { by transit } \leq 30 \text { min combined peak service headways } \\
\text { o Located in urban or rural town center where community } \\
\text { has implemented mixed use zoning or development plans } \\
\text { o Located in urban or rural town center where community } \\
\text { has adopted parking management strategies. } \\
\text { o Located in urban or rural town center with community } \\
\text { commitment to preserve or develop affordable housing } \\
\text { O Proposed project is identified in an adopted Urban Center } \\
\text { Master Plan or Station Area Master Plan. } \\
10 \text { Points Total (10\% of total possible points) }\end{array}$ & $\begin{array}{l}\text { - Centers defined in adopted Metro } \\
\text { Vision } 2035 \\
\text { - Parking management strategies } \\
\text { must minimize negative effects on } \\
\text { urban center development and } \\
\text { multimodal access } \\
\text { - Affordable housing defined by } \\
\text { households earning 0-60\% of AMI } \\
\text { and/or for-sale units for households } \\
\text { earning } 0-80 \% \text { of AMI }\end{array}$ \\
\hline
\end{tabular}

Source: Denver Regional Council of Governments, 2016 
Table 6-17: Denver Area Allocation of Funding in Relation to Urban Center (UC) Criteria

\begin{tabular}{|c|c|c|c|c|c|c|c|}
\hline & \multicolumn{2}{|c|}{ Projects Submitted } & \multicolumn{2}{c|}{ Projects Selected } & \multicolumn{3}{c|}{ Funding Allocation } \\
\hline TIP Cycle & $\begin{array}{c}\text { Total \# } \\
\text { submitted }\end{array}$ & $\begin{array}{c}\text { Total \# } \\
\text { receiving } \\
\text { UC points }\end{array}$ & $\begin{array}{c}\text { Total \# } \\
\text { submitted }\end{array}$ & $\begin{array}{c}\text { Total \# } \\
\text { receiving } \\
\text { UC points }\end{array}$ & $\begin{array}{c}\text { Total } \\
\text { Allocated } \\
\text { 000's }\end{array}$ & $\begin{array}{c}\text { Allocated to } \\
\text { UC projects } \\
\text { '000s }\end{array}$ & $\begin{array}{c}\text { Percent to } \\
\text { UC projects }\end{array}$ \\
\hline $2008-2013$ & 74 & 50 & 51 & 41 & $\$ 99,287$ & $\$ 78,082$ & $78.64 \%$ \\
\hline $2012-2017$ & 115 & 83 & 28 & 26 & $\$ 87,489$ & $\$ 81,144$ & $92.75 \%$ \\
\hline $2016-2021$ & 135 & 66 & 47 & 33 & $\$ 174,822$ & $\$ 135,817$ & $77.69 \%$ \\
\hline
\end{tabular}

UC = Urban Center

Allocated Funding = total funding for project; not just direct urban center expenditures

Source: Denver Regional Council of Governments, 2016

In addition to the TIP funding criteria, DRCOG has grant programs that help cities plan for developing station areas and urban centers. In its first four years, funding was limited only to station-area master planning. In 2011, the DRCOG Board of Directors expanded the program to include urban centers and committed additional funding. Since 2007, DRCOG has provided over $\$ 6.3$ million in funding to support 43 station-area master planning studies (Source: Urban Center/Station Area Master Planning Grant Program background summary prepared by DRCOG staff, April 2016).

A survey of individuals involved in regional transportation and land use decision making in the Denver region asked them to evaluate its effect on land use decisions across the region. The survey found a mixed response to the impact of the regional plans $(n=39)$ :

- $36 \%$ of respondents said it very insignificant or insignificant

- $38 \%$ said it was neither significant or insignificant

- $26 \%$ indicated it was significant or very significant (Margerum, Brody, Parker and McEwen, 2011).

In our interviews with planners for this study, most indicated that grant funding was a relatively low motivating factor in terms of its influence on local planning or elected officials' decisions about adopting centers. Other factors were more important for leading cities to adopt the centers concept and to create a truly mixed-use center. However, once adopted grants for station-area planning were important for many cities to speed up the implementation of planning and development work.

In the Salt Lake City region, the 2015-2040 Regional Transportation Plan incorporated criteria that rewarded projects that served centers identified in Wasatch Choice. This was the first time that this has been included in the TIP policy criteria, and it is too soon to determine the impact this has had on local government support for centers. 
Table 6-18: Salt Lake City Area TIP Policy Criteria Related to Centers

\begin{tabular}{|c|c|c|}
\hline $\begin{array}{l}\text { TIP } \\
\text { Cycle }\end{array}$ & Project Criteria Points Related to Centers & Definitions and Characteristics \\
\hline $\begin{array}{l}2011- \\
2040\end{array}$ & No points allocated specifically to centers & \\
\hline $\begin{array}{l}2015- \\
2040\end{array}$ & $\begin{array}{l}\text { - } 5 \text { points: connections to Wasatch Choice centers } \\
\text { - } 5 \text { points: Access or connections to infill areas } \\
\text { and/or redevelopment areas } \\
10 \text { Points Total ( } 10 \% \text { of total possible points) }\end{array}$ & $\begin{array}{l}\text { - Five points to project within } 3 / 4 \text { mile to a Wasatch } \\
\text { Choice } 2040 \text { center, } \\
\text { - Five points to projects within three-quarter mile } \\
\text { of an infill or redevelopment area }\end{array}$ \\
\hline
\end{tabular}

Source: Wasatch Front Regional Council, 2016

\subsubsection{Driving Force: Regional Centers Concept and Policies}

There are very mixed findings about the extent to which regional-level discussion and policies about centers have been a factor influencing local plans. Based on our plan analysis, it is clear in both metropolitan regions that the concept of centers has gradually been adopted into local government plans. In the first generation of plans (pre-regional plan adoption) most jurisdictions do not include concepts related to centers, and centers that are identified tend to be single dimensional. In the second generation (after the first set of regional planning efforts), local jurisdictions continued identifying centers and increasingly defined them as having a mixture of uses. The third generation only exists in the Denver metropolitan region, and is characterized by updated regional policies and funding incentives as well as local plans with in-depth discussion of centers including specific policies and supporting language.

These findings highlight that local plans in both regions have evolved over time to more fully incorporate the concept of centers. Regional planning in Salt Lake City has consistently been at least one planning cycle behind regional planning in Denver, yet Utah cities are demonstrating a similar pattern of local plan evolution. This may suggest that regional planning efforts are having a gradual influence on these concepts.

In the Denver region, many planners cited the Metro Vision plans as having a relatively minor impact on local plans. Several factors may explain this assessment. First, several planners noted that centers are not assigned by the Denver Regional Council of Governments (DRCOG), but they are designated in joint effort between DRCOG and the local jurisdiction. Thus, as one planner noted, "We were not being asked to designate areas as centers that we did not already identify-but the objectives and standards for those centers were often negotiated.” This suggests that the impact for many current planners may relate more to how centers are developed and how they perform relative to regional goals around housing, employment and vehicle miles travelled. Second, many of the areas designated as centers have long been noted in local government plans for higher intensity activity. For example, the 1979 Comprehensive Plan for the City of Arvada noted five potential locations for future transit stations along existing rail lines. Three of these stations will be opening in 2016. Third, it is clear from our plan analysis that centers have been incorporated into many local plans for over 10 years. Therefore, planners may attribute little impact from the regional plan because the concept has now become engrained in local plans. The planners that we interviewed were fairly uniform in rating this as having the least influence on current planning. 
In the Salt Lake City region, a few planners mentioned the Wasatch Choice for 2040 Vision as being an aid to the creation of their respective general plans, but only to a limited degree. For the most part it only had an influence when it aligned with the local vision, and the existing views of the public and city officials. There are at least three significant reasons for this limited impact. First, discussion about the 2040 Vision Map and Principles did not begin until about 2005 and were not finalized until 2010. Thus, these documents were not in place when many of the local plans were being prepared. Second, the 2040 document is a vision, map and some very general principles. Therefore, there are few policies, programs or clear criteria to reference in the regional document. Finally, even more so than the Denver regional planning, there is a very strong theme of local control over land use planning. Regional plan documents include statements about local control in their land use objectives, and the other objectives simply encourage local governments to coordinate decision-making and consider the impact that land use and transportation decisions have on each other.

\subsection{Public and Political Response: Support and Opposition}

Denver interviews revealed that there is public and political support for centers policy in the majority of case study communities. Political support has largely evolved around the desire to capture investment and development trends that favor mixed-use, amenity-based projects. Public support tends to vary by the particular aspects of the center, with centers located near existing single-family housing experiencing the most community concerns.

In Aurora, political support is buoyed by a desire to infuse more high-income housing and commercial development into the community. The city of Denver has also seen general political support for centers. Planning staff in Lone Tree indicated that while the average citizen is not familiar with the centers concept outlined in Metro Vision, they are supportive of the city's local growth plans, which emphasize regional growth principles. Westminster has set a vision of becoming the north Denver region's new regional center, and the city council has made a major commitment to this vision by purchasing and redeveloping an abandoned mall adjacent to one of the planned light rail stations.

Greenwood Village, more so than other case study communities, follows two distinctly different development patterns. While the majority of the community is made up of low-density, singlefamily housing, the I-25 corridor (which includes the Southeast Rail Line and parts of the Denver Tech Center) has high employment density and more intense development. Planning staff credited the Denver Tech Center's history as a regional employment center as a leading contributor to community support for centers development. Outside the Tech Center, concerns over building height, obstructed views and parking have come up with Greenwood Village residents. Similar trends have been observed in Centennial, Westminster and Englewood. Many of the new developments are emerging in areas that have already been commercial or industrial, which has generally not led to significant community opposition. However, as the number of new developments increase and it begins to encroach on nearby single-family neighborhoods, there has been increased concerns about development impacts.

In Thornton, political interest in centers only extends to receiving TIP funding. Beyond that, public and political leaders are generally resistant towards the push for increased density within 
the community. This stems from concerns that increased density will change the suburban character of the community. Senior planning staff cited the emergence of an anti-transit group rallying against the construction of the North Metro Rail Line as an example. The anti-transit group raised concerns over increased crime around planned transit stations. 


\subsection{FINDINGS: SPATIAL ANALYSIS}

To examine the impact of regional centers policy we sought to assess the changes in demographics, land use and transportation in Denver and Salt Lake City centers. The indicators used for this analysis were based on those identified by the two planning agencies.

\section{Figure 7-1: Indicator Description}

\begin{tabular}{|l|l|l|}
\hline Category & Indicator & Description \\
\hline Demographics & Population & $\begin{array}{l}\text { Change in population of the station area from } 2000 \text { to } \\
2010\end{array}$ \\
\cline { 2 - 3 } & \multirow{5}{*}{ Jobs } & $\begin{array}{l}\text { Change in number of jobs of the station area from } \\
2002-2009\end{array}$ \\
\cline { 2 - 3 } & Household Income & $\begin{array}{l}\text { Change in average household income from } 2000 \text { to } \\
2008-2012\end{array}$ \\
\cline { 2 - 3 } & Housing Units & Change in number of housing units from 2000 to 2010 \\
\hline \multirow{5}{*}{ Land Use } & Land Use Mix & $\begin{array}{l}\text { Number of parcels and acreage of each land use } \\
\text { classification (2014) }\end{array}$ \\
\cline { 2 - 3 } & Vacancy Rate & Change in number of vacant units from 2000 to 2010 \\
\cline { 2 - 3 } & Renter v. Owner Occupancy & $\begin{array}{l}\text { Change in share renter and owner occupied from 2000 } \\
\text { to 2010 }\end{array}$ \\
\cline { 2 - 3 } & Value & Total value of parcels within the station area (2014) \\
\cline { 2 - 3 } & Year Built & Average year of development for station area (2014) \\
\hline Transportation & Cul-de-sacs & - Number of cul-de-sacs within Center (2015) \\
\hline & Cul-de-sac Ratio & Ratio of cul-de-sacs to acreage of Center (2015) \\
\hline & Street Length & Total length of streets within Center (2014) \\
\hline & Average Block Length & Average length of blocks within Center (2014) \\
\hline & Bus Stops & Number of bus stops within Center (2014) \\
\hline & Bus Routes & Number of bus routes that transect Center(2014) \\
\hline & Public Transit Use & $\begin{array}{l}\text { Percent of residents that use public transit for } \\
\text { commuting purposes (2000 to 2008-2012) }\end{array}$ \\
\hline & Households with Zero or One Car & $\begin{array}{l}\text { Percentage of households with one car or less (2000 } \\
\text { to 2008-2012) }\end{array}$ \\
\hline & Alternative Transportation Mode Share & $\begin{array}{l}\text { Percent of residents that use alternative transportation } \\
\text { for commuting purposes (2000 to 2008-2012) }\end{array}$ \\
\hline & &
\end{tabular}

Italicized data represent indicators for which researchers could not find adequate, consistent data at the appropriate level of analysis. There are many challenges with using this data, including:

- Lack of available data

- $\quad$ Lack of data at the scale of centers

- A lag time between center designation and private investment

- The effects of the Great Recession on many of the indicators

- The timing of development activities during transformation, such as the tear down of existing structures as part of higher density redevelopment

In the following sections, we discuss the findings for each metropolitan area. This is followed by a summary discussion of themes across both regions. 


\subsection{Denver Findings}

The tables below present three categories of data for Denver, conveying regional, city-level, and center-level information for case study cities. We describe trends in levels and change over time below, and compare urban centers to the trends within the city and region.

\subsubsection{Demographic: Population, Land Area and Density}

As shown in Figure 7.1, overall population in the region increased by over 18\%. Of this $18 \%$ increase in population, $53 \%$ of the growth went to our case study cities. In fact, $22 \%$ of the population growth went into the city of Denver. Most cities saw an increase in population as well, including Lone Tree, Thornton, Aurora, Arvada, Greenwood Village and Westminster. The increase in population ranged from 5\% in Westminster to $110 \%$ in Lone Tree.

Many of these cities also increased in land area through annexation. The most stark increases were in Lone Tree (455\%) and Thornton (30\%.) The land-locked cities of Westminster, Englewood and Denver did not expand in area, and Lakewood and Greenwood Village only saw modest (2-3\%) increases in area. Englewood and Lakewood both declined in population between 2000 and 2010.

Population density increased in Aurora, Denver, Greenwood Village and Thornton, with gains ranging from $8 \%$ in Denver and Aurora to 24\% in Greenwood Village. Density decreased in Arvada, Englewood and Lone Tree at rates ranging from 3\% in Arvada to 62\% in Lone Tree, where land area increased four times as fast as population.

In examining urban centers, population gains varied considerably across urban centers. Because center area remains static, the changes in density are consistent with change in population and we only report density here. It is interesting to compare population gains by rail line and to cities within which the centers are located. With the exception of Colorado Station Urban Center in Denver, all of the centers located on the Southeast line increased in population, ranging from a 3\% increase in Parker (in Aurora) to a 650\% increase in Lincoln (in Lone Tree.) Both stations on the Central line (Alameda and Broadway) declined in population, as well as both stations on the West line, which did not open in 2014. The only station in Thornton, Eastlake, will not open until 2018, but was a greenfield site in 2000 and experienced a significant population increase between 2000 to 2010 .

The trends within cities are interesting. In Aurora, the city increased in population by $18 \%$ and both centers increased in population, but gains at the center level were somewhat small in terms of total numbers, although the Hampden Center increased by 20\%. In Lone Tree and Thornton, both the city and urban centers increased in population. In both of these centers (Eastlake and Lincoln) population was sparse in 2000, so the gains were large in percentage change. The I-25 Urban Center, which is very large in area at 9.27 square miles, significantly increased in population between 2000 to 2010.

In Denver, the results were mixed. While the city population increased by $8 \%$, two of the selected centers (Belleview and Southmoor) increased and three decreased (Alameda, Broadway 
and Colorado Station.) In Lakewood, the population in the city and both centers (Oak Street and Wadsworth) declined in population. The centers declined at a greater rate than the city at $35 \%$ in Oak Street and 7\% in Wadsworth. Relative density in 2010 varies considerably across centers, from a low of 931 persons per square mile in Hampden to a high of 5,334 persons per square mile in Wadsworth. 
Figure 7-2: Denver Land Area, Population and Density for Region, Cities and Select Centers, 2000-2010

\begin{tabular}{|c|c|c|c|c|c|c|c|c|c|c|}
\hline \multirow[t]{2}{*}{ Area } & \multirow[t]{2}{*}{$\begin{array}{l}\text { Transit Line \& } \\
\text { Opening Date }\end{array}$} & \multicolumn{3}{|c|}{ Area (Square Miles) } & \multicolumn{3}{|c|}{ Population } & \multicolumn{3}{|c|}{$\begin{array}{l}\text { Density (Population Per } \\
\text { Square Mile) }\end{array}$} \\
\hline & & 2000 & 2010 & $\begin{array}{l}\% \\
\text { Change }\end{array}$ & 2000 & 2010 & $\begin{array}{l}\% \\
\text { Change }\end{array}$ & 2000 & 2010 & $\begin{array}{l}\% \\
\text { Change }\end{array}$ \\
\hline \multicolumn{2}{|c|}{$\begin{array}{l}\text { DRCOG Region (Adams, Arapahoe, Boulder, Clear Creek, } \\
\text { Denver, Douglas, Gilpin, Jefferson, Weld Counties ) }\end{array}$} & 9,041 & 9,015 & $0 \%$ & $2,595,585$ & $3,051,582$ & $18 \%$ & 287 & 339 & $18 \%$ \\
\hline Arvada & & 33 & 35 & $8 \%$ & 102,153 & 106,433 & $4 \%$ & 3,128 & 3,029 & $-3 \%$ \\
\hline Aurora & & 143 & 155 & $9 \%$ & 276,393 & 325,078 & $18 \%$ & 1,940 & 2,101 & $8 \%$ \\
\hline Hampden Town Center & Southeast - 2006 & 0.16 & 0.16 & $0 \%$ & 127 & 152 & $20 \%$ & 777 & 931 & $20 \%$ \\
\hline I-225/Parker Road & Southeast - 2006 & 0.33 & 0.33 & $0 \%$ & 2,186 & 2,246 & $3 \%$ & 6,683 & 6,865 & $3 \%$ \\
\hline Centennial & & & 29 & $\mathrm{~N} / \mathrm{A}$ & & 100,377 & N/A & & 3,495 & $\mathrm{~N} / \mathrm{A}$ \\
\hline Denver & & 153 & 153 & $0 \%$ & 554,636 & 600,158 & $8 \%$ & 3,617 & 3,923 & $8 \%$ \\
\hline Alameda Station & Central - 1994 & 0.31 & 0.31 & $0 \%$ & 559 & 468 & $-16 \%$ & 1,781 & 1,494 & $-16 \%$ \\
\hline Belleview Station & Southeast - 2006 & 0.12 & 0.12 & $0 \%$ & 329 & 581 & $77 \%$ & 2,809 & 4,964 & $77 \%$ \\
\hline Broadway Station & Central - 1994 & 0.23 & 0.23 & $0 \%$ & 559 & 511 & $-9 \%$ & 2,462 & 2,250 & $-9 \%$ \\
\hline Colorado Station & Southeast - 2006 & 0.27 & 0.27 & $0 \%$ & 1,430 & 1,343 & $-6 \%$ & 5,338 & 5,012 & $-6 \%$ \\
\hline Southmoor Park TOD & Southeast - 2006 & 0.08 & 0.08 & $0 \%$ & 258 & 315 & $22 \%$ & 3,279 & 4,011 & $22 \%$ \\
\hline Englewood & & 7 & 7 & $0 \%$ & 31,727 & 30,255 & $-5 \%$ & 4,842 & 4,614 & $-5 \%$ \\
\hline Greenwood Village & & 8 & 8 & $2 \%$ & 11,035 & 13,925 & $26 \%$ & 1,361 & 1,684 & $24 \%$ \\
\hline Lakewood & & 42 & 43 & $3 \%$ & 144,126 & 142,980 & $-1 \%$ & 3,465 & 3,334 & $-4 \%$ \\
\hline Oak Street & West - 2014 & 0.45 & 0.45 & $0 \%$ & 1,450 & 943 & $-35 \%$ & 3,229 & 2,100 & $-35 \%$ \\
\hline Wadsworth Boulevard & West - 2014 & 0.46 & 0.46 & $0 \%$ & 2,632 & 2,449 & $-7 \%$ & 5,733 & 5,334 & $-7 \%$ \\
\hline Lone Tree & & 2 & 10 & $455 \%$ & 4,873 & 10,218 & $110 \%$ & 2,827 & 1,067 & $-62 \%$ \\
\hline Lincoln Station & Southeast - 2006 & 0.10 & 0.10 & $0 \%$ & 41 & 306 & $650 \%$ & 426 & 3,196 & $650 \%$ \\
\hline Thornton & & 27 & 35 & $30 \%$ & 82,384 & 118,772 & $44 \%$ & 3,067 & 3,409 & $11 \%$ \\
\hline Eastlake Urbacn Center & North Metro -2018 & 0.16 & 0.16 & $0 \%$ & 81 & 247 & $204 \%$ & 525 & 1,593 & $204 \%$ \\
\hline Westminster & & 32 & 32 & $0 \%$ & 100,940 & 106,114 & $5 \%$ & 3,204 & 3,363 & $5 \%$ \\
\hline $\begin{array}{c}\text { I25 Corridor (Centennial, Greenwood } \\
\text { Village, Denver, Lone Tree) }\end{array}$ & Southeast - 2006 & 9.27 & 9.27 & $0 \%$ & 2,932 & 17,172 & $486 \%$ & 316 & 1,853 & $486 \%$ \\
\hline
\end{tabular}




\subsubsection{Demographic: Housing Units}

The number of housing units reflects the change in the urban fabric. While trends are somewhat consistent with population, differences exist because of changing household size and vacancy rates. Housing units are shown in Figure 7-3.

In the region, the total number of housing units increased by $22 \%$. At the city level, the total number of housing units increased in all cities. Gains ranged from 5\% in Lakewood to $122 \%$ in Lone Tree. The number of housing units increased faster than population in all cities, which could reflect the housing boom in the 2000s or smaller household sizes.

At the center level, the trends were mixed. Along the Southeast line, all centers increased in housing units, ranging from 3\% in Parker in Aurora to 829\% in Lincoln Urban Center. Even I-25 Center increased by 629\%, growing from approximately 1,500 units to nearly 11,000 units by 2010. The only center we considered on the planned North Metro line (Eastlake) grew in housing units. Along the Central Line and West Line, all centers decreased in the number of housing units. This could capture demolition for construction in the case of the West Line, and transition to new units by 2014 along the central line.

Within cities, the center trends generally reflected the same trends as population. Aurora and the centers within increased in housing units, but the gains were smaller than total city gains. In Lone Tree and Thornton, both the cities and centers increased in housing units, but the rate within centers was higher than the city. Interestingly, though Lakewood increased in housing units at the city level, both centers decreased in housing units. This could reflect demolition for construction of the light rail line which opened in 2014. In Denver, the results were mixed with a decline in units along the Central line and an increase in all centers on the Southeast line. 
Figure 7-3: Denver Housing Units for Region, Cities and Select Centers, 2000-2010

\begin{tabular}{|c|c|c|c|c|}
\hline \multirow[t]{2}{*}{ Area } & \multirow{2}{*}{$\begin{array}{l}\text { Transit Line \& } \\
\text { Opening Date }\end{array}$} & \multicolumn{3}{|c|}{ Housing Units } \\
\hline & & 2000 & 2010 & $\%$ Change \\
\hline $\begin{array}{l}\text { DRCOG Region (Adams, Arapahoe, } \\
\text { Boulder, Clear Creek, Denver, Douglas, } \\
\text { Gilpin, Jefferson, Weld Counties ) }\end{array}$ & & $1,050,836$ & $1,279,303$ & $22 \%$ \\
\hline Arvada & & 39,733 & 44,427 & $12 \%$ \\
\hline Aurora & & 109,260 & 131,040 & $20 \%$ \\
\hline Hampden Town Center & Southeast - 2006 & 67 & 80 & $19 \%$ \\
\hline I-225/Parker Road & Southeast - 2006 & 1,212 & 1,246 & $3 \%$ \\
\hline Centennial & & & 38,779 & N/A \\
\hline Denver & & 251,435 & 285,797 & $14 \%$ \\
\hline Alameda Station & Central - 1994 & 323 & 291 & $-10 \%$ \\
\hline Belleview Station & Southeast - 2006 & 240 & 524 & $119 \%$ \\
\hline Broadway Station & Central - 1994 & 315 & 306 & $-3 \%$ \\
\hline Colorado Station & Southeast - 2006 & 711 & 717 & $1 \%$ \\
\hline Southmoor Park TOD & Southeast - 2006 & 111 & 149 & $34 \%$ \\
\hline Englewood & & 14,916 & 15,478 & $4 \%$ \\
\hline Greenwood Village & & 4,206 & 6,301 & $50 \%$ \\
\hline Lakewood & & 62,422 & 65,758 & $5 \%$ \\
\hline Oak Street & West - 2014 & 737 & 518 & $-30 \%$ \\
\hline Wadsworth Boulevard & West - 2014 & 1,299 & 1,263 & $-3 \%$ \\
\hline Lone Tree & & 1,906 & 4,226 & $122 \%$ \\
\hline Lincoln Station & Southeast - 2006 & 17 & 170 & $892 \%$ \\
\hline Thornton & & 29,573 & 43,230 & $46 \%$ \\
\hline Eastlake & North Metro -2018 & 58 & 129 & $124 \%$ \\
\hline Westminster & & 39,318 & 43,968 & $12 \%$ \\
\hline $\begin{array}{l}125 \text { Corridor (Centennial, Greenwood } \\
\text { Village, Denver, Lone Tree) }\end{array}$ & Southeast - 2006 & 1,471 & 10,730 & $629 \%$ \\
\hline
\end{tabular}

\subsubsection{Demographic: Household Income.}

Before discussing trends in household income, it is important to note the recession's impacts on income. Income by region, city and center is shown in Figure 7-4. While 2000 was the height of the technology bubble, 2008-2012 was the bottom of the Great Recession. All values are reported in 2012 dollars. The declines in household income could relate to inflation values or job loss. It is difficult to disentangle. Additionally, it is difficult to comprehend whether losses resulted because of a shift in housing type (single-family to multifamily) or because of losses for existing families. As a result, we focus on relative values rather than percent change. 
Household income declined at the regional level by $11 \%$. Household income in all cities declined by 10 to $29 \%$, with the smallest declines in Denver (10\%) and Thornton (12\%). The largest decline was Greenwood Village at 29\%.

At the center level, all centers declined in household income with the exception of Alameda and Broadway Station in Denver on the Central line, where income increased by $5 \%$ and $3 \%$, respectively. It is possible that these two centers gentrified. Thus, all centers on Southeast, West and North Metro declined in income and all centers in Aurora, Lakewood, Lone Tree and Thornton declined in household income. The losses were most significant in Lone Tree (56\%) and Southmoor (47\%). 
Figure 7-4: Denver Household Income for Region, Cities and Select Centers, 2000-20082012

\begin{tabular}{|c|c|c|c|c|c|c|}
\hline \multirow[t]{2}{*}{ Area } & \multirow{2}{*}{$\begin{array}{l}\text { Transit Line \& } \\
\text { Opening Date }\end{array}$} & \multicolumn{5}{|c|}{ Household Income (2012 \$) } \\
\hline & & & 2000 & & 2008-2012 & $\begin{array}{c}\% \\
\text { Change }\end{array}$ \\
\hline $\begin{array}{l}\text { DRCOG Region (Adams, Arapahoe, Boulde } \\
\text { Clear Creek, Denver, Douglas, Gilpin, } \\
\text { Jefferson, Weld Counties) }\end{array}$ & & $\$$ & 71,003 & $\$$ & 63,238 & $-11 \%$ \\
\hline Arvada & & $\$$ & 76,536 & $\$$ & 68,017 & $-11 \%$ \\
\hline Aurora & & $\$$ & 64,087 & $\$$ & 51,048 & $-20 \%$ \\
\hline Hampden Town Center & Southeast - 2006 & $\$$ & 64,676 & $\$$ & 38,990 & $-40 \%$ \\
\hline I-225/Parker Road & Southeast - 2006 & $\$$ & 60,405 & $\$$ & 42,909 & $-29 \%$ \\
\hline Centennial & & & & $\$$ & 89,902 & $\mathrm{~N} / \mathrm{A}$ \\
\hline Denver & & $\$$ & 54,432 & $\$$ & 49,091 & $-10 \%$ \\
\hline Alameda Station & Central - 1994 & $\$$ & 41,226 & $\$$ & 43,330 & $5 \%$ \\
\hline Belleview Station & Southeast - 2006 & $\$$ & 71,357 & $\$$ & 47,677 & $-33 \%$ \\
\hline Broadway Station & Central - 1994 & $\$$ & 60,688 & $\$$ & 62,348 & $3 \%$ \\
\hline Colorado Station & Southeast - 2006 & $\$$ & 49,005 & $\$$ & 34,963 & $-29 \%$ \\
\hline Southmoor Park TOD & Southeast - 2006 & $\$$ & 120,533 & $\$$ & 63,942 & $-47 \%$ \\
\hline Englewood & & $\$$ & 53,664 & $\$$ & 44,400 & $-17 \%$ \\
\hline Greenwood Village & & $\$$ & 160,052 & $\$$ & 113,596 & $-29 \%$ \\
\hline Lakewood & & $\$$ & 66,295 & $\$$ & 55,093 & $-17 \%$ \\
\hline Oak Street & West - 2014 & $\$$ & 58,099 & $\$$ & 47,868 & $-18 \%$ \\
\hline Wadsworth Boulevard & West - 2014 & $\$$ & 43,419 & $\$$ & 26,709 & $-38 \%$ \\
\hline Lone Tree & & $\$$ & 132,714 & $\$$ & 100,659 & $-24 \%$ \\
\hline Lincoln Station & Southeast - 2006 & $\$$ & 151,838 & $\$$ & 67,348 & $-56 \%$ \\
\hline Thornton & & $\$$ & 75,026 & $\$$ & 66,176 & $-12 \%$ \\
\hline Eastlake & North Metro -2018 & $\$$ & 46,093 & $\$$ & 39,063 & $-15 \%$ \\
\hline Westminster & & $\$$ & 77,614 & $\$$ & 64,712 & $-17 \%$ \\
\hline $\begin{array}{l}\text { I25 Corridor (Centennial, Greenwood Village, } \\
\text { Denver, Lone Tree) }\end{array}$ & Southeast - 2006 & $\$$ & 96,689 & $\$$ & 58,131 & $-40 \%$ \\
\hline
\end{tabular}




\subsubsection{Land Use: Vacancy}

This section considers vacancy rates, as shown in Figure 7-6. Trends in vacancy rates may also reflect recession impacts that may have resulted in a glut of housing. Vacancy rates increased at the regional scale by two percentage points and increased in all cities by between two and four percentage points. Within the centers, more variation existed though nearly all centers saw increases in vacancy rates. Only Lincoln (Lone Tree) and Eastlake (Thornton) saw declines in vacancy rates at $10 \%$ and $19 \%$ points, respectively. Within other cities, the increases in vacancy rates ranged from 1\% in Alameda (Denver) to 9\% in Belleview (Denver.) It is important to note the high degree of variation in vacancy rates across centers. While rates in Southmoor were 2$3 \%$, rates were $18-27 \%$ in Belleview.

Figure 7-6: Denver Vacancy Rates for Region, Cities and Select Centers, 2000-2008-2012

\begin{tabular}{|c|c|c|c|c|}
\hline \multirow[t]{2}{*}{ Area } & \multirow[t]{2}{*}{$\begin{array}{l}\text { Transit Line \& Opening } \\
\text { Date }\end{array}$} & \multicolumn{3}{|c|}{ Vacancy Rate } \\
\hline & & 2000 & $2008-2012$ & Diff. \\
\hline $\begin{array}{l}\text { DRCOG Region (Adams, Arapahoe, Boulde } \\
\text { Clear Creek, Denver, Douglas, Gilpin, } \\
\text { Jefferson, Weld Counties ) }\end{array}$ & & $4 \%$ & $6 \%$ & $2 \%$ \\
\hline Arvada & & $2 \%$ & $4 \%$ & $2 \%$ \\
\hline Aurora & & $3 \%$ & $7 \%$ & $4 \%$ \\
\hline Hampden Town Center & Southeast - 2006 & $4 \%$ & $13 \%$ & $9 \%$ \\
\hline I-225/Parker Road & Southeast - 2006 & $4 \%$ & $7 \%$ & $3 \%$ \\
\hline Centennial & & & $3 \%$ & $3 \%$ \\
\hline Denver & & $5 \%$ & $8 \%$ & $3 \%$ \\
\hline Alameda Station & Central - 1994 & $5 \%$ & $6 \%$ & $1 \%$ \\
\hline Belleview Station & Southeast - 2006 & $18 \%$ & $27 \%$ & $9 \%$ \\
\hline Broadway Station & Central - 1994 & $4 \%$ & $8 \%$ & $3 \%$ \\
\hline Colorado Station & Southeast - 2006 & $3 \%$ & $7 \%$ & $5 \%$ \\
\hline Southmoor Park TOD & Southeast - 2006 & $2 \%$ & $3 \%$ & $1 \%$ \\
\hline Englewood & & $4 \%$ & $7 \%$ & $4 \%$ \\
\hline Greenwood Village & & $5 \%$ & $8 \%$ & $3 \%$ \\
\hline Lakewood & & $3 \%$ & $6 \%$ & $3 \%$ \\
\hline Oak Street & West - 2014 & $5 \%$ & $9 \%$ & $4 \%$ \\
\hline Wadsworth Boulevard & West - 2014 & $4 \%$ & $11 \%$ & $7 \%$ \\
\hline Lone Tree & & $3 \%$ & $5 \%$ & $2 \%$ \\
\hline Lincoln Station & Southeast - 2006 & $15 \%$ & $5 \%$ & $-10 \%$ \\
\hline Thornton & & $2 \%$ & $4 \%$ & $2 \%$ \\
\hline Eastlake & North Metro -2018 & $24 \%$ & $5 \%$ & $-19 \%$ \\
\hline Westminster & & $2 \%$ & $4 \%$ & $2 \%$ \\
\hline $\begin{array}{l}\text { I25 Corridor (Centennial, Greenwood Village, } \\
\text { Denver, Lone Tree) }\end{array}$ & Southeast - 2006 & $6 \%$ & $12 \%$ & $6 \%$ \\
\hline
\end{tabular}




\subsubsection{Land Use: Housing Tenure}

Housing tenure reflects the percentage of owner and renter occupied (see Figure 7-7). A shift from owner to renter could signal construction of new multifamily homes or could reflect recessionary housing market effects. Because owner and renter are inverse, we only describe the trends in renters below.

At the regional scale, the share of renters increased slightly (2\%) to 36\%. At the city level, the trends were highly variable, but all cities saw an increase in the share of renters. The increase in renters ranged from 2\% in Arvada and Denver to $11 \%$ in Greenwood Village. Overall, there is considerable variable in the renter/owner split.

In examining trends along transit lines, both stations on the Central line saw decreases in renters. Stations along the Southeast line were variable-while most increased the share of rents, Belleview and Colorado Station decreased in the share of renters. This could reflect an increasing condo market. Along the Southeast line, some stations saw large increases in renters including Lone Tree (at $83 \%$ ) and at $28 \%$. In both centers, the total population is low (below 350), so the increase reflects a small base. The changes in centers on the West line were modest at around $1 \%$. The only station along the North Metro line, Eastlake, increased the share of renters by $10 \%$.

In examining centers within cities, the trends are interesting. In Aurora, the share of renters increased in both centers and at the city level. In Denver, the city increased in renters but all centers except Southmoor decreased in the share of renters. In Lone Tree and Thornton, the share of renters increased faster than at the city level. In Lakewood, changes were slight but mixed. In I-25, the share of renters increased by $10 \%$. 
Figure 7-7: Denver Owner/Renter Share for Region, Cities and Select Centers, 2000-20082012

\begin{tabular}{|c|c|c|c|c|c|c|c|}
\hline \multirow[t]{2}{*}{ Area } & \multirow{2}{*}{$\begin{array}{l}\text { Transit Line \& } \\
\text { Opening Date }\end{array}$} & \multicolumn{3}{|c|}{$\%$ Owner } & \multicolumn{3}{|c|}{$\%$ Renter } \\
\hline & & 2000 & $\begin{array}{l}2008- \\
2012\end{array}$ & Diff. & 2000 & $\begin{array}{l}2008- \\
2012\end{array}$ & Diff. \\
\hline $\begin{array}{l}\text { DRCOG Region (Adams, Arapahoe, Boulde } \\
\text { Clear Creek, Denver, Douglas, Gilpin, } \\
\text { Jefferson, Weld Counties ) }\end{array}$ & & $66 \%$ & $64 \%$ & $-2 \%$ & $34 \%$ & $36 \%$ & $2 \%$ \\
\hline Arvada & & $76 \%$ & $73 \%$ & $-2 \%$ & $24 \%$ & $27 \%$ & $2 \%$ \\
\hline Aurora & & $64 \%$ & $60 \%$ & $-4 \%$ & $36 \%$ & $40 \%$ & $4 \%$ \\
\hline Hampden Town Center & Southeast - 2006 & $38 \%$ & $25 \%$ & $-12 \%$ & $62 \%$ & $75 \%$ & $12 \%$ \\
\hline I-225/Parker Road & Southeast - 2006 & $64 \%$ & $52 \%$ & $-12 \%$ & $36 \%$ & $48 \%$ & $12 \%$ \\
\hline Centennial & & & $83 \%$ & $83 \%$ & & $17 \%$ & \\
\hline Denver & & $52 \%$ & $50 \%$ & $-2 \%$ & $48 \%$ & $50 \%$ & $2 \%$ \\
\hline Alameda Station & Central - 1994 & $37 \%$ & $39 \%$ & $2 \%$ & $63 \%$ & $61 \%$ & $-2 \%$ \\
\hline Belleview Station & Southeast - 2006 & $4 \%$ & $7 \%$ & $4 \%$ & $96 \%$ & $93 \%$ & $-4 \%$ \\
\hline Broadway Station & Central - 1994 & $44 \%$ & $46 \%$ & $1 \%$ & $56 \%$ & $54 \%$ & $-1 \%$ \\
\hline Colorado Station & Southeast - 2006 & $36 \%$ & $37 \%$ & $1 \%$ & $64 \%$ & $63 \%$ & $-1 \%$ \\
\hline Southmoor Park TOD & Southeast - 2006 & $90 \%$ & $62 \%$ & $-28 \%$ & $10 \%$ & $38 \%$ & $28 \%$ \\
\hline Englewood & & $52 \%$ & $49 \%$ & $-3 \%$ & $48 \%$ & $51 \%$ & $3 \%$ \\
\hline Greenwood Village & & $77 \%$ & $65 \%$ & $-11 \%$ & $23 \%$ & $35 \%$ & $11 \%$ \\
\hline Lakewood & & $61 \%$ & $59 \%$ & $-2 \%$ & $39 \%$ & $41 \%$ & $2 \%$ \\
\hline Oak Street & West - 2014 & $37 \%$ & $36 \%$ & $0 \%$ & $63 \%$ & $64 \%$ & $0 \%$ \\
\hline Wadsworth Boulevard & West - 2014 & $24 \%$ & $26 \%$ & $1 \%$ & $76 \%$ & $74 \%$ & $-1 \%$ \\
\hline Lone Tree & & $78 \%$ & $70 \%$ & $-7 \%$ & $22 \%$ & $30 \%$ & $7 \%$ \\
\hline Lincoln Station & Southeast - 2006 & $97 \%$ & $14 \%$ & $-83 \%$ & $3 \%$ & $86 \%$ & $83 \%$ \\
\hline Thornton & & $78 \%$ & $70 \%$ & $-7 \%$ & $22 \%$ & $30 \%$ & $7 \%$ \\
\hline Eastlake & North Metro -2018 & $14 \%$ & $4 \%$ & $-10 \%$ & $86 \%$ & $96 \%$ & $10 \%$ \\
\hline Westminster & & $70 \%$ & $65 \%$ & $-4 \%$ & $30 \%$ & $35 \%$ & $4 \%$ \\
\hline $\begin{array}{l}\text { I25 Corridor (Centennial, Greenwood Village, } \\
\text { Denver, Lone Tree) }\end{array}$ & Southeast - 2006 & $38 \%$ & $28 \%$ & $-10 \%$ & $62 \%$ & $72 \%$ & $10 \%$ \\
\hline
\end{tabular}




\subsubsection{Transportation: Network}

Baseline transportation conditions are conveyed in Figure 7-8. Because these metrics were computed only at the center level, Figure 7-8 only conveys centers.

Normalized data is easier to compare across urban centers since the land area varies drastically across centers. In examining transportation trends, we examine static data about the transportation network reflecting conditions for 2014. As a result, we focus on cul-de-sac ratio, average street length, bus stop density, bus route density and light rail stop density.

The cul-de-sac ratio varies from 0.00 for centers with no cul-de-sac to 0.05 for centers with a higher level of cul-de-sacs. Interesting, the highest ratio (Colorado Station) and lowest (Belleview) were both in Denver. That indicates that Denver represents grid-like urban form and more suburban urban form with more dead ends. The numbers in all other centers vary from 0.00 to 0.04 , with no clear trends emerging by city or rail line.

Average street length provides an indication of the size of blocks. A lower street length is a more walkable environment, while a longer street length is less walkable. Average street lengths range from 325 feet in Alameda (Denver) to 697 feet in Lincoln (Lone Tree.) Generally, street lengths are shorter on average in Denver and first-tier suburbs like Aurora and longer in newer suburbs like Lone Tree and Thornton.

The number of bus stops, bus routes and light rail helps assess the availability of alternative modes in the center. It is important to note that although some of these centers have light rail stations adjacent to the center (like Hampden and Southmoor,) the actual station area is outside of the urban center. The density of bus stops ranges from 0 in Hampden Eastlake to 101 bus stops per square mile in Southmoor. In general, the Denver stations have a higher bus stop density though Parker and Wadsworth have a high density as well. The bus route trends are consistent with bus stops. Light rail stop density varies across centers from 0 in Hampden and Eastlake to 10.45 per square mile in Lincoln (Lone Tree.) Most centers (except I-25) only have one light rail station, so this is more a reflection of the areal size of the center than greater accessibility to transit. 
Figure 7-8: Denver Transportation Network Characteristics for Region, Cities and Select Centers, 2000-2008-2012

\begin{tabular}{|c|c|c|c|c|c|c|c|c|c|c|c|}
\hline \multirow[t]{2}{*}{ Area } & \multirow[t]{2}{*}{$\begin{array}{c}\text { Transit Line \& Opening } \\
\text { Date }\end{array}$} & $\begin{array}{l}\text { Number } \\
\text { of Cul- } \\
\text { de-sacs }\end{array}$ & $\begin{array}{l}\text { Cul-de- } \\
\text { sac } \\
\text { Density }\end{array}$ & $\begin{array}{l}\text { Length } \\
\text { of } \\
\text { Streets }\end{array}$ & $\begin{array}{l}\text { Average } \\
\text { Block } \\
\text { Lengths }\end{array}$ & $\begin{array}{l}\text { Bus } \\
\text { stops }\end{array}$ & $\begin{array}{l}\text { Bus } \\
\text { Routes }\end{array}$ & $\begin{array}{l}\text { Light Rail } \\
\text { Stops }\end{array}$ & $\begin{array}{l}\text { Bus Stop } \\
\text { Density }\end{array}$ & $\begin{array}{l}\text { Bus } \\
\text { Route } \\
\text { Density }\end{array}$ & $\begin{array}{l}\text { Light Rail } \\
\text { Stop } \\
\text { Density }\end{array}$ \\
\hline & & \multicolumn{10}{|c|}{2014 Static Data } \\
\hline \multicolumn{12}{|l|}{ Aurora } \\
\hline Hampden Town Center & Southeast - 2006 & 3 & 18.34 & 13,045 & 416 & 0 & 0 & 0 & 0 & 0 & 0 \\
\hline I-225/Parker Road & Southeast - 2006 & 6 & 18.34 & 19,816 & 434 & 14 & 11 & 0 & 43 & 34 & 0 \\
\hline \multicolumn{12}{|l|}{ Denver } \\
\hline Alameda Station & Central - 1994 & 1 & 3.19 & 24,634 & 325 & 14 & 9 & 1 & 45 & 29 & 3 \\
\hline Belleview Station & Southeast - 2006 & 0 & 0.00 & 16,729 & 377 & 4 & 4 & 1 & 34 & 34 & 9 \\
\hline Broadway Station & Central - 1994 & 2 & 8.80 & 18,475 & 425 & 12 & 8 & 1 & 53 & 35 & 4 \\
\hline Colorado Station & Southeast - 2006 & 8 & 29.86 & 27,884 & 375 & 18 & 7 & 1 & 67 & 26 & 4 \\
\hline Southmoor Park TOD & Southeast - 2006 & 0 & 0.00 & - & - & 8 & 6 & 0 & 102 & 76 & 0 \\
\hline \multicolumn{12}{|l|}{ Lakewood } \\
\hline Oak Street & West - 2014 & 4 & 8.91 & 31,519 & 449 & 14 & 5 & 1 & 31 & 11 & 2 \\
\hline Wadsworth Boulevard & West - 2014 & 12 & 26.14 & 54,721 & 383 & 20 & 7 & 1 & 44 & 15 & 2 \\
\hline \multicolumn{12}{|l|}{ Lone Tree } \\
\hline Lincoln Station & Southeast - 2006 & 1 & 10.45 & 7,012 & 697 & 2 & 3 & 1 & 21 & 31 & 10 \\
\hline \multicolumn{12}{|l|}{ Thornton } \\
\hline Eastlake & North Metro -2018 & 1 & 6.44 & 8,620 & 516 & 0 & 0 & 0 & 0 & 0 & 0 \\
\hline $\begin{array}{l}\text { I25 Corridor (Centennial, } \\
\text { Greenwood Village, Denver, } \\
\text { Lone Tree) }\end{array}$ & Southeast - 2006 & 147 & 15.86 & 601,987 & 459 & 118 & 18 & 4 & 13 & 2 & 0 \\
\hline
\end{tabular}




\subsubsection{Transportation: Transit Share}

We examine trends in transit ridership and alternative modes for 2000 to 2008-2012, as shown in Figure 7-9. Examining the mode split between 2000-2008-2012 provides interesting insights into trends within regions, cities and urban centers. At the regional level, there was no difference in the share of commuters using transit between 2000 and 2008-2012. Within cities, the share of transit increased in Aurora, Englewood, Greenwood Village, Lakewood and Lone Tree. In Denver and Thornton, the share by transit actually decreased slightly.

Overall, the relative levels of transit varies across cities. In Denver and Englewood, around 7-8\% of workers take transit. In Lone Tree, the shares are 3\%. In examining trends by transit line, all of the centers on the Southeast Line saw increases in ridership between 2000 and 2008-2012. These increases ranged from 3\% in Southmoor, Belleview and Lincoln to 9\% in Colorado Station. Along the West Line and North Metro Line, which were not yet open, the trends were variable. Eastlake and Oak Street declined while Wadsworth increased by 9\%. Along the Central Line in Denver, Alameda increased slightly but Broadway decreased slightly. Cities and centers were not always consistent with one another as far as transit share went, pointing to the high level of variability within cities. 
Figure 7-9: Denver Transit Share for Region, Cities and Select Centers, 2000-2008-2012

\begin{tabular}{|c|c|c|c|c|}
\hline \multirow[t]{2}{*}{ Area } & \multirow{2}{*}{$\begin{array}{l}\text { Transit Line \& Opening } \\
\text { Date }\end{array}$} & \multicolumn{3}{|c|}{ \% Transit } \\
\hline & & 2000 & 2008-2012 & Diff. \\
\hline $\begin{array}{l}\text { DRCOG Region (Adams, Arapahoe, Boulde } \\
\text { Clear Creek, Denver, Douglas, Gilpin, } \\
\text { Jefferson, Weld Counties) }\end{array}$ & & $4 \%$ & $4 \%$ & $0 \%$ \\
\hline Arvada & & $3 \%$ & $3 \%$ & $0 \%$ \\
\hline $\begin{array}{l}\text { Aurora } \\
\text { Hampden Town Center } \\
\text { I-225/Parker Road }\end{array}$ & $\begin{array}{l}\text { Southeast - } 2006 \\
\text { Southeast - } 2006\end{array}$ & $\begin{array}{l}4 \% \\
4 \% \\
4 \%\end{array}$ & $\begin{array}{r}6 \% \\
8 \% \\
11 \%\end{array}$ & $\begin{array}{l}2 \% \\
4 \% \\
7 \%\end{array}$ \\
\hline Centennial & & $\mathrm{N} / \mathrm{A}$ & $3 \%$ & N/A \\
\hline $\begin{array}{l}\text { Denver } \\
\text { Alameda Station } \\
\text { Belleview Station } \\
\text { Broadway Station } \\
\text { Colorado Station } \\
\text { Southmoor Park TOD }\end{array}$ & $\begin{array}{l}\text { Central - } 1994 \\
\text { Southeast - } 2006 \\
\text { Central - } 1994 \\
\text { Southeast - } 2006 \\
\text { Southeast - } 2006\end{array}$ & $\begin{array}{r}8 \% \\
11 \% \\
0 \% \\
15 \% \\
2 \% \\
5 \%\end{array}$ & $\begin{array}{r}7 \% \\
12 \% \\
3 \% \\
11 \% \\
11 \% \\
8 \%\end{array}$ & $\begin{array}{r}-1 \% \\
1 \% \\
3 \% \\
-4 \% \\
9 \% \\
3 \%\end{array}$ \\
\hline Englewood & & $5 \%$ & $8 \%$ & $3 \%$ \\
\hline Greenwood Village & & $1 \%$ & $4 \%$ & $2 \%$ \\
\hline $\begin{array}{l}\text { Lakewood } \\
\text { Oak Street } \\
\text { Wadsworth Boulevard }\end{array}$ & $\begin{array}{l}\text { West - } 2014 \\
\text { West - } 2014\end{array}$ & $\begin{array}{l}4 \% \\
8 \% \\
3 \% \\
\end{array}$ & $\begin{array}{r}5 \% \\
7 \% \\
12 \% \\
\end{array}$ & $\begin{array}{r}1 \% \\
-1 \% \\
9 \% \\
\end{array}$ \\
\hline $\begin{array}{l}\text { Lone Tree } \\
\text { Lincoln Station }\end{array}$ & Southeast - 2006 & $\begin{array}{l}2 \% \\
0 \%\end{array}$ & $\begin{array}{l}3 \% \\
3 \%\end{array}$ & $\begin{array}{l}1 \% \\
3 \%\end{array}$ \\
\hline $\begin{array}{l}\text { Thornton } \\
\text { Eastlake }\end{array}$ & North Metro -2018 & $\begin{array}{l}4 \% \\
2 \%\end{array}$ & $\begin{array}{l}3 \% \\
1 \%\end{array}$ & $\begin{array}{l}-1 \% \\
-1 \%\end{array}$ \\
\hline Westminster & & $4 \%$ & $4 \%$ & $0 \%$ \\
\hline $\begin{array}{l}\text { I25 Corridor (Centennial, Greenwood Village, } \\
\text { Denver, Lone Tree) }\end{array}$ & Southeast - 2006 & $1 \%$ & $6 \%$ & $5 \%$ \\
\hline
\end{tabular}




\subsubsection{Transportation: Alternative Mode Share}

While trends in transit mode varied considerably, the share of bike, walk and transit trips combined increased pretty consistently across the region, cities and centers. More specifically, the regional share increased slightly, and all cities saw either no change or a positive increase in the share of alternative modes. The increase was highest in Greenwood Village where the share increased by four percentage points. Westminster, Thornton and Denver remained steady.

In looking at alternative mode share by transit line, all of the centers on the Southeast line saw increases in alternative mode share, ranging from $2 \%$ in Belleview and Southmoor to $8 \%$ in Colorado Station. Along the Central line, Alameda increased by $5 \%$ but Broadway decreased by $1 \%$. Along the Western Line, trends were mixed as Oak Street declined by $2 \%$ and Wadsworth increased by $11 \%$. The only station North Metro, Eastlake, increased slightly.

Like transit share, cities and centers were not always consistent. Because most centers and cities increased these trends were consistent, but in Denver and Lakewood the picture was mixed.

\subsubsection{Transportation: Car Ownership}

Finally, we examined trends in car ownership focusing on the share of households with no or one car as shown in Figure 7-11. This serves as a proxy for households driving less, as VMT is not available at the center scale. We refer to these households as "low-car" households.

At the regional level, the share of households with one car or less declined by $1 \%$. In Denver, the share of low-car households decreased by $2 \%$ from $57 \%$ to 55\%. At the city scale, the difference ranged from $0 \%$ in Aurora to $11 \%$ increase in low-car households in Greenwood Village. However, only 31\% of Greenwood Village households were low-car in 2008-2012 data while 55\% of Denver households were low-car.

At the center level, the data was variable and inconclusive. Several centers saw very high increases in low-car households, which could represent centers attracting individuals who drive less. Only one center saw a drop in low-car households: Oak Street in Lakewood. These data could also represent the decline in household size. The format of data made it very difficult to gather information like number of cars per household or understand the relationship between city size. As a result, we do not go into great depth about the data at the center level. 
Figure 7-10: Denver Alternative Mode Share for Region, Cities and Select Centers, 20002008-2012

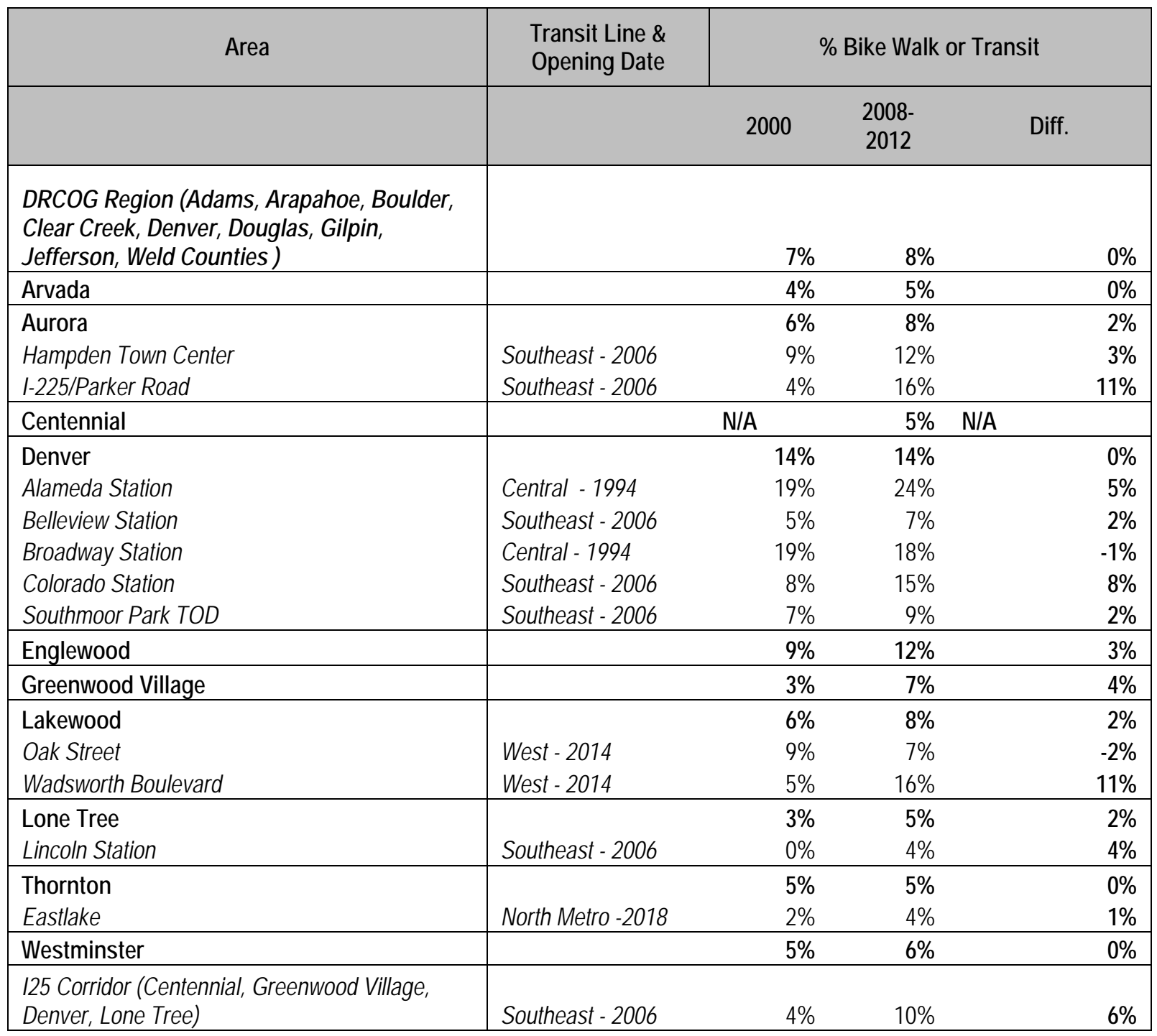


Figure 7-11: Denver Car Ownership (Share with 0 or 1 Car) for Region, Cities and Select Centers, 2000-2008-2012

\begin{tabular}{|c|c|c|c|c|}
\hline \multirow[t]{2}{*}{ Area } & \multirow[t]{2}{*}{$\begin{array}{l}\text { Transit Line \& } \\
\text { Opening Date }\end{array}$} & \multicolumn{3}{|c|}{$\%$ Households with 0 or 1 Car } \\
\hline & & 2000 & $\begin{array}{l}2008- \\
2012\end{array}$ & Diff. \\
\hline $\begin{array}{l}\text { DRCOG Region (Adams, Arapahoe, Boulde } \\
\text { Clear Creek, Denver, Douglas, Gilpin, } \\
\text { Jefferson, Weld Counties ) }\end{array}$ & & $40 \%$ & $39 \%$ & $-1 \%$ \\
\hline Arvada & & $32 \%$ & $34 \%$ & $2 \%$ \\
\hline Aurora & & $44 \%$ & $45 \%$ & $0 \%$ \\
\hline Hampden Town Center & Southeast - 2006 & $25 \%$ & $67 \%$ & $42 \%$ \\
\hline I-225/Parker Road & Southeast - 2006 & $39 \%$ & $63 \%$ & $24 \%$ \\
\hline Centennial & & N/A & $26 \%$ & N/A \\
\hline Denver & & $57 \%$ & $55 \%$ & $-2 \%$ \\
\hline Alameda Station & Central - 1994 & $60 \%$ & $65 \%$ & $6 \%$ \\
\hline Belleview Station & Southeast - 2006 & $16 \%$ & $76 \%$ & $60 \%$ \\
\hline Broadway Station & Central - 1994 & $42 \%$ & $56 \%$ & $14 \%$ \\
\hline Colorado Station & Southeast - 2006 & $26 \%$ & $70 \%$ & $45 \%$ \\
\hline Southmoor Park TOD & Southeast - 2006 & $25 \%$ & $39 \%$ & $13 \%$ \\
\hline Englewood & & $51 \%$ & $54 \%$ & $3 \%$ \\
\hline Greenwood Village & & $20 \%$ & $31 \%$ & $11 \%$ \\
\hline Lakewood & & $42 \%$ & $44 \%$ & $2 \%$ \\
\hline Oak Street & West - 2014 & $60 \%$ & $56 \%$ & $-4 \%$ \\
\hline Wadsworth Boulevard & West - 2014 & $35 \%$ & $77 \%$ & $42 \%$ \\
\hline Lone Tree & & $23 \%$ & $31 \%$ & $8 \%$ \\
\hline Lincoln Station & Southeast - 2006 & $31 \%$ & $46 \%$ & $14 \%$ \\
\hline Thornton & & $30 \%$ & $31 \%$ & $1 \%$ \\
\hline Eastlake & North Metro -2018 & $20 \%$ & $59 \%$ & $39 \%$ \\
\hline Westminster & & $34 \%$ & $35 \%$ & $2 \%$ \\
\hline $\begin{array}{l}\text { I25 Corridor (Centennial, Greenwood Village, } \\
\text { Denver, Lone Tree) }\end{array}$ & Southeast - 2006 & $18 \%$ & $62 \%$ & $45 \%$ \\
\hline
\end{tabular}

\subsubsection{Synthesis of Denver Results}

This section conveyed changes in demographic, land use and transportation metrics from 2000 to 2010 (or 2008-2012.) During this period, the country experienced the Great Recession, affecting the economy while Denver expanded the transit network and grew in population. We only examined a subset of centers by transit line and city; thus, we caution drawing generalizations by transit line or city. In synthesizing information across indicators, some trends emerge.

Only two centers along the Central line in Denver increased in income, and these same two centers were poor performing on other metrics. Both lost population and housing units, and the mode share in transit and alternative modes declined. It is possible that we caught these centers 
in a wave of gentrification to higher-income, more auto-dependent households. The share of owners also increased in these centers, which could indicate owner-occupied condos replacing apartments.

Most centers declined in income (in 2012 dollars) due to the recession. Additionally, vacancy rates increased in all centers except Lincoln Station and Thornton.

With rare exceptions, the stations on the Southeast line (in Denver, Lone Tree, I-25 Corridor, and Aurora) increased in population, housing units, transit ridership, low-car households, and alternative mode share. Only Colorado Station in Denver showed a loss in population.

The West line opened in 2014. Two centers in Lakewood showed mixed results in declining in population, housing units and income, and showed little change in housing tenure. However, the Wadsworth station showed significant increases in transit and alternative mode share as well as the share of low-car households, perhaps indicative of people moving to the center for the amenity of the transit station before it opened.

The North Metro line will not open until 2018. The Eastlake center was a greenfield in 2000 and developed on a small scale between 2000-2008-2012, but the small numbers make it difficult to interpret trends.

These trends tell the story of transit and centers influencing development in different ways. The influence of the recession creates noise in the data. Some stations tend to show signs of gentrification through these data, but several stations show positive trends towards the goals desired by DRCOG. Across many centers, population and housing units are increasing faster than the regional or city average while transit ridership and alternative mode shares are growing. Additionally, there has been an increase in renters in several centers, trending towards greater balance in renters and owners and indicating a mix of housing types.

\subsection{Salt Lake Findings}

The tables below present three categories of data for Salt Lake City, conveying regional, citylevel, and center-level information for case study cities. We describe trends in levels, change over time below, and compare urban centers to the trends within the city and region.

\subsubsection{Demographic: Population, Density and Land Area}

As shown in Figure 7-12, overall population in the Salt Lake region increased by $18 \%$. Of this $18 \%$ increase in population, $23 \%$ of the growth went to our case study cities. Only $2 \%$ of the population growth went into Salt Lake City. Most cities saw an increase in population as well, including Clearfield, Lehi, Murray, Pleasant View, Salt Lake City, and South Jordan. The increase in population ranged from 3\% in Salt Lake City to 149\% in Lehi. Many of these cities also increased in land area through annexation. The most stark increases were in Lehi (30\%) and Murray (28\%.) While all cities increased in area, Sandy, Salt Lake City and Pleasant View only grew by $3 \%$. Population in Sandy decreased by $1 \%$. 
Population density increased in all cities except Sandy as well, with gains ranging from $1 \%$ in Salt Lake City to $92 \%$ in Lehi. Sandy decreased by 3\%. In examining urban centers, population gains varied considerably across urban centers. Because center area remains static, the changes in density are consistent with change in population and we only report density here. It is interesting to compare population gains by rail line and to cities within which the centers are located. Population increases along all stations located on the FrontRunner, with gains ranging from $8 \%$ in Clearfield to 259\% in Cabellas' core. Most stations along the Blue and Red lines increased in population (and density), though gains were more modest and ranged from $0 \%$ to $25 \%$. Trends in population along the Green Line were more variable as some stations increased in population by $4 \%$ but several centers declined in population. This is not surprising because the Green Line extension to the airport did not open until 2013.

The trends within cities are interesting. In Clearfield, the population increased in both centers and at the city level but the city grew faster in population. In Lehi, both centers and the city increased in population, but several of the centers grew faster than the city. In Murray, the trends were variable as Murray did not change and Fireclay increased by 25\%. The center and city both increased in population and the center grew faster than the city. In South Jordan, the city and centers also increased. In Salt Lake, the portrait was more mixed as three of five centers declined in population and only two increased. The overall population increase at the city level was also moderate. In Sandy, the city lost population (3\%) but the center increased in population.

Relative density in 2010 varies considerably across centers, from a low of 636 persons per square mile in a center in South Jordan to a high of 5,850 persons per square mile in Salt Lake’s core. 
Figure 7-12: Salt Lake Population, Density and Land Area by Region, Cities and Select Centers, 2000-2008-2012

\begin{tabular}{|c|c|c|c|c|c|c|c|c|c|c|}
\hline \multirow[t]{2}{*}{ Area } & \multirow[t]{2}{*}{ Transit Line \& Opening Date } & \multicolumn{3}{|c|}{ Area (Square Miles) } & \multicolumn{3}{|c|}{ Population } & \multicolumn{3}{|c|}{ Density (Population Per Square Mile) } \\
\hline & & 2000 & 2010 & $\%$ Change & 2000 & 2010 & $\begin{array}{c}\% \\
\text { Change }\end{array}$ & 2000 & 2010 & $\begin{array}{c}\% \\
\text { Change }\end{array}$ \\
\hline $\begin{array}{r}\text { WFRC Region (Box } \\
\text { Tooel }\end{array}$ & $\begin{array}{l}\text { der, Davis, Morgan, Salt Lake, } \\
\text { Weber Counties) }\end{array}$ & 14,880 & 14,913 & $0 \%$ & $1,424,523$ & $1,685,032$ & $18 \%$ & 96 & 113 & $18 \%$ \\
\hline Clearfield & & 8 & 8 & $-2 \%$ & 25,974 & 30,112 & $16 \%$ & 3,352 & 3,950 & $18 \%$ \\
\hline Layton & FrontRunner - 2009 & 4 & 4 & $0 \%$ & 15,276 & 16,603 & $9 \%$ & 4,065 & 4,417 & $9 \%$ \\
\hline CRT 1400 S $800 E$ & FrontRunner - 2009 & 0 & 0 & $0 \%$ & 536 & 576 & $8 \%$ & 2,729 & 2,935 & $8 \%$ \\
\hline Lehi & & 20 & 26 & $30 \%$ & 19,028 & 47,407 & $149 \%$ & 936 & 1,800 & $92 \%$ \\
\hline Cabellas Core & FrontRunner - 2009 & 1.46 & 1.46 & $0 \%$ & 660 & 2,365 & $259 \%$ & 451 & 1,619 & $259 \%$ \\
\hline No Name 7353 & $\mathrm{~N} / \mathrm{A}$ & 0.20 & 0.20 & $0 \%$ & 454 & 532 & $17 \%$ & 2,313 & 2,712 & $17 \%$ \\
\hline No Name 7151 & $\mathrm{~N} / \mathrm{A}$ & 0.20 & 0.20 & $0 \%$ & 40 & 455 & $1038 \%$ & 204 & 2,320 & $1038 \%$ \\
\hline Murray & & 10 & 12 & $28 \%$ & 34,024 & 46,746 & $37 \%$ & 3,542 & 3,803 & $7 \%$ \\
\hline Murray & Blue Line - 2000 & 2 & 2 & $0 \%$ & 6,557 & 6,529 & $0 \%$ & 3,038 & 3,025 & $0 \%$ \\
\hline Fireclay & Red Line - 2000 & 0 & 0 & $0 \%$ & 296 & 369 & $25 \%$ & 1,509 & 1,880 & $25 \%$ \\
\hline Pleasant View & & 7 & 7 & $3 \%$ & 5,632 & 7,979 & $42 \%$ & 837 & 1,155 & $38 \%$ \\
\hline Pleasant View & FrontRunner - 2009 & 0.47 & 0.47 & $0 \%$ & 226 & 484 & $114 \%$ & 485 & 1,040 & $114 \%$ \\
\hline
\end{tabular}


Figure 7-12: (continued) Salt Lake Population, Density and Land Area by Region, Cities and Select Centers, 2000-2008-2012

\begin{tabular}{|c|c|c|c|c|c|c|c|c|c|c|}
\hline \multirow{2}{*}{ Area } & \multirow{2}{*}{ Transit Line \& Opening Date } & \multicolumn{3}{|c|}{ Area (Square Miles) } & \multicolumn{3}{|c|}{ Population } & \multicolumn{3}{|c|}{ Density (Population Per Square Mile) } \\
\hline & & 2000 & 2010 & $\%$ Change & 2000 & 2010 & $\begin{array}{r}\% \\
\text { Change }\end{array}$ & 2000 & 2010 & $\begin{array}{r}\% \\
\text { Change }\end{array}$ \\
\hline Salt Lake City & & 109 & 111 & $2 \%$ & 181,743 & 186,440 & $3 \%$ & 1,666 & 1,678 & $1 \%$ \\
\hline Salt Lake Core & Blue, Red, Green - 2000-2008 & 5.11 & 5.11 & $0 \%$ & 30,420 & 29,876 & $-2 \%$ & 5,956 & 5,850 & $-2 \%$ \\
\hline Temple & Green Line - 2013 & 0.20 & 0.20 & $0 \%$ & 1,070 & 1,117 & $4 \%$ & 5,453 & 5,690 & $4 \%$ \\
\hline Temple & Green Line - 2013 & 0.20 & 0.20 & $0 \%$ & 923 & 851 & $-8 \%$ & 4,704 & 4,333 & $-8 \%$ \\
\hline $\begin{array}{l}\text { LRT } 825 \text { W North } \\
\text { Temple }\end{array}$ & Green Line - 2013 & 0.20 & 0.20 & $0 \%$ & 832 & 814 & $-2 \%$ & 4,239 & 4,148 & $-2 \%$ \\
\hline Temple & Green Line - 2013 & 0.20 & 0.20 & $0 \%$ & 757 & 763 & $1 \%$ & 3,858 & 3,887 & $1 \%$ \\
\hline Sandy & & 22 & 23 & $2 \%$ & 88,418 & 87,461 & $-1 \%$ & 3,960 & 3,825 & $-3 \%$ \\
\hline Sandy $C B D$ & Blue Line - 2000, 2006 & 2 & 2 & $0 \%$ & 4,244 & 4,576 & $8 \%$ & 1,810 & 1,951 & $8 \%$ \\
\hline South Jordan & & 21 & 22 & $6 \%$ & 29,437 & 50,418 & $71 \%$ & 1,411 & 2,286 & $62 \%$ \\
\hline Daybreak & Red Line - 2011 & 1.50 & 1.50 & $0 \%$ & 180 & 1,030 & $472 \%$ & 120 & 686 & $472 \%$ \\
\hline NoName 9875 & $\mathrm{~N} / \mathrm{A}$ & 0.20 & 0.20 & $0 \%$ & 441 & 636 & $44 \%$ & 2,245 & 3,240 & $44 \%$ \\
\hline
\end{tabular}




\subsubsection{Demographic: Housing Units}

The number of housing units reflects the change in the urban fabric. While trends are somewhat consistent with population, differences exist because of changing household size and vacancy rates. Trends for Salt Lake are conveyed in Figure 7-13.

In the region, the total number of housing units increased by $21 \%$. At the city level, the total number of housing units increased in all cities. Gains ranged from 5\% Salt Lake City to 147\% in Lehi. The number of housing units increased faster than population in all cities, which could reflect the housing boom in the 2000s or smaller household sizes.

At the center level, the trends were mixed. Along the FrontRunner line, all centers increased in the number of housing units, ranging from 9\% in Layton to 317\% in Cabellas' core. Similar trends were seen on the Blue and Red lines, where increases ranged from 1\% in Murray to 431\% in Daybreak. Trends on the Green Line airport extension were more variable as the number of units declined in some centers, including 1900 W North Temple and 1500 W N Temple.

Within cities, the center trends generally reflected the same trends as population. All of the centers in Clearfield, Lehi, Murray, Pleasant View, Sandy and South Jordan increased in housing units alongside the cities. The gains were variable relative to city population increase. In Sandy, Pleasant View and Murray, centers consistently grew faster than cities in housing units. But Clearfield, Lehi and South Jordan showed variables in the pace of growth in centers v. the city. In Salt Lake, overall growth was 5\% and centers within ranged from $-7 \%$ to $8 \%$. The centers that lost housing units were along the Green Line, which opened in 2013, so the loss in units could reflect construction of the line. 
Figure 7-13: Salt Lake Housing Units by Region, Cities and Select Centers, 2000-2008-2012

\begin{tabular}{|c|c|c|c|c|}
\hline \multirow[b]{2}{*}{ Area } & \multirow[b]{2}{*}{ Transit Line \& Opening Date } & \multicolumn{3}{|c|}{ Housing Units } \\
\hline & & 2000 & 2010 & $\%$ Change \\
\hline $\begin{array}{l}\text { WFRC Region (Box Elder, Davis, Morgan, Salt } \\
\text { Lake, Tooele, Weber Counties) }\end{array}$ & & 485,735 & 587,575 & $21 \%$ \\
\hline Clearfield & & 8,374 & 10,062 & $20 \%$ \\
\hline Layton & FrontRunner - 2009 & 6,093 & 6,659 & $9 \%$ \\
\hline CRT $1400 S 800 E$ & FrontRunner - 2009 & 198 & 246 & $24 \%$ \\
\hline Lehi & & 5,280 & 13,064 & $147 \%$ \\
\hline Cabellas Core & FrontRunner - 2009 & 179 & 748 & $317 \%$ \\
\hline No Name 7353 & $\mathrm{~N} / \mathrm{A}$ & 150 & 165 & $10 \%$ \\
\hline No Name 7151 & $\mathrm{~N} / \mathrm{A}$ & 11 & 120 & $999 \%$ \\
\hline Murray & & 13,327 & 19,181 & $44 \%$ \\
\hline Murray & Blue Line - 2000 & 2,563 & 2,598 & $1 \%$ \\
\hline Fireclay & Red Line - 2000 & 124 & 174 & $41 \%$ \\
\hline Pleasant View & & 1,895 & 2,548 & $34 \%$ \\
\hline Pleasant View & FrontRunner - 2009 & 86 & 148 & $72 \%$ \\
\hline Salt Lake City & & 77,054 & 80,724 & $5 \%$ \\
\hline Salt Lake Core & Blue, Red, Green - 2000-2008 & 16,726 & 16,931 & $1 \%$ \\
\hline LRT 1900 W North Temple & Green Line - 2013 & 363 & 339 & $-7 \%$ \\
\hline LRT 1500 W North Temple & Green Line - 2013 & 351 & 346 & $-1 \%$ \\
\hline LRT 825 W North Temple & Green Line - 2013 & 284 & 306 & $8 \%$ \\
\hline LRT 1100 W North Temple & Green Line - 2013 & 244 & 250 & $3 \%$ \\
\hline Sandy & & 26,579 & 29,501 & $11 \%$ \\
\hline Sandy CBD & Blue Line - 2000, 2006 & 1,513 & 1,794 & $19 \%$ \\
\hline South Jordan & & 7,721 & 14,943 & $94 \%$ \\
\hline Daybreak & Red Line - 2011 & 53 & 280 & $431 \%$ \\
\hline NoName 9875 & $\mathrm{~N} / \mathrm{A}$ & 143 & 245 & $71 \%$ \\
\hline
\end{tabular}




\subsubsection{Demographic: Household Income}

Before discussing trends in household income, it is important to note the recession's impacts on income. While 2000 was the height of the technology bubble, 2008-2012 was the bottom of the Great Recession. All values are reported in 2012 dollars. The declines in household income could relate to inflation values or job loss. It is difficult to disentangle. Additionally, it is difficult to comprehend whether losses resulted because of a shift in housing type (single-family to multifamily) or because of losses for existing families. As a result, we focus on relative values rather than percent change.

Household income declined at the regional level by 9\%. Household income in all cities declined by $2-16 \%$, with the smallest decline in Pleasant View and Lehi (2\%). The largest decline was Sandy at $16 \%$.

At the center level, the trends were variable. While some centers including Clearfield and Fireclay declined in household income, most centers actually saw increases in household income, which is counter to results at the city level and in Denver. The gains ranged from 8\% in $825 \mathrm{~W}$ North Temple to $82 \%$ in Pleasant View. Coupled with an increasing number of housing units, this could mean centers were gentrifying during the recession. 
Figure 7-14: Salt Lake Household Income (in 2012\$) by Region, Cities and Select Centers, 2000-2008-2012

\begin{tabular}{|c|c|c|c|c|}
\hline \multirow[b]{2}{*}{ Area } & \multirow[b]{2}{*}{ Transit Line \& Opening Date } & \multicolumn{3}{|c|}{ Household Income (2012 \$) } \\
\hline & & 2000 & $2008-2012$ & $\begin{array}{c}\% \\
\text { Change }\end{array}$ \\
\hline \multicolumn{2}{|c|}{$\begin{array}{l}\text { WFRC Region (Box Elder, Davis, Morgan, } \\
\text { Salt Lake, Tooele, Weber Counties) }\end{array}$} & $\$ 66,708$ & $\$ 60,663$ & $-9 \%$ \\
\hline Clearfield & & $\$ 53,668$ & $\$ 47,434$ & $-12 \%$ \\
\hline Layton & FrontRunner - 2009 & $\$ \quad 40,170$ & $\$ 47,652$ & $19 \%$ \\
\hline CRT 1400 S $800 E$ & FrontRunner - 2009 & $\$ 34,636$ & $\$ 25,130$ & $-27 \%$ \\
\hline Lehi & & $\$ 73,073$ & $\$ 71,652$ & $-2 \%$ \\
\hline Cabellas Core & FrontRunner - 2009 & 52,212 & $\$ 57,616$ & $10 \%$ \\
\hline No Name 7353 & N/A & 43,727 & $\$ 59,654$ & $36 \%$ \\
\hline No Name 7151 & $\mathrm{~N} / \mathrm{A}$ & $\$ 50,095$ & $\$ 74,166$ & $48 \%$ \\
\hline Murray & & $\$ 62,795$ & $\$ 57,104$ & $-9 \%$ \\
\hline Murray & Blue Line - 2000 & $\$ \quad 44,078$ & $\$ 51,917$ & $18 \%$ \\
\hline Fireclay & Red Line - 2000 & $\$ \quad 29,239$ & $\$ 28,820$ & $-1 \%$ \\
\hline Pleasant View & & $\$ 85,606$ & $\$ 84,072$ & $-2 \%$ \\
\hline Pleasant View & FrontRunner - 2009 & $\$ \quad 43,217$ & $\$ 78,616$ & $82 \%$ \\
\hline Salt Lake City & & $\$ 50,909$ & $\$ 44,510$ & $-13 \%$ \\
\hline Salt Lake Core & Blue, Red, Green - 2000-2008 & $\$ \quad 27,274$ & $\$ 32,146$ & $18 \%$ \\
\hline LRT 1900 W North Temple & Green Line - 2013 & 30,682 & $\$ 37,261$ & $21 \%$ \\
\hline LRT 1500 W North Temple & Green Line - 2013 & 24,348 & $\$ 37,473$ & $54 \%$ \\
\hline LRT 825 W North Temple & Green Line - 2013 & 28,802 & $\$ 31,004$ & $8 \%$ \\
\hline LRT 1100 W North Temple & Green Line - 2013 & $\$ 31,658$ & $\$ 45,943$ & $45 \%$ \\
\hline Sandy & & $\$ 91,580$ & $\$ 76,807$ & $-16 \%$ \\
\hline Sandy CBD & Blue Line - 2000, 2006 & $\$ \quad 50,265$ & $\$ 60,816$ & $21 \%$ \\
\hline South Jordan & & $\$ 103,948$ & $\$ 91,548$ & $-12 \%$ \\
\hline Daybreak & Red Line - 2011 & $\$ 69,763$ & $\$ 88,651$ & $27 \%$ \\
\hline NoName 9875 & N/A & 57,021 & $\$ 69,700$ & $22 \%$ \\
\hline
\end{tabular}

\subsubsection{Land Use: Vacancy}

Trends in vacancy rates may also reflect the recession's impacts that may have resulted in a glut of housing (see Figure 7-15). Vacancy rates increased at the regional scale by one percentage point and increased in most cities by between one to two points. Only Pleasant View saw a drop in vacancy rates at four points. Within the centers more variation existed, though nearly all centers saw increases in vacancy rates at ranges from 1-4\% (in Fireclay.) Pleasant View, Salt Lake's core, $1900 \mathrm{~W}$ North Temple and "No Name” in South Jordan saw decreases ranging from $2-8 \%$. 
Figure 7-15: Salt Lake Vacancy Rate by Region, Cities and Select Centers, 2000-2008-2012

\begin{tabular}{|c|c|c|c|c|}
\hline \multirow{2}{*}{ Area } & \multirow{2}{*}{ Transit Line \& Opening Date } & \multicolumn{3}{|c|}{ Vacancy Rate } \\
\hline & & 2000 & 2010 & Diff. \\
\hline \multicolumn{2}{|c|}{$\begin{array}{l}\text { WFRC Region (Box Elder, Davis, Morgan, } \\
\text { Salt Lake, Tooele, Weber Counties) }\end{array}$} & $5 \%$ & $6 \%$ & $1 \%$ \\
\hline Clearfield & & $5 \%$ & $7 \%$ & $2 \%$ \\
\hline Layton & FrontRunner - 2009 & $7 \%$ & $7 \%$ & $0 \%$ \\
\hline CRT 1400 S $800 E$ & FrontRunner - 2009 & $12 \%$ & $16 \%$ & $3 \%$ \\
\hline Lehi & & $3 \%$ & $5 \%$ & $2 \%$ \\
\hline Cabellas Core & FrontRunner - 2009 & $5 \%$ & $4 \%$ & $0 \%$ \\
\hline No Name 7353 & $N / A$ & $4 \%$ & $7 \%$ & $3 \%$ \\
\hline No Name 7151 & $\mathrm{~N} / \mathrm{A}$ & $1 \%$ & $3 \%$ & $2 \%$ \\
\hline Murray & & $5 \%$ & $5 \%$ & $0 \%$ \\
\hline Murray & Blue Line - 2000 & $4 \%$ & $5 \%$ & $1 \%$ \\
\hline Fireclay & Red Line - 2000 & $6 \%$ & $11 \%$ & $4 \%$ \\
\hline Pleasant View & & $8 \%$ & $4 \%$ & $-4 \%$ \\
\hline Pleasant View & FrontRunner - 2009 & $14 \%$ & $5 \%$ & $-8 \%$ \\
\hline Salt Lake City & & $7 \%$ & $8 \%$ & $0 \%$ \\
\hline Salt Lake Core & Blue, Red, Green - 2000-2008 & $12 \%$ & $10 \%$ & $-2 \%$ \\
\hline LRT 1900 W North Temple & Green Line - 2013 & $8 \%$ & $6 \%$ & $-3 \%$ \\
\hline LRT 1500 W North Temple & Green Line - 2013 & $8 \%$ & $9 \%$ & $1 \%$ \\
\hline LRT 825 W North Temple & Green Line - 2013 & $10 \%$ & $12 \%$ & $2 \%$ \\
\hline LRT 1100 W North Temple & Green Line - 2013 & $8 \%$ & $9 \%$ & $1 \%$ \\
\hline Sandy & & $3 \%$ & $4 \%$ & $1 \%$ \\
\hline Sandy CBD & Blue Line - 2000, 2006 & $6 \%$ & $8 \%$ & $1 \%$ \\
\hline South Jordan & & $3 \%$ & $4 \%$ & $1 \%$ \\
\hline Daybreak & Red Line - 2011 & $3 \%$ & $4 \%$ & $1 \%$ \\
\hline NoName 9875 & N/A & $6 \%$ & $4 \%$ & $-2 \%$ \\
\hline
\end{tabular}

\subsubsection{Land Use: Housing Tenure}

Housing tenure reflects the percentage of owner and renter occupied (see Table 7-15). A shift from owner to renter could signal construction of new multifamily homes or could reflect recessionary housing market effects. Because owner and renter are inverse, we only describe the trends in renters below.

At the regional scale the share of renters increased by 1\% between 2000 and 2008-2012. At the city scale all cities increased in the share of renters, with the exception of Clearfield where renters declined by $2 \%$. The increase in renters ranged from $0 \%$ in Murray to 5\% in Sandy and South Jordan.

In examining trends along transit lines, all centers saw increases in the share of renters, ranging from $0 \%$ in several stations to $13 \%$ in Fireclay. In examining centers within cities, the trends are interesting. All centers were consistent with the exception of Clearfield, where renters at the city scale declined, but renters increased in both centers. 
Figure 7-15: Salt Lake Housing Tenure by Region, Cities and Select Centers, 2000-20082012

\begin{tabular}{|c|c|c|c|c|c|c|c|}
\hline \multirow{2}{*}{ Area } & \multirow{2}{*}{ Transit Line \& Opening Date } & \multicolumn{3}{|c|}{ Owner } & \multicolumn{3}{|c|}{ Renter } \\
\hline & & 2000 & $\begin{array}{l}2008- \\
2012\end{array}$ & Diff. & 2000 & $\begin{array}{c}2008 \\
- \\
2012 \\
\end{array}$ & Diff. \\
\hline $\begin{array}{l}\text { WFRC Region (Box Elder, Davis, } \\
\text { Morgan, Salt Lake, Tooele, Weber } \\
\text { Counties) }\end{array}$ & & $72 \%$ & $71 \%$ & $-1 \%$ & $28 \%$ & $29 \%$ & $1 \%$ \\
\hline Clearfield & & $55 \%$ & $58 \%$ & $2 \%$ & $45 \%$ & $42 \%$ & $-2 \%$ \\
\hline Layton & FrontRunner - 2009 & $51 \%$ & $49 \%$ & $-2 \%$ & $49 \%$ & $51 \%$ & $2 \%$ \\
\hline CRT 1400 S $800 E$ & FrontRunner - 2009 & $26 \%$ & $26 \%$ & $0 \%$ & $74 \%$ & $74 \%$ & $0 \%$ \\
\hline Lehi & & $81 \%$ & $80 \%$ & $-1 \%$ & $19 \%$ & $20 \%$ & $1 \%$ \\
\hline Cabellas Core & FrontRunner - 2009 & $69 \%$ & $68 \%$ & $0 \%$ & $31 \%$ & $32 \%$ & $0 \%$ \\
\hline No Name 7353 & N/A & $74 \%$ & $69 \%$ & $-5 \%$ & $26 \%$ & $31 \%$ & $5 \%$ \\
\hline No Name 7151 & $\mathrm{~N} / \mathrm{A}$ & $91 \%$ & $83 \%$ & $-8 \%$ & $9 \%$ & $17 \%$ & $8 \%$ \\
\hline Murray & & $67 \%$ & $67 \%$ & $0 \%$ & $33 \%$ & $33 \%$ & $0 \%$ \\
\hline Murray & Blue Line - 2000 & $65 \%$ & $64 \%$ & $-1 \%$ & $35 \%$ & $36 \%$ & $1 \%$ \\
\hline Fireclay & Red Line - 2000 & $32 \%$ & $19 \%$ & $-13 \%$ & $68 \%$ & $81 \%$ & $13 \%$ \\
\hline Pleasant View & & $96 \%$ & $92 \%$ & $-4 \%$ & $4 \%$ & $8 \%$ & $4 \%$ \\
\hline Pleasant View & FrontRunner - 2009 & $94 \%$ & $86 \%$ & $-8 \%$ & $6 \%$ & $14 \%$ & $8 \%$ \\
\hline Salt Lake City & & $51 \%$ & $48 \%$ & $-3 \%$ & $49 \%$ & $52 \%$ & $3 \%$ \\
\hline Salt Lake Core & Blue, Red, Green - 2000-2008 & $24 \%$ & $24 \%$ & $0 \%$ & $76 \%$ & $76 \%$ & $0 \%$ \\
\hline LRT 1900 W North Temple & Green Line - 2013 & $34 \%$ & $32 \%$ & $-2 \%$ & $66 \%$ & $68 \%$ & $2 \%$ \\
\hline LRT 1500 W North Temple & Green Line - 2013 & $59 \%$ & $55 \%$ & $-4 \%$ & $41 \%$ & $45 \%$ & $4 \%$ \\
\hline LRT 825 W North Temple & Green Line - 2013 & $51 \%$ & $41 \%$ & $-9 \%$ & $49 \%$ & $59 \%$ & $9 \%$ \\
\hline LRT 1100 W North Temple & Green Line - 2013 & $61 \%$ & $54 \%$ & $-7 \%$ & $39 \%$ & $46 \%$ & $7 \%$ \\
\hline Sandy & & $84 \%$ & $80 \%$ & $-5 \%$ & $16 \%$ & $20 \%$ & $5 \%$ \\
\hline Sandy CBD & Blue Line - 2000, 2006 & $64 \%$ & $62 \%$ & $-2 \%$ & $36 \%$ & $38 \%$ & $2 \%$ \\
\hline South Jordan & & $90 \%$ & $85 \%$ & $-5 \%$ & $10 \%$ & $15 \%$ & $5 \%$ \\
\hline Daybreak & Red Line - 2011 & $96 \%$ & $89 \%$ & $-7 \%$ & $4 \%$ & $11 \%$ & $7 \%$ \\
\hline NoName 9875 & N/A & $79 \%$ & $77 \%$ & $-2 \%$ & $21 \%$ & $23 \%$ & $2 \%$ \\
\hline
\end{tabular}




\subsubsection{Transportation: Network}

Normalized data is easier to compare across urban centers since the land area varies drastically across centers. As a result, we focus on cul-de-sac ratio, average street length, bus stop density, bus route density and light rail stop density (see Figure 7-16).

The cul-de-sac ratio varies from 0.00 for centers with no cul-de-sac to 0.10 for centers with a higher level of cul-de-sacs, representing Fireclay. The numbers in all other centers vary from 0.00 to 0.10 with no clear trends emerging by city or rail line. NoName in Jordan had the highest ratio.

Average street length provides an indication of the size of blocks. A lower street length is a more walkable environment, while a longer street length is less walkable. Average street lengths range from 328 feet in Daybreak (South Jordan)) to 753 in 1400 S in Clearfield . Generally, street lengths are shorter on average in Salt Lake and first-tier suburbs like Aurora, and longer in newer suburbs like Lone Tree and Thornton.

The number of bus stops, bus routes and light rail gets at the availability of alternative modes in the center. It is important to note that although some of these centers have light rail stations adjacent to the center (like Cabellas' core and Layton,) the actual station area is outside of the urban center. The density of bus stops ranges from 0 in several stations to 50 at $825 \mathrm{~W}$ Temple in Salt Lake City. In general, the Salt Lake centers have a higher bus stop density, though Clearfield has high density too. The bus route trends are consistent with bus stops. Light rail stop density varies across centers from 0 in planned TODs or adjacent centers to 5.09 light rail stops per square mile. Most centers only have one light rail station with the exception of Salt Lake's core and Murray. 
Figure 7-16: Salt Lake Transportation Network for Select Centers, 2014

\begin{tabular}{|c|c|c|c|c|c|c|c|c|c|c|c|}
\hline Area & $\begin{array}{l}\text { Transit Line \& } \\
\text { Opening Date }\end{array}$ & $\begin{array}{l}\text { Number of } \\
\text { Cul-de-sacs }\end{array}$ & $\begin{array}{l}\text { Cul-de- } \\
\text { sac Ratio }\end{array}$ & $\begin{array}{l}\text { Length of } \\
\text { Streets (Ft) }\end{array}$ & $\begin{array}{l}\text { Average } \\
\text { Block } \\
\text { Lengths(Ft) }\end{array}$ & $\begin{array}{l}\text { Bus } \\
\text { stops }\end{array}$ & $\begin{array}{c}\text { Bus } \\
\text { Routes }\end{array}$ & $\begin{array}{l}\text { Light } \\
\text { Rail } \\
\text { Stops }\end{array}$ & $\begin{array}{l}\text { Bus } \\
\text { Stop } \\
\text { Density }\end{array}$ & $\begin{array}{l}\text { Bus } \\
\text { Route } \\
\text { Density }\end{array}$ & $\begin{array}{l}\text { Light } \\
\text { Rail } \\
\text { Stop } \\
\text { Density }\end{array}$ \\
\hline & & \multicolumn{10}{|c|}{2014 Static Data } \\
\hline \multicolumn{12}{|l|}{ Clearfield } \\
\hline $\begin{array}{l}\text { Layton } \\
\text { CRT } 1400 \text { S } 800 \text { E }\end{array}$ & $\begin{array}{l}\text { FrontRunner - } \\
2009 \\
\text { FrontRunner - } \\
2009\end{array}$ & 143 & 10.19 & 4,522 & 754 & 53 & 9 & 0 & $\begin{array}{l}14.10 \\
25.47\end{array}$ & $\begin{array}{l}2.39 \\
20.38\end{array}$ & 5.09 \\
\hline \multicolumn{12}{|l|}{ Lehi } \\
\hline Cabellas Core & $\begin{array}{l}\text { FrontRunner - } \\
2009\end{array}$ & 12 & 8.21 & 104,276 & 664 & 8 & 6 & 0 & 5.48 & 4.11 & - \\
\hline No Name 7353 & $\mathrm{~N} / \mathrm{A}$ & 8 & 40.76 & 10,549 & 377 & - & 0 & 0 & & & \\
\hline No Name 7151 & $\mathrm{~N} / \mathrm{A}$ & & 0.00 & 16,082 & 342 & - & 0 & 0 & & & \\
\hline \multicolumn{12}{|l|}{ Murray } \\
\hline Murray & Blue Line - 2000 & 46 & 21.31 & 210,411 & 440 & 38 & 7 & 2 & 17.61 & 3.24 & 0.93 \\
\hline Fireclay & Red Line - 2000 & 10 & 50.95 & 14,570 & 351 & 3 & 2 & 1 & 15.28 & 10.19 & 5.09 \\
\hline \multicolumn{12}{|l|}{ Pleasant View } \\
\hline Pleasant View & $\begin{array}{l}\text { FrontRunner - } \\
2009\end{array}$ & 15 & 32.26 & 19,106 & 390 & 6 & 2 & 1 & 12.90 & 4.30 & 2.15 \\
\hline \multicolumn{12}{|l|}{ Salt Lake City } \\
\hline Salt Lake Core & $\begin{array}{l}\text { Blue, Red, Green } \\
\text { - 2000-2008 } \\
\text { Green Line - }\end{array}$ & 118 & 23.10 & 492,737 & 441 & 196 & 37 & 15 & 38.38 & 7.24 & 2.94 \\
\hline LRT 1900 W North Temple & $\begin{array}{l}2013 \\
\text { Green Line - }\end{array}$ & 7 & 35.66 & 11,523 & 443 & 8 & 5 & 1 & 40.76 & 25.47 & 5.09 \\
\hline LRT 1500 W North Temple & $\begin{array}{l}2013 \\
\text { Green Line - }\end{array}$ & 6 & 30.57 & 11,165 & 346 & 5 & 4 & 1 & 25.47 & 20.38 & 5.09 \\
\hline LRT 825 W North Temple & $\begin{array}{l}2013 \\
\text { Green Line - }\end{array}$ & 5 & 25.47 & 22,610 & 435 & 10 & 6 & 1 & 50.95 & 30.57 & 5.09 \\
\hline LRT 1100 W North Temple & 2013 & 4 & 20.38 & 14,027 & 436 & 6 & 6 & 1 & 30.57 & 30.57 & 5.09 \\
\hline
\end{tabular}


Figure 7-16: (continued) Salt Lake Transportation Network for Select Centers, 2014

\begin{tabular}{|c|c|c|c|c|c|c|c|c|c|c|c|}
\hline Area & $\begin{array}{l}\text { Transit Line \& } \\
\text { Opening Date }\end{array}$ & $\begin{array}{l}\text { Number of } \\
\text { Cul-de-sacs }\end{array}$ & $\begin{array}{l}\text { Cul-de- } \\
\text { sac } \\
\text { Ratio }\end{array}$ & $\begin{array}{l}\text { Length of } \\
\text { Streets (Ft) }\end{array}$ & $\begin{array}{l}\text { Average } \\
\text { Block } \\
\text { Lengths(Ft) }\end{array}$ & $\begin{array}{l}\text { Bus } \\
\text { stops }\end{array}$ & $\begin{array}{l}\text { Bus } \\
\text { Routes }\end{array}$ & $\begin{array}{l}\text { Light } \\
\text { Rail } \\
\text { Stops }\end{array}$ & $\begin{array}{l}\text { Bus } \\
\text { Stop } \\
\text { Density }\end{array}$ & $\begin{array}{l}\text { Bus } \\
\text { Route } \\
\text { Density }\end{array}$ & $\begin{array}{l}\text { Light } \\
\text { Rail } \\
\text { Stop } \\
\text { Density }\end{array}$ \\
\hline & & \multicolumn{10}{|c|}{2014 Static Data } \\
\hline \multicolumn{12}{|l|}{ Sandy } \\
\hline Sandy CBD & $\begin{array}{l}\text { Blue Line - 2000, } \\
2006\end{array}$ & 47 & 20.04 & 169,655 & 447 & 33 & 8 & 3 & 14.07 & 3.41 & 1.28 \\
\hline \multicolumn{12}{|l|}{ South Jordan } \\
\hline Daybreak & Red Line - 2011 & 30 & 19.97 & 88,988 & 328 & 3 & 3 & 2 & 2.00 & 2.00 & 1.33 \\
\hline NoName 9875 & $\mathrm{~N} / \mathrm{A}$ & 13 & 66.23 & 15,177 & 391 & 5 & 2 & 0 & 25.47 & 10.19 & - \\
\hline
\end{tabular}




\subsubsection{Transportation: Transit Share}

As shown in Table 7-17, examining the mode split between 2000-2008-2012 provides interesting insights into trends within regions, cities and urban centers. At the regional level, there was no difference in the share of commuters using transit between 2000 and 2008-2012. Within cities, the share of transit increased from 0-2\%. Overall, the relative level of transit varies across cities. In Salt Lake 6\% use transit, but in Pleasant View, Lehi and Clearfield only 2\% use transit.

In examining trends by transit line, there are no observable trends by rail area or city as the results are variable within cities. Cities and centers were not always consistent with one another as far as transit share went, pointing to the high level of variability within cities.

Figure 7-17: Salt Lake Transit Share by Region, Cities and Select Centers, 2000-2008-2012

\begin{tabular}{|c|c|c|c|c|}
\hline \multirow{2}{*}{ Area } & \multirow{2}{*}{ Transit Line \& Opening Date } & \multicolumn{3}{|c|}{$\%$ Transit } \\
\hline & & 2000 & 2008-2012 & Diff. \\
\hline $\begin{array}{l}\text { WFRC Region (Box Elder, Davis, Morgan, } \\
\text { Salt Lake, Tooele, Weber Counties) }\end{array}$ & & $3 \%$ & $3 \%$ & $0 \%$ \\
\hline Clearfield & & $2 \%$ & $2 \%$ & $1 \%$ \\
\hline Layton & FrontRunner - 2009 & $3 \%$ & $2 \%$ & $0 \%$ \\
\hline CRT 1400 S $800 E$ & FrontRunner - 2009 & $2 \%$ & $0 \%$ & $-2 \%$ \\
\hline Lehi & & $2 \%$ & $2 \%$ & $0 \%$ \\
\hline Cabellas Core & FrontRunner - 2009 & $2 \%$ & $0 \%$ & $-2 \%$ \\
\hline No Name 7353 & $\mathrm{~N} / \mathrm{A}$ & $1 \%$ & $1 \%$ & $0 \%$ \\
\hline No Name 7151 & $\mathrm{~N} / \mathrm{A}$ & $2 \%$ & $2 \%$ & $0 \%$ \\
\hline Murray & & $4 \%$ & $3 \%$ & $-1 \%$ \\
\hline Murray & Blue Line - 2000 & $3 \%$ & $2 \%$ & $-1 \%$ \\
\hline Fireclay & Red Line - 2000 & $3 \%$ & $3 \%$ & $-1 \%$ \\
\hline Pleasant View & & $1 \%$ & $2 \%$ & $2 \%$ \\
\hline Pleasant View & FrontRunner - 2009 & $0 \%$ & $4 \%$ & $4 \%$ \\
\hline Salt Lake City & & $6 \%$ & $6 \%$ & $0 \%$ \\
\hline Salt Lake Core & Blue, Red, Green - 2000-2008 & $10 \%$ & $11 \%$ & $0 \%$ \\
\hline LRT 1900 W North Temple & Green Line - 2013 & $14 \%$ & $8 \%$ & $-5 \%$ \\
\hline LRT 1500 W North Temple & Green Line - 2013 & $10 \%$ & $1 \%$ & $-9 \%$ \\
\hline LRT 825 W North Temple & Green Line - 2013 & $11 \%$ & $9 \%$ & $-2 \%$ \\
\hline LRT 1100 W North Temple & Green Line - 2013 & $9 \%$ & $6 \%$ & $-3 \%$ \\
\hline Sandy & & $3 \%$ & $3 \%$ & $0 \%$ \\
\hline Sandy CBD & Blue Line - 2000, 2006 & $4 \%$ & $6 \%$ & $2 \%$ \\
\hline South Jordan & & $2 \%$ & $3 \%$ & $2 \%$ \\
\hline Daybreak & Red Line - 2011 & $0 \%$ & $2 \%$ & $2 \%$ \\
\hline NoName 9875 & $\mathrm{~N} / \mathrm{A}$ & $2 \%$ & $6 \%$ & $4 \%$ \\
\hline
\end{tabular}




\subsubsection{Transportation: Alternative Mode Share}

While trends in transit mode varied considerably, the share of bike, walk and transit trips combined increased pretty consistently across the region, cities and centers. More specifically, the regional share increased slightly, and other cities except Murray increased in alternative mode share. Lehi and Clearfield remained constant, while other cities increased between 0-2\%.

In looking at alternative mode share by transit line, the trends varied but some trends emerged. All of the stations on the Red and Blue lines (established earlier) increased in the share of alternative mode. The results were mixed for FrontRunner as several cities declined slightly. Many stations along the Green Line (opening in 2013) decreased significantly between 2000 and 2008-2012. Some centers declines as much as 14\% (825 W North Temple). Like transit share, cities and centers were not always consistent. Because most centers and cities increased these trends were consistent, but in Denver and Lakewood the picture was mixed. 
Figure 7-18: Salt Lake Alternative Mode Share by Region, Cities and Select Centers, 20002008-2012

\begin{tabular}{|c|c|c|c|c|}
\hline \multirow{2}{*}{ Area } & \multirow{2}{*}{ Transit Line \& Opening Date } & \multicolumn{3}{|c|}{$\%$ Bike Walk or Transit } \\
\hline & & 2000 & 2008-2012 & Diff. \\
\hline $\begin{array}{l}\text { WFRC Region (Box Elder, Davis, Morgan, } \\
\text { Salt Lake, Tooele, Weber Counties) }\end{array}$ & & $5 \%$ & $6 \%$ & $0 \%$ \\
\hline Clearfield & & $5 \%$ & $4 \%$ & $0 \%$ \\
\hline Layton & FrontRunner - 2009 & $4 \%$ & $5 \%$ & $1 \%$ \\
\hline CRT 1400 S $800 \mathrm{E}$ & FrontRunner - 2009 & $7 \%$ & $0 \%$ & $-6 \%$ \\
\hline Lehi & & $3 \%$ & $3 \%$ & $0 \%$ \\
\hline Cabellas Core & FrontRunner - 2009 & $2 \%$ & $1 \%$ & $-1 \%$ \\
\hline No Name 7353 & $N / A$ & $3 \%$ & $4 \%$ & $1 \%$ \\
\hline No Name 7151 & $\mathrm{~N} / \mathrm{A}$ & $2 \%$ & $4 \%$ & $2 \%$ \\
\hline Murray & & $7 \%$ & $6 \%$ & $-1 \%$ \\
\hline Murray & Blue Line - 2000 & $7 \%$ & $10 \%$ & $3 \%$ \\
\hline Fireclay & Red Line - 2000 & $6 \%$ & $10 \%$ & $4 \%$ \\
\hline Pleasant View & & $2 \%$ & $4 \%$ & $2 \%$ \\
\hline Pleasant View & FrontRunner - 2009 & $2 \%$ & $4 \%$ & $2 \%$ \\
\hline Salt Lake City & & $13 \%$ & $14 \%$ & $2 \%$ \\
\hline Salt Lake Core & Blue, Red, Green - 2000-2008 & $24 \%$ & $28 \%$ & $4 \%$ \\
\hline LRT 1900 W North Temple & Green Line - 2013 & $18 \%$ & $10 \%$ & $-8 \%$ \\
\hline LRT 1500 W North Temple & Green Line - 2013 & $13 \%$ & $1 \%$ & $-13 \%$ \\
\hline LRT 825 W North Temple & Green Line - 2013 & $26 \%$ & $12 \%$ & $-14 \%$ \\
\hline LRT 1100 W North Temple & Green Line - 2013 & $13 \%$ & $7 \%$ & $-6 \%$ \\
\hline Sandy & & $4 \%$ & $5 \%$ & $1 \%$ \\
\hline Sandy CBD & Blue Line - 2000, 2006 & $6 \%$ & $8 \%$ & $2 \%$ \\
\hline South Jordan & & $2 \%$ & $5 \%$ & $3 \%$ \\
\hline Daybreak & Red Line - 2011 & $0 \%$ & $2 \%$ & $2 \%$ \\
\hline NoName 9875 & N/A & $3 \%$ & $6 \%$ & $3 \%$ \\
\hline
\end{tabular}

\subsubsection{Transportation: Car Ownership}

Finally, we examined trends in car ownership focusing on the share of households with zero or one car, as shown in Figure 7-19. This serves as a proxy for households driving less, as VMT is not available at the center scale. We refer to these households as "low-car" households.

At the regional level, the share of households with one car or less declined by $1 \%$. At the city level, the results were mixed. Lehi and Pleasant View showed decreases in low-car households while Murray and Salt Lake did not change. Clearfield, Sandy and South Jordan saw slight increases in low-car households.

At the center level, the data was variable and inconclusive. Several centers saw very high increases in low-car households, which could represent centers attracting individuals who drive 
less. Several centers saw steep declines in the share of low-car households while other centers showed steep increases. The center with the steepest decline in low-car households was LRT 1900 W North Temple in Salt Lake at 10\%. Meanwhile, two centers in Lehi and one in Clearfield showed the steepest increases at around 9-10\%. It is important to note the vast range of values among centers. In some centers, only $9 \%$ of households are low-car while in other centers, $70 \%$ are low-car. The format of data made it very difficult to gather information like number of cars per household or understand the relationship between city sizes. As a result, we do not go into great depth about the data at the center level.

Figure 7-19: Salt Lake Car Ownership (Share 0 or 1) by Region, Cities and Select Centers, 2000-2008-2012

\begin{tabular}{|c|c|c|c|c|}
\hline \multirow{2}{*}{ Area } & \multirow{2}{*}{ Transit Line \& Opening Date } & \multicolumn{3}{|c|}{$\%$ Households with 0 or $1 \mathrm{Car}$} \\
\hline & & 2000 & 2008-2012 & Diff. \\
\hline $\begin{array}{l}\text { WFRC Region (Box Elder, Davis, Morgan, } \\
\text { Salt Lake, Tooele, Weber Counties) }\end{array}$ & & $33 \%$ & $32 \%$ & $-1 \%$ \\
\hline Clearfield & & $37 \%$ & $38 \%$ & $1 \%$ \\
\hline $\begin{array}{l}\text { Layton } \\
\text { CRT } 1400 \text { S } 800 E\end{array}$ & $\begin{array}{l}\text { FrontRunner - } 2009 \\
\text { FrontRunner - } 2009\end{array}$ & $\begin{array}{l}43 \% \\
60 \%\end{array}$ & $\begin{array}{l}42 \% \\
70 \%\end{array}$ & $\begin{array}{l}-1 \% \\
10 \%\end{array}$ \\
\hline Lehi & & $20 \%$ & $18 \%$ & $-2 \%$ \\
\hline $\begin{array}{l}\text { Cabellas Core } \\
\text { No Name } 7353 \\
\text { No Name } 7151 \\
\end{array}$ & $\begin{array}{l}\text { FrontRunner - } 2009 \\
\text { N/A } \\
\text { N/A }\end{array}$ & $\begin{array}{l}18 \% \\
26 \% \\
18 \% \\
\end{array}$ & $\begin{array}{l}32 \% \\
35 \% \\
10 \% \\
\end{array}$ & $\begin{array}{l}14 \% \\
10 \% \\
-7 \% \\
\end{array}$ \\
\hline Murray & & $40 \%$ & $40 \%$ & $0 \%$ \\
\hline $\begin{array}{l}\text { Murray } \\
\text { Fireclay }\end{array}$ & $\begin{array}{l}\text { Blue Line - } 2000 \\
\text { Red Line - } 2000\end{array}$ & $\begin{array}{l}39 \% \\
73 \%\end{array}$ & $\begin{array}{l}43 \% \\
64 \%\end{array}$ & $\begin{array}{r}4 \% \\
-9 \%\end{array}$ \\
\hline Pleasant View & & $19 \%$ & $15 \%$ & $-3 \%$ \\
\hline Pleasant View & FrontRunner - 2009 & $28 \%$ & $22 \%$ & $-6 \%$ \\
\hline Salt Lake City & & $53 \%$ & $53 \%$ & $0 \%$ \\
\hline $\begin{array}{l}\text { Salt Lake Core } \\
\text { LRT } 1900 \text { W North Temple } \\
\text { LRT } 1500 \text { W North Temple } \\
\text { LRT } 825 \text { W North Temple } \\
\text { LRT } 1100 \text { W North Temple }\end{array}$ & $\begin{array}{l}\text { Blue, Red, Green - 2000-2008 } \\
\text { Green Line - } 2013 \\
\text { Green Line - } 2013 \\
\text { Green Line - } 2013 \\
\text { Green Line - } 2013\end{array}$ & $\begin{array}{l}72 \% \\
61 \% \\
65 \% \\
48 \% \\
47 \% \\
\end{array}$ & $\begin{array}{l}72 \% \\
51 \% \\
62 \% \\
42 \% \\
39 \% \\
\end{array}$ & $\begin{array}{r}0 \% \\
-10 \% \\
-3 \% \\
-6 \% \\
-7 \% \\
\end{array}$ \\
\hline Sandy & & $20 \%$ & $23 \%$ & $2 \%$ \\
\hline Sandy CBD & Blue Line - 2000, 2006 & $36 \%$ & $38 \%$ & $2 \%$ \\
\hline South Jordan & & $15 \%$ & $17 \%$ & $2 \%$ \\
\hline $\begin{array}{l}\text { Daybreak } \\
\text { NoName } 9875\end{array}$ & $\begin{array}{l}\text { Red Line - } 2011 \\
\text { N/A }\end{array}$ & $\begin{array}{r}7 \% \\
28 \% \\
\end{array}$ & $\begin{array}{r}9 \% \\
34 \% \\
\end{array}$ & $\begin{array}{l}3 \% \\
7 \%\end{array}$ \\
\hline
\end{tabular}




\subsubsection{Synthesis of Salt Lake}

This section conveyed changes in demographic, land use and transportation metrics from 2000 to 2010 (or 2008-2012.) During this period the country experienced the Great Recession, affecting the economy; while Salt Lake expanded the transit network population grew by $18 \%$. We only examined a subset of centers by transit line and city, thus we caution drawing generalizations by transit line or city. In synthesizing information across indicators, some trends emerge.

In the Salt Lake region, suburbs are growing much faster than the city of Salt Lake and this is reflected in population, density, and housing unit data at the city and center scale. Centers are growing fast with some rare exceptions in Salt Lake City. In Salt Lake, these same centers saw increases in household income, declines in transit ridership and declines in the share of low-car households, perhaps signifying trends in gentrification like some centers in Denver.

In examining trends by transit line, the trends are less clear than Denver. However, population and housing growth tended to be stronger for FrontRunner, planned and Red and Blue lines stations. The Green Line (to the airport) just opened in 2013, several Green Line stations showed declines in population and some showed declines in housing units.

The impact of the recession seemed to be less significant in Salt Lake as trends in income and vacancy rates are more mixed in Salt Lake. While city-level income declined, center-level income increased in several cities. Centers in Lehi, South Jordan and Salt Lake all increased in median income, even during the recession.

The share of renters increased consistently in Salt Lake at the center level. While Clearfield and Murray changed little, all other cities saw increases in the share of renters as well.

The trends in transportation data are less clear. Several centers show a decline in transit and alternative mode share despite new transit stations opening. This was true in Clearfield, Lehi, Murray and Salt Lake. In Salt Lake, however, the stations showing declines were along the Green Line, which did not open until 2013. The trends in mode share were relatively consistent, though Murray saw increases in total alternative mode share despite a drop in transit mode split, indicating increases in biking and walking. Data for low-car households was similarly inconclusive. Several centers saw a decrease in low-car households including all centers in Salt Lake, Layton (Clearfield), NoName 7151 (Lehi), Fireclay (Murray) and Pleasant View.

These trends tell an interesting story. Across the region, many centers saw increases in population, households, income and renters. Nevertheless, these demographic and land use shifts were not coupled with similar increases in transit ridership, alternative modes, or low-car households. The influence of the recession creates noise in the data. Some centers tend to show signs of gentrification through these data, but several stations show positive trends towards the goals desired by WFRC. Across many centers, population and housing units are increasing faster than the regional or city average. In some centers, transit ridership and alternative mode shares are growing. Additionally, there has been an increase in renters in several centers, trending towards greater balance in renters and owners and indicating a mix of housing types. 


\subsection{IMPLICATIONS}

This study examines the role of voluntary regional planning in two rapidly growing metropolitan regions. One goal of this study was to assess the impact that regional collaboration has been having on local planning and its impact on development and land use patterns of metropolitan centers. A second goal is to identify the lessons and implications for the regional agencies in Denver and Salt Lake City, and for other regions working to develop and implement a regional vision strategy. In this section, we summarize the key findings and themes from this research and discuss some of the recommendations and transferable lessons.

\subsection{Summary of Key Findings}

\subsubsection{Adoption of the Centers Concept}

Across both regions, there is increasing use of the concept of centers (including urban centers and transit-oriented development). This has been particularly evident in our evaluation of plans in the Denver metropolitan region, which has included the concept as part of its regional plan since 2000 and included it in its transportation funding criteria since 2008. In the Salt Lake City area, a regional vision of centers did not emerge until 2005, did not appear in plans until 2010, and was not part of transportation funding criteria until 2015. This slower pace of adoption may also be reflected by fewer communities with multiple generations of comprehensive plans.

For communities that have adopted centers concepts, there has been an evolution in the vision of many of these centers over time. They have evolved from centers of single-use activity (employment, retail) to mixed-use centers offering more urban amenities. This evolution is occurring more quickly in some cities than others and, in general, the cities in the Denver region are further along than the Salt Lake City region. In some key locations, these plan changes allow higher density and a greater mix of uses that help achieve some of the center goals, but many simply reflect areas with already-existing density and single uses such as housing or retail.

There is no clear evidence that regional plans themselves have had a significant influence on local adoption of centers. There is very little reference to the regional visions, policies and plans, and planners indicated it was not a significant factor in changing local government planning because the centers themselves were identified and nominated by local governments. This is not to say that the idea, goals and objectives of centers have not indirectly influenced local planning ideas and concepts, but there is not clear evidence of this from the plans and interviews.

In some Denver area cities, planners indicated that transportation funding incentives have been a factor in considering the adoption of new centers. However, the small percentage of points allocated to center criteria, the large area of many centers and large number of centers across the metropolitan region all tend to reduce the relative importance of this criteria.

In many jurisdictions, market forces and transit investment were two key factors in leading municipalities to adopt centers and policies to support center development. This was particularly notable in some suburban communities that have recognized that they have relatively few highdensity, mixed-use centers in their jurisdiction and have sought to develop them to capture this market demand. In particular, many communities cite the goal of capturing investment from the emerging Millennial housing market and tech sector. For many jurisdictions, transit investment is 
the important catalyst to initiate this transformation, although some planners argued this could occur in areas without transit.

\subsubsection{Center Concepts Have Suffered From Vague Concepts and Criteria}

In both regions, centers are seen as a policy to promote an urban form that can increase housing choices, increase transit use, reduce vehicle miles travelled and create new centers for employment. The Denver Metro Vision has linked several of its regional performance indicators to this strategy.

However, the definition of centers in both regions is vague. Some are well-defined areas adjacent to transit, which could be anticipated to attract new development. For these sites, there exists-or is a potential for-a walkable area close to transit. Other centers are greenfield sites with some potential for new forms of development, but it's not always clear from city plans or policies that the results will achieve regional goals. There are also centers that encompass large areas, rural sites or locations that seem to have little potential to achieve regional goals.

Planner interviews also supported the finding that the designation of centers from the bottom up in both regions has created highly varied interpretations of what constitutes a center. There are no clear criteria for denying, constraining or re-visioning centers, which tends to dilute the policies meant to support them. For example, some planners indicated that the motivation to designate centers was to improve the ranking of transportation projects located near centers.

\subsubsection{The Adoption of Transit-Oriented Development Concept}

In both metropolitan regions, centers have been a generic term for areas of existing or anticipated higher-density growth. However, as noted above, the concept of centers is vague with unclear criteria. Some centers and TODs coincide. However, many centers extend far beyond the boundaries of a TOD, include multiple TODs or are large, undeveloped areas.

In our analysis of local plans, we found that the TOD concept has been adopted by cities across both regions, and the related plans and policies are far more specific and detailed. TOD concepts are accompanied by special area plans, special zoning codes and TOD districts, and specific financing tools. These areas have also seen some of the most significant private and public investment. Furthermore, planners indicated that grants from the regional agencies and transit agencies have been critical for accelerating TOD planning and development work.

\subsubsection{Barriers to Center Development}

Our plan analysis, planner interviews and spatial analysis have all revealed some significant barriers to the development of centers and their related regional objectives. In fact, the centers and stations in many cities are located in the areas with some of the fewest urban amenities.

First, many centers correspond with light rail lines that were located along existing highway and railroad rights-of-way. As a result, many centers are spliced by massive road or rail corridors that create significant barriers to bike and pedestrian movement.

Second, because of these rail lines and highways, many of the land uses along these corridors are industrial, office parks or big box retail. These uses are particularly hard to transform into a 
mixed-use, pedestrian-oriented center. The transformation also requires significant public investment.

Third, many of the suburban centers encompass areas with land uses and street patterns that offer poor connectivity and walkability. Even in areas where housing may be located in proximity to center amenities such as neighborhood services or transit, the bike or pedestrian pathway requires a long, circuitous route through a "loops and lollipops” subdivision.

Finally, many of the suburban centers yield lower rents for housing, office and retail, which means that lower-density development with surface parking is more likely to be the marketdriven outcome. Achieving a higher-density, compact center requires structured parking —which must often be provided by the public sector.

\subsection{Leading and Lagging Adopters}

The concept of centers is emerging in Salt Lake City and Denver, but it is apparent in both regions that there are local government leaders and laggards in the adoption of the concept. Based on our analysis, we grouped cities into three distinct categories based on their response to centers concepts and their discussion of centers in local planning documents: 1) Leading Adopters; 2) Delayed Adopters; and 3) Lagging Adopters.

Among the leader communities, the concept of centers has been incorporated into comprehensive plans, elected officials support the concept, and many see it as a critical policy for the future of their city. These communities adopted the concept of centers during their development or soon after they emerged at the regional level. Some of these communities specifically cited the regional metropolitan visioning process as a foundation for this concept. Delayed adopters are communities, which did not immediately take up centers concepts but did so in later planning efforts. These are distinct from lagging adopters, which have made minimal efforts toward centers adoption or else primarily see centers as a tool for securing regional TIP funding.

\subsubsection{Leading Adopters}

The plan analysis revealed that Denver and Aurora were the earliest adopters of the centers concept, embracing centers as they first emerged at the regional level.

The city of Aurora began incorporating centers concepts almost simultaneous to their adoption at the regional level. In its 1998 Comprehensive Plan, the city of Aurora emphasized its commitment to Metro Vision 2020. In the 2009 Comprehensive Plan, this commitment had increased significantly. This is illustrated by the search term "urban center" which was mentioned just once in the 1998 plan. In the 2009 Aurora Comprehensive Plan, there were numerous mentions of program and policy implementation related directly to urban centers:

"Create unique urban centers and public places in each of the distinct areas that reinforce the distinguishing characteristics of those areas” - Strategy 2 in Chapter IV Section A under Development in the Established City. 
"Coordinate with Colorado Community College to help ensure their campus redevelopment master plan is implemented and the area is designated as an urban center." -Strategy 4 in Chapter V Section F -under Redevelopment.

Aurora also adopted a new set of urban street standards in 2007 that were developed to encourage dense, walkable, mixed-use areas near transit stations. Interviews revealed that support for centers advanced as community leaders saw that rail passenger service was on the horizon. Anticipating that centers would eventually be a part of DRCOG's criteria for receiving federal transportation dollars, civic leaders sought to incorporate the principles of Metro Vision during the early stages of its development. In addition to this, leaders in Aurora saw centers as an opportunity to spur development around growing employment centers like the Anschutz Medical Campus. Urban centers, and later transit stations, were seen as opportunities to attract the middle and high-end residential housing missing in Aurora.

The city of Denver is another noted early adopter of centers policy. As early as the 1989 Denver Comprehensive Plan, the definition of "employment centers" had advanced beyond the singleuse campus development commonly found in other communities. At this early time, Denver already emphasized the need for mixed-use development and a high degree of transit access in its employment centers. The 2000 Denver Comprehensive Plan showed even more support for centers policy with a lengthy discussion on the implementation of "urban centers" and specific calls to "lead in supporting the adoption and implementation of DRCOG's Metro Vision 2020 Plan for regional growth...” (DRCOG, 2000, 246).

It is important to note that Denver followed a somewhat unique path in its decision to embrace the centers concept. Blueprint Denver, designed as a supplement to the 2000 Denver Comprehensive Plan and released in 2002, focuses on channeling the majority of new development to "areas of change" while maintaining the character of established "areas of stability." While the emphasis of "areas of change" is namely on neighborhood rehabilitation, there is considerable overlap with the goals expressed as part of DRCOG's centers concept. Moreover, the city of Denver has strategically located many of its designated centers in "areas of change” as a way to help leverage redevelopment in these key areas.

As with Denver, Salt Lake City was naturally poised to leverage the centers-based approach in the Wasatch Choice Vision. In addition to the obvious edge of having the Vision's only "metropolitan center" centered on downtown, the city has by far the most light rail, streetcar, and commuter rail station areas to use as a fulcrum for future development. The city's embrace of these opportunities is evident in the Transit Station Area District zoning the city has put in place for the one-eighth to one-quarter mile corridors surrounding the light rail corridors running east and west from downtown (400 South and North Temple streets) (Salt Lake City Code 21A.26.078) and the Form-Based Urban Neighborhood District the city has adopted for the light rail corridor going south from downtown (Salt Lake City Code 21A.27.050). The adoption of center principles is less strong in their general plan than in some of their local area plans. For example, the plan for the Sugar House neighborhood capitalizes on the streetcar corridor to create two new master plans for higher-density, mixed-use development incorporating over 4,000 new housing units and significant new retail and offices. 
Figure 8-1: Salt Lake City Transit Station Area District zoning

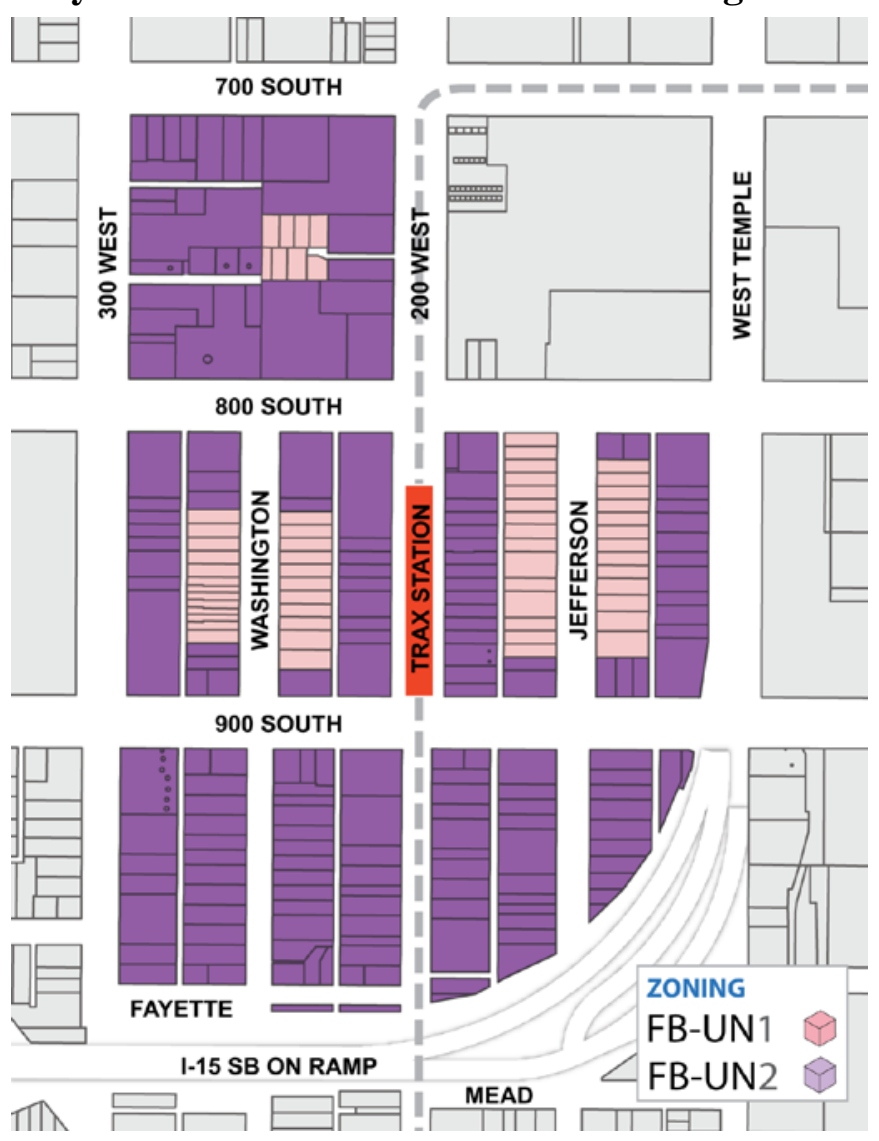

Source: Form Based Urban Neighborhood District Zoning Map. Salt Lake City.

\subsubsection{Delayed Adopters}

Delayed adopters are communities, which did not immediately take up centers concepts but did so in later planning efforts. For example, after a slow start, the city of Westminster began focusing more of its planning work on areas around designated centers. In Westminster's 1997 Comprehensive Plan, the only term to score above a 1 is "employment center." Even then, the definition used for employment centers is largely single-use, campus-style development. The 2004 Westminster Comprehensive Plan shows a significant increase in the city's embrace of center concepts, including growth goals that align with the planned construction of the northwest rail line (B line). Since that time, the city has made a significant shift towards embracing the centers concept. It has created specific area plans for designated areas (often co-located with transit stations) that include new zoning and development regulations. While development in other parts of the city must go through a more complicated planned-unit development approval process, developments within areas covered by a specific area plan have more assurance about permissible development and a streamlined process.

In the Salt Lake City region, the plans for the city of South Jordan have evolved from very little recognition of center-related concepts in its 1995 and 2005 plans to several significant centerrelated policy elements. However, by its 2010 plan it had made significant changes to policies related to transit-oriented development and town centers. The adoption of these policies coincide 
with the opening of commuter rail and light rail stations and market demand for different forms of housing. In particular, a new urbanist community called Daybreak opened in 2004 in conjunction with two new TRAX (light rail) stations.

\subsubsection{Lagging Adopters}

Lagging adopters are cities, which have made minimal efforts toward centers adoption or else primarily see centers as a tool for securing regional TIP funding.

In the Denver region, the city of Thornton serves as the clearest example of a lagging adopter. While Thornton's comprehensive planning documents reveal movement towards implementing centers, adoption is taking place more slowly than in other case study communities (see plan evaluations). Furthermore, despite the fact that Thornton has formally designated four urban centers, two (Thornton City Center and I-25/ Highway 7) are located in areas with low potential of developing into true mixed-use, walkable centers. Interviews revealed that the city designated these centers mainly as a means to obtain TIP funding and that community leaders feel that DRCOG's centers definition does not fit Thornton's suburban context.

In the Salt Lake City region, Clearfield is an example that has been slow to pick up on centerrelated concepts. It is primarily a suburban city located on the outer ring of urban development in the region. It has one FrontRunner station that opened in 2008 with over 500 park and ride spaces and no future plans for TRAX stations. In response to new transit it has developed TOD policies, but the city is dominated by single-use, low-density development.

\subsubsection{Summary of Key Spatial Findings}

Spatial analysis revealed interesting but inconclusive findings. The recession coupled with rapid expansion of transit that did not match with Census data muddied the analysis. Further, it is difficult to produce small area estimates using Census data when the center boundaries do not match Census geographies. Furthermore, local information about specific centers often revealed a lag period with property development as it went through purchase, demolition and redevelopment phases. Despite limitations, analysis revealed interesting trends.

Key findings are as follows:

- Most centers saw increases in population and housing units. The centers that did not were in the central cities of Denver and Salt Lake.

- In Salt Lake, most of the population growth went to suburbs. In Denver, a large share went to the city of Denver and first-ring suburbs.

- In Denver, median income uniformly declined. In Salt Lake, the trends were mixed. While cities saw declines in median income, centers in Lehi, Salt Lake and South Jordan increased during the recession.

- The share of renters increased at the regional, city and center level with few exceptions. This could be a result of the recession or a trend toward a mix of housing units.

- Some centers show trends toward gentrification with declining population coupled with increases in housing units, income and ownership, likely due to condo development. 
- Transit seems to guide trends in demographics, land use and transportation in Denver, but the trends are less clear in Salt Lake.

- Transit lines that have been open longer generally show more significant increases in population, housing units and transit ridership.

- While transit and alternative mode share changed little at the regional scale, several centers showed increases in transit ridership. This trend was more pronounced in Denver than Salt Lake.

Additional indicators would improve understanding of the trends seen in data collected to date. Further, data representing 2015 would be more revealing than 2010 Census data or 2008-2012 Census data.

\subsection{Recommendations and Transferable Lessons}

One of the goals of this research is to assess the impact that regional plans and policies have had on local planning and development. Another goal is to identify findings that provide recommendations to agencies and local governments in our two case study regions, as well as the lessons that are transferrable to other metropolitan regions. In particular, we consider regions that may not be experiencing the same kind of investment in transit infrastructure.

\subsubsection{Centers versus Mixed-Use Centers}

The concept of urban centers has played a prominent role in the regional visioning process for both Denver and Salt Lake City. The concept has been promoted in the Denver region since the 2000 Metro Vision Plan and supported by regional transportation funding incentives since 2008. In the Salt Lake City region, the concept did not appear until the 2010 Wasatch Choice Plan and transportation incentives were not incorporated until the 2015 regional transportation plan.

We found that the Metro Vision centers policy in Denver has not been a significant factor in local planning for several reasons. First, the concept and criteria of centers lacks specificity and clear criteria. In many cases, centers simply capture large areas of existing higher-density development or areas of undeveloped land. This may allow centers to meet the goals of capturing higher amounts of new employment and residential development, but it's not clear this policy will achieve other goals such as reduced vehicle miles travelled unless there is new transit investment that could shift mode share. Even with transit investment, the conditions existing at many station areas may generate nothing more than park-and-ride centers for those that do not attract new investment. In the Salt Lake City region, there are few clear policies defining regional centers, no measureable objectives and no evaluation criteria.

Second, the plans and planners indicated that centers have not significantly changed the plans of local jurisdictions. The centers are not identified or imposed by DRCOG, but rather proposed by the local jurisdiction and incorporated into the regional plan. Local governments are involved in nominating centers in the Denver region and the region has never rejected a center nomination. In the Salt Lake City region, centers are simply points on a regional map without defined boundaries. 
Third, there is an important difference between the regionally identified centers and the new mixed-use, amenity-based developments that are largely focused around transit. Many cities have adopted plans, policies and zoning codes that support mixed-use, higher-density development located adjacent to transit. These areas are experiencing most of the development interest and are likely to have the most benefits for regional transportation. However, it is not clear that these same development patterns and benefits will extend across the large regional centers. This is exemplified by the vast I-25 metropolitan center that encompasses Centennial, Greenwood, Denver and Lone Tree. As highlighted by Figure 8-1, this urban center incorporates three different light rail transit stations, each with the potential to emerge as transit-oriented development areas. However, the impact on the broader center area is questionable-particularly given that significant areas are already developed. A number of cities in both regions have developed new zoning and policies to support TOD, but other centers seemed to have produced little policy change. 
Figure 8-2: I-25 Urban Center

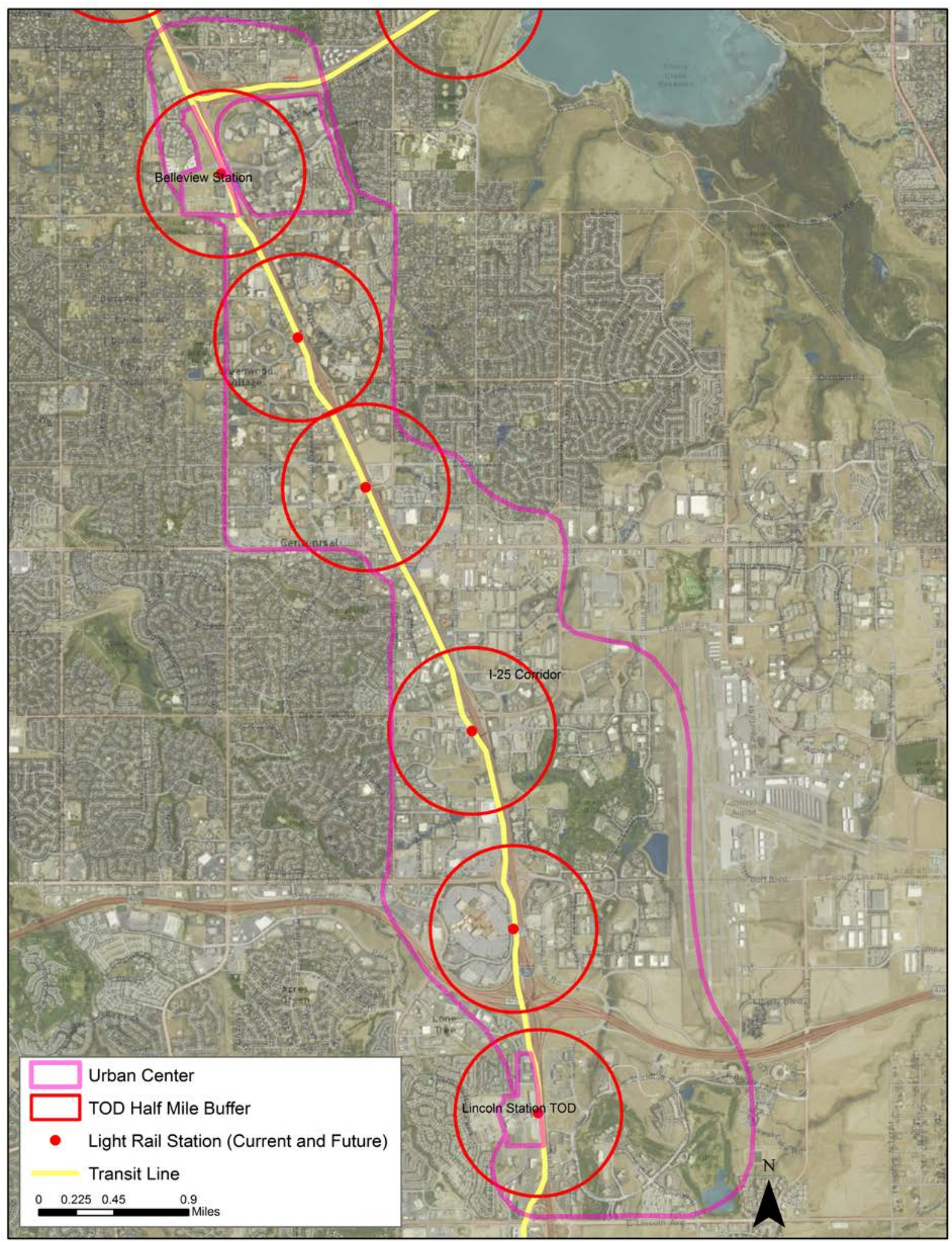


In contrast, a number of centers coincide with the concepts and criteria of transit-oriented development (see Figure 8-2). This form of urban development is likely to have the most significant impact on regional indicators such as transit use, vehicle miles traveled and housing options. Regions perusing policies to support centers would benefit from more strict definitions and tighter criteria for approving centers. This would also serve to focus funding incentives and grant programs into areas likely to have the best regional outcomes.

\section{Figure 8-3: Colorado Station Center}

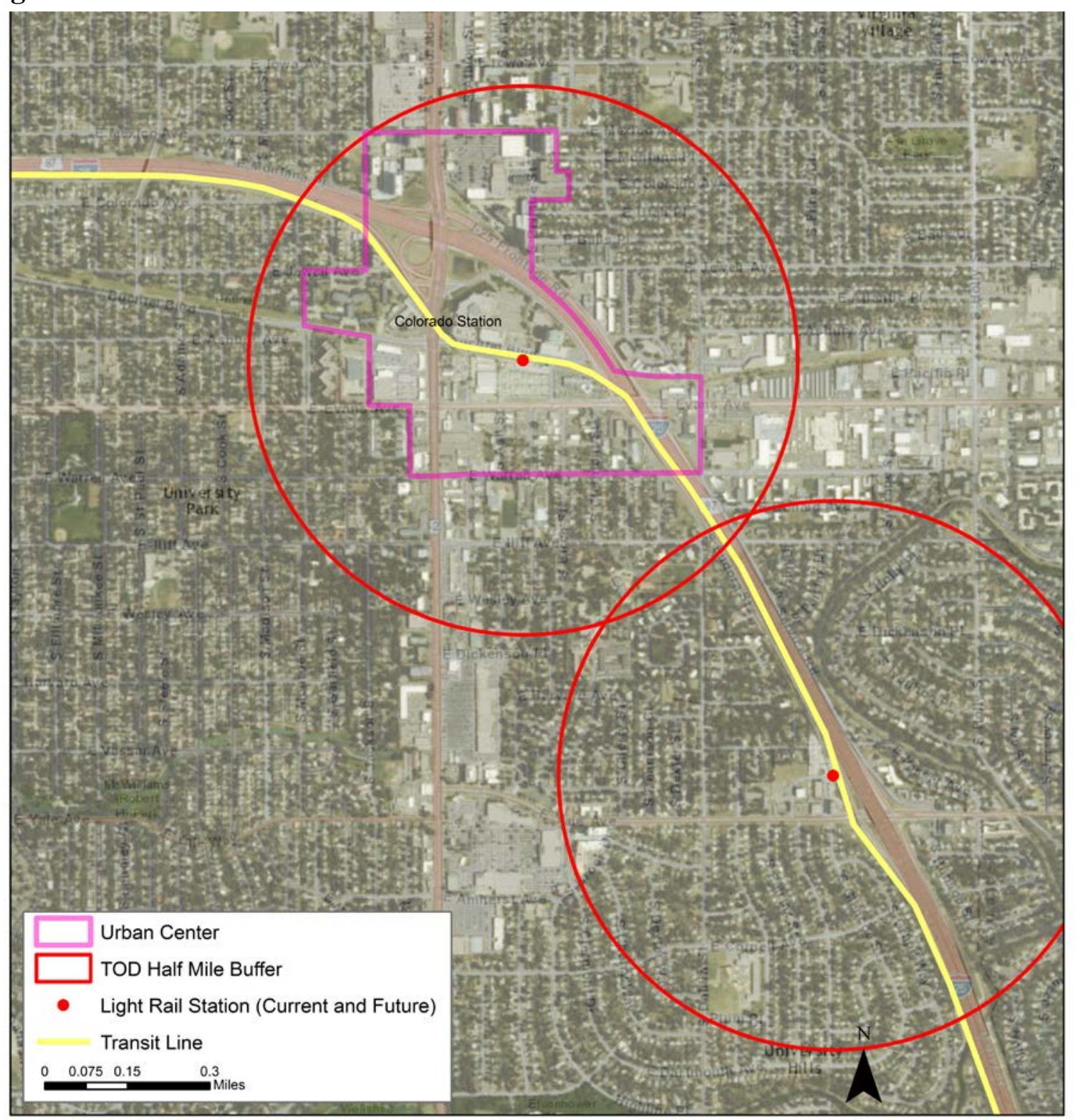

Importantly, these more narrowly defined centers may not require fixed transit (light rail, commuter rail). Chatman $(2013,29)$ suggests that "denser housing developments coupled with good management of automobile parking could reduce auto use in many contexts, and there could be a substantial market for it." Some of the planners interviewed for this study contended 
that transit investment was a catalyst for substantial public investment, which in turn stimulated private investment. However, they also speculated that significant public investment in places without the transit investment might also trigger private investment. While many people are attracted to TODs, people are also attracted to the urban lifestyle, walkable environment and urban amenities_-rather than the transit itself.

\subsubsection{Regional Incentives}

Most planners indicated that the incentives created through the regional Transportation Improvement Program are too small to have a significant impact on local government decision making. In some jurisdictions, the incentive was an added argument on top of grants, sales tax revenue and regional policy, but market forces and the investment in light rail were far more important factors. While figures from DRCOG indicate that a significant percentage of funded transportation projects received urban center points in the project ranking process, the large size and amorphous nature of centers dilutes the impact of this policy. In the Salt Lake City region, these incentives have been in place for a shorter period of time and there is less evidence about the impacts this has had on local planning.

In contrast, many jurisdictions in Denver have indicated that grants for planning around station areas has been important for moving their efforts forward. The grants have not changed council policy or direction, but they have allowed cities to determine how station areas can be redeveloped over time, what infrastructure needs will support this development, and how pedestrian and bike networks can be improved to support transit.

The most significant challenge facing jurisdictions in both Denver and Salt Lake City is the substantial capital investment required to support station area development. As noted above, many stations are located in areas that are not well suited for mixed-use development and therefore require substantial improvements to road, bike and pedestrian infrastructure. Many cities have recognized that redevelopment will require city leadership through land purchase, land assembly or public investment in structured parking. In many jurisdictions, market conditions make private mixed-use development more risky, and this public investment is often critical for transforming station areas. Furthermore, the large number of rail stations being developed in Denver means that there is competition for development at many centers, and those with greater momentum (via private or public investment) are most likely to emerge as the winners.

\subsubsection{Centers and Existing Characteristics}

Many of the centers designated in our two case study regions were in response to the development of new rail and light rail lines. The right-of-way costs to construct these lines is considerable, and thus there are often compromises in location decisions. As a result, many lines and stations are located along existing rail lines and highways, which tend to create significant barriers to mobility and redevelopment. However, these location decisions have a long and lasting impact on the potential of these centers to develop over the long term. Some of the key characteristics that are likely to limit center development include:

- Centers with significant rail and highway barriers that reduce local area non-vehicle mobility (walking and biking) 
- Street patterns and networks that limit connectivity near centers (dead-end streets; cul-desacs)

- An urban form consisting of industrial, warehouse or big box retail, which make it difficult to convert into a more pedestrian-oriented amenity center

- An area that lacks amenities (parks, open space) or existing commercial development (retail, restaurants, coffee shops) that would attract high-density development

- Areas that have low rents, which tend to lead to developments with lower density and surface parking

In examining the centers related to new transit stations, we identified three general types of stations that present different opportunities and challenges:

- Tipping point centers: Areas of existing density and amenities where the addition of transit access accelerates change and existing market forces. These are the areas likely to develop most quickly with the least amount of public-sector investment or changes in local plans and codes.

- Redevelopment centers: Areas with existing uses (industrial, commercial, office) that have the potential for future transformation, but will require a significant change in urban form and infrastructure. These areas will often require substantial public investment to transform the land use and improve bike, pedestrian and transit access. Many of these areas may evolve as either park and rides or development adjacent to transit without public investment.

- Greenfield centers: Areas with large areas of undeveloped land that offer a potential for the emergence of new mixed-use, transit-oriented development centers. These areas also require public investment in infrastructure, and their suburban location may require public investment in facilities such as structured parking to encourage higher-density development. Planning and zoning codes may play an important role in setting development standards, minimum densities and other policies to support these centers.

In metropolitan regions considering a regional strategy promoting centers, it is important to examine the different types of strategies and public investment required to develop these centers. This applies also to regions promoting centers that is not linked to fixed transit, but supported by other transit or implemented to achieve other regional and local goals.

\subsubsection{Capitalizing on Market Forces}

Market forces are playing a significant role in driving new development in both metropolitan regions. The market demand includes: desire for a more urban living experience; access to amenities and services; multifamily housing; and access to transit. In many jurisdictions, these market forces have changed political attitudes towards higher-density development. However, these jurisdictions also face considerable challenges related to information, expertise, and strategies to engage communities that may resist higher density.

MPOs and other regional agencies may be able to capitalize on this trend by providing technical assistance to local communities. This may be assisted by regional agency staff, access to experts, or grants to support specialized studies. Some of the types of services that planners indicated would be useful for their efforts include: 
- Providing analysis and evaluation of market demands

- Working with developers and housing organizations to identify key factors and location conditions necessary to support investment

- Sharing case studies from other regions that highlight trends and projects

- Offering grants to support planning in locations likely to attract this kind of development

- Providing technical assistance to local communities in relation to plan development, model codes, financing, urban design and active transportation strategies

\subsubsection{Comparing the Roles of NGOs and MPOs}

In the literature on American regional governance, there is a distinction traditionally observed between the regions that have statutory/regulatory authority to require local government compliance with regional plans_-Portland and the Twin Cities—and the rest of the nation's 408 MPOs, which labor with only hortatory or indirect methods of inducing local compliance (e.g., Leo, 1998; Brenner, 2002). In our comparison of the Denver and Salt Lake regions, we perceive an additional distinction: Those regions in which concepts of regional form and future growth are engaged by non-governmental organizations (NGOs) and those in which the MPO takes initial leadership on these issues.

Implicit in the comparison of timelines between Denver and Salt Lake is the role that an NGOEnvision Utah—plays in the Salt Lake example. While both regions sourced their journey toward a centers-based regional plan in the mid-1990s, Denver area municipalities seem to have a 10-year lead on Salt Lake municipalities in incorporating the centers designations from the regional plan into local plans. Put differently, the Salt Lake municipalities are approximately where the Denver municipalities were 10 years ago. This despite the fact that the two regions initiated their respective public conversations about the use of a centers-based approach at approximately the same time.

Municipal leaders in Salt Lake were very much a part of the dialog leading up to the creation of the Quality Growth Strategy. Yet, general plans in the region did not start changing to reflect a centers approach until after the MPO's adoption of the Wasatch Choices Vision in 2010. It may very well be that local government leaders used the Quality Growth Strategy dialog not just as a way of becoming personally acquainted with centers-based planning approaches, but also as a method of testing constituent support. Once that support was sufficiently indicated it became politically feasible for them to endorse the approach, first through the MPO plan development and adoption process and then through planning processes in their own jurisdictions. But it seems that the MPO adoption step had to come before local incorporation, notwithstanding the political cover provided by the Quality Growth Strategy processes. It would seem, hence, that the NGO-phase of the dialog may have been a necessary, but not sufficient, step toward local policy adoption. Naturally, substantiating these claims requires more investigation, and with more than just two regions. Given the important roles that NGOs have played in other regional planning processes, including those in Orlando (MyRegion.org) and Austin (Envision Central Texas) (Bartholomew, 2005), the topic seems a potentially fruitful avenue for further inquiry. 


\subsection{REFERENCES}

1000 Friends of Oregon. (1992). The LUTRAQ Alternative. Portland, OR: 1000 Friends of Oregon.

1000 Friends of Oregon. (1997). Making the Connections - LUTRAQ Project Summary. Portland, OR: 1000 Friends of Oregon.

Administration, 28(13-14): 1057-1079.

Agranoff, R., \& McGuire, M. (2003). Collaborative Public Management. Washington D.C.: Georgetown University Press.

Alexander, M., \& Hamilton, K. (2015). A 'Placeful' Station? The Community Role in Place Making and Improving Hedonic Value at Local Railway Stations. Transportation Research Part A: Policy \& Practice 82: 65-77.

Allred, D., \& Chakraborty, A. (2015). Do Local Development Outcomes Follow Voluntary Regional Plans? Evidence From Sacramento Region’s Blueprint Plan. Journal of the American Planning Association, 81(2), 104-120. http://doi.org/10.1080/01944363.2015.1067574

American Association of State Highway Officials (AASHO). (1962). Freeways in the Urban Setting: Hershey Conference. Washington, DC: Automotive Safety Foundation.

Ansell, C., \& Gash, A. (2007). Collaborative Governance in Theory and Practice. Journal of Public Administration Research and Theory 18(4): 543-71.

Ansell, C., \& Gash, A. (2008). Collaborative Governance in Theory and Practice. Journal of Public Administration Research and Theory, 18(4), 543-571.

Ansell, C., \& Gash, A. (2008). Collaborative Governance in Theory and Practice. Journal of Public Administration Research and Theory 18 (4): 543-71.

Assessing One Slice of the Federal Marble Cake. Publius 32(1).

Barbour, E., \& Teitz, M. B. (2006). Blueprint Planning in California: Forging Consensus on Metropolitan Growth and Development (No. 9780262134927 (hardcover alk. paper) 0262134926 (hardcover alk. paper) 9780262512299 (pbk. alk. paper) 0262512297 (pbk. alk. paper)) (pp. 171-200). San Francisco, CA: Public Policy Institute of California.

Barbour, E., \& Teitz, M. B. (2009). Blueprint planning in California: An experiment in regional planning for sustainable development. In D. A. Mazmanian \& M. E. Kraft (Eds.), Toward sustainable communities : transition and transformations in environmental policy (2nd ed., pp. 171-200). Cambridge, MA: MIT Press.

Bartholomew, K. (2006). Metropolitan Utah: Making the Desert Bloom - with Ice Cream Parlors and Latte Stands, in Zick, C. \& Smith, K. (eds.), Utah at the Beginning of the New Millenium: A Demographic Perspective. Salt Lake City, UT: University of Utah Press.

Bartholomew, K. (2005). Integrating Land Use Issues into Transportation Planning: Scenario Planning Annotated Bibliography. Available at http://content.lib.utah.edu/cdm/ref/collection/uspace/id/338.

Bartholomew, K. (2010). Integrated Transportation Scenario Planning - Annotated Bibliography. Available at http://content.lib.utah.edu/cdm/ref/collection/uspace/id/274.

Bartholomew, K., \& Ewing, R. (2009). Land Use-Transportation Scenario Planning: A Meta-Analysis. Journal of the American Planning Association 75(1): 13-27.

Bartholomew, K. \& Ewing, R. (2016). Integrated Transportation Scenario Planning in the 21st Century. Transp Research Board Annual Meeting. 
Bartholomew, K. and R. Ewing (2010) Integrated Transportation Scenario Planning. Publication FHWA-HEP-10-034. Federal Highway Administration, U.S. Department of Transportation.

Bartholomew, K. Land Use-Transportation Scenario Planning: Promise and Reality. Transportation, Vol. 34, No. 4, 2007, pp. 397-412.

Benjamin, S.B., Kincaid, J., \& McDowell, B. (1994). MPOs and Weighted Voting. Intergovernmental Perspective 20(2): 31-35.

Boarnet, M. \& Compin, N. (2007). Transit-Oriented Development in San Diego County - The Incremental Implementation of a Planning Idea. Journal of the American Planning Association 65(1): 80-95.

Bollens, Scott A. July 92, 11. "State Growth Management: Intergovernmental Frameworks and Policy Objectives.” Journal of the American Planning Association 58 (4): 454-66.

Bone v. Lewiston. (1984). 107 Idaho 844; 693 P.2d 1046; 1984 Ida. LEXIS 590.

Bullard, R., Johnson, G. S., \& Torres, A. O. (2000). Sprawl City: Race, Politics, and Planning in Atlanta. Island Press.

Bureau of Public Roads. (1963). Urban Transportation Planning (Instructional Memorandum No. 50-263). Washington, DC: U.S. Dept. of Commerce.

Calthorpe, P. (1993). The Next American Metropolis: Ecology, Community, and the American Dream. New York: Princeton Architectural Press.

Cervero, R, \& Kockelman, K, (1997). Travel Demand and the 3ds: Density, Diversity, and Design. Transportation Research Part D: Transport and Environment 2(3): 199-219.

Cervero, Robert. "Growing Smart by Linking Transportation and Land Use: Perspectives from California." Built Environment 29, no. 1 (2003): 66-78.

Cervero, Robert. "Growing Smart by Linking Transportation and Land Use: Perspectives from California." Built Environment 29, no. 1 (2003): 66-78.

Chakraborty, A. (2010). Scenario Planning for Effective Regional Governance: Promises and Limitations. State and Local Government Review, 42(2), 156-167. http://doi.org/10.1177/0160323X10377344

Chapin, T. \& Connerly, C. (2004). Attitudes Towards Growth Management in Florida - Comparing Resident Support in 1985 and 2001. Journal of the American Planning Association 70(4): 443-452.

Chatman, D. G. (2013). Does TOD Need the T? Journal of the American Planning Association, 79(1), 17-31. http://doi.org/10.1080/01944363.2013.791008

City of Aurora (Colorado). (2009). Aurora Comprehensive Plan. Chapter IV. A. -Managing the Geography of Growth (Pg. 5). The City [2009].

City of Englewood (Colorado). (2003). Roadmap Englewood: 2003 Englewood Comprehensive Plan. The City [2003]

City of Greenwood Village. (2004). Greenwood Village Comprehensive Plan. The City [2004]. Updated in 2012.

City of Lakewood (Colorado). (2003). Lakewood Comprehensive Plan. The City [2003]

City of Lone Tree (Colorado). (2008). Lone Tree Comprehensive Plan. The City [2008].

City of Westminster (Colorado). (2004). Westminster Comprehensive Land Use Plan. The City [2004]. Updated in 2008.

Curtin, D.J. \& Talbert, C.T. (2005). California Land Use and Planning Law (25 ${ }^{\text {th }}$ ed.). Point Arena, CA: Solano Press.

Dawkins, C. \& Nelson, A.C. (2004). Urban Containment in the United States: History, Models, and Techniques for Regional and Metropolitan Growth Management. Chicago, IL: American Planning Association. 
DeGrove, John M. 1984. Land Growth and Politics. Chicago, Illinois: American Planning Association.

Denver Regional Council of Governments,. (2011, February 16). Metro Vision 2035 Plan. Denver CO: DRCOG.

Deyle, R.E. \& Wiedenman, R.E. (2014). Collaborative Planning by Metropolitan Planning Organizations: A Test of Causal Theory. Journal of Planning Education and Research 34(3): 257-275.

DRCOG. (2000). Metro Vision 2020 Plan (p. 58 pp.). Denver: Denver Regional Council of Governments.

DRCOG. (2007). 2035 Metro vision regional transportation plan. Denver, CO: Denver Regional Council of Governments. Retrieved from http:www.drcog.org/MVRC/socio.html

DRCOG. (2009). With one voice. Denver, CO: Denver Regional Council of Governments. Retrieved from http:www.drcog.org/MVRC/socio.html

DRCOG. (2010). Policy on transportation improvement program (TIP) preparation: Procedures for preparing the 2012-2017 TIP. Denver, CO: Denver Regional Council of Governments. Retrieved from http:www.drcog.org/MVRC/socio.html

DRCOG. (2011). Transportation planning in the Denver region. Denver, CO: Denver Regional Council of Governments.

DRCOG (2015). 2015 Budget. Denver CO: Denver Regional Council of Governments.

DRCOG (2016a). About DRCOG. Retrieved March 10, 2016, from https://www.drcog.org/aboutdrcog/about-drcog

DRCOG (2016b). Metro Vision. Retrieved March 10, 2016, from https://www.drcog.org/planning-greatregion/metro-vision

Edner, S. \& McDowell, B. (2002). Surface-Transportation Funding in a New Century: Assessing Once Slice of the Federal Marble Cake. Publius 32(1): 7-24.

Emerson, K., Nabatchi, T., \& Balogh, S. (2012). An integrative framework for collaborative governance. Journal of Public Administration Research and Theory, 22(1), 1-29.

Envision Utah. (n.d.). The History of Envision Utah. Salt Lake City, UT: Coalition for Utah's Future.

Eschweiler, P.Q. (1993). In Accordance with A Comprehensive Plan: The Need for Planning Consistency in New York State. Pace Environmental Law Review 10: 603-682.

Evensen, E. (1999). Open Space Preservation in Utah: Techniques, Tools, and First "Quality Growth" Steps. Journal of Land, Resources, and Environmental Law 19: 267-292.

Ewing, R. Research You Can Use: Regional Scenario Plans and Meta-Analysis. Planning, Vol. 73, No. 3, 2007, March, p. 38.

Ewing, R. \& Bartholomew, K. (2013). Pedestrian- and Transit-Oriented Design. Washington, DC: ULI.

Ewing, R., \& Cervero, R. (2010). Travel and the built environment: a meta-analysis. Journal of the American Planning Association, 76 (3), 265-294.

Federal Highway Administration (FHWA). (2004). 9th National Conference on Transportation Planning for Small \& Medium-Sized Communities, Colorado Springs, Colorado - Session 2: MPOs: Who, What and How, 22 September 2004, http://www.planning.dot.gov/Documents/TransPlanning/FHWA_MPO_Workshop.htm

Gale, Dennis E. 1992. "Eight State Sponsored Growth Management Programs: A Comparative Analysis.” Journal of the American Planning Association 58 (4): 425-39.

Goetz, A. (2013). Suburban Sprawl or Urban Centres: Tensions and Contradictions of Smart Growth Approaches in Denver, Colorado. Urban Studies, 50(11), 2178-2195. http://doi.org/10.1177/0042098013478238

Goetz, A.R., Dempsey, P.S., \& Larson, C. (2002). Metropolitan Planning Organizations: Findings and Recommendations for Improving Transportation Planning. Publius 32(1): 87-105. 
Goldman, T., \& Deakin, E. (2000). Regionalism through Partnerships? Metropolitan Planning Since ISTEA. Berkeley Planning Review 14: 46-75.

Gray, B. (1989). Collaborating: Finding Common Ground for Multiparty Problems. San Francisco, CA: Jossey-Bass.

Hamroun, Y.F. (2006). The Decision-Making Process in Metropolitan Planning Organizations. Master’s Thesis, University of Delaware.

Helling, A. (1998). Collaborative visioning: proceed with caution! Results from evaluating Atlanta's Vision 2020 project. Journal of the American Planning Association, 64(3), 335-349.

Hendricks, S.J., \& Seggerman, K. (2005). Incorporating Transportation Demand Management into the Land Development Process. Tampa, Florida: Center for Urban Transportation Research, University of South Florida.

Huxham, C., Vangen, S., Huxham, C., \& Eden, C. (2000). The Challenge of Collaborative Governance. Public Management: An International Journal of Research and Theory, 2(3), 337-358. http://doi.org/10.1080/14719030000000021

Innes, J. E. (1999). Evaluating Consensus Building. In L. Susskind, S. McKearnon, \& S. Carpenter (Eds.), Consensus Building Handbook: A Comprehensive Guide to Reaching Agreement (pp. 631-675). Thousand Oaks, CA: Sage.

Innes, J. E., \& Gruber, J. (2005). Planning Styles in Conflict: The Metropolitan Transportation Commission. Journal of the American Planning Association 71 (2): 177-88.

Innes, J. E., Gruber, J., Neuman, M., \& Thompson, R. (1994). Coordinating growth and environmental management through consensus building. Berkeley, CA: California Policy Seminar.

Innes, J., \& Booher, D. E. (1999). Metropolitan development as a complex system: a new approach to sustainability. Economic Development Quarterly, 13(2), 141-156.

Jonas, A. E. G., Goetz, A. R., \& Bhattacharjee, S. (2014a). City-regionalism as a Politics of Collective Provision: Regional Transport Infrastructure in Denver, USA. Urban Studies, 51(11), 2444-2465. http://doi.org/10.1177/0042098013493480

Jonas, A. E. G., Goetz, A. R., \& Bhattacharjee, S. (2014b). City-regionalism as a Politics of Collective Provision: Regional Transport Infrastructure in Denver, USA. Urban Studies, 51(11), 2444-2465. http://doi.org/10.1177/0042098013493480

K. Knapp, K.S. Rao, J.A. Crawford \& R.A. Krammes, Use and Evaluation of Transportation Control Measures (1994).

Kay, A. I., Noland, R. B., \& DiPetrillo, S. (2014). Residential Property Valuations Near Transit Stations with Transit-Oriented Development. Journal of Transport Geography 39: 131-140.

Kim, J.H., Cho, J., \& Keane, T.D. (2015). Political Fragmentation and Land Use Changes in the Interior Plains. Population and Environment 37(1, 2): 63-82.

Lewis, P. \& Baldassare, M. (2010). The Complexity of Public Attitudes toward Compact Development. Journal of the American Planning Association 76:2, pages 219-237.

Lewis, P.G. (1998). Regionalism and Representation: Measuring and Assessing Representation in Metropolitan Planning Organizations. Urban Affairs Review 33(6): 839-853.

Lewis, P.G. \& Sprague, M. (1997). Federal Transportation Policy and the Role of Metropolitan Planning Organizations in California. San Francisco: Pub. Policy Inst. of Cal.

Lim, G.C. (1983). Regional Planning. Totowa, NJ: Allanheld.

Lovelady, A. (2009). MPOS and the Integration of Transportation and Land Use Planning. Virginia Environmental Law Journal 27: 275-320.

Luna, M. (2015). Equity in Transportation Planning: An Analysis of the Boston Region Metropolitan Planning Organization. The Professional Geographer 67(2): 282-294. 
Margerum, R. D. (2005). Collaborative growth management in metropolitan Denver: "Fig leaf or valiant effort?” Land Use Policy, 22(4), 373-386.

Margerum, R. D. (2011). Beyond consensus: improving collaborative planning and management. Boston, MA: MIT Press.

Margerum, R. D., Brody, S., Parker, B., \& McEwen, G. (2011). Regional Transportation and Land Use Decision Making in Metropolitan Regions: Findings from Four Case Studies. Wasthington DC: Federal Highway Administration.

Margerum, R. D., Brody, S., Parker, R. and McEwen, G. (2011). Regional Transportation and Land Use Decision Making in Metropolitan Regions: Findings from Four Case Studies. https://scholarsbank.uoregon.edu/xmlui/bitstream/handle/1794/12161/MPO_Finalreport_Main_fina l.pdf

Margerum, R.D. (2002). Evaluating Collaborative Planning - Implications from an Empirical Analysis of Growth Management. Journal of the American Planning Association 68(2): 179-93.

McDowell, B.D. (1984). The Metropolitan Planning Organization Role in the 1980s. Journal of Advanced Transportation 18: 125- .

McGuire, M. (2006). Collaborative public management: assessing what we know and how we know it. Public Administration Review, 66(S1), 33-43.

Metro Mayors Caucas,. (n.d.). About MMC. Retrieved April 12, 2016, from http://www.metromayors.org/index.aspx?NID=89

Miller, J.S., Howe, R.W., Hartman, R.P., \& Goswami, A.K. (2004). Options for Improving the Coordination of Transportation and Land Use Planning in Virginia. Charlottesville, Virginia: Virginia Transportation Research Council.

Norris, D.F. (2001). Whither Metropolitan Governance? Urban Affairs Review 36: 532-550.

Olson, B.K. (2000). The Transportation Equity Act for the 21st Century: The Failure of Metropolitan Planning Organizations to Reform Federal Transportation Policy in Metropolitan Areas. Transportation Law Journal 28: 147-183.

Orfield, M. (2002). American Metropolitics. Washington, DC: Brookings Institution Press.

Pendall, R. (1999). Do Land-Use Controls Cause Sprawl? Environment and Planning B: Planning and Design 26: 555-371.

Planning Organizations under ISTEA and TEA-21. International Journal of Public

Regional Transportation District. (2015) Northwest Rail Line: 2015 Fact Sheet. http://www.rtdfastracks.com/media/uploads/nw/NWR_Fact_Sheet_rev_Jun_15.pdf

Regional Transportation District. (2015). North Metro Rail Line: 2015 Fact Sheet. http://www.rtdfastracks.com/media/uploads/nm/NM_Fact_Sheet_FINAL_2015.pdf

Regional Transportation District. (2015). Southeast Rail Extension: 2015 Fact Sheet. http://www.rtdfastracks.com/media/uploads/se/SERE_Fact_Sheet_FINAL_2015.pdf

Rodíguez, D.A, \& Godschalk, D.R.. (2003). The Connection between Land Use and Transportation in Land Use Plans. Raleigh, North Carolina: North Carolina Department of Transportation.

Sanchez, T. (2006). Inherent Bias? Geographic and Racial-Ethnic Patterns of Metropolitan Planning Organization Boards. Washington, DC: Brookings Institution.

Sciara, G., \& Handy, S. (2013). Cultivating Cooperation without Control: A Study of California's MPODriven Smart Growth Programs (UCD-ITS-RR-13-07. Davis, CA: Institute of Transportation Studies, UC Davis.

Social Explorer Tables: ACS 2014 (5-Year Estimates)(SE), ACS 2014 (5-Year Estimates), Social Explorer; U.S. Census Bureau (SE:T1 Total Population) 
Solof, M. (1997). History of Metropolitan Planning Organizations. Newark, NJ: North Jersey Transportation Planning Authority. Available at http://www.njtpa.org/public_affairs/mpo_history/MPOhistory1998.pdf.

Sullivan, E.J. (2014). Urban Growth Management in Portland, Oregon. Oregon Law Review 93: 455-498.

Sung, H., Choi, K., Lee, S., \& Cheon, S. (2014). Exploring the Impacts of Land Use by Service Coverage and Station-Level Accessibility on Rail Transit Ridership. Journal of Transport Geography 36: 134140.

Thomas, C. W., \& Koontz, T. M. (2011). Research designs for evaluating the impact of community-based management on natural resource conservation. Journal of Natural Resources Policy Research, 3(2), 97-111.

TransLink. (2010). Transit-Oriented Communities: A Literature Review on the Relationship between the Built Environment and Transit Ridership. Vancouver, BC: TransLink.

U.S. Advisory Commission on Intergovernmental Relations (ACIR). (1997). Planning Progress: Addressing ISTEA Requirements in Metropolitan Planning Areas. Washington, DC: U.S. Advisory Commission on Intergovernmental Relations.

U.S. Department of Commerce. (1926). A Standard State Zoning Enabling Act. Washington. DC: GPO.

U.S. Government Accounting Office (GAO). (2002). The Federal Government Could Help Communities Better Plan for Transportation That Protects Air Quality. Testimony before the Committee on Environment and Public Works, U.S. Senate.

Vogel, R.K., \& Nezelkewicz, N. (2002). Metropolitan Planning Organizations and the New Regionalism: The Case of Louisville. Publius 32(1): 107-129.

Waddell, P. (2002). UrbanSim: Modeling Urban Development for Land Use, Transportation and Environmental Planning. Journal of the American Planning Association 68(3): 297-314.

Wasatch Front Regional Council (WFRC). (2015). Regional Transportation Plan: 2015-2040. Salt Lake City, UT: WFRC.

Wasatch Front Regional Council (WFRC). (n.d.). Wasatch Choices 2040: A Four County Land-Use and Transportation Vision. Salt Lake City, UT: Envision Utah.

Weiner, E. (1999). Urban Transportation Planning in the United States: An Historical Overview (2 ${ }^{\text {nd }}$ Ed.). New York: Praeger.

Wolf, J. (1995). This Poll Says Utahns Favor Wilderness Protection. Salt Lake Tribune, May 19, 1995, B1.

Wolf, J.F. \& Farquhar, M.D. (2005). Assessing Progress: The State of Metropolitan Planning Organizations under ISTEA and TEA-21. International Journal of Public Administration 28(13-14): 1057-1079.

Wolf, J.F. \& Fenwick, M. (2003). How Metropolitan Planning Organizations Incorporate Land-Use Issues in Regional Transportation Planning. State and Local Government Review. Vol. 35, No. 2 (Spring 2003): 123-31.

Yan, J. (2013). Rousing the Sleeping Giant: Administrative Enforcement of Title VI and New Routes to Equity in Transit Planning. California Law Review 110: 1131-1183. 


\section{APPENDIX A: PLAN SCORING METHODS}

\section{Implementation Rating System}

The implementation rating system is used to measure the extent to which local planning documents are implementing centers concepts. After reviewing each instance where a planning term is mentioned (e.g. urban center, neighborhood center, etc.) action-oriented instances of that term were recorded for further review. Recorded data was then used to score each planning term on a $0-3$ scale where a 3 is the strongest level of implementation.

To do this we looked at three types of planning terms:

- Urban Center Related Terms

- Plan \& Program Terms

- Agency Terms

Plan review and recording of 'urban center related terms' and 'plan \& program terms' followed a common procedure. An implementation score was assigned to each search term using the following guidelines:

- $\quad$ No Implementation (Score of 0): Term not mentioned, term mentioned but not in reference to metropolitan concept, or term mentioned but without any implementation.

- Weak Implementation (Score of 1): Implementation of term mentioned infrequently, only using general language, and in places with low visibility.

- Medium Implementation (Score of 2): Implementation of term mentioned but either in general language or in places with low visibility.

- $\quad$ Strong Implementation (Score of 3): Implementation of term mentioned frequently and in specific terms which are highly visible within the plan.

'Agency Terms' followed the same search procedure but scoring took place differently. An implementation score was assigned to each search term using the following guidelines:

- No partnership/ coordination (Score of 0): No mention of partnership/ coordination

- Weak partnership/ coordination (Score of 1): Partnership/ coordination with agency mentioned infrequently, only using general language, and in places with low visibility. Includes references to partnership/ coordination, which do not relate to centers.

- Medium partnership/ coordination (Score of 2): Partnership/ coordination mentioned but either in general language or in places with low visibility. Partnership/ coordination relates to centers.

- Strong partnership/ coordination (Score of 3): Partnership/ coordination mentioned frequently and in specific terms which are highly visible within the plan. Partnership coordination must relate directly to centers.

Three primary benchmarks were used to determine the implementation score each term receives -(1) specificity of language, (2) visibility, and (3) frequency. A combination of these three 
factors were used to formulate each search term's implementation score. See figures below for detailed information on how each piece of criteria was evaluated.

\section{Figure A-1: Specificity of Implementation Language}

\begin{tabular}{|l|l|}
\hline Rating & Example Language \\
\hline General Language & $\begin{array}{l}\text { New regional centers should be designed as transit destinations and to encourage } \\
\text { pedestrian use --1998 Aurora Comprehensive Plan, page } 100 \text { (Search term "Regional } \\
\text { Center") }\end{array}$ \\
\hline Intermediate Language & $\begin{array}{l}\text { Reserve Land for Future Regional Employment Centers --2012 Thornton } \\
\text { Comprehensive Plan, page 112 and 113 (Search term "Employment Center") }\end{array}$ \\
\hline Specific Language & $\begin{array}{l}\text { Produce or maintain plans for each major center and corridor addressing land use, } \\
\text { design, and recommended actions. Recommendations should be based on an } \\
\text { evaluation of the full range of possible tools, including re-zonings, financial incentives, a } \\
\text { full range of transportation options, public open space and plazas, and structured } \\
\text { parking --2009 Aurora Comprehensive Plan, page 184 (Search Term "Urban Center") }\end{array}$ \\
\hline
\end{tabular}

Figure A-2: Visibility of Implementation Language

\begin{tabular}{|c|c|}
\hline Rating & Visibility Criteria \\
\hline Low Visibility & $\begin{array}{l}\text { - Text does not stand out from the rest of the document } \\
\text { - } \quad \text { May be found in long paragraphs or deep within a section of the plan } \\
\text { - } \quad \text { There is a high likelihood that a casual reader would miss the passage of text }\end{array}$ \\
\hline Medium Visibility & $\begin{array}{l}\text { - Text is low in the document hierarchy } \\
\text { - Text fits the context document without being lost or standing out prominently }\end{array}$ \\
\hline High Visibility & $\begin{array}{l}\text { - } \quad \text { Text which draws the eye and is prominent within the document } \\
\text { - } \quad \text { It is unlikely that a casual reader would miss the passage of text } \\
\text { - } \quad \text { Highlighted or bolded text which stands out from the rest of the document } \\
\text { - } \quad \text { Text which is a part of a defined list of goals, objectives, strategies, etc. }\end{array}$ \\
\hline
\end{tabular}

\section{Figure A-3: Frequency of Implementation Language}

\begin{tabular}{|l|l|}
\hline Rating & Frequency \\
\hline Low Frequency & $\begin{array}{l}\text { Implementation of term mentioned sporadically at best (less than five times throughout } \\
\text { document) }\end{array}$ \\
\hline Medium Frequency & $\begin{array}{l}\text { Implementation of term mentioned periodically (roughly 5-10 times throughout the } \\
\text { document) }\end{array}$ \\
\hline High Frequency & $\begin{array}{l}\text { Implementation of term mentioned repeatedly (More than 10 times throughout } \\
\text { document) }\end{array}$ \\
\hline
\end{tabular}


Figure A-4: Plan Review Search Terms -Denver

\begin{tabular}{|l|l|}
\hline Category & Terms \\
\hline \multirow{5}{*}{ Urban Center Related Terms } & Regional Center \\
\cline { 2 - 2 } & Community Center \\
\cline { 2 - 2 } & Neighborhood Center \\
\cline { 2 - 2 } & Urban Center \\
\cline { 2 - 2 } & Employment Center \\
\cline { 2 - 2 } & Regional Activity Center \\
\cline { 2 - 2 } & Community Activity Center \\
\cline { 2 - 2 } & Neighborhood Activity Center \\
\cline { 2 - 2 } & Urban Activity Center \\
\cline { 2 - 2 } & Multi-Purpose Center \\
\cline { 2 - 2 } & Transit Oriented Development (TOD) \\
\hline \multirow{3}{*}{ Plans \& Program Terms } & FasTracks \\
\cline { 2 - 2 } & Metro Vision \\
\hline \multirow{2}{*}{ Agency Terms } & DRCOG \\
\cline { 2 - 2 } & Regional Transportation District (RTD) \\
\hline
\end{tabular}

Figure A-5: Plan Review Search Terms -Salt Lake City

\begin{tabular}{|l|l|}
\hline Category & Terms \\
\hline \multirow{5}{*}{ Urban Center Related Terms } & Metropolitan Center \\
\cline { 2 - 2 } & Urban Center \\
\cline { 2 - 2 } & Town Center \\
\cline { 2 - 2 } & Station Community ${ }^{10}$ \\
\cline { 2 - 2 } & Main Street Community10 \\
\cline { 2 - 2 } & Boulevard Community10 \\
\cline { 2 - 2 } & Employment/ Job Center \\
\cline { 2 - 2 } & Growth Center \\
\cline { 2 - 2 } & Transit Oriented Development (TOD) \\
\hline \multirow{5}{*}{ Plans \& Program Terms } & Wasatch Choice for 2040 \\
\cline { 2 - 2 } & Envision Utah \\
\cline { 2 - 2 } & TRAX \\
\cline { 2 - 2 } & FrontRunner \\
\hline \multirow{5}{*}{ Agency Terms } & Wasatch Front Regional Council (WFRC) \\
\cline { 2 - 2 } & Mountainland Association of Government \\
\hline
\end{tabular}

\footnotetext{
${ }^{10}$ More open-ended search process. Captured instances where reference was less precise than for typical terms.
} 


\section{APPENDIX B: GIS METHODS}

\section{A.1 DEMOGRAPHIC AND LAND USE METRICS}

This section describes methods for obtaining center level data for demographic, land use and some transportation metrics using Census data. Methodology was modeled after the TOD Database. See: See: http://toddata.cnt.org/user-guide.php.

\section{A.1.1 Data Needs}

- Center boundaries

- Census Block Group Shapefiles: 2000 and 2010 (TIGER/Line)

- Attribute Tables (Social Explorer)

o 2010 Census: T1, T2, T58, T64, T68, T71, T73, T64, T69

o 2008-2012 ACS: T17, T21, T57, T101, T129, B08301, B19001,B19013, B25035, B25044, B25046

o 2000 Census: T1, T3, T4, T20, T26, T69, T92, T93, T96, T156, T157, T160, T162, T195, T196, P33, H44, H46

\section{A.1.2 Pre-Processing}

o Clean up Social Explorer tables in Excel and rename fields

o Convert .csv to .dbt and create a string field for FIPS code to join to string field in shapefile

o Select all block groups that intersect with centers and export a new shapefile (to improve processing speed.

\section{A.1.3 Apportionment}

\section{In GIS:}

o Compute area of block groups (

o For each individual center (must be done individually because some centers overlap):

o Clip block groups to urban center

o Compute area of clipped shapefiles (one shapefile for each Center)

\section{In Excel:}

o Calculate percent of block group area that lies within urban center

o Apply share of block group area percent to each category for each census block group and sum up proportions to obtain totals for each Center.

o Some values (income and year built) must be normalized to number house households or housing units.

\section{A.2 TRANSPORTATION NETWORK METRICS}

This section describes methods for obtaining center level data for transportation network characteristics.

\section{A.2.1 Data Needs:}

- Rail Stations 
- Bus Stations

- Bus Routes

- Road Network

- Center boundaries

\section{A.2.2 Pre-Processing}

- Buffer Rail Stations to create $1 / 2$ mile buffers (TODs)

- Clip road and bus network to center boundaries

\section{A.2.3 Individual Metrics}

\section{A.2.3.1 Cul-de-sacs}

- Run the "Feature Vertices to Points" Tool (Located in Data Management Tools --> Features) and select "Dangle" as the point type.

- Then, use "Select by location" to pick up all lines that touch those dangle points.

- Input is Network

- Clip Danges to buffers.

\section{A.2.3.2 Cul-de-sac Ratio}

- Formula = \# of cul-de-sacs/ 502.654 acres

\section{A.2.3.3 Road Length}

- Give your buffers a unique name attribute (rather than just using the OID, which you could do, but having a (short) name to follow will make it easier).

- Now you need your roads split at all Center boundaries, or at least some way to determine which segments (and portions) are in which buffer.

- Use Intersect or Identity (requires an Advanced license) on your roads and buffer layer. The result should be a road layer that is cut up into segments wherever a road crosses a buffer line. A new attribute will be added to the road segments with your buffer names. If a road lies in more than one buffer it will be duplicated so that there are two records for the segment, one with each name. Intersect will give you only the segments in buffers (maybe preferable?), whereas Identity will give you all the roads - those not in buffers will have no name attribute value.

- Compute Total Length

o The simplest would be to open the attribute table of your new road layer, right-click on the name field, and choose Summarize. Make sure the name field is selected as your Summarize field, then in the lower box find the Shape_Length field, click the plus next to it and check the box for sum. The resulting output should be a table with the total length of all road segments by buffer name (make sure you have no records selected or clear that check box). The units will be in CRS units, so you may need to convert to miles or feet or kilometers or whatever your desired output unit is.

o You can also use the Summary Statistics tool. You will put the length field in as your statistic field with a type of sum, and then you'll add name field as a 
case fields. This tool would let you incorporate it into a model if needed (Summarize is only available through the GUI).

- NOTE: Have street lengths in ArcGIS table but do not know units. Is it units of the source's projection?

\section{A.2.3.1 Average Block Length}

- Using Center attributes (spatial joined to each segment), use summarize to compute average length 
Transportation Research and Education Center

Portland State University

1900 S.W. Fourth Ave., Suite 175

Portland, OR 97201 